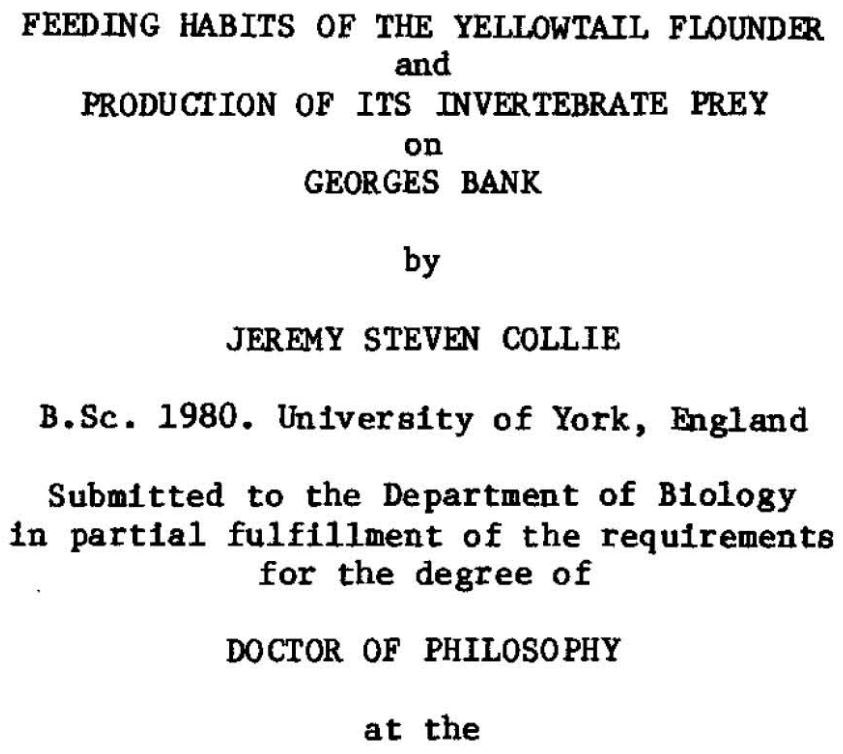

The author hereby grants M.I.T. and W.H.O.I. permission to reproduce and distribute coples of this thesis in whole or in part.

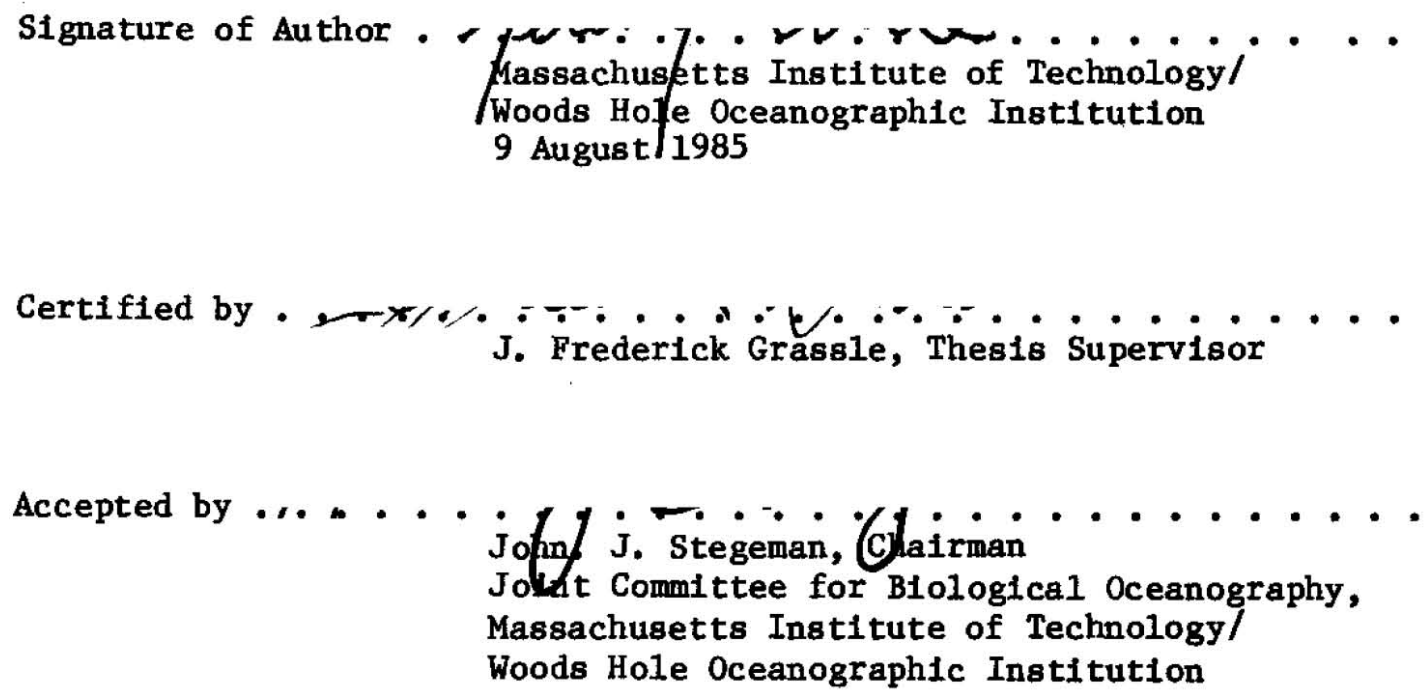


In any study of evolutionary ecology, food relations appear as one of the most important aspects of the system of Inanimate nature. There is quite obviously much more to living communities than the raw dictum "eat or be eaten", but in order to understand the higher intricasies of any ecological system, It is most easy to start from this crudely simple point of view.

G. Evelyn Hutchinson, 1959 Homage to Santa Rosalia or Why are there so many kinds of animals? American Naturalist 93: 145-159 
TABLE OF CONTENTS

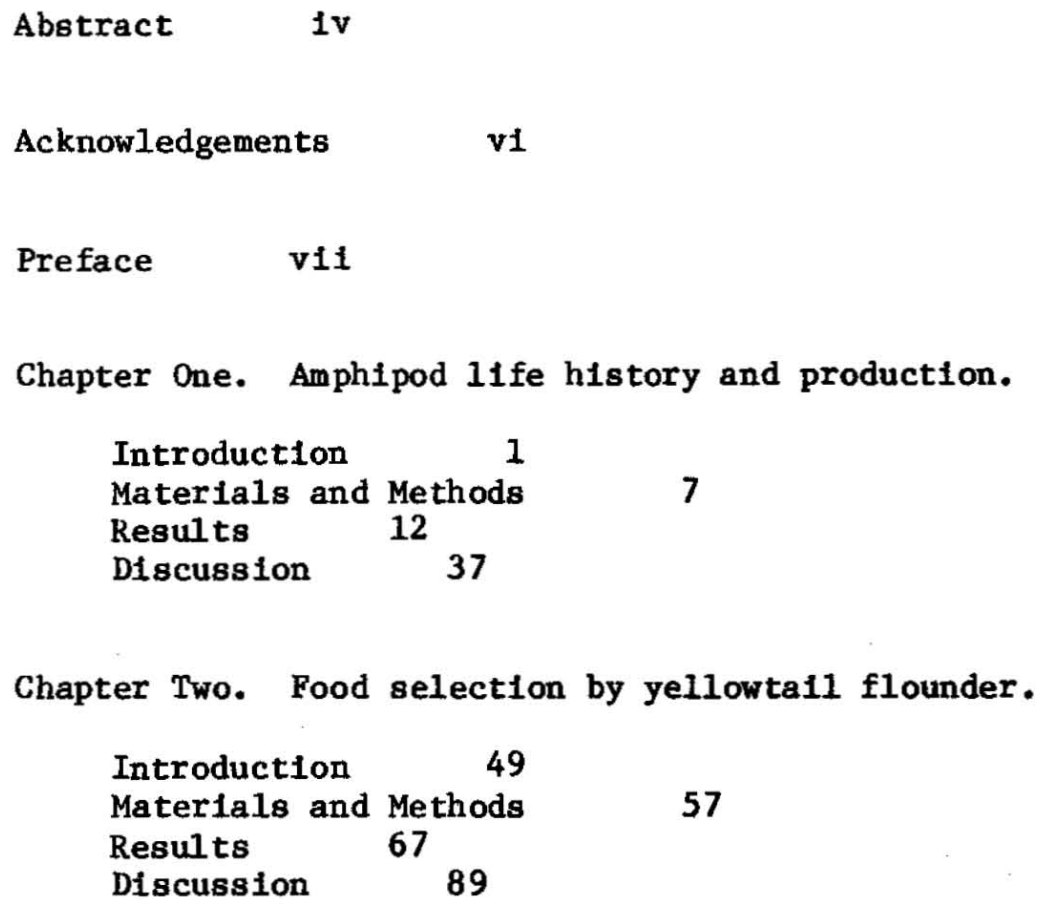

Chapter One. Amphipod life history and production.

Chapter Two. Food selection by yellowtall flounder.

Chapter Three. Rate of food consumption by yellowtall flounder.

\begin{tabular}{llr} 
Introduction & & 97 \\
Methods & 105 \\
Results & 110 \\
Discussion & \multicolumn{2}{c}{122}
\end{tabular}

Conclusions $\quad 131$

References $\quad 135$

Appendix A. Amphipod production calculations 143

Appendix B. Yellowtall flounder stomach contents data 155 Appendix C. Chone Infundibuliformis production calculation 164 
FEEDING HABITS OF THE YELLOWTAIL FLOUNDER
and

PRODUCTION OF ITS INVERTEBRATE PREY

on

GEORGES BANK

by

\title{
JEREMY STEVEN COLLIE
}

\author{
Submitted to the Department of Blology \\ on 9 August 1985 in partial fulfillment of the \\ requirements for the degree of Doctor of Philosophy \\ in B1ological Oceanography
}

\begin{abstract}
As part of the Georges Bank Benthic Infauna Monitoring Program, size-frequency analysis was used to study the life history and production of three benthic amphipod species: Ampelisca agassiz1, Unciola inermis and Ericthonius fasciatus. Abundant over large areas of Georges Bank, these amphipods are important prey of yellowtail flounder. From benthic grab samples collected quarterly during 1981 to 1983, over 200 individuals of each specles were measured for each sampling date. The computer program NORMSEP separated the length-frequency distributions into cohorts. Growth and mortality rates were determined by following cohorts through time; production was calculated as the sum of growth increments. Differences in the population dynamics of the three species were exemplified by annual production-to-biomass ratios $(P / B)$. E. fasciatus had the highest $P / B(2.8$ to 4.1), followed by U. inermis (1.3 to 2.7 ) and A. agassizi (1.3 to 1.4). These results, the first direct production estimates for benthic macrofaunal species on Georges Bank, are compared to production estimates for other marine amphipod species. Amphipod production rates on Georges Bank are as high as production rates of related near-shore specles with similar life-spans.

The Northeast Fisheries Center sampled yellowtall flounder stomachs at three sites on four quarterly dates from August 1982 to May 1983. As closely as possible, stomach sampling colncided with the dates and locations of benthic monitoring to enable direct comparison between ingested and avaliable food. Stomach contents were sorted and weighed and important prey species were measured. Yellowtall flounder feed mainly on benthic macrofauna; amphipods and polychaetes are the most important prey groups. Although the diet composition varied among stations and dates, in each case a few prey species constituted the bulk of the diet. Selection Indices were calculated to compare the species composition of the stomach contents to that of the benthic macrofauna. Food selection by yellowtall flounder is explained on the basis of prey life history and prey size. The species- and size-selection indices account for most of the variability in diet composition. A log-normal curve was fit, by least squares, to the size-selection indices; according to this fit, the optimum prey weight for yellowtail flounder is $21 \mathrm{mg}$.
\end{abstract}


The rate of food consumption by yellowtail flounder was calculated by two methods. The bioenergetic method sums the food required to satisfy the energetic requirements of the fish. The second method is based on the weight of stomach contents and the rate of food evacuation from the stomach. The bioenergetic method gave consistently higher results ( 1.4 to $1.6 \mathrm{~kg} \mathrm{fish}-1 \mathrm{yr}^{-1}$ ) than the stomach-content method $\left(0.5\right.$ to $\left.0.8 \mathrm{~kg} \mathrm{fish}-1 \mathrm{yr}^{-1}\right)$. Yellowtall flounder abundance was estimated by a method that uses the commerclal catch data to standardize the survey, relative-abundance index. These abundance estimates were divided by the appropriate areas to obtain yellowtall flounder density estimates for fall 1982 of 20.0 and 41.3 fish per hectare for Georges Bank and Southern New England, respectively. Consumption rates per fish were multiplied by flounder density to obtain estfimates of consumption per unit area, which range from 1.2 to $6.3 \mathrm{gww} \mathrm{m}^{-2} \mathrm{yr}^{-1}$. Annual production of six important prey species was calculated. Yellowtall flounder consumption as a percentage of prey production was 6 to $12 \%, 2$ to $5 \%$, and 1 to $3 \%$, for the amphipods Unciola Inermis, Ericthonius fasciatus and Ampelisca agassizi, respectively; 11 to $34 \%$ and 7 to $21 \%$ for the polychaetes Chone Infundibuliformis and Nephtys Incisa, respectively; and less than 1\% for the sand dollar, Echtnarachnius parma.

Thesis Supervisor: Dr. J. Frederick Grassle, Sentor Sclentist, Woods Hole Oceanographic Institution 
Because of the broad scope of this project, I could not have completed it without the help and cooperation of many people. First and foremost I thank my major advisor, Dr. Fred Grassle; without his help in the planning stages, this project would not have gotten underway. Secondly, I thank my co-advisor, Dr. Mike Sissenwine, for taking me under his wing when I first arrived in Woods Hole.

I an grateful to all my thesis committee members for advice in their own particular specialities: Dr. J.F. Grassle (WHOI) for his extensive knowledge of the benthos; Dr. M.P. Sissenwine (NEFC), whose own dissertation was on yellowtall flounder; Dr. J.H. Steele (WHOI) for his interest in food chains and predator-prey Interactions; Dr. R.H. Backus (WHOI), editor of the forthcoming atlas on Georges Bank; and Dr. Wr. DuMouchel (MIT) in statistics.

Special thanks are due to Dr. M.D. Grossleln of the Northeast Fisheries Center, Woods Hole, for coordinating the fish-stomach sampling. Ray Bowman and Bill Milchaels helped collect the stomachs. I thank Dr. N. Maclolek-Blake of Battelle New England Mar1ne Research Laboratory for her support in making samples and data available to me. I thank Debble McGrath, Ellie Baptiste and all the other people at Battelle who sorted and identified samples.

To all the benthons in Redfleld basement I am grateful: to Linda Morse-Porteous, Brian Dade and Howard Sanders for Insightful discussions, to Susan Brown-Ieger who taught me how to tell the girls from the boys (amphipods) and to Rose Petrecca who organized the benthic sampling. Carla Curran analyzed the sand dollar samples as a Sumer Fellow and analyzed the Station 5-28 amphipods as a Research Assistant in the fall of 1984; I thank her for her enthuslastic help.

Peggy Dimmock typed the appendices. F1gures 1-3 through 1-6, 1-8 and 1-9 are herein reproduced from Collie (1985) with permission of the publisher, Inter-research. Figures $3-3$ and $3-4$ are redrawn from Collie and Sissenwine (1983).

This project was funded by contract no. 14-12-0001-29192 from the Minerals Management Service, U.S. Department of the Interior, Washington D.C. I was supported by the W.H.O.I. Eduction Office during part of my time in Woods Hole. 


\section{PREFACE}

Continental shelves constitute only $10 \%$ of the ocean floor, yet over half the world catch of marine flsh 18 produced in shelf waters. The high productivity of continental shelves is attributable to their shallow depths, which concentrate flsh for economic harvesting and allow greater nutrlent recycling with the overlying water column (Walsh 1981). The importance to humans of the continental shelves is underscored by recent o11 and gas exploration and the declaration of 200 nautical mile exclustve economic zones by many coastal nations (see Oceanus 27(4)). Oceanographic research on continental shelves is complicated by the great distances involved and the need for ocean-going ships. Direct experimentation is difficult because any instrument strong enough to withstand the currents and waves is 11kely to introduce experimental artifacts.

Georges Bank is part of the continental shelf off the eastern coast of North America. The waters over this shallow submarine plateau are known to support high production rates of phytoplankton and fish (Backus, in press, Chpts. 21 and 31). However, the energy pathways between phytoplankton and fish are not well understood. The Georges Bank energy budget (S1ssenwine et al. 1982) provides a useful framework for studying the food web and points out gaps in our measurements of standing stocks and flux rates. In particular, 11ttle is known about the coupling of pelagic and benthic processes: how the energy from primary production is transformed into the benthic Invertebrates that, In turn, are food for many spectes of demersal flsh.

Walsh (1981) presented a preliminary carbon budget for the northeastern continental shelf from Georges Bank to Cape Hatteras. of 
the total primary production at mid-shelf (about $340 \mathrm{gC} \mathrm{m}^{-2} \mathrm{yr}^{-1}$ ), a large proportion apparently transfers to the sea bottom as phytodetritus $\left(200 \mathrm{gC} \mathrm{m}^{-2} \mathrm{yr}^{-1}\right)$ and fecal pellets $\left(40 \mathrm{gC} \mathrm{m}^{-2} \mathrm{yr}^{-1}\right)$.

Ut1lization of organic carbon by benthic Infauna, as estimated from benthic respiration and production, accounts for about $50 \mathrm{gC} \mathrm{m}^{-2}$ $\mathrm{yr}^{-1}$. The remaining $190 \mathrm{gC} \mathrm{m}^{-2} \mathrm{yr}^{-1}$ lost from the water colum is elther burled or exported, or it must be utilized by organisms not considered in the carbon budget (e.g. microbial respiration). Walsh probably overestimated primary production by about 50\% (G.T. Rowe, personal communication), but even so, benthic respiration would only account for one third of the carbon reaching the bottom.

This thesis concentrates on one segment of the Georges Bank food web: production of benthic invertebrates and predation on these invertebrates by the yellowtail flounder. I approached this topic from a number of perspectives: as a study of amphipod population dynamics, a study of food selection by yellowtall flounder, a quantification of part of the Georges Bank food web, and finally as a study of the Interaction between predator and prey populations. In this thesis I address the following questions: What are the rates of amphipod production? on what basls do yellowtall flounder choose thelr prey? How do flounder respond to changes in abundance of their preferred prey? What is the rate of food consumption by yellowtall flounder? Does the rate of prey production 1imit flounder feeding? Conversely, is fish predation a Bignificant source of mortality to the prey populations? 
CHAPTER ONE

AMPHIPOD LIFE HISTORY AND PRODUCTION

\section{INTRODUCTION}

The earliest reported benthic samples from Georges Bank were the dredge collections made by Smith and Harger (1874). More recently, between 1957 and 1964, the Benthic Dynamics Group of the Northeast Fisheries Center conducted an extensive benthic survey of the U.S. east coast (Wigley 1968). On Georges Bank, samples were collected from more than 150 evenly-distributed stations. Dickinson and Wigley (1981) analyzed the amphipods from these samples and documented the distribution of gammaridean amphipods on Georges Bank. These early studies established the taxonomy and distribution of benthic specles; 11ttle information concerning life history was obtained.

In 1977 the New England Outer Continental Shelf Benchmark Program was conducted to obtain baseline data on benthic community structure prior to exploratory ofl and gas drilling. Forty-two stations on Georges Bank and adjacent areas were sampled quarterly. Data from all four seasons are ava1lable from only 11 of these stations (Michael et al. 1983). This report described the faunal composition of these sites over one year, but did not provide any information on the life histories of dominant species. Nine of the 11 Benchmark stations were later adopted In the Georges Bank Benthic Infauna Monitoring Program (GBMP).

During a two-year perlod, from May 1980 to July 1982, benthic samples were collected at three sites in conjunction with U.S. Geological Survey studies of sediment transport dynamics; two of these sites were adopted as regional stations in the GBMP. Together, the USGS and GBMP 


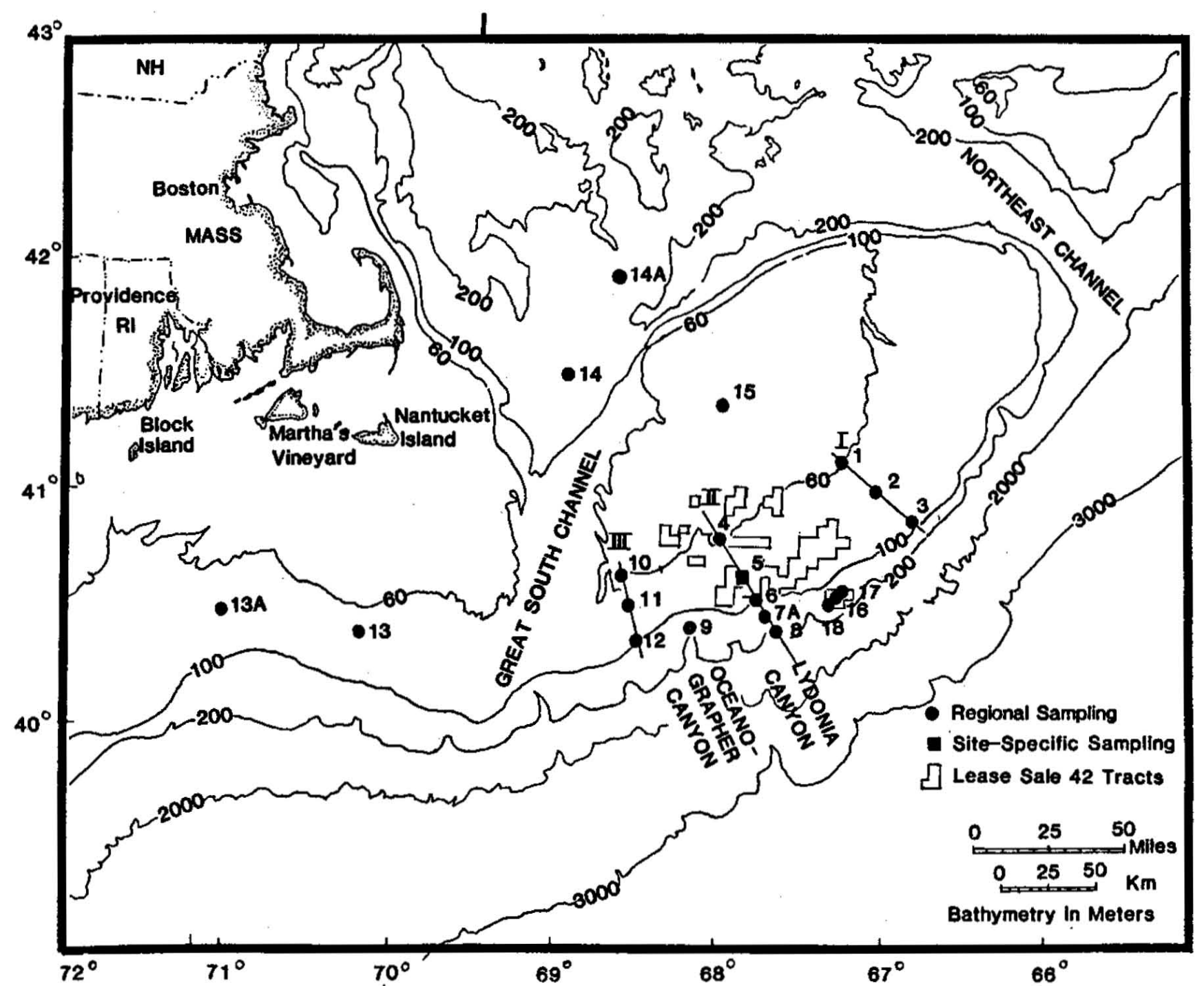

Figure 1-1. Locations of stations sampled by the Georges Bank Benthic Infauna Monitoring Program. 
samples provide a four-year time series of benthic spectes abundance on Georges Bank.

The Georges Bank Benth1c Infauna Monitoring Program (GBMP) was designed to trace discharges from ofl and gas exploration and to determine their effects on benthic species and communities (Battelle and WHOI 1985). Quarterly sampling was conducted from July 1981 to June 1984. On each date, 18 regional (Fig. 1-1) and 29 site-specific stations were sampled. The site-specific stations were located in an array centered at Regional Station 5 (Fig. 1-2). Repeated sampling during the GBMP provided an opportunity to study the life history of dominant benthic spectes on Georges Bank.

Steimle (in press) used the biomass data from the 1957-to-1964 and 1977 benthic surveys to estimate macrofaunal production on Georges Bank. He estimated production by partitioning the blomass data among the major taxa and applying a representative production-to-biomass ratio ( $P / B)$ to each taxon. The amphipod production estimates I present in this chapter are the first direct estimates of macrofaunal production on Georges Bank. Many, but not all, of the results in this chapter have been presented in Collie (1985) and in Collie and Curran (1985); this chapter Includes additional amphipod life-history data.

In this chapter I am concerned with the life historles and production rates of three benthic, gammaridean amphipod species: Ampelisca agassizi Judd (Ampeliscidae), Unctola Inermis Shoemaker (Aoridae) and Ericthonlus fasciatus Stimson (Ischyroceridae). All three species are tubicolous, subtidal and widely distributed (Bousfield 1973), but 11ttle is known about their 11fe cycles. The specles called Ericthonius fasciatus in this thesis has been called E. rubricornis by Bousfleld (1973) and other authors. However, the genus Ericthonius was 


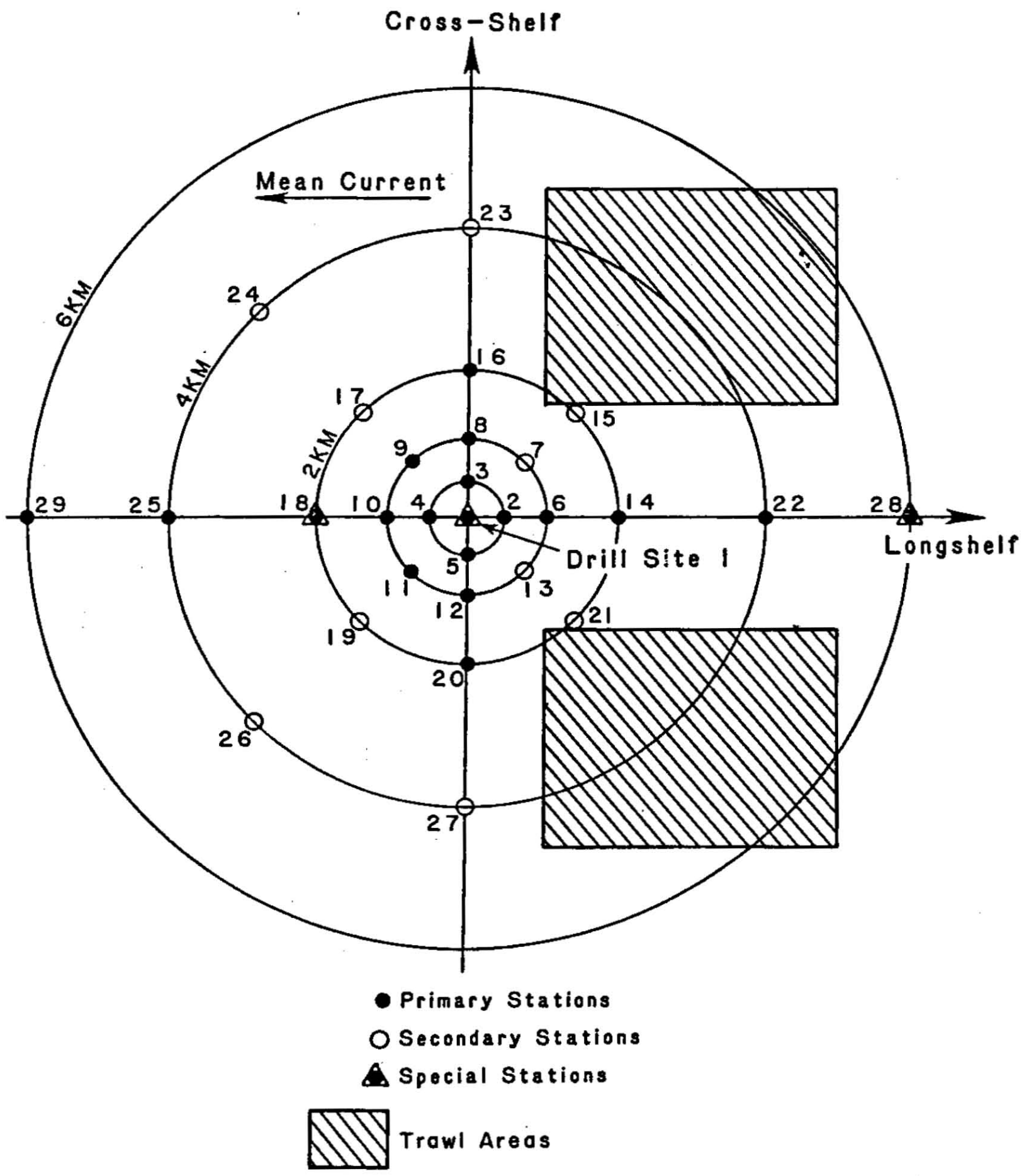

Figure 1-2. Site-specific stations and fish-trawling areas centered at Regional Station 5 . 
recently revised by Myers and McGrath (1984), and since the Ericthonius I studied fit the description of $\underline{E}$. fasciatus by Myers and McGrath, the more recent appellation will be followed. Ampelisca agassizi lives along both American coasts; in the northwestern Atlantic it has been collected from Nova Scotia to the Caribbean at depths of 5 to $450 \mathrm{~m}$ (Mills 1967a). On Georges Bank, A. agassizi has been found in high densities between 60 and $170 \mathrm{~m}$ (Dickinson and Wigley 1981). Unciola Inermis is distributed along the North American Atlantic coast from Labrador to North Carolina at depths of 0 to $200 \mathrm{~m}$ (Shoemaker 1945). U. inermis inhabits the perimeter of Georges Bank between 57 and 192 m (Dickinson and Wigley 1981). Ericthonius fasciatus has an amphi-Atlantic distribution; along the North American coast it has been collected from Labrador to Cape Hatteras at depths of 0

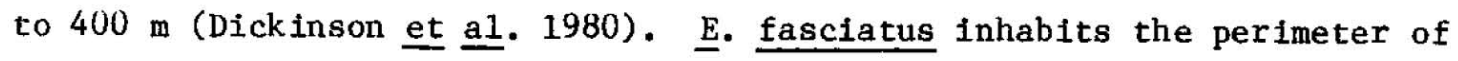
Georges Bank between 40 and $192 \mathrm{~m}$ (Dickinson and Wigley 1981).

In benthic samples collected during the three-year course of the GBMP, Ampelisca agassiz1 was found to be the most numerous macrofaunal species when a grand sum was taken of the species counts in all replicates, from all regional stations, from all sampling dates. Ericthonius fasciatus was fourth and Unciola Inermis was the $21^{\text {st }}$ most numerous out of 959 enumerated species. All three amphipod species were found in large numbers in the stomachs of several demersal fish species collected off the U.S. east coast by Bowman and Michaels (1984). These amphipods are good candidates for study because their recruitment is synchronous, which allows cohorts to be identified in the length-frequency distrfbutions. Because female amphipods brood their young, there are no pelagic larvae and all life stages can be collected by benthic samplers. Amphipods don't produce growth rings; therefore I 
used size as a surrogate measure of age. The method I use to estimate production depends on being able to identify cohorts and to follow the fate of these cohorts through time.

Four commonly used methods of computing cohort production are increment surmation, removal summation, instantaneous growth and the Allen curve. Each of these may be used either in instantaneous, exponential form or in discrete, linear form. The instantaneous form applies when growth and mortality rates are constant and biomass changes exponentially. Gillespie and Benke (1979) showed that under these conditions, the four methods are exactly equivalent. In discrete, linear form, the increment-sumation and removal-summation methods are exactly equivalent, but the instantaneous-growth and Allen-curve methods merely appoximate the first two.

Jensen (1919) first proposed a rationale for cohort-based production estimates. Sanders (1956) modifled Jensen's Inaccurate method into what is known now as the removal-summation method. A good explanation of how the increment-summation and removal-summation methods are applied to fleld data is given by Crisp (1984). 
MATERIALS AND METHODS

This analysis is based on samples collected quarterly during the first two years of the GBMP (July 1981 to July 1983). At each station, on each sampling date, six replicate, $0.04-\mathrm{m}^{2}$, modified van Veen grab samples were collected, sleved, and preserved. All replicates were taken within $100 \mathrm{~m}$ of the station coordinates. Workers at Battelle Marine Research Laboratory resleved each sample on a 0.3-mm screen, then sorted, enumerated and 1dentified to species the organisms recovered. Size selectivity should not be a problem here because a $0.3-\mathrm{mm}$ sieve retains all 11fe stages including dislodged eggs.

I chose Regional Stations 5 and 13 for this study because fish stomachs also were collected at these sites. Station 5 at $84 \mathrm{~m}$ depth is characterized by medium-to-coarse sand. At this site, Unciola Inermis and Ericthonius fasclatus are among the five most numerous macrofaunal species. Samples of these two species were analyzed from Site-spectfic Station 5-1 (July 1981 to July 1983) and from Site-specific Station 5-28 (July 1982 to July 1983). The samples from Station 5-28 were analyzed to compare production of the same species at two adjacent sites (see Fig. 1-2 for site-specific station locations). I analyzed Ampelisca agassizi from Station 13, where it is, numerlcally, one of the top five species. The sediments at Station 13 , located at $69 \mathrm{~m}$ in the area south of Nantucket known locally as "the mudpatch", are predominantly very fine sand, silt and clay. The sediments and fauna at these sites are described more completely in Battelle and WHOI (1985).

I measured the amphipods with a digitizer coupled to a mlcrocomputer. (Carla Curran analyzed the Station 5-28 samples.) Each anlmal was measured from the tip of 1 ts rostrum to the base of 1 ts telson 
(Bousfleld 1973; see arrows in Fig. 1-10) by tracing a camera lucida projection with the digitizer wand. An internal calibration factor allowed Immediate conversion from digltizer units to length in millimeters. Sample sizes permitting, at least 200 amphipods of each specles from each sampling date were measured. Replicates were digitized until the replicate containing the $200^{\text {th }}$ animal was completed, or until all replicates were measured, whichever came first. For cases in which not all replicates were measured, each frequency was scaled to determine the expected number of amphipods of that size, had every individual been measured.

In addition to length, I measured a number of life-history parameters. For most of the samples, I classifled adult (larger than 5 $\mathrm{mm}$ ) amphipods by sex. I used the G-test to test the sex ratios against a 1:1 ratio and against the sex ratio of amphipods found in yellowtail flounder stomachs (see Chapter 2 for detalls of fish-stomach analysis). The eggs of these amphipod specles develop and hatch in the marsupium formed by the females oostegites (brood plates). I further classified adult females into three categorles: ovigerous females, females with setose oostegites, and females with developing oostegites. Number of embryos in the brood pouch was recorded for each ovigerous female. Using microscissors, I dissected a number of females to ascertain the state of ovary development. Parasites were sketched and their occurrence recorded.

I used modal analysis to Identify cohorts in the length-frequency data. The computer program NORMSEP, written in FORTRAN by Tomlinson (1971) using Hasselblad's (1966) algorithm, separates length-frequency sampling distributions into component normal distributions. In essence, this is a computer-equivalent of the probability-paper method (Harding 1949). NORMSEP uses a maximum-1ikelihood function to minimize the 
difference between observed and expected frequency distributions, and a chi-square statistic measures the goodness of fit. NORMSEP calculates mean length, standard deviation, and number of individuals in each component distribution.

Owing to the minimum number of measurements required for a length-frequency distribution, and the maximum number of amphipods it was practical to measure from each sample, I was unable to generate replicate length-frequency distributions. I assumed, therefore, that a sample size of 200 represented the true size distribution of the entire population. To test the validity of this assumption, I performed a bootstrap analysis of the Unciola Inermis s1ze-frequency data from July 1981 at Station 5-1. The bootstrap is used to indicate the sensitivity of my method of size-frequency analysis to sampling varlability.

By sampling with replacement from the observed distribution, I produced 20 sets of simulated length-frequency data. The FORTRAN function RAN generates psuedo-random decimals that are uniformly distributed from 0 to 1 . To get seed numbers for the different trials I took the first 20 extensions from the WHOI telephone directory, written in reverse order as negative decimals. This ensured a different sequence of random numbers in each trial.

The number of random numbers generated in each trial (249) equalled the number of length measurements made on that sample. The observed length-frequency data were transformed to a cumulative frequency distribution from 0 to 1 . This distribution was used to place each random number in the appropriate length class. In this manner, I simulated 20 sets of length-frequency data, each similar to the observed distribution but differing by random variation. I applied the program NORMSEP to each length-frequency distribution in turn to estimate the 
parameters of the component modes; the means, variances and covariances of these bootstrap parameter estimates were calculated.

To eliminate potential preservation blas, I determined length-weight relationsh1ps for each specles using live animals collected in May 1983. To obtain live weights, I damp dried individual animals and weighed each to $0.01 \mathrm{mg}$ on a Mettler balance. Then after anaesthetizing w1th FINQUEL, I measured each animal with the digitizer. To describe the relationship between length (L) and weight (w) I fit, for each species, by linear regression, a line of the form,

$$
\log (w)=a+b \log (L)
$$

For groups of animals, each group with a total fresh weight of between 20 and $30 \mathrm{mg}$, I ascertained ash-free dry welght by drying the samples to constant weight at $60^{\circ} \mathrm{C}$ and combusting at $450^{\circ} \mathrm{C}$ for 5 hours.

To determine growth and mortality rates, I followed the mean length and numbers of each cohort through time. I converted mean length of the animals in a cohort to mean weight using the length-weight regressions. Equation 1.1 applies for individual animals but not for the mean of a length distribution. Because weight is a power function of length, the weight corresponding to the observed mean length underestimates the true mean welght by an amount dependent on the variance of length. Plenaar and Ricker (1968) provided formulae that approximate the true mean weight given that the length-weight relationship (Eq. 1.1) and variance of length $\left(s^{2}\right)$ are known. For the case in which 1 b 3 :

$$
\bar{w}=a\left(L^{b}+c L^{b-2} s^{2}\right)
$$


The values of $a$ and $b$ are as fitted to Eq. 1.1; the value of $c$, which depends on b, can be found in Table II of Plenaar and Ricker (1968).

I used the increment-summation method described by Crisp (1984) to calculate annual production. Production (P) of each cohort is the sum of weight increments over time $(t)$ according to:

$$
P=\sum_{t} \frac{N(t)+N(t+1)}{2}(\bar{w}(t+1)-\bar{w}(t))
$$

where $N(t)$ and $\bar{w}(t)$ axe, respectively, the number and mean weight of individuals in the cohort at time $t$. Annual production of a given species is the sum of each cohort's production over one year. 
RESULTS

Observed length-frequency distributions are plotted in F1gs. 1-3, 1-4, and 1-5. The frequencles are based on six replicate $0.04-\mathrm{m}^{2} \mathrm{grab}$ samples, giving a total area of $0.24 \mathrm{~m}^{2}$. White blocks in the histograms represent ovigerous females. The mean size of juveniles still in the marsupium was $1.8 \mathrm{~mm}$ for Ampelisca agassizi and $1.4 \mathrm{~mm}$ for both Unciola inermis and Ericthonius fasclatus; therefore peaks in the length-frequency distributions at these lengths correspond to newly released juveniles. Cohorts are named according to the year (and season) in which they were released.

Ampelisca agassizi at Station 13 (F1g. 1-3) appears to be a biennial species in that females of a given generation breed at age 1 and at least some survive to breed at age 2 . For example cohorts $80 \mathrm{~A}$ and $80 \mathrm{~B}$ had ovigerous females in November 1981 and again in July 1982, while cohort $81 \mathrm{~B}$ had ovigerous females in November 1982 and again in May 1983. The timing of reproduction varied from year to year. In 1981 ovigerous females were found only in November and recruitment of juveniles occurred in the late fall. Recrultment was delayed in 1981 because cohort 79 did not survive to breed for a second year. In 1982 the breeding season was advanced with ovigerous females present in July and November and recruitment in the late summer. The breeding season was even more advanced in 1983 with ovigerous females present in May and July. Recruitment of juventles had not occurred by July suggesting that either juveniles were released and lost from the sampling area or the development time of embryos is longer than 2 months. The minimum and maximum lengths of ovigerous females were 5.4 and $10.1 \mathrm{~mm}$, respectively. A length of $10 \mathrm{~mm}$ may be reached after the maximum life-span of 2 years. 


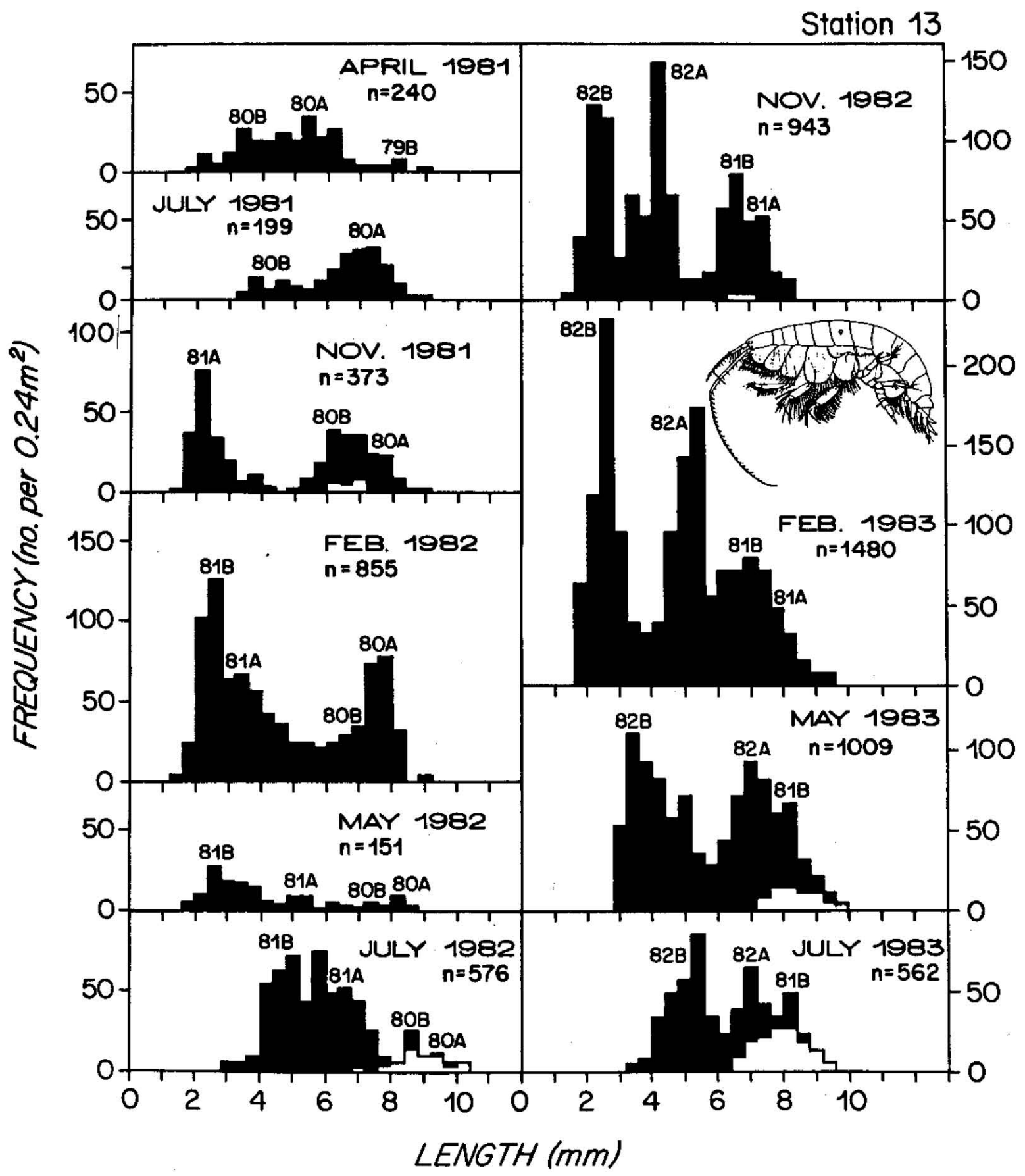

Figure 1-3. Length-frequency of Ampelisca agassizi at Station 13. White blocks in the histograms represent ovigerous females. From Collie (1985). 


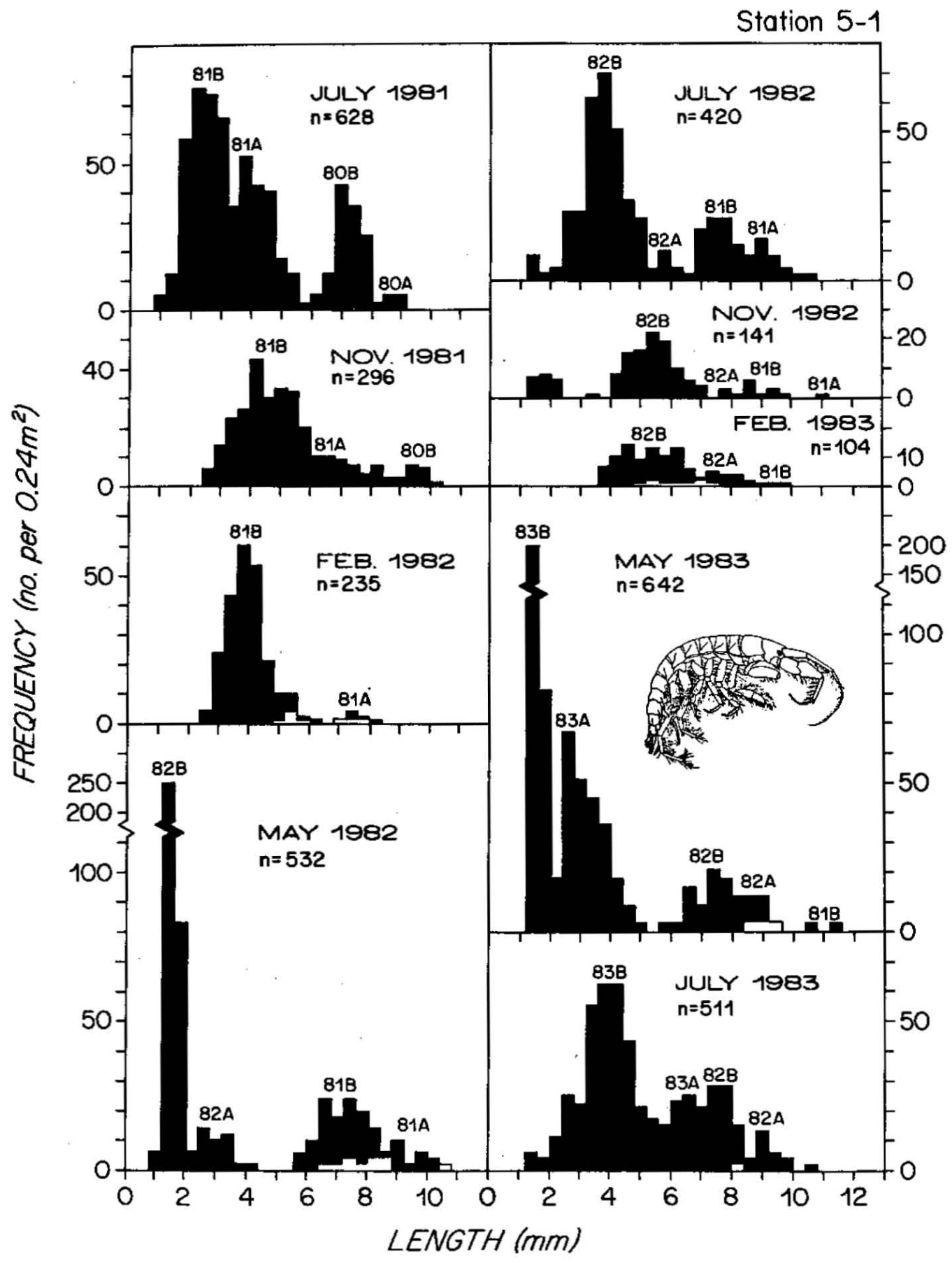

Figure 1-4. Length-frequency of Unciola inermis at Station 5-1. White blocks in the histograms represent ovigerous females. From Collie (1985). 
Station 5-1

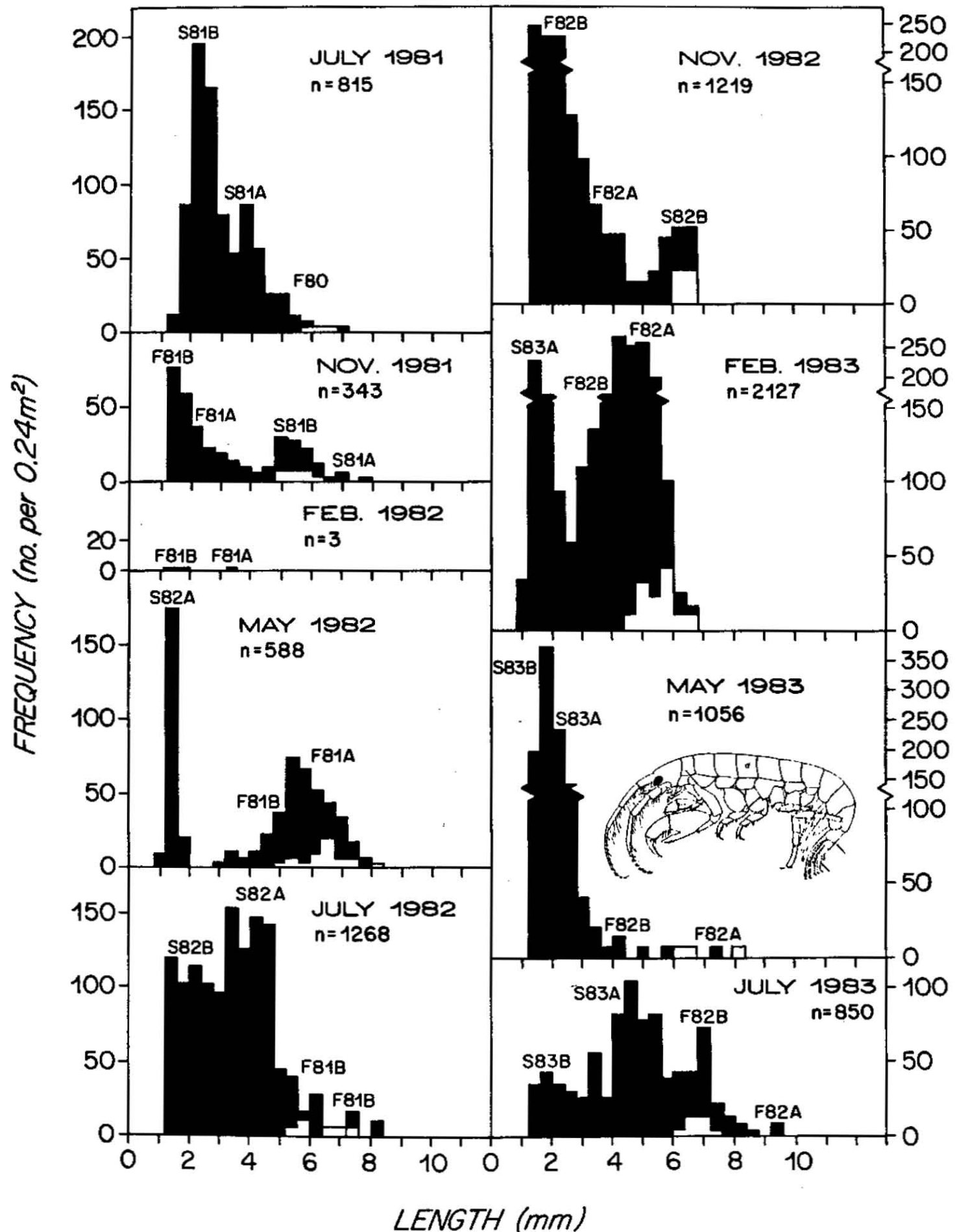

Figure 1-5. Length-frequency of Ericthonius fasciatus at Station 5-1. White blocks in the histograms represent ovigerous females. From Collie (1985). 
Unciola Inermis at Station 5 (F1g. 1-4) is an annual species with ovigerous females present in February and May (a few In July 1983) and recruitment of juveniles in May. A length of $11 \mathrm{~mm}$ may be reached after the maximum iffe-span of about 1.5 years. The minimum and maximum lengths of ovigerous females were 5.0 and $10.5 \mathrm{~mm}$. A few Individuals may survive for a second year (e.g. cohort 81B).

At the same station, ovigerous females of Ericthonius fasciatus (Fig. 1-5) were present throughout the year but recruitment of juveniles was concentrated during the spring and fall, resulting in 'two generations per year. A striking feature of the distribution of E. fasciatus at this station was 1ts virtual disappearance In February 1982 and subsequent recolonization in May. The reasons for this disappearance and the source of colonists will be discussed below. Animals of the spring generation may reach a maximum length of $7 \mathrm{~mm}$ in 6 months; those of the fall generation may reach a maximum of $9 \mathrm{~mm}$ in 8 months. Minimum and maximum lengths of ovigerous females were 4.8 and $8.4 \mathrm{~mm}$, respectively.

In all three specles, each generation appears to be composed of two modes (these cohorts are labeled A and B in Figs. 1-3, 1-4 and 1-5). Bimodality is more distinct for Unclola Inermis and Ampelisca agassizi because their reproduction is more highly synchronous than that of Ericthonius fasciatus. A and B cohorts are apparent for E. fasclatus in July but are less obvious at other times of the year.

To test whether these $A$ and $B$ cohorts are true modes, I ran NORMSEP assuming elther one or two modes per generation. In almost all cases, the chi-square was lower with two modes per generation. A and B cohorts were more difficult to separate for adults because, with time, varlablity in individual growth rates obscures the modes. Figure 1-6 is an example of the result obtained using NORMSEP to fit the length-frequency 


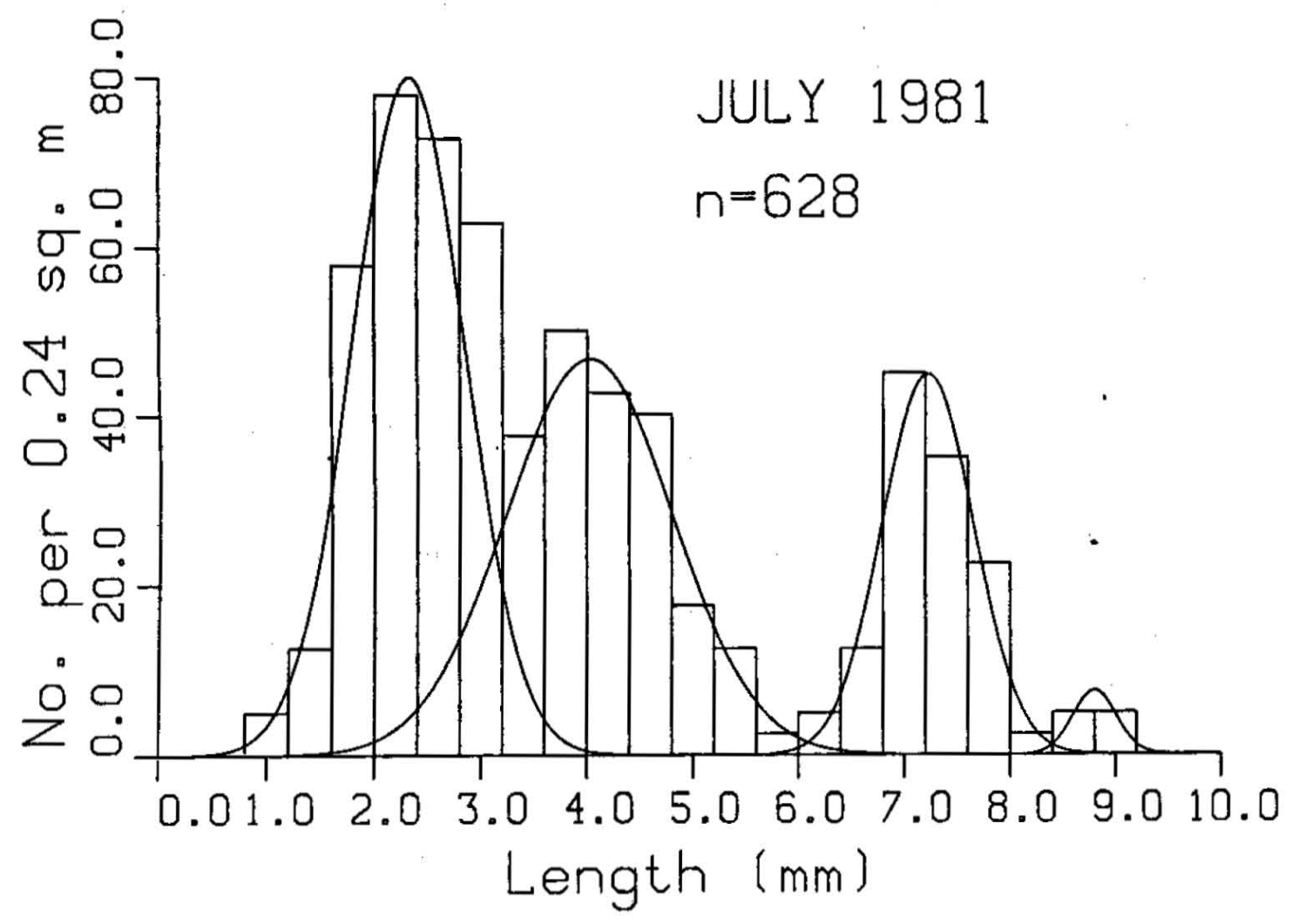

Figure 1-6. Example of the result obtained using computer program NORMSEP to fit normal curves to the observed lengthfrequency distribution of Unciola inermis at Station

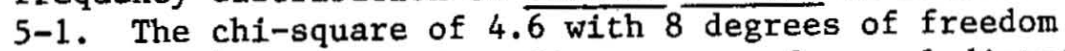
indicates that these data fit a group of normal distributions better than 80 percent of samples would be expected to by chance alone. From Collie (1985). 


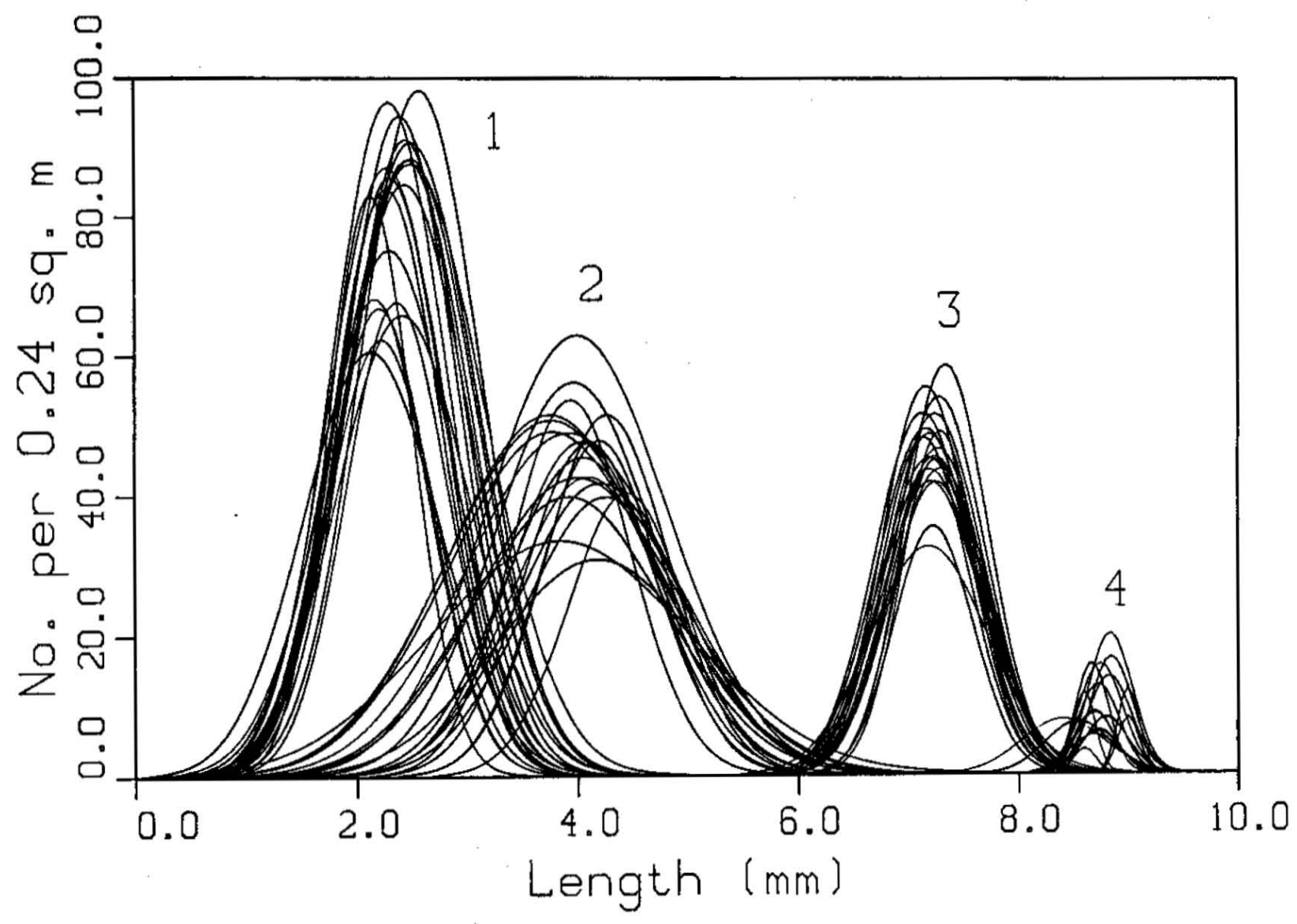

Figure 1-7. Twenty sets of normal curves generated by bootstrap simulation of the Unciola inermis observed length-frequency data plotted in Fig. 1-6. 
Table 1-1. Bootstrap parameter estimates corresponding to the normal curves plotted in FIg. 1-7. L $L_{1}$ are the mean lengths and $N_{1}$ the mean numbers of each of the four sets of normal curves shown In Fig. 1-7. The variances of these parameters constitute the diagonal of the varlance-covarlance matrix.

\begin{tabular}{lcccccccc}
\hline & & & \multicolumn{7}{c}{ VARIABLE } \\
& $\mathrm{L}_{1}$ & $\mathrm{~N}_{1}$ & $\mathrm{~L}_{2}$ & $\mathrm{~N}_{2}$ & $\mathrm{~L}_{3}$ & $\mathrm{~N}_{3}$ & $\mathrm{~L}_{4}$ & $\mathrm{~N}_{4}$ \\
\hline Observed: & 2.32 & 104.9 & 4.02 & 91.7 & 7.23 & 48.5 & 8.80 & 3.9 \\
Bootstrap: & 2.34 & 105.61 & 4.02 & 90.06 & 7.24 & 48.59 & 8.72 & 4.75
\end{tabular}

VARIANCE-COVARIANCE MATRIX

$\begin{array}{lrrrrrrrrr}\mathrm{L}_{1} & 0.018 & & & & & & \\ \mathrm{~N}_{1} & 2.100 & 417.639 & & & & & \\ \mathrm{~L}_{2} & 0.015 & 2.712 & 0.027 & & & & \\ \mathrm{~N}_{2} & -1.931-400.452 & -2.626 & 421.999 & & & & \\ \mathrm{~L}_{3} & -0.002 & -0.264 & -0.003 & 0.274 & 0.003 & & \\ \mathrm{~N}_{3} & -0.260 & -21.968 & -0.053 & -14.599 & -0.042 & 40.219 & \\ \mathrm{~L}_{4} & -0.004 & -0.677 & -0.008 & 0.852 & 0.001 & -0.170 & 0.022 & \\ \mathrm{~N}_{4} & 0.091 & 4.613 & -0.034 & -6.781 & 0.030 & -3.658 & -0.002 & 5.873\end{array}$


distribution of Unctola Inermis in July 1981.

The bootstrap analysis was performed on the observed length-frequency distribution plotted in Fig. 1-6. I simulated 20 sets of lengthfrequency data and fit NORMSEP in the same manner as the observed data. The 20 sets of normal curves are superimposed in Fig. 1-7; means, variances and covariances of the bootstrap parameter estimates are listed in Table 1-1. Inspection of F1g. 1-7 together with Table 1-1 yields the following insights into this method of size-frequency analysis.

The mean length $\left(L_{1}\right)$ estimates are relatively insensitive to sample variability. This is indicated by the low varlances of the $\mathrm{L}_{1}$ parameters in Table 1-1. In contrast, estimated numbers $\left(N_{1}\right)$ in each mode are very sensitive to sample variability. This is illustrated by the large spread in heights of the normal curves and by the high varlances of the $\mathrm{N}_{1}$ parameters.

There is a large amount of scatter where modes overlap, for example between modes 1 and 2 . This overlap results in the very high negative covariance between $N_{1}$ and $N_{2}$, the numbers in modes 1 and 2 . The overlap also causes positive covarlance between $\mathrm{L}_{1}$ and $\mathrm{N}_{1}, \mathrm{~L}_{2}$ and $\mathrm{N}_{1}$, and negative covariance between $\mathrm{L}_{1}$ and $\mathrm{N}_{2}, \mathrm{~L}_{2}$ and $\mathrm{N}_{2}$. In contrast there is little scatter where modes are distinct, for example between modes 2 and 3 . Because these modes are distinct, the covariances among $L_{2}, N_{2}, L_{3}$ and $N_{3}$ are relatively low.

Growth curves for each cohort are shown in Fig. 1-8. The vertical bars equal \pm 1 standard deviation as estimated by NORMSEP. Where vertical bars overlap, the modes are indistinct. A common feature of all three species is that the growth rate decreases in the winter; the mean length of Unctola Inermis, cohort $81 \mathrm{~B}$ and $82 \mathrm{~B}$, actually decreased between February and May. Ericthonlus fasclatus had the fastest growth rate 


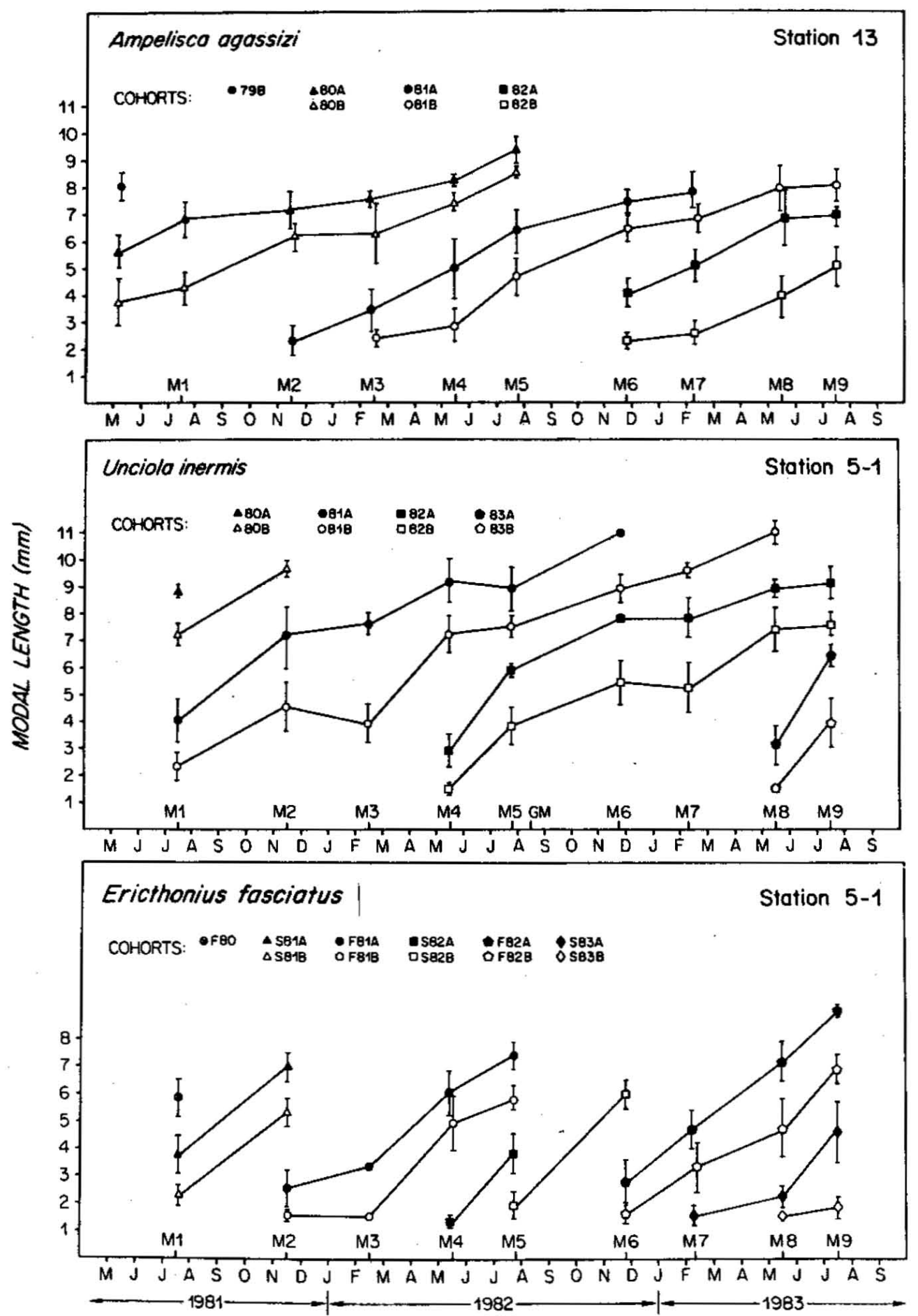

Figure 1-8. Growth in mean length of each cohort. Vertical bars equal \pm 1 standard deviation as estimated by NORMSEP. From Collie (1985). 

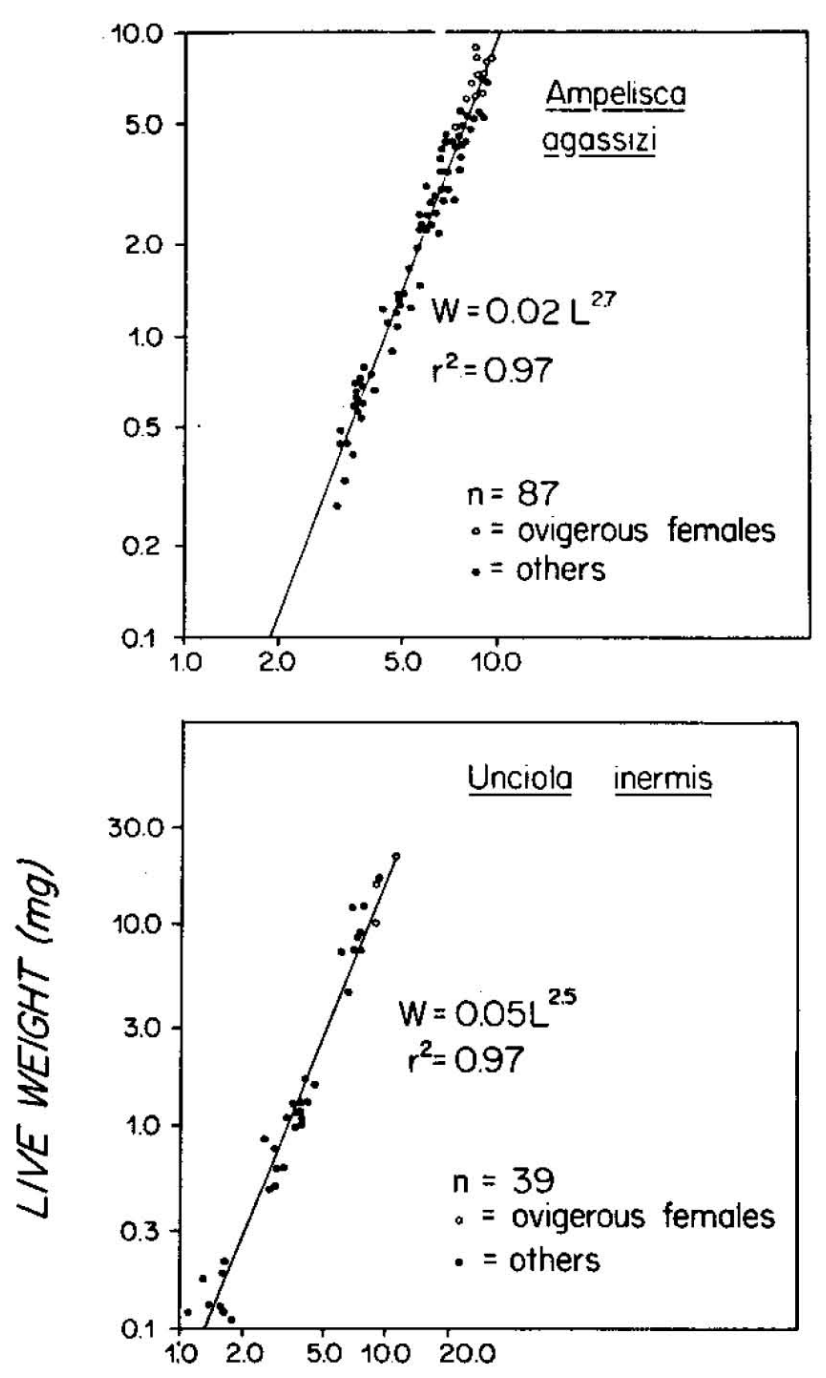

Figure 1-9. Length-weight relationships as fitted by linear least squares. From Collie (1985).

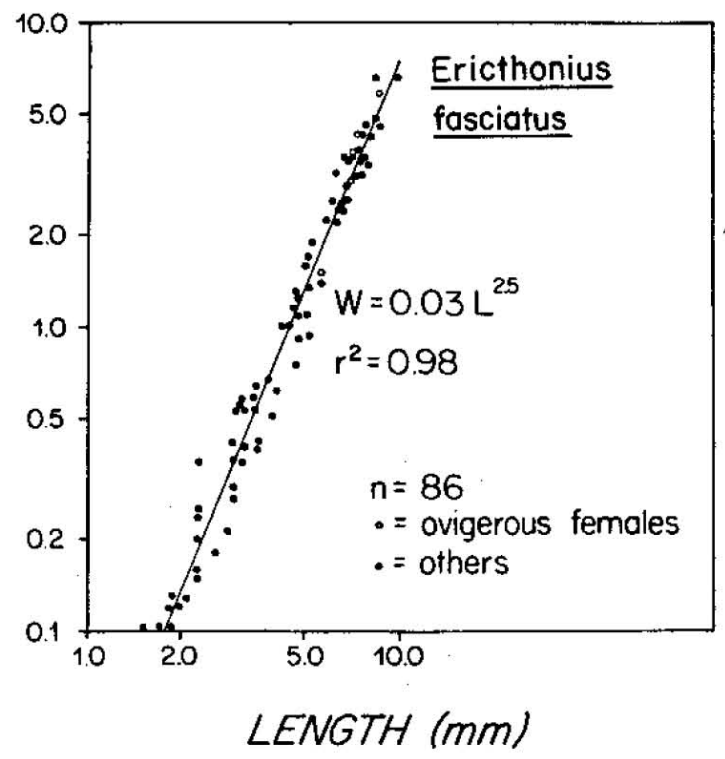


Table 1-2. Ash-free dry weight determination.

\begin{tabular}{|c|c|c|c|}
\hline Spec1es: & A. agassiz1 & U. Inermis & E. fasclatus \\
\hline n (groups): & 3 & 3 & 4 \\
\hline \% water: & 75.9 & 74.4 & 80.9 \\
\hline$\%$ ash: & 7.1 & 8.5 & 6.1 \\
\hline$\%$ ash-free dry weight: & 17.0 & 17.1 & 13.0 \\
\hline
\end{tabular}

Table 1-3. Blomass and production estimates ( $\mathrm{gdw}=\mathrm{grams}$ dry welght).

\begin{tabular}{|c|c|c|c|c|c|}
\hline Specles: & A. agassizi & U. In & ermis & $\underline{E} \cdot \underline{f a}$ & clatus \\
\hline Station: & 13 & $5-1$ & $5-28$ & $5-1$ & $5-28$ \\
\hline 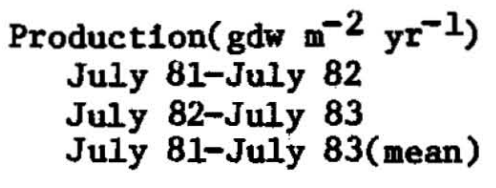 & $\begin{array}{l}1.26 \\
2.79 \\
2.02\end{array}$ & $\begin{array}{l}3.21 \\
2.53 \\
2.87\end{array}$ & 2.04 & $\begin{array}{l}1.44 \\
3.12 \\
2.28\end{array}$ & 1.88 \\
\hline 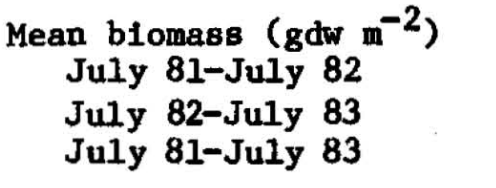 & $\begin{array}{l}0.94 \\
1.99 \\
1.48\end{array}$ & $\begin{array}{l}1.20 \\
1.19 \\
1.15\end{array}$ & 1.55 & $\begin{array}{l}0.37 \\
0.79 \\
0.56\end{array}$ & 0.67 \\
\hline 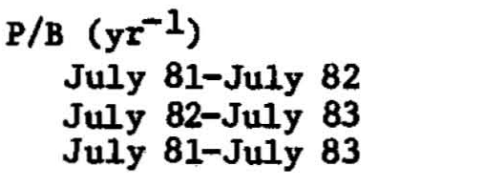 & $\begin{array}{l}1.34 \\
1.40 \\
1.36\end{array}$ & $\begin{array}{l}2.68 \\
2.13 \\
2.50\end{array}$ & 1.32 & $\begin{array}{l}3.89 \\
3.95 \\
4.07\end{array}$ & 2.80 \\
\hline
\end{tabular}


(max. $1 \mathrm{~mm} / \mathrm{mo})$ with $\mathrm{U}$. inermis intermediate and Ampelisca agassizi the slowest. Thus, there is an inverse relationship between growth rate and 11fe-span.

Length-weight relationships are plotted in Fig. 1-9. Despite the Inherent variability of wet weights, a significant regression was obtalned for each species by using a relatively large sample size. The regression coefficient (b) of all three specles is significantly less than 3. This indicates that growth in weight is not isometric; weight increases less rapidly than does length. Table 1-2 summar1zes the ash-free dry weight determinations. Compared to the other two species, Ericthonius fasclatus not only has a lower weight for a given length, it also has a higher percentage of water. Thls could explain how 1 t grows faster than do the other two species -- by produclng less dry weight per unit length.

Production and biomass calculations are given in full in Appendix A and the estimates summarized in Table 1-3. These estimates differ slightly from those presented in Collie (1985) and Collie and Curran (1985) because Eq. 1.1 was used to est1mate mean weight in the earlier papers, instead of Eq. 1.2 which is more strictly correct. Ericthonius fasciatus had the highest $P / B$ followed by Unciola Inermis then Ampelisca agassizi. Comparing the two years, the $\mathrm{P} / \mathrm{Bs}$ varled much less than did production and biomass separately. The maxlmum change in P/B was a $20 \%$ decrease by U. Inermis; however production and biomass each changed by as much as 2.2 times. Interannual differences in $\mathrm{P} / \mathrm{B}$ also were less than the differences between species. The Station 5-28 data show that there were between-station differences in production, mean biomass and $P / B$. Compared to the same species at Station 5-1, amphipods at Station 5-28 grew more slowly and lived longer (growth curves not shown); these 
Table 1-4. Sex ratios of Ampelisca agassiz1 at Station 13.

\begin{tabular}{|c|c|c|c|c|c|}
\hline & Grab & samples & Fish & stomachs & guts ys. \\
\hline Date & $\mathbf{F}$ & $M \quad 1: 1^{1}$ & $F$ & M $\quad 1: 1^{1}$ & $\mathrm{grabs}^{2}$ \\
\hline
\end{tabular}

July 1982

insufficient numbers

November 1982

$\begin{array}{lrrrrrrr}\text { numbers } & 24 & 18 & \text { N.S. } & 21 & 7 & * * & \text { N.S. } \\ \text { proportions } & 0.57 & 0.43 & & 0.75 & 0.25 & & \end{array}$

February 1983

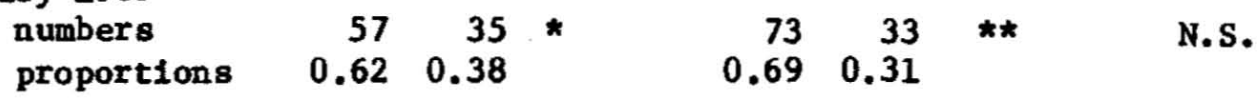

May 1983

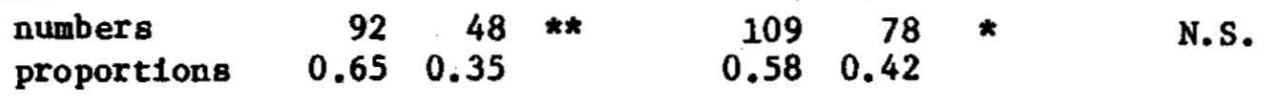

1. G-test of observed sex ratios against 1:1 ratio.

2. G-test of grab-sample against fish-stomach sex ratios. 
Table 1-5. Sex ratios of Unclola 1nermis at Station 5-1.

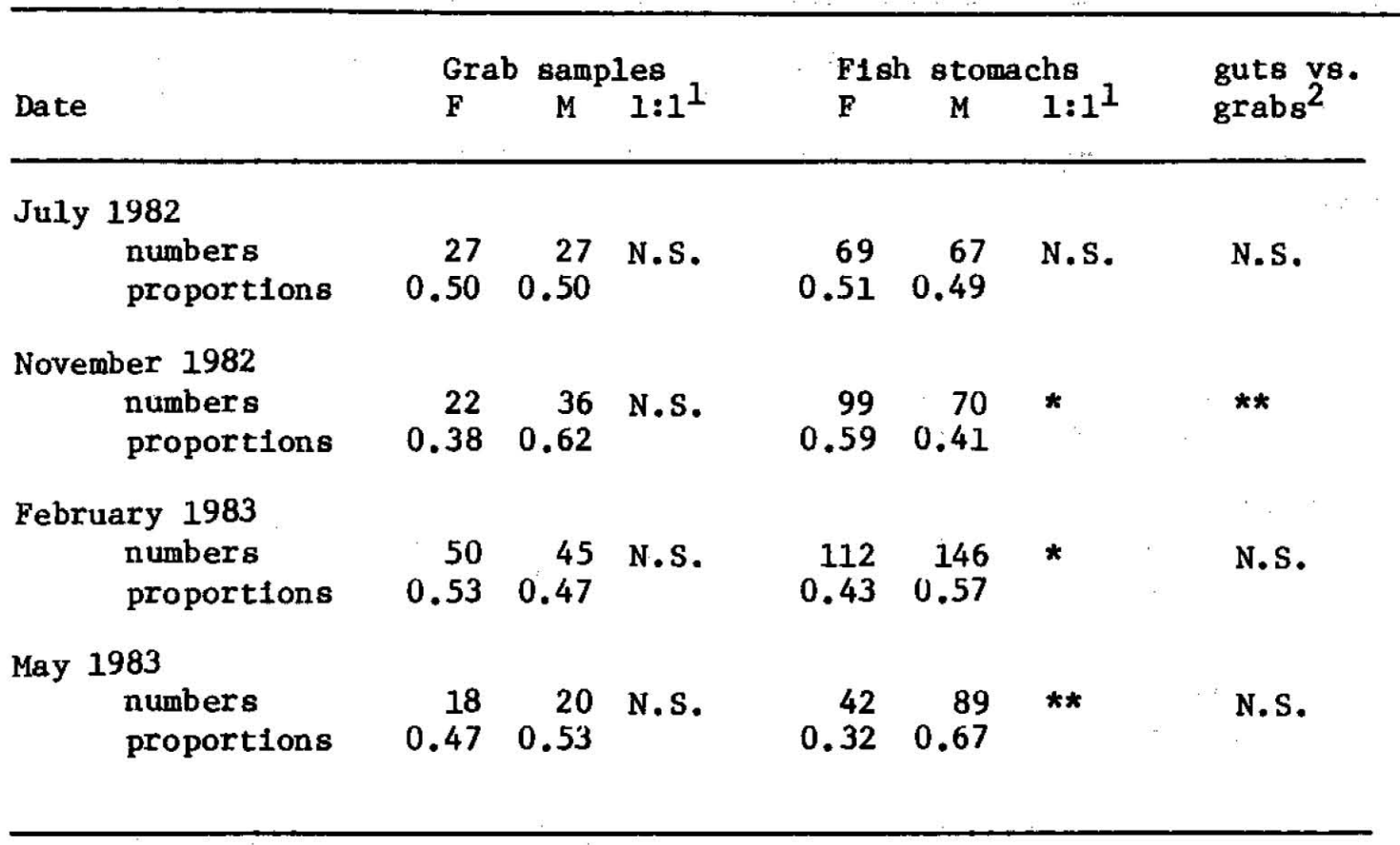

1. G-test of observed sex ratios against $1: 1$ ratio.

2. G-test of grab-sample against fish-stomach sex ratios. 
Table 1-6. Sex ratios of Ericthonlus fasclatus at Station 5-1.

\begin{tabular}{|c|c|c|c|c|c|c|c|}
\hline \multirow[b]{2}{*}{ Date } & \multirow{2}{*}{$\begin{array}{l}\text { Grab } \\
F\end{array}$} & \multicolumn{2}{|c|}{ b samples. } & \multicolumn{3}{|c|}{ F1sh stomachs } & \multirow{2}{*}{$\begin{array}{l}\text { guts yo. } \\
\text { grabs }^{2}\end{array}$} \\
\hline & & $\mathbf{M}$ & $1: 1^{1}$ & $\mathbf{F}$ & M & $1: 1^{1}$ & \\
\hline $\begin{array}{l}\text { July } 1982 \\
\text { numbers } \\
\text { proportions }\end{array}$ & $\begin{array}{r}48 \\
0.68\end{array}$ & $\begin{array}{r}23 \\
0.32\end{array}$ & $\star \star$ & $\begin{array}{r}166 \\
0.67\end{array}$ & $\begin{array}{r}80 \\
0.33\end{array}$ & $\star *$ & N.S. \\
\hline $\begin{array}{l}\text { November } 1982 \\
\text { numbers } \\
\text { proport1ons }\end{array}$ & $\begin{array}{r}24 \\
0.57\end{array}$ & $\begin{array}{r}18 \\
0.43\end{array}$ & N.S. & $\begin{array}{r}112 \\
0.46\end{array}$ & $\begin{array}{r}131 \\
0.54\end{array}$ & N.S. & N.S. \\
\hline $\begin{array}{l}\text { February } 1983 \\
\text { numbers } \\
\text { proportions }\end{array}$ & $\begin{array}{r}79 \\
0.54\end{array}$ & $\begin{array}{r}66 \\
0.46\end{array}$ & N.S. & $\begin{array}{r}85 \\
0.44\end{array}$ & $\begin{array}{r}109 \\
0.56\end{array}$ & N.S. & N.S. \\
\hline $\begin{array}{l}\text { May } 1983 \\
\text { numbers } \\
\text { proportions }\end{array}$ & $\begin{array}{r}5 \\
0.45\end{array}$ & $\begin{array}{r}6 \\
0.55\end{array}$ & N.S & $\begin{array}{r}95 \\
0.45\end{array}$ & $\begin{array}{r}115 \\
0.55\end{array}$ & N.S. & N.S. \\
\hline
\end{tabular}

1. G-test of observed sex ratios against $1: 1$ ratio.

2. G-test of grab-sample against fish-stomach sex ratios. 


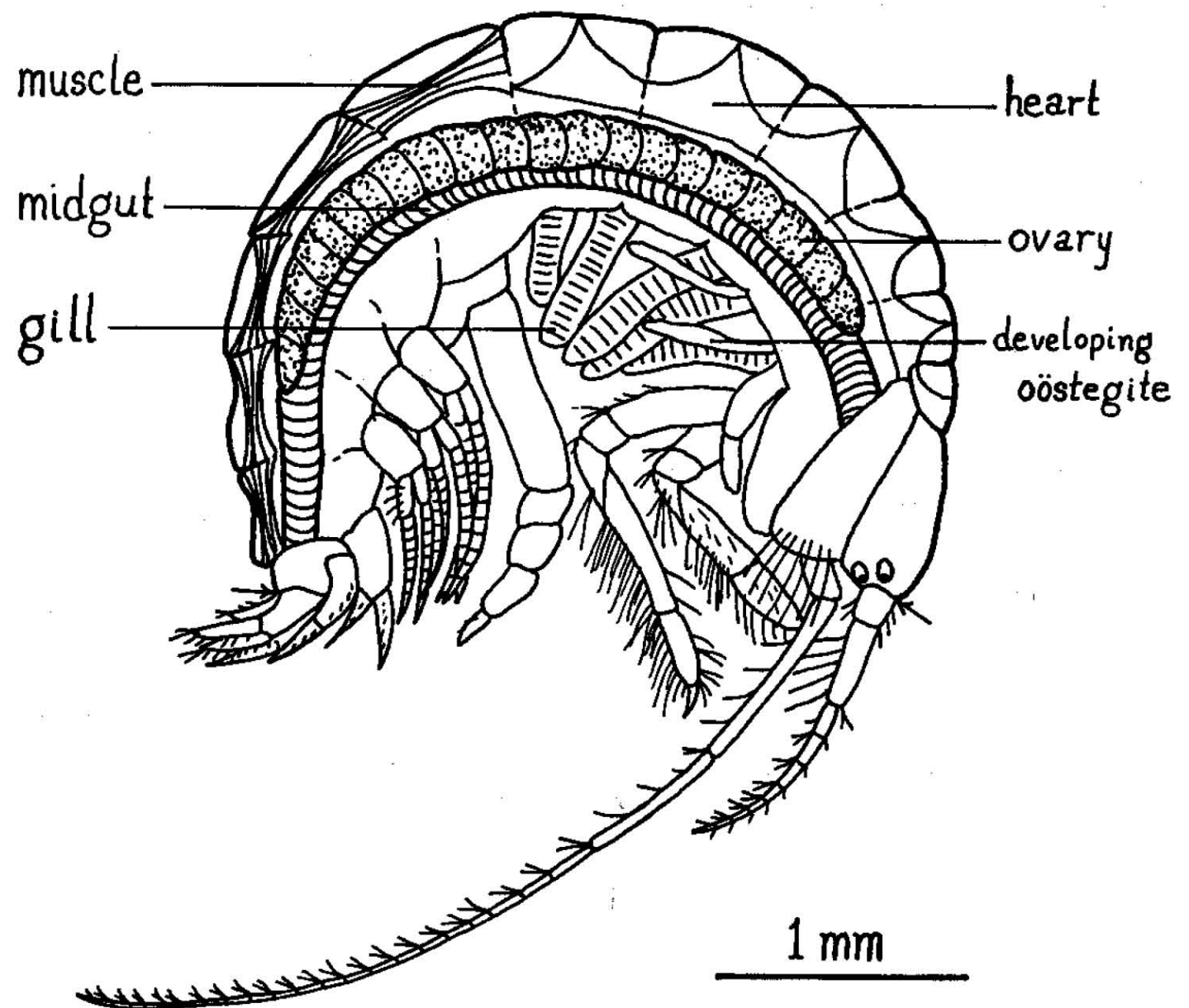

Figure 1-10. Dissection of Ampelisca agassizi. This amphipod, a developing female, was collected at Station 13 in February 1983. 
differences account for the lower P/Bs at Station 5-28.

I determined sex ratios of the three amph1pod species for the period July 1982 to May 1983 (Tables 1-4 to 1-6). In each case the sex ratio in the grab sample is compared to the corresponding sex ratio of amphipods found in yellowtail flounder stomachs at the same site (see Chapter 2). These sex rat1os apply only to the adult (larger than $5 \mathrm{~mm}$ ) amphipods. The sex ratio of Ampelisca agassiz1 (Table 1-4) was skewed toward females for both those from grab samples and those from flsh stomachs. In no case was the fish-stomach sex ratio significantly different from that of the grab samples.

The sex ratio of Unciola 1nermis (Table 1-5) from the grab samples was not significantly different from a 1:1 ratio; on 3 out of 4 sampling occasions, the sex ratio from the fish stomachs was different from a $1: 1$ rat1o. In February and May, the fish-stomach rat1o was skewed toward males but was not statistically different from the grab-sample ratio. In November the fish-stomach sex ratio was skewed toward females and was significantly different from the grab-sample ratio. In July, the sex ratio of Erlcthonius fasclatus (Table 1-6) was skewed toward females both In the grab samples and in the fish stomachs. In no case was the sex ratio in the grab samples significantly different from that in the fish stomachs.

In these amphipod specles, the paired ovaries are tubular, with a single row of eggs in each ovary (F1g. 1-10). Sheader (1977) found, in Ampelisca tenuicornis, the length of the mature ovary to be proportional to female body length. If egg size is constant, egg number should be proportional to female body length. In the three specles studied here, egg number appears to increase with female length (F1g8. 1-11 to 1-13), but this trend 18 obscured by the scatter in egg numbers. This scatter 


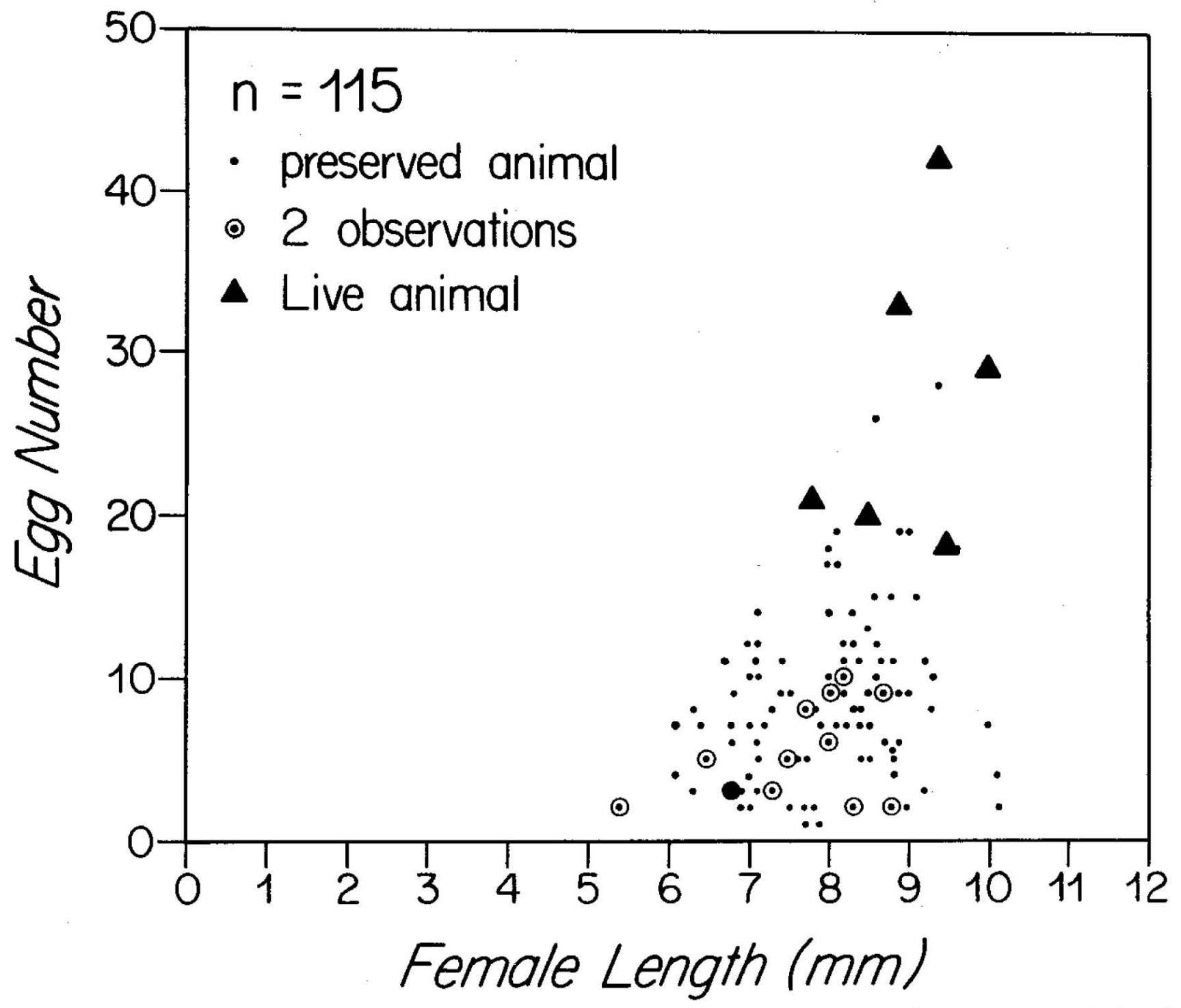

Figure 1-11. Lgg number plotted against length of ovigerous Ampelisca agassizi females. 


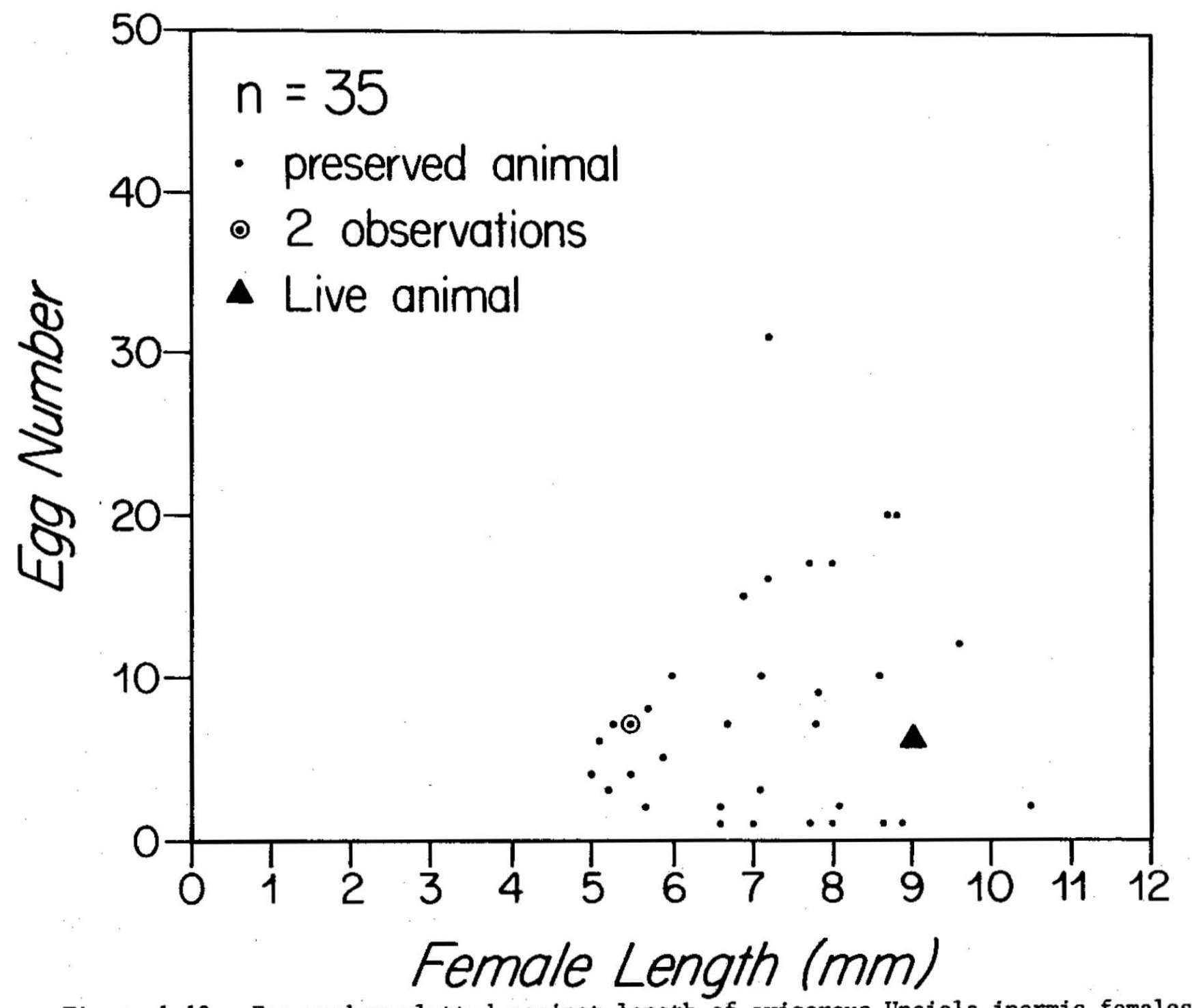

Figure 1-12. Egg number plotted against length of ovigerous Unciola inermis females. 


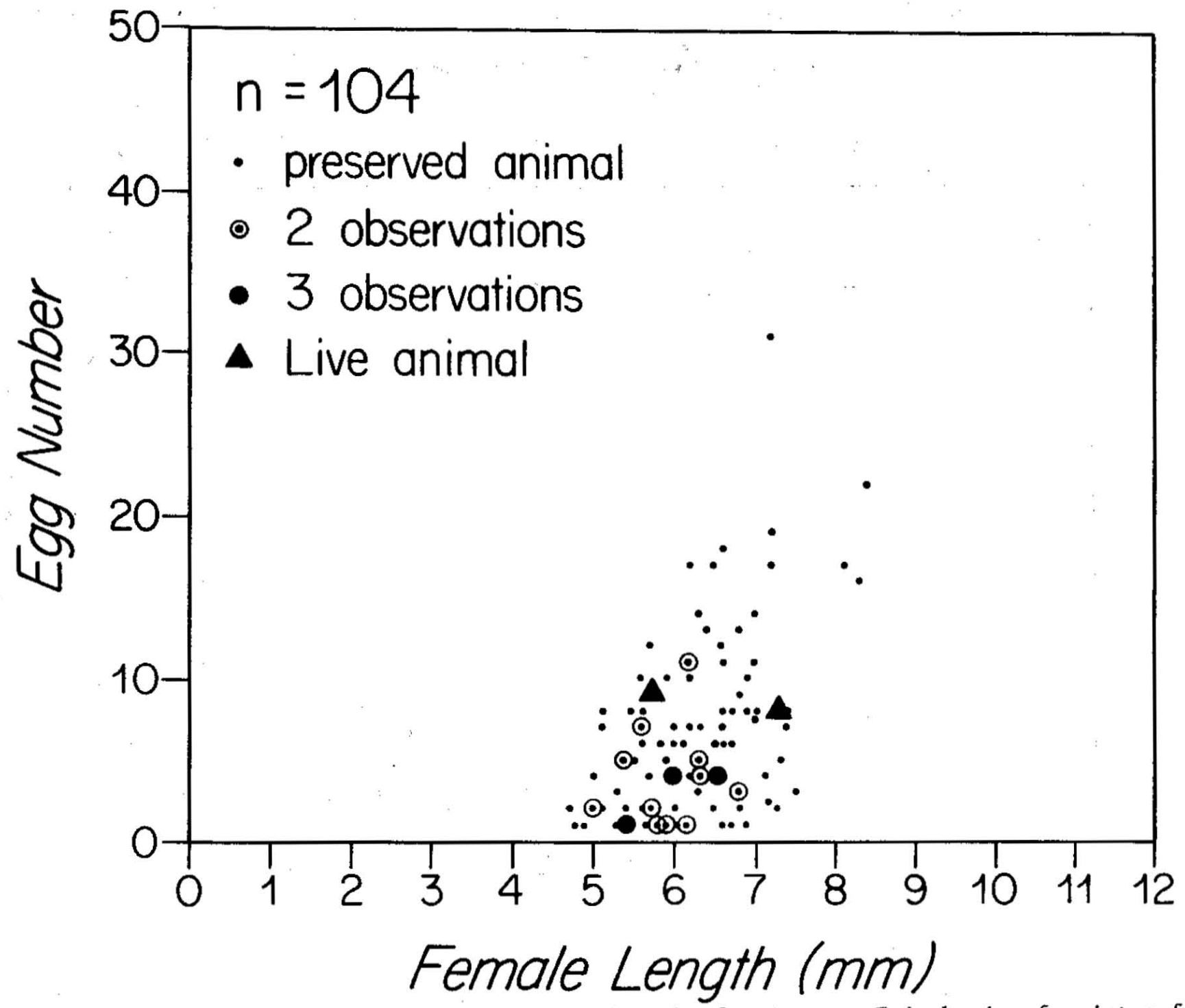

Figure 1-13. Egg number plotted against length of ovigerous Ericthonius fasciatus females. 
1s probably largely due to egg loss during sample processing. Live Aagassiz1 (F1g. 1-11) had more eggs than preserved females of equal lengths, probably because the live animals were handled more gently and were less subject to egg 1oss. Therefore, the maximum egg number in each size class may represent the true fecundity better than mean egg number. More accurate egg counts could be obtained by careful sample treatment or by counting egg number in the ovaries.

I observed parasites in the broods of all three amphipod species. In size and shape the parasite mimics the developing amphipod embryos. The parasite body is pear shaped; a head equiped with two antennae protrudes from a "collar" in the anterlor end. The varlous life stages found in $\underline{A}$. agassizi broods (Fig. 1-14) suggest that the life cycle of the parasite is synchronized with that of 1 ts host. Some of the parasite bodies appeared distended; I assumed these were in a reproductive state. A large number of parasite eggs are packaged in a transparent ovisac that is the same size as one amphipod egg. The juvenile parasites presumably hatch at the same time as the juvenile amphipods and would thus be able to find a new host without leaving the protection of the brood pouch. The incidence of these parasites was low and presence of a parasite did not appear to interfere with development of the amphipod embryos.

The parasite 18 difficult to identify because of 1 ts globular body form. It 18 probably a copepod of the family Choniostomatidae (Dr. A. Humes, personal communication). Choniostomat1d copepods all parasitise other Crustacea (Bradford 1975) and have been found on at least eight species of ampeliscid amphipods (e.g. Sheader 1977, Dauvin 1984). Adults are thought to be relatively immobile because of the small size of their limbs which are adapted for clinging. All stages have a distinctive sucking mouth cone through which piercing mandibles are extruded, 

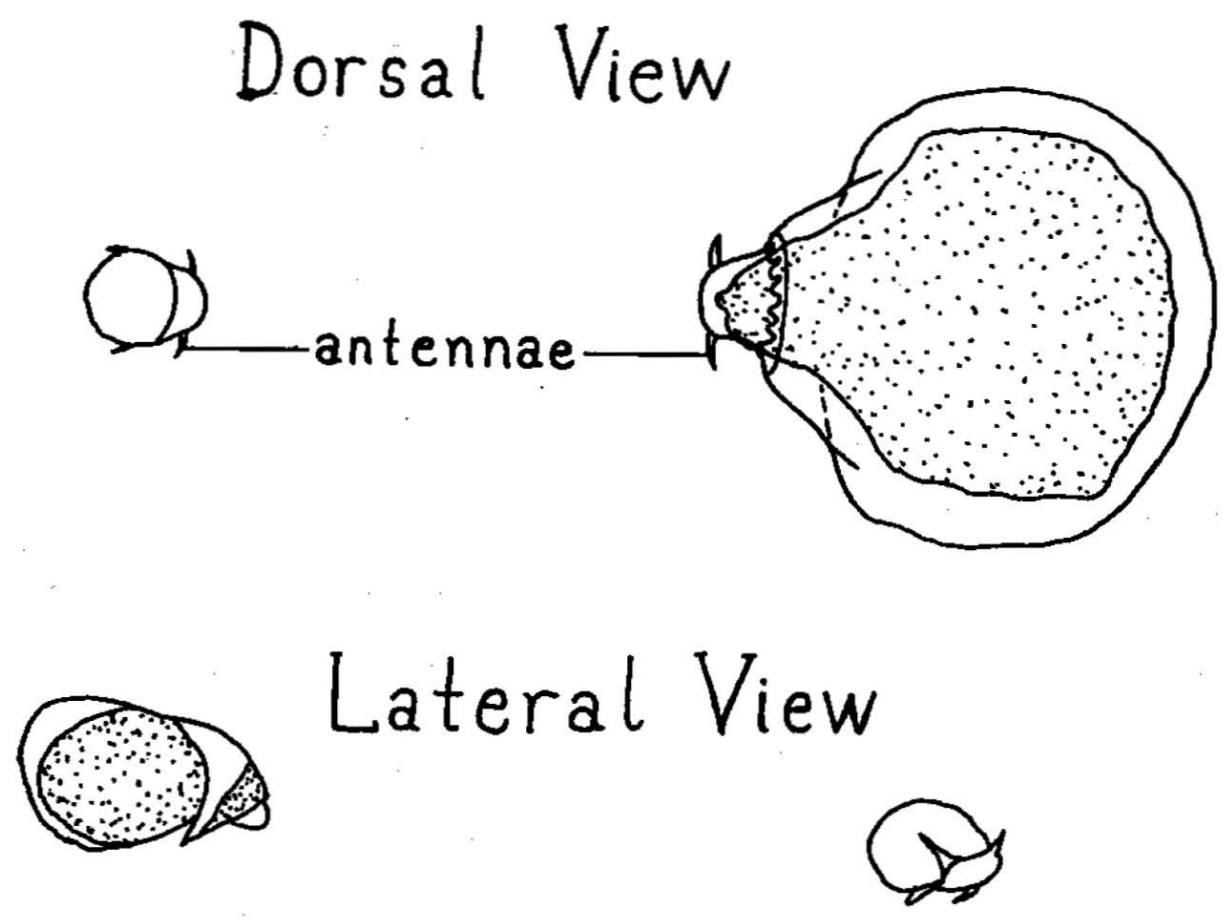

\section{amphipod}

embryo

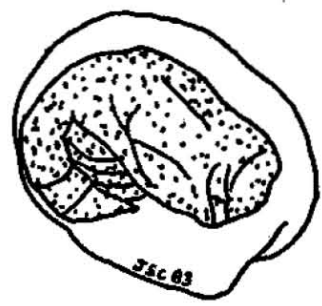

ovisac

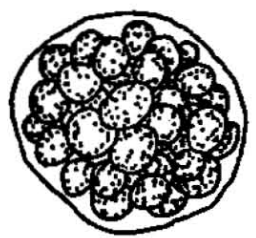

Figure 1-14. Brood parasites on Ampelisca agassizi collected at Station 13 in November 1982. The various parasite stages are shown in relation to a developing amphipod embryo. The parasite is a copepod, probably of the family Choniostomatidae. 
presumably enabling them to feed on the blood of their host. The young generally hatch as stage I copepodites and then find a new host.

Table 1-7 compares a number of life-history tralts of the three species. The coefficient of variation of sample means is a measure of the patchiness of the species distribution relative to the size of the grab and the area over which the replicates were taken. Thus Ericthonius fasciatus is the most patchily distributed and Ampelisca agassizi the least so. Fish predation data are based on analysis of yellowtail flounder stomachs collected at the same stations (see Chapter 2). Although results given here measure the mean number of prey per predator, not the predation rate, these data suggest that flounder eat $\underline{E}$. fasciatus most often and $\underline{A}$. agassiz1 least often. 
Table 1-7. Summary of life-history traits (CV = coefficient of variation).

\begin{tabular}{lccc} 
Species: & A. $\frac{\text { agassizi }}{\text { blennial }}$ & U. $\frac{\text { Inermis }}{\text { annual }}$ & E. fasclatus \\
Generation time: & $1.3-1.4$ & $1.3-2.7$ & semi-annual \\
P/B $\left(\mathrm{yr}^{-1}\right.$ ): & 40.5 & 54.8 & $83-4.1$ \\
CV of sample means: & 15.0 & 72.4 & 88.4 \\
Mean no. per fish stom: & fine sand & medium sand & shell fragments \\
Sediment affinity: & & & \\
\hline
\end{tabular}


The method of length-frequency analysis employed in this study depends critically on the abllity to distinguish cohorts and to follow them through time. The three amphipod spectes considered here lend themselves to this type of analysis because they are relatively short-lived and generations are separable.

Bimodal recrultment has been observed in other amphipod species by other authors. Mills (1967b) found bimodality in both winter and summer generations of Ampelisca abdita. Since the time difference between modes as estimated from the growth curve was about 28 days, Mills suggested that breeding may somehow be linked to the lunar cycle. Corophium volutator, studied by Moller and Rosenberg (1982), has a 1ife history

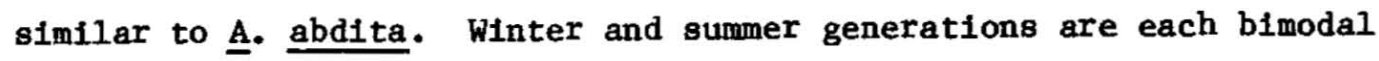
and, judging by the authors' Fig. 4, within-generation cohorts are released approximately one month apart. Ampelisca tenuicornis, collected off the northeast coast of England (Sheader 1977), also exh1bits bimodal generations. Sheader suggested that this recruitment pattern results from the simultaneous onset of breeding and the synchronous production of a second brood by a proportion of the females. The following spring the first brood matures earlier than the second, thus relnforcing the double peak of recruitment. Dauvin (1984) found multimodal recruitment (up to 11 cohorts per generation) in A. typica, A. sarsi and ‥ tenuicornis. For the three amphipod species I studied, the cue for the onset of breeding is not apparent because ovigerous females of at least one species were present during all seasons of the year. Onset of breeding is a function of length in that the cohorts mature sequentlally with the largest females maturing first. This tends to reinforce the bimodal 
recruitment but probably is not enough, in itself, to maintain the pattern.

Sheader (1977), Dauvin (1984) and Kemp et al. (in press) found females carrying embryos in their marsupla and, simultaneously, wel1-developed oocytes in the ovaries; it is likely that some of these females bred a second time. The development time for ampeliscid embryos ranges from 1 month in $\underline{A}$. tenulcornis (Sheader 1977) and $\underline{A}$. sarsi (Dauvin 1984) to 5 months in A. macrocephala (Kanneworff 1965). In my study, some cohorts had ovigerous females on two consecutive sampling dates, suggesting that multiple broods are possible. The development time for embryos of these species is not known. In developing females the ovaries were clearly visible (F1g. 1-10) but none of the ovigerous females observed also had developing oocytes.

In ampeliscid amphipods, males mature at a definitive last moult that almost amounts to a metamorphosis. The modifications during this terminal moult, which include slimming of the body and increase in pleon muscle size, are associated with improved swimming ability and adaptation for a short, free-swimming, adult life (Mills 1967b).

In several studies of ampeliscid life history, the density of adult males declined, following the breeding season in early summer, to almost zero by the end of the summer. Th1s pattern was observed in A. macrocephala (Kanneworff 1965), A. tenuicornis (Sheader 1977) and A. brevicornis (Klein et al. 1975, Hastings 1981a). The males are presumed to leave the bottom as they mature. In night-t1me plankton hauls Hastings (1981a) found only mature, metamorphosed male $\underline{A}$. brevicornis and these pelag1c males had spermatophores extruding from the penes. In contrast, M111s (1967b) found all stages of A. abdita, from juveniles to fully adult males and females, in night-time plankton tows in Barnstable 
Harbor. Interestingly, the sex ratio of A. abdita was roughly $1: 1$. The sex ratios of A. agassizi are complicated by the presence of intersexes: animals with penile papillae and rudimentary oostegites. Such intersexes, also observed in A. brev1cornis (Hastings 1981a), A. spinipes (Mills 1963) and A. macrocephala (Kanneworf 1965), have been called gynomorphic males. Hastings (1981b) made a histological study of five intersex A. brevicornis. All five were confirmed as males by the presence of 1mmature testicular tissue and all five were Infested with internal parasites. This phenomenon, which appears to be a form of parasitic castration, is widespread throughout the crustacea. In A. agassiz1 $4 \%$ of all 1dentifled males were gynomorphic.

Mature male $\underline{A}$. agassiz1 were present in May; the percent of males that were mature was slightly higher in the fish stomach contents (15\%) than in the grab samples (12\%). As the adults matured, from November to May, the proportion of males decreased in the grab samples and increased in the fish stomachs. This observation is consistent with the hypothesis that males leave the bottom as they mature and are then more vulnerable to fish predation. This trend, however, was slight and did not significantly alter the sex ratios, which remained skewed toward females at all seasons.

The proportion of male Unctola inermis in the diet 1ncreased from November to May as the adults matured, suggesting that mature males enter the water column and are more prone to predation. Again, this trend was slight and didn't appear to drive the sex ratio in the benthos away from a $1: 1$ ratio.

Because Ericthonius fasclatus is capable of year-round reproduction, there is no prediction of how the sex ratio should change. The sex ratio in the fish stomach contents mirrored that in the grab samples. Of the 
three species, E. fasclatus is the most eplbenthic in habit. Together, these observations suggest that both sexes are equally vulnerable to fish predation. In summary there is some evidence that mature males of $\underline{A}$. $\underline{\text { agassizI }}$ and $\underline{U}$. Inermis leave the sea bottom but this pelagic habit does not make them significantly more vulnerable than females to predation by yellowtail flounder.

Comparison of the 1ife-history strategles of the three amphipod species (Table 1-7) yields a consistent pattern. Ampellsca agassizi is mainly a deposit feeder on fine sediments in weak curents; its tube extends vertically in the substratum, providing a refuge from fish predation. Of the three species, A. agassizi has the slowest growth, lowest mortality and is eaten least by flounder. The low turnover rate and less patchy distribution could be related to this species' affinity for finer sediments at greater water depths where the sediments presumably are disturbed less frequently.

In contrast, Ericthonius fasciatus is an epifaunal tube builder, living in stronger currents, perhaps mainly as a filter feeder. Among the three specles, E. fasclatus has the fastest growth, highest mortallty and 18 eaten most by flounder. The high turnover rate and patchier distribution of this species may be related to 1ts affintty for coarser sediments at shallower depths where sediment resuspension presumably is more frequent. Unciola Inermis is also an epifaunal tube-builder in moderate currents but tubes are usually built into the substratum and are thus less exposed to predation. The life-history traits of $\underline{U}$. inermis are intermediate among the three amphipod species.

Frequency of sampling was dictated by the GBMP and thus could not be controlled in this study. While more frequent sampling would increase the precision of the production estimates, I do not think any 
reproductive events were missed by the sampling regime. My estimates do not account for the production of a cohort before the first date or after the last date it appears in the samples. Th1s underestimate should be small compared with the total production of the cohort over its life-span because, in the first case the mean weight of individuals is small, while in the latter case the numbers are few.

To calculate the maximum potential production underestimate, I made the following assumptions. For a juvenlle cohort first sampled at $Q(t)$, I assumed that the entire cohort recruited 1mmediately following the sampling date, $Q(t-1)$, when the cohort was not present. The lengths of these recruits were assumed to be the same as the lengths of newly recruited juveniles of each species. For adult cohorts that disappeared following $Q(t)$, I assumed that the entire cohort lived until immediately before the next sampling date, $Q(t+1)$, and that the mean length was equal to the greatest mean length observed for that species.

Using these assumptions I recalculated production for the two-year period. Maximum potential production underestimates were $7.2 \%$ for Unciola inermis, $17.2 \%$ for Ampelisca agassizi and 50\% for Ericthonius fasciatus. The potential underestimate for $\underline{U}$. Inermis is probably smaller than errors from other causes. For A. agass1zi the potential underestimate is largely accounted for by the disappearance of the $81 \mathrm{~A}$ cohort after February 1983 and the $82 \mathrm{~A}$ cohort not appearing in the samples until a mean length of $4 \mathrm{~mm}$. The large potential underestimate for E. fasciatus is mostly due to the untimely disappearance of cohort S82A after July 1982. These assumptions are for the worst-case scenario; the actual production underestimates are almost certainly less. For annual species, quarterly sampling is probably adequate; for semt-annual specles more frequent sampling (e.g. every two months) would be desirable. 
Errors in estimating the number of animals In each cohort could be the result of migration, patchiness in species distribution, variation in sampling efficlency, or from using the computer program NORMSEP. It is not always possible to distinguish these sources of error, so I shall discuss only the most glaring numerical inconsistencies.

The total number of Ampelisca agassiz1 decreased sharply in May 1982 and then Increased in July 1982 even though there was no recruitment durtng this period. Of the three spectes considered here, $\underline{A}$. agassizi is the least patchy and least mobile, suggesting that this inconsistency is a sampling problem. In May 1982 owing to heavy seas, the grab samples were taken slightly west of the true station coordinates (Battelle and WHOI 1985, Appendix A). Station 13 appears to be located on a sharp gradient in species abundance, increasing from west to east.

On the other hand, the virtual disappearance of Ericthonius fasciatus in February 1982 does not seem to be a sampling problem because Unclola Inerm1s persisted in the same grabs. Reappearance of E. fasclatus in May 1982 was probably due to colonization by adults from adjacent areas where this spectes had remained abundant. The following February E. fasclatus reached 1ts highest density. In a population open to migration, production is lost and gained to and from other areas. Therefore, production as estimated here does not apply to a closed population but Instead applies to the area of sea bottom over which the samples were taken.

The results of the bootstrap analysis agree closely with those of an independent test performed by McNew and Summerfelt (1978). These authors used NORMSEP to estimate mean length-at-age and percent composition of the component age groups in 10 collections of largemouth bass for which age was determined by counting growth rings on scales. Compared to fish 
aged by the scale method, the error of the estimated mean length-at-age averaged 3.2\%. About one-third of the frequency distributions deviated significantly from a normal distribution but this lack of fit did not greatly influence accuracy in estimating mean length. The average error of the estimated percent composition-by-age was $28 \%$; the magnitude of this error was related to the degree of asymmetry in the distribution and a large standard deviation of length.

In my bootstrap trials the coefficient of variation of mean length ranged from 1.7 to 5.6 ; the coefficient of variation of numbers ranged from 12.7 to 51.0 . Obviously mean lengths can be estimated w1th more confidence than numbers. This is not surprising because the length ewtimate varies in only one dimension while the estimated number (the area under the normal curve) also reflects the varfability of the estimated standard deviation. Consequently, growth rates derived from length-frequency data are more reliable than corresponding mortality rates. Growth rates and mortality rates are required to estimate production. If a bootstrap analysis were performed for each sample date, the variance of the production estimate could be obtained by calculating the production of each simulated cohort. Alternately, an analytical formulation of the variance could be derived, based on the variances and covarlances of all parameters in the production equation.

Despite the qualifications mentioned above, these are the first direct production estimates for benthic macrofaunal species on Georges Bank. Table 1-8 11sts production estimates of various species of marine amphipods from various locations. For ease of comparison all production rates are given in units of grams dry weight $\mathrm{m}^{-2} \mathrm{yr}^{-1}$. Where the appropriate conversion factor was not given by the author(s), I used my percent-composition data from Table 1-2. I used the data for Ampelisca 
Table 1-8. Annual production estimates of marine gammaridean amphipods ( $\mathrm{d} d w=$ grams dry weight).

\begin{tabular}{|c|c|c|c|c|c|c|}
\hline $\begin{array}{l}\text { Family } \\
\text { Species }\end{array}$ & $\begin{array}{l}\text { Locat1on and depth } \\
\text { (meters) }\end{array}$ & $\underset{\left(\mathrm{gdw} \mathrm{m}^{-2} \mathrm{yr}^{-1}\right)}{\text { Production }}$ & $\stackrel{P / B}{\left(\mathrm{yr}^{-1}\right)}$ & $\begin{array}{l}\text { Generations } \\
\text { per year }\end{array}$ & $\begin{array}{l}\text { Life-span } \\
\text { (months) }\end{array}$ & Reference \\
\hline $\begin{array}{l}\text { Ampeliscidae } \\
\quad \text { Ampelisca complex }{ }^{a}\end{array}$ & Long Island Sound (18) & 1.4 & 5 & 2 & 6 & Sanders (1956) \\
\hline A. Epinipes & $\begin{array}{l}\text { Bay of Concarneau, } \\
\text { Brittany (17) }\end{array}$ & 0.2 & 2.4 & 1 & 24 & Glemarec \& Menesguen (1980) \\
\hline A. tenuicornis & North Sea (58) & $0.2^{b}$ & 3.4 & 1 & $12-15$ & Sheader (1977) \\
\hline A. tenuicorn1s & $\begin{array}{l}\text { Bay of Morlaix, } \\
\text { Brittany (25) }\end{array}$ & 0.7 & 3.1 & 2 & 16 & Dauvin (1979) \\
\hline A. tenulcornis & $\begin{array}{l}\text { Rance Maritime, } \\
\text { Brittany (4) }\end{array}$ & $0.7-1.7$ & $3.7-4.2$ & 2 & 16 & Dauvin (1984) \\
\hline A. typica & $\begin{array}{l}\text { Bay of Morlaix, } \\
\text { Brittany (25) }\end{array}$ & .07 & 4.0 & 2 & $12-16$ & Dauvin (1984) \\
\hline A. brevicornis & Bay of Morla1x & $.04 c-0.2$ & $2.2 c-2.7$ & 2 & 12 & Dauvin $(1979,1984)$ \\
\hline A. brevicornis & $\begin{array}{c}\text { Rance Maritime, } \\
\text { Brittany (4) }\end{array}$ & $0.2-0.5$ & $2.6-2.8$ & 2 & 12 & Dauvin (1984) \\
\hline A. brev1cornis & $\begin{array}{l}\text { Bay of Concarneau, } \\
\text { Brittany (17) }\end{array}$ & 4.1 & $2.5-4.8$ & $?$ & $?$ & $\begin{array}{l}\text { Menes guen }(1980) \\
\text { in Dauvin }(1984)\end{array}$ \\
\hline A. brevicornis & North Sea (28) & $0.3-0.7$ & $3.1-4.8$ & 1 & 15 & Kle1n et al. (1975) \\
\hline A. brevicornis & Isle of Man (intertidal) & $1.3-1.7$ & $2.5-3.2$ & 1 & 15 & Hastings (1981a) \\
\hline A. araucana & Coast of Chile (65) & $5.8^{\mathrm{d}}$ & $1.9^{d}$ & 2 & 7 & Carrasco \& Arcos (1984) \\
\hline A. & $\begin{array}{l}\text { Bay of Morlaix, } \\
\text { Brittany (25) }\end{array}$ & 9.7 & 2.6 & 1 & $18-24$ & Dauvin (1979) \\
\hline
\end{tabular}


Table 1-8 cont.

\begin{tabular}{|c|c|c|c|c|c|c|}
\hline $\begin{array}{l}\text { Famfly } \\
\text { Spectes }\end{array}$ & $\begin{array}{l}\text { Location and depth } \\
\text { (meters) }\end{array}$ & $\begin{array}{l}\text { Production } \\
\left.3^{\mathrm{dw}} \mathrm{m}^{-2} \mathrm{yr}^{-1}\right)\end{array}$ & $\underset{\left(\mathrm{yr}^{-1}\right)}{\mathrm{P} / \mathrm{B}}$ & $\begin{array}{l}\text { Generations } \\
\text { per year }\end{array}$ & $\begin{array}{l}\text { Life-span } \\
\text { (months) }\end{array}$ & Reference \\
\hline $\begin{array}{l}\text { Ampelscidae cont. } \\
\text { Ampelisca sara1 }\end{array}$ & $\begin{array}{l}\text { Bay of Morlaix, } \\
\text { Brittany (25) }\end{array}$ & $.01^{\mathrm{d}-0.9}$ & $1.7 \mathrm{~d}-2.4$ & 1 & 21 & Dauvin $(1979,1984)$ \\
\hline A. agassiz1 & Georges Bank (69) & $1.3-2.8$ & $1.3-1.4$ & 1 & 24 & Th1s study \\
\hline Haploops fundiensis & Bay of Fundy $(80)$ & $0.1^{b}$ & 1.3 & 0.5 & 27 & Wild1sh (1984) \\
\hline $\begin{array}{l}\text { Aor1dae } \\
\text { Unciola Inermis }\end{array}$ & Georges Bank (84) & $2.0-3.2$ & $1.3-2.7$ & 1 & 18 & Th1s study \\
\hline $\begin{array}{l}\text { Coroph11dae } \\
\qquad \frac{\text { Coroph1um }}{\text { Insidiosum }}\end{array}$ & Corsica (brackish) & $3-60$ & $12-19.5$ & $3+$ & $1-2$ & Casablanca (1975) \\
\hline c. Insidiosum & Swedish coast (Intertidal) & $0.2-8.4 \mathrm{e}$ & $3.0-4.9 \mathrm{e}$ & $3+$ & 4 & B1rklund (1977) \\
\hline c. volutator & Swedish coast (Intertidal) & $2.5-3.8 \mathrm{e}$ & $3.2-4.4^{\mathrm{e}}$ & $3+$ & 3 & Birklund (1977) \\
\hline c․ volutator & Swedish coast (intertidal) & $1.5-24 b$ & $5.1-11.3$ & 2 & 6 & Moller \& Rosenberg (1982) \\
\hline c. volutator & Thames River Estuary (?) & 95.6 & 7.7 & $?$ & 8 & $\begin{array}{l}\text { Mossman (1978) in } \\
\text { Moller \& Rosenberg (1982) }\end{array}$ \\
\hline C. salmonis & Coast of Washington (?) & $3.6-10.7$ & $7.2-8.6$ & $3+$ & $?$ & Albright \& Armstrong (1982) \\
\hline $\begin{array}{l}\text { Haustoridae } \\
\qquad \frac{\text { Haustor1us }}{\text { canadens } 1 \mathrm{~s}}\end{array}$ & $\begin{array}{l}\text { Coast of Maine } \\
\text { (Intertidal) }\end{array}$ & $1.5^{b}$ & 1.5 & 0.5 & 24 & Donn \& Groker (1983) \\
\hline $\begin{array}{c}\text { Ischyroceridae } \\
\text { Ericthonfus } \\
\text { fasclatus }\end{array}$ & Georges Bank (84) & $1.4-3.1$ & $2.8-4.0$ & 2 & $6-8$ & This study \\
\hline
\end{tabular}


Table 1-8 cont.

\begin{tabular}{|c|c|c|c|c|c|c|}
\hline $\begin{array}{l}\text { Family } \\
\text { Specles }\end{array}$ & $\begin{array}{l}\text { Location and depth } \\
\text { (meters) }\end{array}$ & $\underset{\left(\mathrm{gdw} \mathrm{m}^{-2} \mathrm{yr}^{-1}\right)}{\text { Production }}$ & $\begin{array}{l}\mathrm{P} / \mathrm{B} \\
\left(\mathrm{yr}^{-1}\right)\end{array}$ & $\begin{array}{l}\text { Generations } \\
\text { per year }\end{array}$ & $\begin{array}{l}\text { Life-span } \\
\text { (months) }\end{array}$ & Reference \\
\hline $\begin{array}{l}\text { Melitidae } \\
\text { Casco b1gelowi }\end{array}$ & Bay of Fundy $(80)$ & $0.3^{b}$ & 2.5 & 1 & 18 & W1ldish (1984) \\
\hline $\begin{array}{l}\text { Photidae } \\
\quad \text { Phot1s reinhardi }\end{array}$ & Bay of Fundy (B0) & $0.1^{\mathrm{b}}$ & 2.8 & 1 & 18 & W1ldish (1984) \\
\hline $\begin{array}{l}\text { Phorocephalidae } \\
\text { Harpinia propinqua }\end{array}$ & Bay of Fundy $(80)$ & $.02^{f}$ & 3.1 & 1 & 14 & Wild1sh (1984) \\
\hline Rhepoxynius abron1s & Coast of oregon (5) & $0.7-1.1$ & $1.3-2.1$ & 1 & 18 & Kemp et a1. (In press) \\
\hline $\begin{array}{l}\text { Pontoporeifnae } \\
\text { Pontoporela affinis }\end{array}$ & Baltic Sea (46) & $1.9-4.4$ & $1.2-2.6$ & 0.5 & 36 & Cederwal1 (1977) \\
\hline P. femorata & Balt1c Sea (46) & $1.4-4.6$ & $0.8-2.1$ & 0.5 & 36 & Cederwall (1977) \\
\hline P. femorata & Nova Scotia $(4-10)$ & $2.8-3.4^{b}$ & $3.6-4.8$ & 1 & $12-18$ & W1ld1sh \& Peer (1981) \\
\hline$\frac{\text { Urothoe }}{\text { brevicorn1s }}$ & Isle of Man (Intertidal) & $1.3-1.9$ & $0.9-1.6$ & 0.5 & $?$ & $\begin{array}{l}\text { Hastings (1980) } \\
\text { in Hastings (1981a) }\end{array}$ \\
\hline $\begin{array}{l}\text { Talitridae } \\
\text { Talorchestia } \\
\text { margaritae }\end{array}$ & $\begin{array}{l}\text { Coast of Venezuela } \\
\text { (beach) }\end{array}$ & $660 \mathrm{~g}$ & 29.28 & $3+$ & 3 & Venables (1981) \\
\hline
\end{tabular}

a. A. diadema, A. spinipes, and A. tenuicornis.

b. These values were converted to gdw using percent composition data in Table 1-2.

c. These values were affected by the Amoco Cadiz oil spill.

d. These values were recalculated from Table 1 of Carrasco and Arcos (1984).

e. Production was calculated from May to September.

e. Production was calculated from May to September.
f. This value was converted to gdw using percent composition data for R. abronis (Kemp et al. In press)

f. This value was converted to gdw using per
g. Extrapolated from mean daily production. 
agassiz1 for all ampellscids, and Ericthonius fasclatus data for Corophium. For other specles, I assumed dry welght to equal $25 \%$ of wet weight.

Compared to other ampelisclds having one generation per year, Ampelisca agassiz1 has a lower $P / B$ but an intermediate production rate by virtue of 1ts higher mean blomass. Since Unciola Inermis and Ericthonius fasclatus are in the superfamily Corophioldae, they should be compared to Corophium. Production of $\underline{\mathrm{U}}$. $\underline{\text { Inermis }}$ and $\underline{E}$. fasclatus 18 within the range of estimates for the intertidal corophid specles. Apparently, amphipod production on Georges Bank $18 \mathrm{ss} \mathrm{h} 1 \mathrm{gh}$ as production by related near-shore spectes of similar 11fe-span.

Results of this study have implications for pollution monitoring. Most of the observed varlation in amphipod numbers can be accounted for by recruitment and subsequent natural mortality. The observation that P/B varied less than did density, blomass or production alone suggests that this ratio may be useful in monitoring the effects of pollution on marine communities. Using this method, it presently is not possible to say whether two $\mathrm{P} / \mathrm{Bs}$ are statistically different. A means of calculating confidence intervals for the production estimates is needed. 
$-48-$ 


\section{CHAPTER TWO}

FOOD SELECTION BY YELLOWTAIL FLOUNDER

\section{INTRODUCTION}

In this part of the study I analyzed the food habits of the yellowtall flounder, IAmanda ferruginea (Storer), as they relate to the distribution and abundance of benthic prey species. Fish stomachs collected by the Northeast Flsherles Center (NEFC) concurrently with benthic sampling by the Georges Bank Benthic Monitoring Program (GBMP) enabled me to compare Ingested and avallable food. I analyzed these data, the first of their kind for yellowtall flounder and for any fish species on Georges Bank, to determine whether predation patterns are predictable with respect to prey species and prey size.

Although the food hab1ts of many flsh species have been studied by examining the fishes' stomach contents (e.g. Verrill 1871, Kendall 1898), much of this information is qualitative and even anecdotal in nature. Few studies considered prey selection in relation to prey availability and fewer still tested for size-selective feeding. Existing food habits data give a static description of what eats what. Detailed and quantitative studies will lead to a better understanding of the dynamic Interactions between fish and their prey.

The yellowtall flounder is a right-handed, small-mouthed flounder (Fig. 2-1) that occurs along the eastern seaboard of North America from Labrador to Chesapeake Bay, at depths of 10 to $100 \mathrm{~m}$ (B1gelow and Schroeder 1953). It has contributed significantly to the commercial flatfish catch, primarily from southern New England and Georges Bank, since about 1935 (Clark et al. 1984). The blology and distribution of 


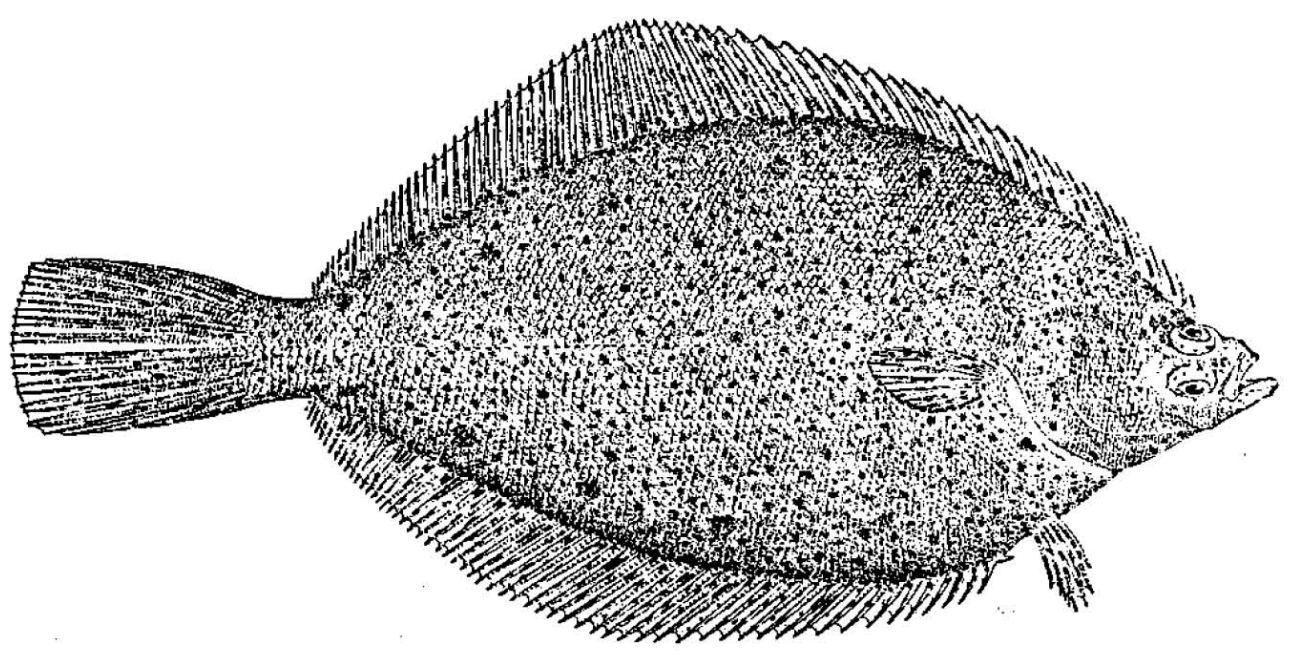

Figure 2-1. Yellowtail flounder, Limanda ferruginea (Storer). From Bigelow and Schroeder (1953). Drawing by H.L. Todd. 
yellowtall flounder were recently summarized by Lux and Ifvingston (1982). Yellowtall usually spawn for the f1rst time when they are three years old and about 30 to $35 \mathrm{~cm}$ long. The small mouth, with a single row of fine teeth and pronounced downward orientation, is adapted for benthivory.

Previous studies of yellowtail flounder food habits all showed that polychaetes and amphipods constitute the bulk of the diet. Yellowtail flounder feeding was studied by Efanov and Vinogradov (1973) on Southern New England and Georges Bank, by Pitt (1976) on the Grand Banks and by LAbey and Cole (1979) off Cape Ann, Massachusetts. Langton and Bowman (1981) analyzed the food habits of elght pleuronectiform fish, including yellowtail flounder, collected on groundfish survey cruises from 1969 to 1972. A more detailed study was made of fish stomachs collected on survey cruises from 1973 to 1976 and the data were analyzed separately by Langton (1983) and Bowman and Michaels (1984). The yellowtail flounder diet changed with length, in that polychaetes were Increasingly more important in larger fish and amphipods less so. The major prey species were polychaetes (Spiophanes bombyx, Spionidae, Lumbrineridae and Nephtydae), amphipods (Unclola spp., Byblis serrata and Leptochelrus plnguis), and decapods (Crangon septemspinosa and Dichelopandalus leptocerus).

Electivity indices measure the utilization of food types $(r)$ in relation to their abundence or availability in the environment (p). Foods constituting a larger proportion of the diet than of the available food are considered preferred; conversely, those proportionately under-represented in the diet are considered avolded. A food is eaten at random if its proportion in the diet equals its proportion in the environment. A family of electivity indicies exist, that are related 
mathematically and differ only in the particular algorithm used to calculate electivity from $r$ and $p$.

Lechowicz (1982) graphed the values of each electivity index as contours for all combinations of $r$ and $p$. He compared the strengths and weaknesses of each index with the following criteria: 1) the Index value when $r=p$ for a food; 2) the symmetry of electivity as feeding deviates from random; 3) the possible range of index vlues; 4) the 1inearity of changes in electivity over the full range of $r$ and $p ; 5)$ the sensitivity of the Index to sampling errors; 6) the statistical testability of electivity; and 7) the stability of the Index for a food type that either changes in relative abundance or occurs in combination with different food types. No one index ideally satisfies all the criteria; different indices may be appropriate in different situations.

The next section brlefly reviews studies in which fish stomach contents were analyzed in relation to prey abundance, with particular attention to methodological advances relevent to this thesis. (Food selection by demersal fish seems to be a recurring theme of graduate research - seven of the following studies are theses or were excerpted from theses.) Smith (1950) studied the food habits of eight demersal fish species in Block Island Sound. Species abundance in benth1c samples was too low to calculate an index of selection.

Ivlev, in experiments reported in his classic (1961) monograph, studied food selection, mainly by carp held in captivity and feeding in a variety of conditions. Ivlev's Index of electivity $(E)$, which has been widely used in other studies, 1s:

$$
E_{1}=\left(r_{1}-p_{1}\right) /\left(r_{1}+p_{1}\right)
$$


where $r_{1}$ and $p_{1}$ are, respectively, the proportions of prey species $i$ In the diet and environment. The advantages of $E$ are that $1 \mathrm{t}$ is bounded between +1 and -1 and 1 t 1 symmetrical about the neutral value of 0 . The disadvantages are that changes in $E$ are not linear, it is not stable if prey abundance changes, and it is not amenable to statistical testing. Levings (1974) studied the food habits of winter flounder (Pseudopleuronectes americanus) in St. Margarets Bay, Nova Scotia. Comparing the specles compositon of stomach contents to that in Ekman grab samples, he calculated $E$ values for different size classes of prey. Above a threshold size, there was a close correspondance between the size spectra of available and ingested prey. Frame (1974) studied the feeding habits of young winter flounder in a Massachusetts estuary. He calculated percent overlap between the volumes of prey species in fish stomachs and in Peterson grab samples. Percent overlap increased during the year as winter flounder made the transition from pelagic to benthic feeding.

Gabriel and Pearcy (1981) studied the feeding selectivity of Dover sole (Microstomus pacificus) off the Oregon coast. They calculated Ivlev's $E$ based on the numbers of different prey species in fish stomachs and in serially sectioned box-core samples. Prey selection was tested statistically with chi-square contingency tables. Larger sole ate larger prey and prey found deeper in the sediment. Sedberry (1980) studied the food habits of a community of fish in the Middle Atlantic Bight. He calculated Ivlev's $\mathrm{E}$ based on the numbers of different prey species in fish stomachs and In Smith-McIntyre grab samples.

In his extremely comprehensive thesis, Dauvin (1984) analyzed the stomach contents of demersal fish on the coast of Brittany, but attempted no quantitative comparison between stomach contents and benthic samples 
collected in the same area. MacDonald (1982) studied the food habits of five benthivorous fish species in Passamaquoddy Bay, New Brunswick. He used three-factor multiple analysis of varlance (MANOVA) to test for overall significant differences in prey specles composition among the five fish and Ponar grab samples, at two sites, on seven dates in one year. Using, discriminant functions analysis he assessed diet overlap and overlap between stomach contents and benthic abundance.

Schmitt and Holbrook (1984a, 1984b) studied prey selection by black surfperch (Embiotoca jacksoni) and striped surfperch (E. 1ateralis) feeding on invertebrates found on benthic turf and follose algae. These authors compared the taxonomic composition of stomach contents to that of available prey but did not calculate a prey-selection index. Using, Chesson's (1978) $\alpha$ Index they compared the sizes of avallable and ingested prey. This index is calculated as the forage ratio weighted by the sum of all forage ratios:

$$
\alpha_{i}=\left(r_{1} / p_{1}\right) / \sum_{k=1}^{n}\left(r_{k} / p_{k}\right)
$$

Here, $i$ refers to the various prey size classes. Alpha varies exponentially from 0 to 1 ; neutral selection corresponds to $1 / n$, where $n$ is the number of prey categorles. The advantages of $\alpha$ are that it is Insensitive to changes in prey abundance and it is approximately multivariate normally distributed. These properties enabled Schmitt and Holbrook to use MANOVA for comparing size selection between the two surperch species and among different size classes of black surfperch.

The studies reviewed above measured either spectes selection or size selection; none explicitly investigated the interaction between species and size preference. Andersen (1982) formulated a mathematical treatment 
of fish-stomach contents, in relation to prey abundance, which accounts for both species and size selection. Andersen's sultability coefficlent $\left(G_{1 j}\right)$ is the product of a species coeffictent $\left(p_{1}\right)$ and a size-preference coefficient $\left(g_{1 j}\right)$. The species coefficient $\left(\rho_{1}\right)$ is, by definition size-independent; $g_{1 j}$ is theoretically a lognormal function of the predator-to-prey welght ratio and may or may not be the same for different prey species. I shall show In the methods section that the suitability coefficient $\left(G_{i j}\right)$, when normalized to unity, is exactly equivalent to the alpha index calculated over prey species and prey size $\left(\alpha_{1 j}\right)$.

Ursin (1981) interpreted Andersen's mathematical formulations and discussed the requirements for fitting Andersen's model to fleld data. This model requires very complete data; in only a few cases has it been applied to fleld data. Arntz and Ursin (1981) analyzed the stomach contents of over 1,000 dab (Limanda 11manda) feeding on invertebrates in the western Baltic Sea. Their results were generally promising, desplte a few aberrant parameter estimates. The data were not completely sat1sfactory because individual prey welghts were not measured -- only the mean welght of each prey species in each stomach was available. Dekker (1983) estimated size preference parameters of North Sea cod (Gadus morhua), following Andersen's model. Because he didn't know the size-spectrum of food avallable to cod, the author assumed avallable food was constant over logarithmic size classes. Dekker's study showed that estimating the parameters of Andersen's model is feasible and pointed out the Importance of knowing the distribution of avallable prey.

Ursin and Arntz (1985a) found that the size-preference function of whiting (Merlang1us merlangus) was lognormal for whiting feeding on flsh but not invertebrates. In a companion paper, re-evaluating the 
stomach contents of dab, Ursin and Arntz (1985b) distinguished three different feeding strategles. Food selection was strongly size dependent for some prey specles, weakly size dependent for others, and size Indiscriminant for a third group. One weakness in these two studies is that the authors only considered size selection, ignoring the interaction between species selection and size selection. Secondly, because they only had mean prey weights instead of individual weights, the authors were not able to characterize the prey size distributions very well. Finally, by lumping data from all seasons together, the authors ignored seasonal changes in prey size distributions. Such seasonal changes could be responsible for the bimodal size-selection curves they observed.

In my study, data were collected with the aim of testing Andersen's model. Yellowta1l flounder are primarily benthivores, so a high degree of overlap exists between stomach contents and benthic grab samples. The number and weight of each prey spectes was measured in both sample types. In addition, individual size distributions of important prey species were measured. 
MATERIALS AND METHODS

F1sh stomachs were collected on a quarterly basis from Summer 1982 to Spring 1983, on cruises conducted by the NEFC. I particlpated on two of these four cruises: on the R/V Gloria Miche1le in August 1982 and on the Pollsh R/V Wieczno In February 1983. Stomach collection coincided as closely as possible to the dates and locations of the four benthic monitoring cruises conducted from July 1982 to May 1983. I chose GBMP Stations 5, 10 and 13 (Fig 1-1) for flsh stomach analysis because the macrofaunal assemblages differ significantly among these sites. At Stations 10 and 13 trawling was conducted in a $6.5 \mathrm{~km}$ square centered at the station coordinates (e.g. Fig. 2-2). At Station 5, to avoid disturbing the site-specific stations, trawling was conducted in the two rectangles shown in $\mathrm{F} 1 \mathrm{~g}$ 1-2.

An otter trawl, towed at three-hour intervals, usually over a 24-hour period at each station, collected the fish samples. Tow duration was generally $30 \mathrm{~min}$ at 3.0 to 3.5 knots. The net was a No. 35 bottom trawl with $18 \mathrm{~m} \mathrm{legs,} 18 \mathrm{~m}$ ground cables and $545 \mathrm{~kg}$ doors. The cod end and latter section of the upper belly were 1 ined with $13 \mathrm{~mm}$ mesh to retain small fish. Fish stomachs were excised at sea, preserved in $10 \%$ formalin in sea water and approprlately labelled.

At Battelle Marine Research Laboratory each stomach was cut longitudinally and the entire bolus removed, described according to state of digestion, and wet-welghed to the nearest $1 \mathrm{mg}$ after blotting. Stomach contents were sorted to species and enumerated. Partially digested polychaete fragments were counted if the head was present and an 1dentification could be made. The same protocol was followed for amphipods, except for the species of Unciola. The taxonomic characters 


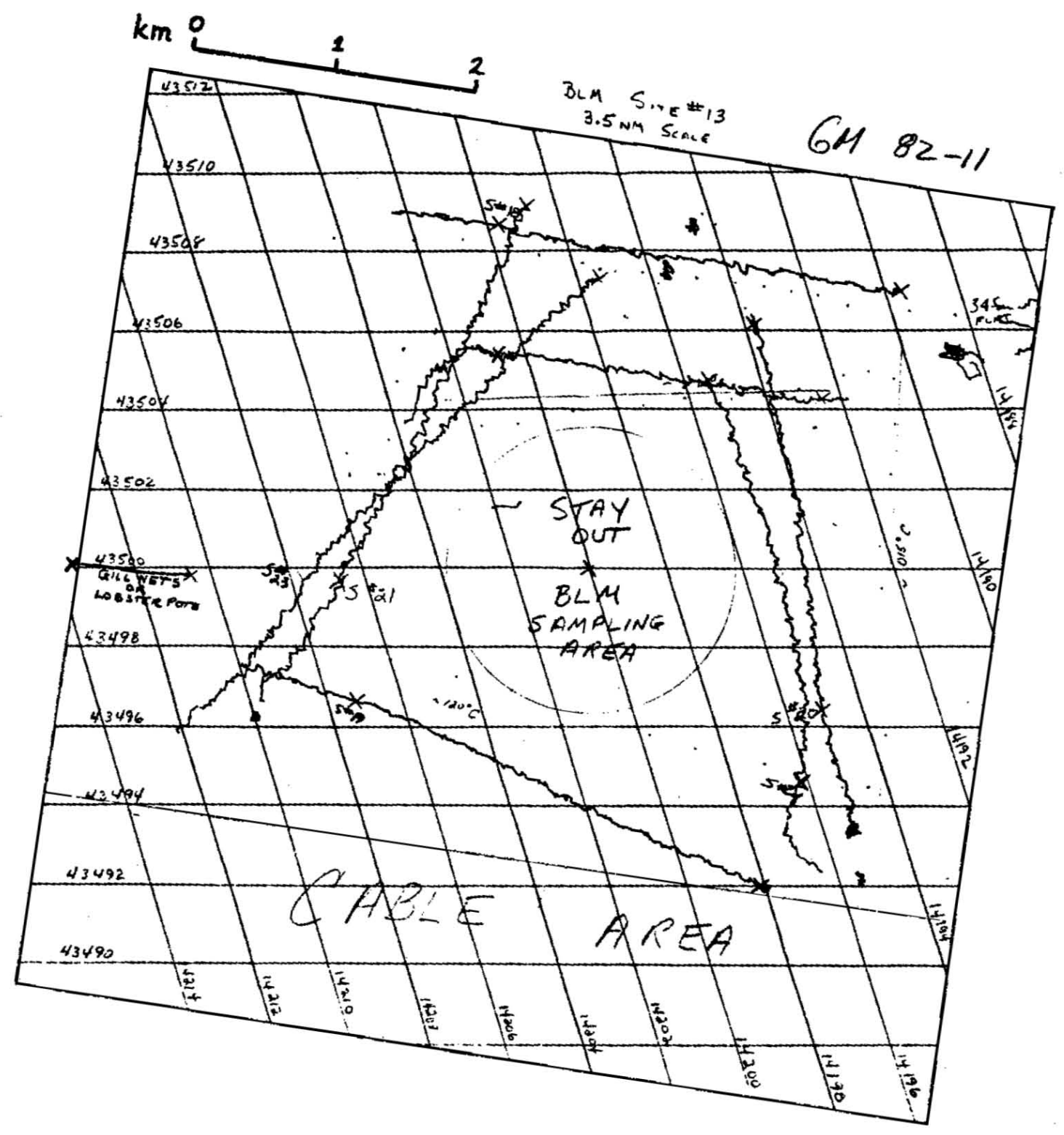

Figure 2-2.

Locations of trawls made by RV Gloria Michelle at
Station 13 in August 1982. Each wiggly line
represents one tow. 
needed for species identification in this genus include the third epimeral plate and fifth coxa. The $17 \%$ of Unctola prey lacking these characters could not be sorted to species and were recorded as Unciola spp. These Individuals were assigned to $\underline{\mathrm{U}}$. Inermis and $\underline{\mathrm{U}}$. Irrorata according to the relative proportions of identifiable individuals of the two species for that station and date. Individuals of each species were weighed together to the nearest $1 \mathrm{mg}$. Amphipod species were then sent to W.H.O.I. for length-frequency measurements; polychaete species and Echinarachnius parma were retained at Battelle for similar measurements. The benthic communities at the three sites are described in detail in Battelle and WHOI (1985); species counts and blomass data are filed In the W.H.O.I. VAX $11 / 780$ computer. In addition to the amphipod size-frequency measurements described in Chapter One of this thesis, size measurements were made of 19 polychaete and one echinoderm species (Chapters 7 and 8 in Battelle and WHOI 1985). Only two of the 19 polychaete specles were also measured in the fish stomach samples.

of the site-specific stations, Stations 5-1, 5-18, and 5-28 were the only three that were continuously sampled during the year the fish stomachs were collected. The other site-specific stations were not sampled in February 1983 because of bad weather. Since fish stomachs were collected in the area lying between Stations 5-1 and 5-28, I combined the benthic data from these two stations to calculate food selection.

To investigate the importance of size selection, size measurements were made of six prey species: Unciola Inermis and Ertcthonius fasciatus from stomachs collected at Station 5, Echinarachnius parma from stomachs at Station 10, and Ampelisca agassiz1, Chone Infundibuliformis and Levinsenta grac1l1s at Station 13. These prey species were measured in 
the same manner as those from the benthic grab samples (Battelle and WHOI, Chpts. 7 and 8 ).

Prey selection may vary, not only among fish of different lengths, but also because of behavioral differences among fish. To minimize this potential source of variation, at least for amphipod prey, I examined all stomachs of 31 to $35 \mathrm{~cm}$ long flounder for size selection. This was the most abundant flounder size class at all seasons (see Fig. 2-3). I subsampled, with a plankton splitter, stomachs containing large numbers of amphipods such that about 200 prey of each species were measured from each season.

Food selection indices were calculated to compare the specles composition of the stomach contents to that of the benthic macrofauna. I modifled Andersen's (1982) feeding model to accommodate my data. Andersen's model is based on the assumption that the weight of prey species $i$, size class $j$ in the diet $\left(s_{i j}\right)$, relative to the entire stomach contents $(S)$, is proportional to the availability $\left(\Phi_{i j}\right)$ relative to the total avallable food $(\Phi)$ :

$$
S_{i j} / S=\Phi_{1 j} / \Phi
$$

Although stomach-contents data may be biased by differential prey digestion rates, In the absence of prey-specific digestion rates I assumed the stomach contents accurately reflect the diet. Avallable food $\left(\Phi_{i j}\right)$ is defined as biomass $\left(B_{1 j}\right)$ weighted by the sultabllity coeffient $\left(G_{1 j}\right)$ :

$$
\Phi_{1 j}=B_{i j} G_{1 j} .
$$


Substituting Eq. 2.4 1nto Eq. 2.3:

$$
S_{i j} / S=B_{1 j} G_{1 j} / \sum_{k m} \sum_{m}\left(B_{k m} G_{k m}\right)
$$

Multiplication of all $\mathrm{G}$ terms by the same constant would not change Eq. 2.5. Thus, without changing the blological properties of G, I can add the constraint:

$$
\sum_{\mathbf{k m}} G_{\mathbf{k m}}=1.0
$$

Solving for $G_{1 j}$ in Eq. 2.5, and using the 1dentity in Eq. 2.6, Beyer and Sparre (1980) obtained:

$$
G_{1 j}=\left(s_{1 j} / B_{i j}\right) / \sum_{k m}\left(s_{k m} / B_{k m}\right)
$$

If prey are classified by species and size, in the diet and in the environment, an array of $G_{i j}$ values can be calculated.

The sultability coeffiecient $\left(G_{1 j}\right)$ is the product of a species coefficient $\left(\rho_{1}\right)$ and a size-preference coefficient $\left(g_{1 j}\right)$ :

$$
G_{i j}=\rho_{1} g_{1 j}
$$

Andersen (1982) hypothesized that $g_{i j} 18$ a lognormal function of the predator-to-prey weight ratio (W/w):

$$
g_{1 j}=\exp \left[-\left(\log \left(w / w_{j}\right)-n_{i}\right)^{2} / 2 \sigma_{i}^{2}\right]
$$

where $n_{1}$ is the logarithm of the preferred or optimum predator-to-prey 
weight ratio, and the variance $\sigma_{1}^{2}$ measures the breadth of size selection. Taking logarithms of Eq. 2.9:

$$
\ln \left(g_{1 j}\right)=-\left(\log \left(w / w_{j}\right)-n_{i}\right)^{2} / 2{ }_{i}^{2} \sigma
$$

gives a quadratic function of $\log \left(\mathrm{W} / \mathrm{w}_{j}\right)$ that can be fit by least squares to the observed series of $g_{i j}$ values.

The suitability coefficient is equally amenable to the situation in which prey species are counted instead of weighed. If $\mathrm{NS}_{i j}$ and $\mathrm{NB}_{i j}$ are the numbers of prey spectes 1 , size class $j$ in the fish stomachs and grab samples respectively, then:

$$
\begin{aligned}
& S_{i j}=N S_{1 j} w_{j} \text { and } \\
& B_{i j}=N B_{1 j} w_{j} \text {. }
\end{aligned}
$$

Substituting these expressions back into Eq. 2.7:

$$
G_{1 j}=\left(N S_{1 j} w_{j} / N B_{1 j} w_{j}\right) / \underset{k m}{\sum \sum}\left(N S_{k m} w_{m} / N B_{k m} w_{m}\right)
$$

All the welght (w) terms cancel, leaving:

$$
G_{i j}=\left(N S_{i j} / N_{i j}\right) / \underset{k m}{\sum \Sigma}\left(N S_{k m} / N_{k m}\right)
$$

Provided the prey are counted and welghed accurately, the suitability coefficient should be identical whether calculated on the basis of weights or numbers.

In electivity notation, 


$$
\begin{aligned}
& r_{i j}=N S_{1 j} / N S \text { and } \\
& p_{i j}=N B_{1 j} / N B .
\end{aligned}
$$

By substituting these equalities back into Eq. 2.13,

$$
\begin{aligned}
G_{1 j} & =\left(r_{1 j} / p_{1 j}\right) / \sum_{k m} \sum\left(r_{k m} / p_{k m}\right) \\
& =\alpha{ }_{1 j}
\end{aligned}
$$

It is easily shown that $G_{1 f}$ is exactly equivalent to Chesson's (1978) alpha. Th1s two-dimensional selection Index 18 flexible in that it can accommodate a situation in which not all prey specles were measured, or conversely, it can accommodate a situation in which some taxa were measured but unidentified.

In this study I calculated a Indices, using Eq. 2.15, on the basis of prey numbers rather than welghts. Although blomass is ultimately more Important to the predator, I decided, for three reasons, that prey numbers were more reliable. Firstly, the blomass data are unreliable because they are based on preserved, wet welghts and the fish-stomach material was semi-digested. Secondly, the benthic blomass data are dominated by a few large animals with hard skeletons such as Arctica 1slandica and Echinarachnius parma. These heavy animals would bias the selection indices of all other prey species. Finally, to partition the biomass data by size, I would have to convert the size-frequency distributions from numbers to weights in each size class; this would Introduce an extra step in the analysis.

$\mathrm{NS}_{1 \mathrm{f}}$ is the number of species $\mathrm{i}$, size class $\mathrm{j}$ in the stomach contents. For those prey spectes not measured I have only NS ${ }_{1}$. For prey species that were measured, I used the length-frequency 
distributions to partition the total numbers into size classes. If frs $_{\text {if }}$ is the relative frequency of species 1 , size class $j$, then:

$$
\mathrm{NS}_{i j}=\mathrm{NS}_{1} \mathrm{frs}_{i j}
$$

The size-frequency distributions measured from stomach contents should not be biased by partial digestion because they are based on length measurements that are exactly equivalent for ingested and noningested prey .

$\mathrm{NS}_{1}$ values can be calculated for individual fish stomachs, for groups of fish in a given predator size class or for the entire sample from a given station and date. The size-frequency distributions cannot be calculated for individual fish stomachs because each fish stomach did not contain enough prey to construct a representative distribution. I measured amphipods only from fish in the 31 to $35 \mathrm{~cm}$ length class.

$\mathrm{NB}_{1 j}$ is the corresponding number of species 1 , size class $j$ in benthic grab samples. Again, for those prey species not measured, I have only $\mathrm{NB}_{1}$. For prey species that were measured, I used the lengthfrequency distributions to partition the total numbers into size classes. If $\mathrm{frb}_{i j}$ is the relative frequency of species $i$, size class $j$ :

$$
\mathrm{NB}_{1 \mathrm{j}}=\mathrm{NB}_{1} \mathrm{frb}_{1 j}
$$

Values of $\mathrm{NB}_{1}$ can be calculated for individual replicates or for the sum of all replicates. Size-frequency distributions were not obtained for each benthic replicate but I have assumed the distributions I did obtain represent each replicate in the sample (see Chapter One). 
In the first instance, I calculated $\mathrm{NS}_{1}$ and $\mathrm{NB}_{1}$ by summing over all fish stomachs and all benthic replicates from a given station and date, respectively. For Eq. 2.15 to remain valld, it must be assumed that those species not measured are neutrally selected for size.

FIsh stomachs and benthic grabs are obviously different types of samplers; the Important question 1s, to what extent do they sample the same populations? The sets of species in the fish stomachs (FS) and in the benthic grabs (BG) do not completely overlap, as shown below:

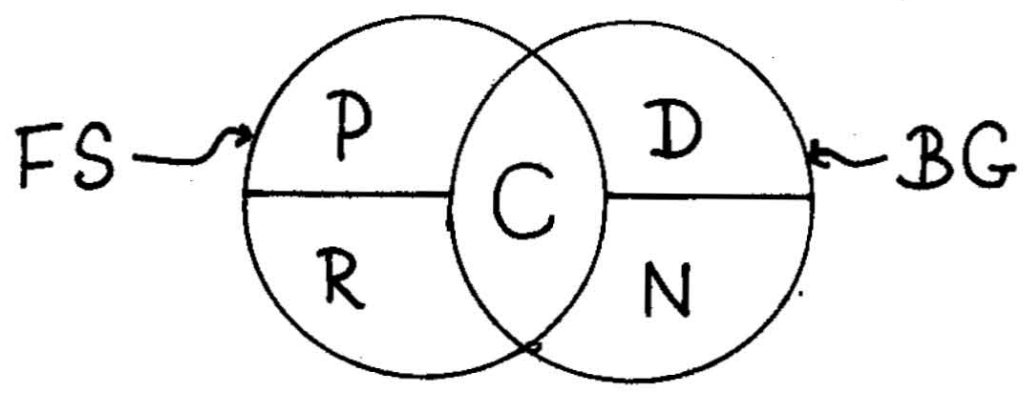

C is the set of species appearing both in the diet and in the environment. $C$ should be as large as possible and in the ideal case it should be a subset of BG. $P$ is the set of pelagic species eaten by the fish but unavallable to the grab sampler. If $P$ is large, selectivity indices for the benthic species (set C) will be blased downwards. R is the set of benthic species that do not appear in grab samples because they are rare or because they avoid the grab. The first case is true positive selection by fish; in the second case electivity would be overestimated. D is the set of benthic species unavallable to fish, for example because they burrow deeply. If D is large, selectivity for species in set $C$ will be artificlally high. $N$ is the set of species available to the fish but truly selected against, for example because they are the wrong size. 


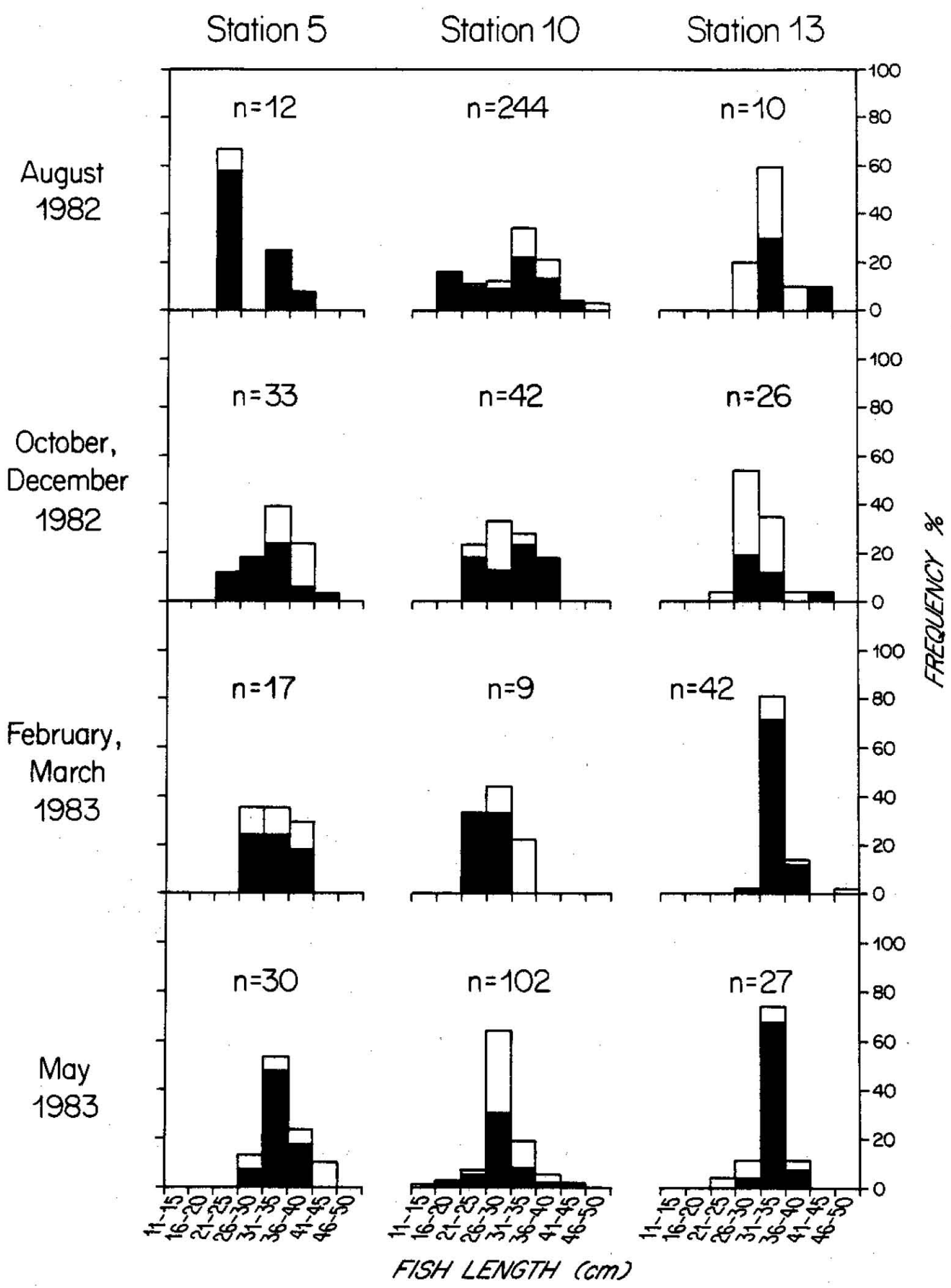

Figure 2-3. Length distributions of yellowtail flounder collected for stomach analysis. Solid bars represent full stomachs; empty bars, empty stomachs. 
RESULTS

The numbers of fish stomachs collected are 1lsted, by species, station and season in Table 2-1. (Fish species that are primarily pelagic feeders are excluded from this 1ist.) From this assemblage of demersal fish, I chose yellowtall flounder for stomach analysis because it is relatively abundant, feeds almost entirely on benthic macrofauna and is a commercially 1mportant specles. In this study, a total of 594 yellowtall flounder stomachs were examined. The length distributions of these fish are plotted in FIg. 2-3. The majority of the yellowtail flounder were between 26 and $35 \mathrm{~cm}$ long, which corresponds to an age of three years (Lux and Livingston 1982). Because of the small sample sizes and because most of the flounder occurred in only two of the size classes, I was unable to examine the potentlal effect of predator length on diet composition.

The stomach contents of these fish are tabulated, by numbers and by welght, in Appendix B. At each station and date, a few prey species constituted the bulk of the yellowtall flounder diet. To illustrate the dominant prey species (Figs. 2-4 and 2-5) I summed the stomach contents over the four seasons. Figure 2-4 shows the five most numerous prey species of yellowtall flounder at each station. These top five prey spectes accounted for $96 \%, 70 \%$ and $89 \%$ of the total 1dentiflable prey at Stations 5, 10 and 13, respectively. Figure 2-5 shows the top five prey species at each station on a weight basis. These species (which are slightly different from those in F18. 2-4) accounted for $83 \%, 82 \%$, and $80 \%$ of the total welght of identifiable stomach contents at Stations 5 , 10 and 13 , respectively. 
Table 2-1. Numbers of stomachs collected from benthic-feeding fish.

\begin{tabular}{|c|c|c|c|c|c|c|c|c|c|c|c|c|c|}
\hline \multirow[b]{2}{*}{ F1sh Species } & \multicolumn{2}{|c|}{ August } & \multirow{2}{*}{$\begin{array}{r}1982 \\
13\end{array}$} & \multicolumn{4}{|c|}{ Date and Station } & -March & \multirow{2}{*}{$\begin{array}{l}1983 \\
13\end{array}$} & \multicolumn{3}{|c|}{ May 1983} & \multirow[b]{2}{*}{ Total } \\
\hline & 5 & 10 & & 5 & 10 & 13 & 5 & 10 & & 5 & 10 & 13 & \\
\hline Winter skate & - & - & - & 5 & 58 & 26 & 1 & 26 & 1 & 1 & 92 & - & 210 \\
\hline Little skate & 38 & 48 & 3 & 55 & 123 & 41 & 133 & 85 & 48 & 340 & 247 & 21 & 1182 \\
\hline Red hake & 226 & 82 & 196 & 78 & 1 & 42 & 3 & 3 & 31 & 15 & 1 & 137 & 815 \\
\hline Haddock & - & - & - & 1 & - & - & - & 6 & 1 & 5 & 22 & 1 & 36 \\
\hline Ocean pout & - & - & 3 & - & - & - & 4 & - & 41 & 56 & 6 & 6 & 116 \\
\hline Yellowtail flounder & 12 & 244 & 10 & 33 & 42 & 26 & 17 & 9 & 42 & 30 & 102 & 27 & 594 \\
\hline Witch flounder & 1 & - & 66 & - & - & - & - & - & 3 & 2 & - & 14 & 86 \\
\hline American plaice & - & - & - & - & - & - & - & 1 & - & - & - & 1 & 2 \\
\hline Gulf Stream flounder & 3 & - & 1 & 14 & 11 & 24 & 8 & - & 3 & 73 & 13 & 6 & 156 \\
\hline Winter flounder & - & - & 1 & - & - & 3 & - & - & - & - & - & - & 4 \\
\hline Longhorn sculpin & 3 & 4 & $=$ & 25 & 6 & - & 2 & - & 5 & 5 & 39 & - & 89 \\
\hline Northern sea robin & - & - & - & - & - & 10 & 3 & - & 1 & 1 & - & 1 & 16 \\
\hline
\end{tabular}



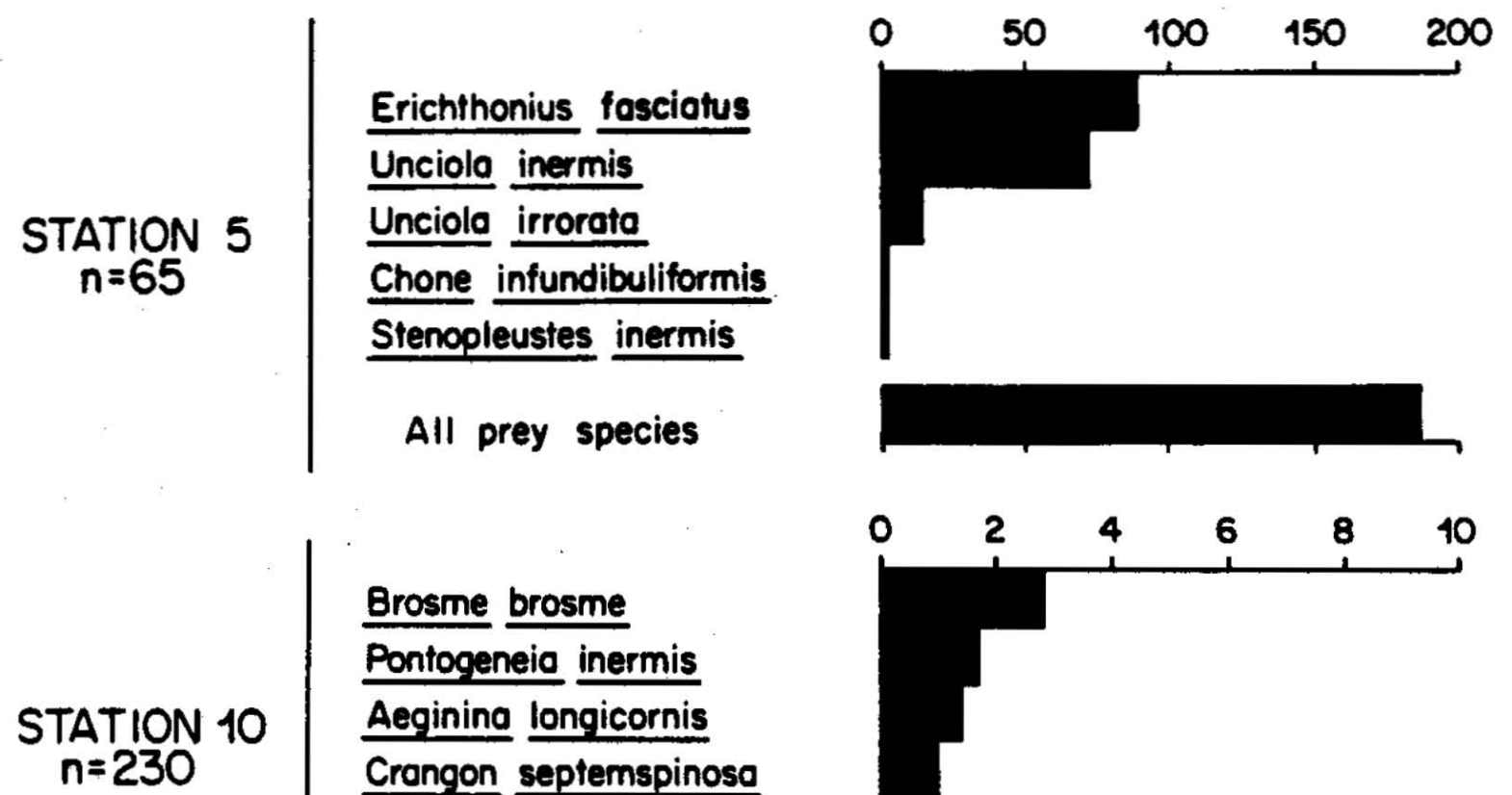

Brosme brosme

Pontogeneio inermis

Aeginina longicornis

Crangon septernspinoso

Pogurus spp. (juv.)

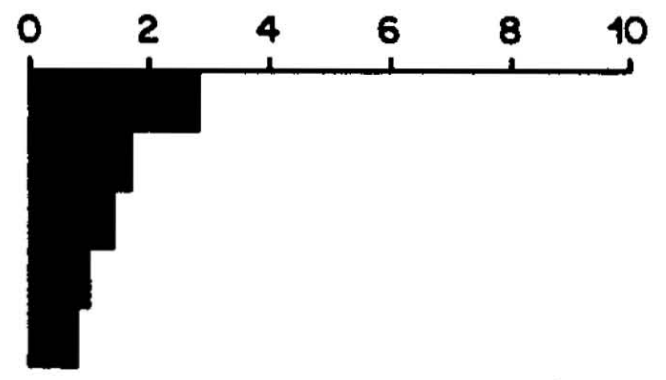

All prey species
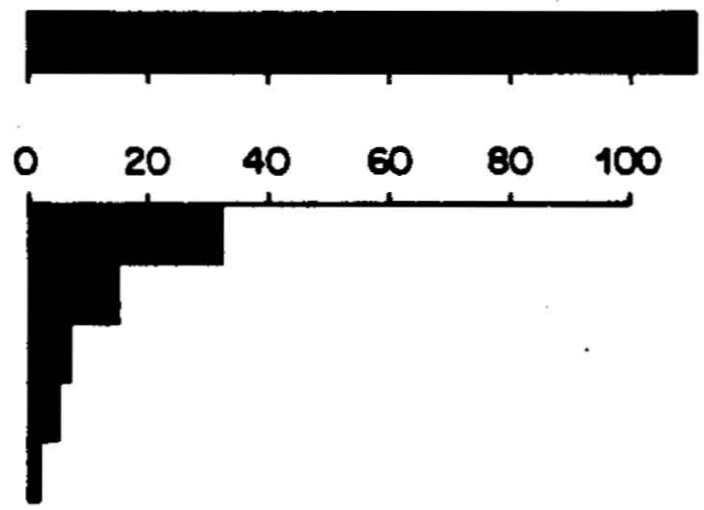

All prey species

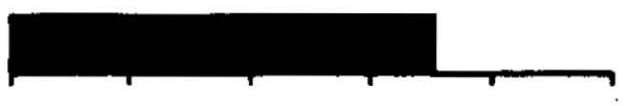

mean no. per stomach

Figure 2-4. Five most numerous prey species of yellowtail flounder at Stations 5, 10 and 13. Data are weighted means of four (quarterly) collecting cruises. 
At Station 5 the diet was dominated by tubicolous amphipods and polychaetes. Lumbrineris fragilis was important on a welght basis although only elght of these large worms were eaten. Out of 64 prey specles, 52 were also collected in benthic grab samples (set C), three were pelagic (set $P$ ) and nine, although benthic were not found in the grab samples (set $R$ ). The 12 species in sets $R$ and $P$ constituted an insignificant proportion of the total diet (see Appendix B). Pelagic prey were more important at Station 10 where the diet was dominated by fish larvae, amphipods, shrimps and crabs. Large benthic animals, such as Cerlanthus borealis, Echinarachnius parma and L. fragllis, constituted much of the biomass. Of 50 prey specles, 31 were in set $C$, four in set $P$ and 15 in set $R$. Of the 19 species in sets $P$ and $R$, nine were important components of the flounder diet (Appendix B). As a result, selectivity at Station 10 for species in set $\mathrm{C}$ will be biased downwards. At station 13 the diet was dominated by amphipods numerically, and by polychaetes on a weight basis. Of 56 prey species, 47 were in set $C$, two in set $P$ and seven in set $R$. None of the nine specles in sets $P$ and $R$ were important components of the diet (Appendix B).

Fish caught at Station 5 had the highest mean number of prey per stomach, followed in turn by those caught at Station 13 and 10 . Because the mean weight of stomach contents was only slightly greater at Station $5(707 \mathrm{mg})$ than at Station $13(680 \mathrm{mg})$ and Station $10(528 \mathrm{mg})$, most of the differences in prey number are due to differences in mean prey welght. On the average, flounder ate larger prey at Station 10 (54 mg) than at Station $13(10 \mathrm{mg})$ or Station $5(4 \mathrm{mg})$.

Seasonal variations in flounder food hablts were illustrated in the GBMP Year 2 Report (Battelle and WHOI 1984, F1g. 69). At Station 5 the same prey specles dominated the diet at all seasons. In contrast, there 

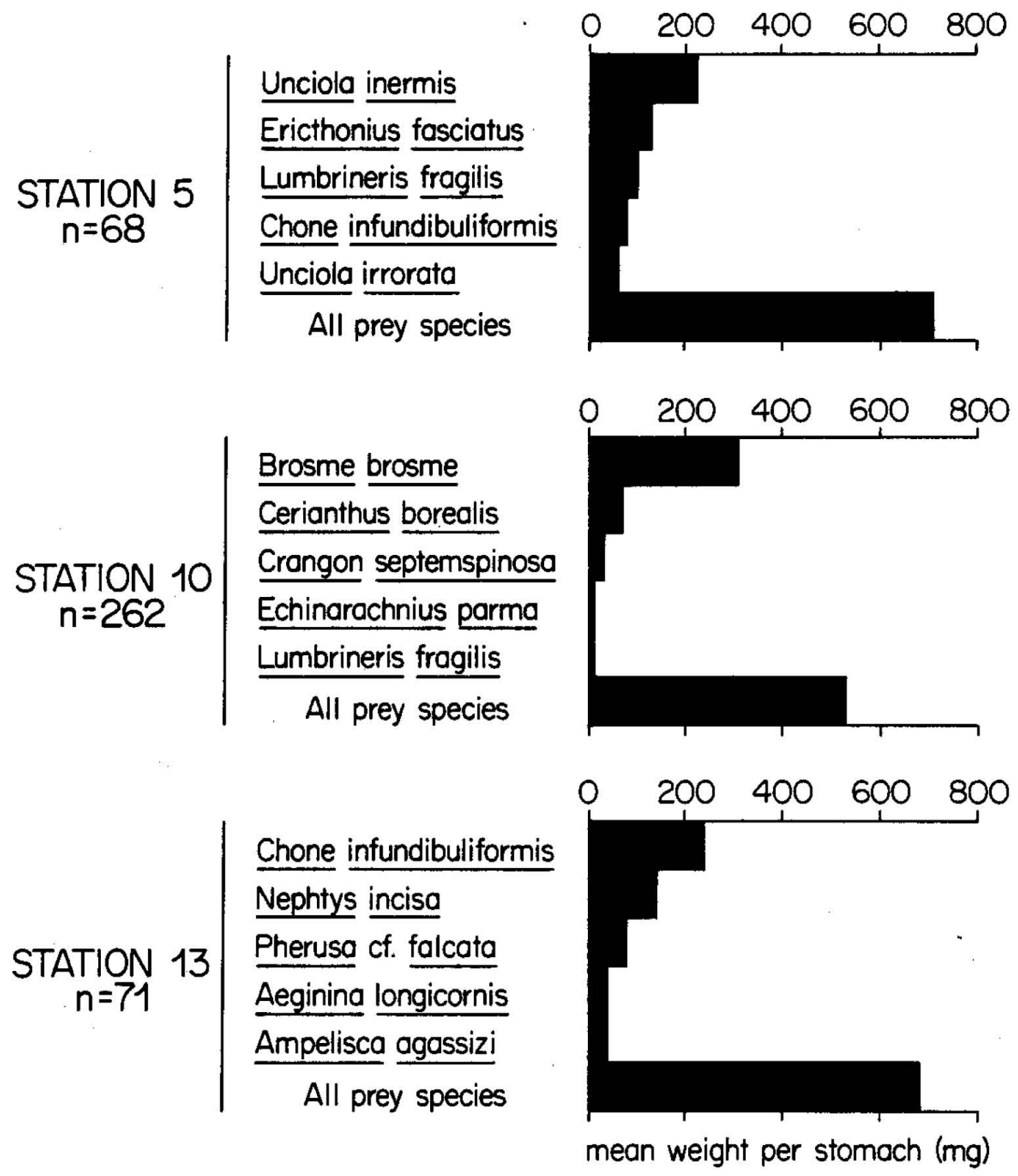

Figure 2-5. Five most 1mportant prey species of yellowtail flounder in units of wet weight. Data are weighted means of four (quarterly) collecting cruises. 
was considerable seasonal variation in the diet at Station 10 . The diet was dominated by larvae of cusk Brosme brosme in August, by the shrimp Crangon septemspinosa in the fall and winter, and by the amphipods Pontogenela 1nermis and Aeginina 1ongicornis in May. At Station 13 the diet was relatively constant except for the eplfaunal caprellid, A. 1 longicornis, which was eaten in great numbers in winter but much less at other times of the year.

I compared the size-frequency distributions generated from the fish-stomach contents to those from benthic grab samples, with all frequenctes expressed as percentages. Due to small numbers of individuals collected, it was not possible to generate size-frequency distributions for all four seasons for all six prey spectes measured; in some cases it was necessary to pool the size data over four seasons.

I generated length-frequency distributions for Ampelisca agassizi found in flounder stomachs at Station 13 for fall, winter and spring cruises. The small number of stomachs collected during the summer cruise ylelded insufficient $A$. agassizi to measure. Size distributions generated from the grab samples and fish stomachs from May 1983 are compared in Figure 2-6. Flounder neglected the small 3 to $6 \mathrm{~mm}$ A. agassizi, selecting the 6 to $8 \mathrm{~mm}$ size range.

Length-frequency distributions of Unciola inermis and Ericthonius fasciatus found in flounder stomachs at Station 5 were obtained for a11 four seasons. I combined the size distributions from grab samples collected at Stations 5-1 and 5-28 by calculating the average percent in each size class, weighted by the densities at each station. The distributions from May 1983 are shown in Figures 2-7 and 2-8. This was a period of recruitment for both $\underline{\mathrm{U}}$. Inermis and E. fasclatus. Again, flounder selected against the juveniles, feeding most heavily on adults. 


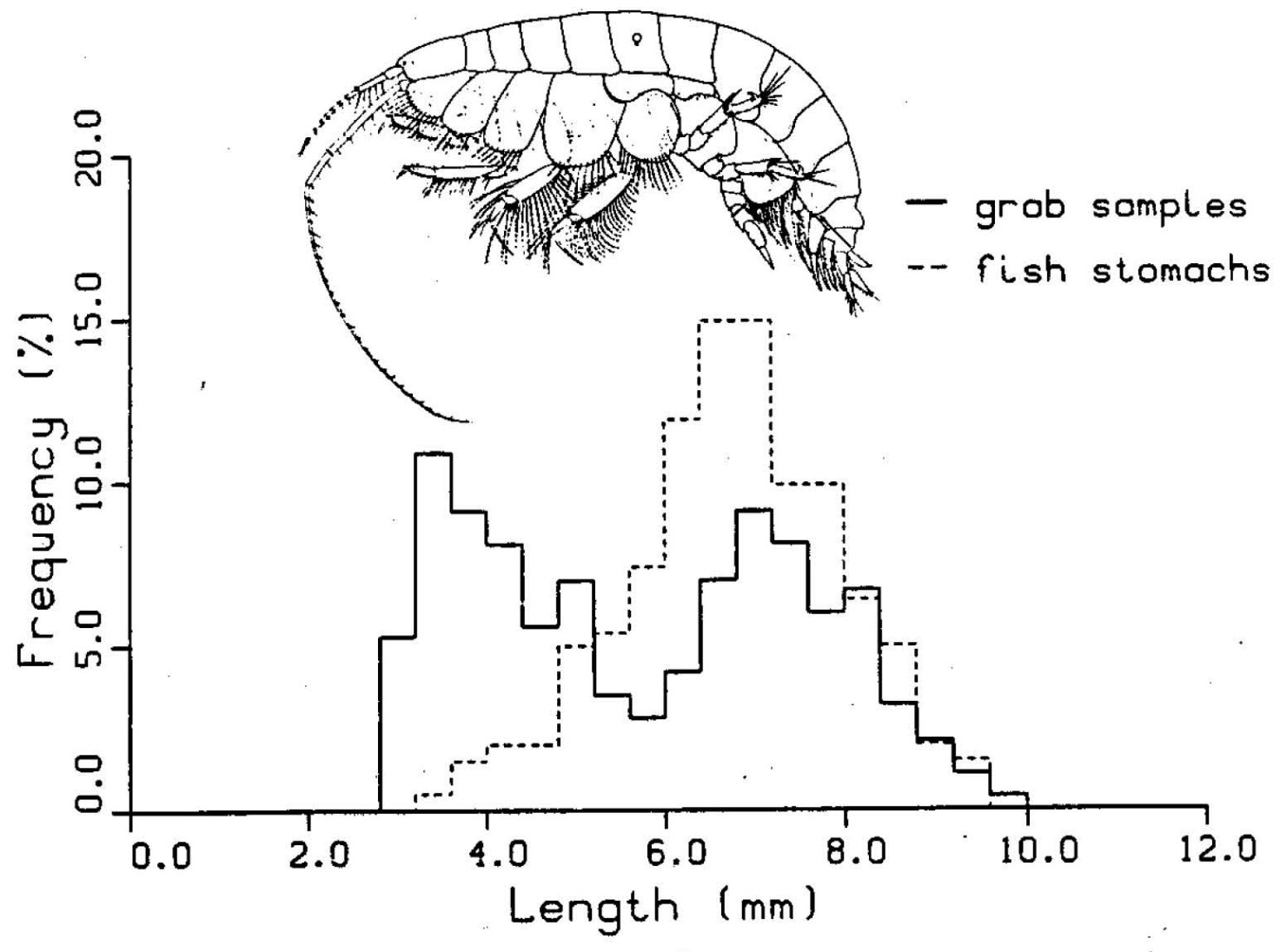

Figure 2-6. Ampelisca agassizi length-frequency distributions at Station 13 in liay 1983. The benthic distribution is based on 285 amphipods, which were captured in three grab samples and measured. The ingested distribution is calculated from 214 amphipods removed from 10 yellowtail flounder stomachs and measured. 


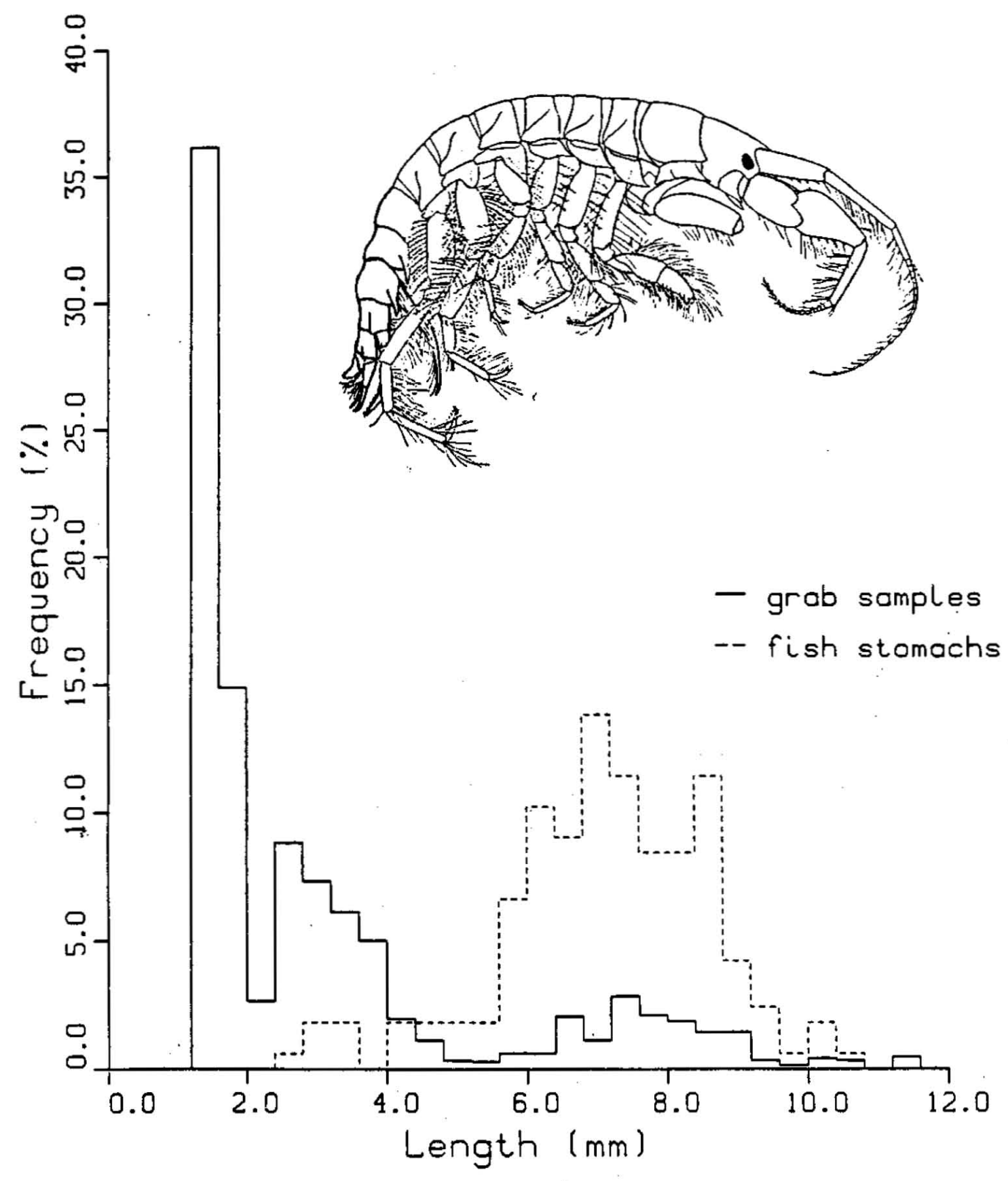

Figure 2-7. Unciola inermis length-frequency distributions at Station 5 in May 1983. The benthic size distribution is a weighted mean of 215 amphipods from Station 5-1 and 220 amphipods from Station 5-28. The ingested distribution is based on 167 amphipods removed from 13 yellowtail flounder stomachs and measured. 


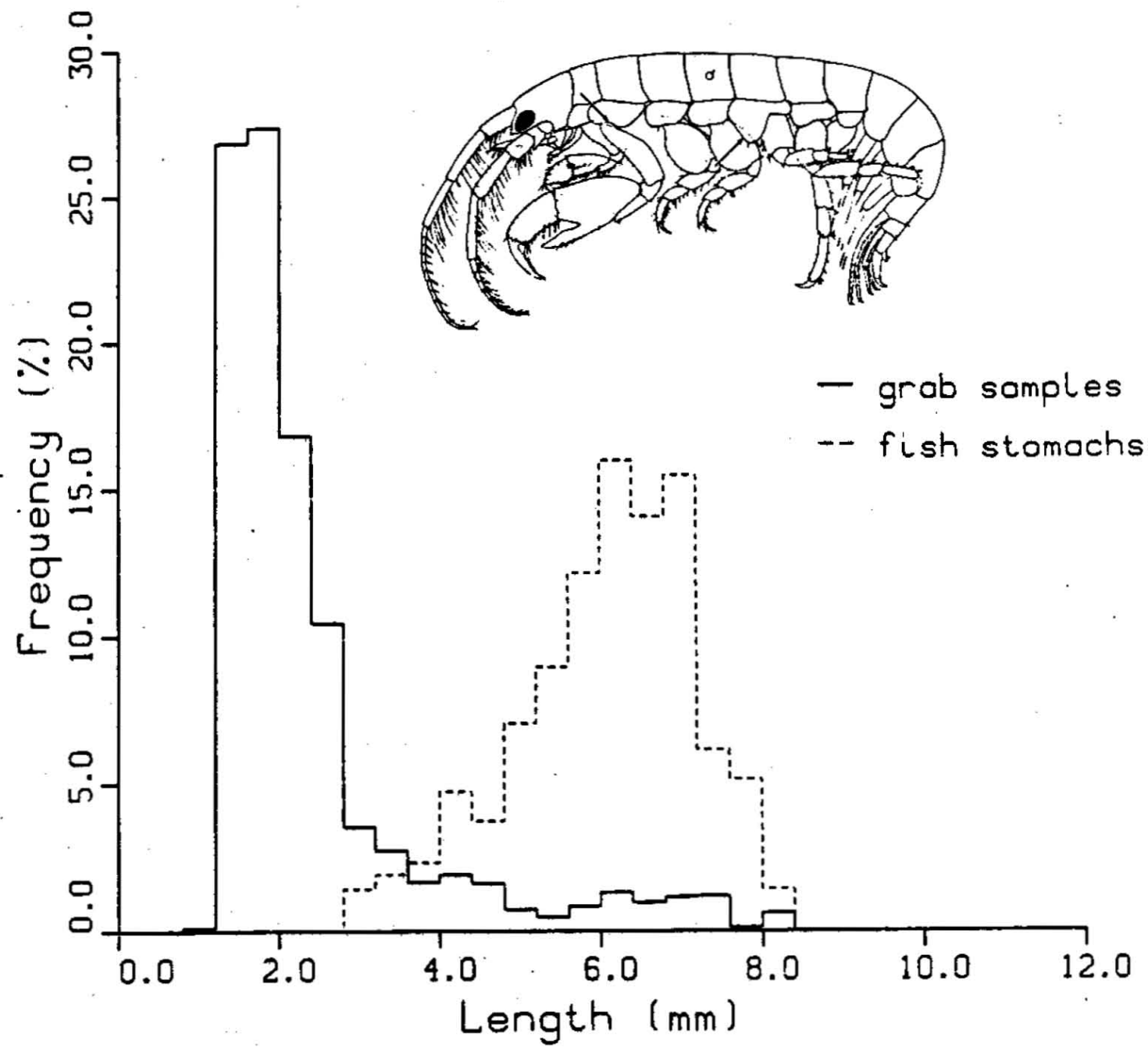

Figure 2-8. Ericthonius fasciatus length-frequency distributions at Station 5 in May 1983. The benthic size distribution is a weighted mean of 157 amphipods from Station 5-1 and 203 amphipods from Station 5-28. The ingested distribution is based on 214 amphipods taken from 10 yellowtail flounder stomachs and measured. 
Although Echinarachnius parma is numerically dominant at Station 10, the small number of sand dollars ingested by flounder made it necessary to pool the length-frequency data from all cruises (FIg. 2-9). This is justiflable because, as can be seen from F1gure 98 in Collie and Curran (1985), the sand dollars grew only slightly during this perlod. The benthic grab samples contained juveniles in the 0 to $2 \mathrm{~mm}$ size class and larger sand dollars between 10 and $25 \mathrm{~m}$ long. Yellowtail flounder, when feeding on sand dollars, almost exclusively chose 6 to $12 \mathrm{~mm}$ individuals -- even though this size range was rare in the benthos.

Chone infundtbuliformis, in contrast to E. parma, was strongly selected for by flounder despite the former's low abundance in the benthos. Because few of these animals were found in the grab samples, and because the sizes of ingested C. Infundibuliformis did not appear to vary with season, I pooled the length-frequency data from all cruises and plotted the distributions in Fig. 2-10. If one allows for the differences in sample sizes, the fish-stomach and grab-sample lengthfrequency distributions are very similar.

The slze measurement used for Levinsenta gracllis was not length but setiger number as estimated using the regression equation in Table 14 of Battelle and WHOI (1985). Although $\underline{L}$. gracilis was one of the most numerous species in the grab samples from Station 13, it was not found in flounder stomachs collected in summer and fall 1982. The size-frequency data from February and May 1983 are pooled and plotted in Fig. 2-11. The grab-sample size-frequency data are skewed towards higher setiger numbers. Flounder fed on the same size range as occurred in the benthos, but the fish-stomach size-frequency distribution is more normally distributed and therefore it appears that the fish selected smaller-sized worms. 


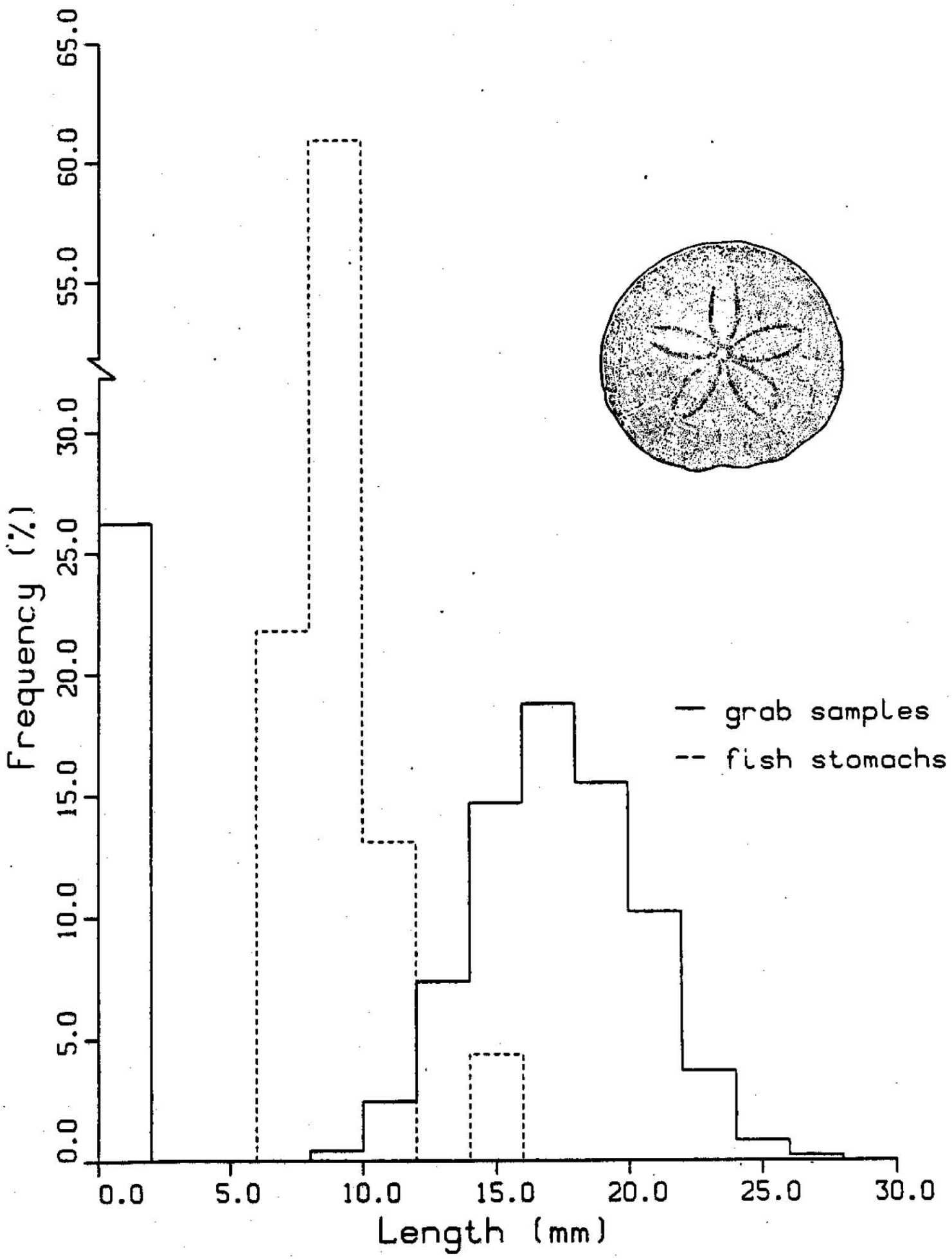

Figure 2-9. Echinarachnius parma length-frequency distributions at Station 10 from July 1982 to May 1983. The benthic distribution is calculated from 492 sand dollars; the ingested distribution is based on 23 sand dollars found in 11 yellowtail flounder stomachs. 


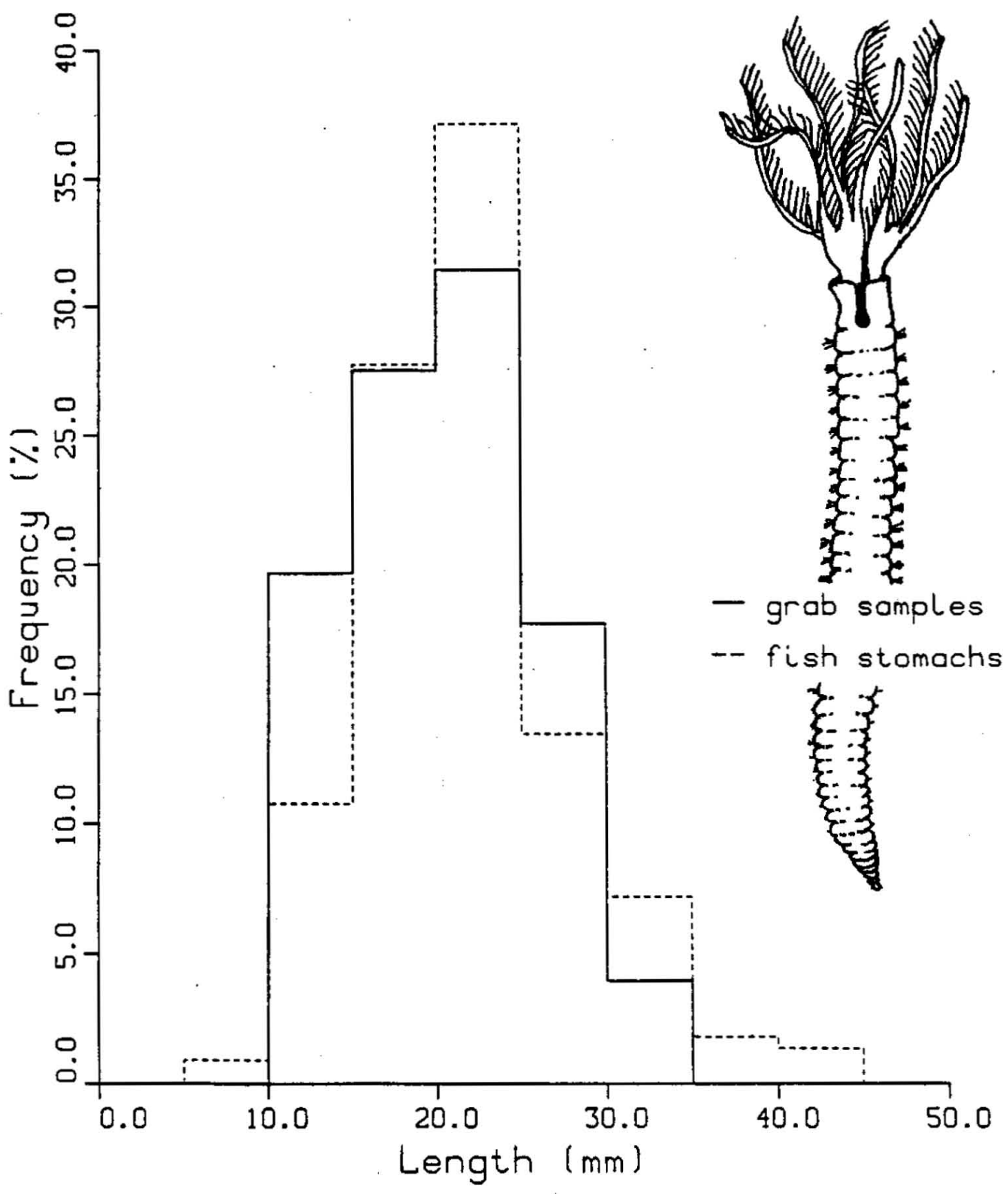

Figure 2-10. Chone infundibuliformis length-frequency distributions at Station 13 from July 1982 to May 1983. The benthic distrbution is based on 51 worms; the ingested distribution is generated from 224 worns found in yellowtail flounder stomachs. 


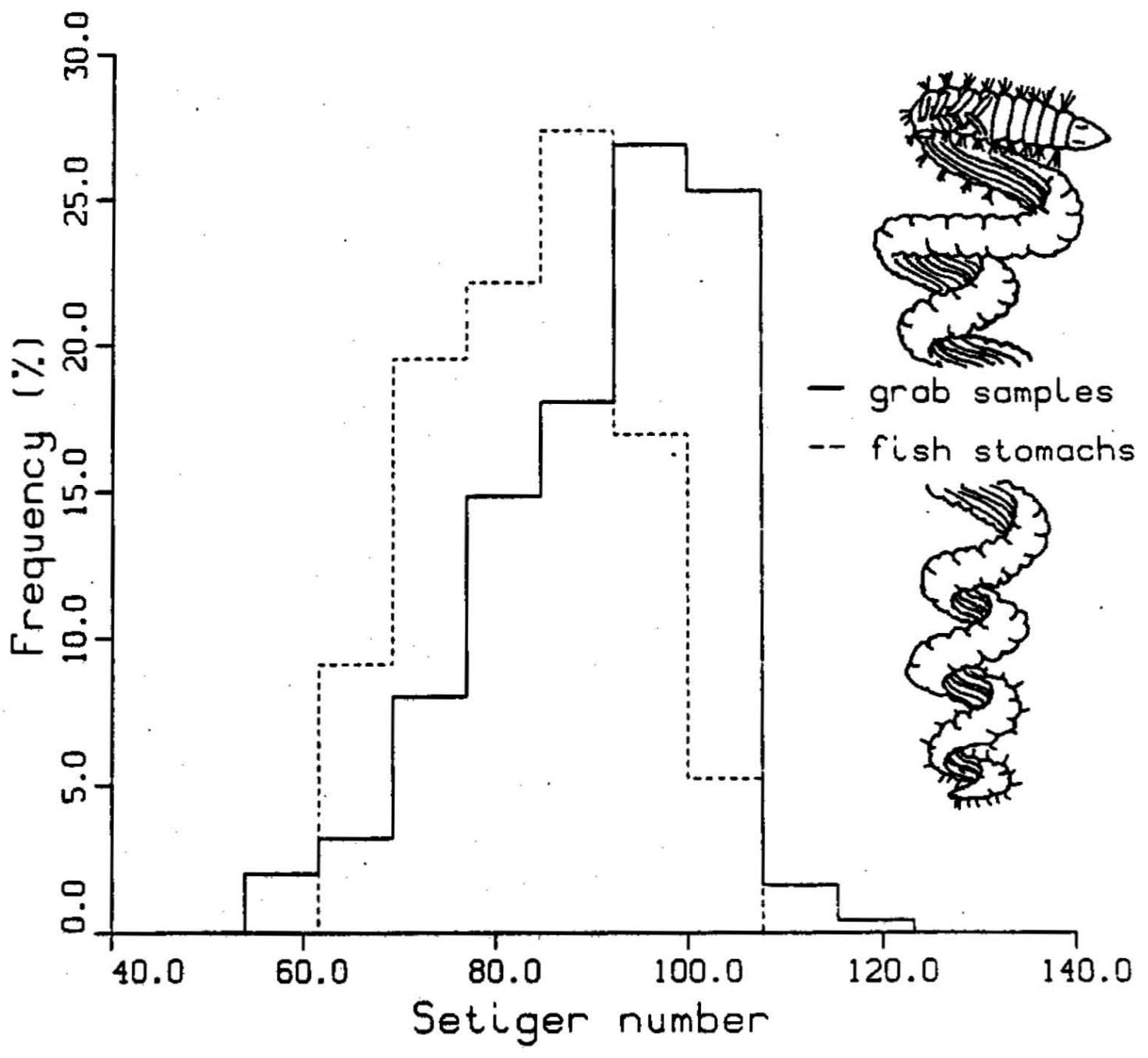

Figure 2-11. Levinsenia gracilis size-frequency distributions at Station 13 from February to May 1983. The benthic distribution is based on 250 worms; the ingested distribution comes from 77 worms eaten by yellowtail flounder. 
I calculated $\alpha$ selectivity indices to determine whether changes in prey composition reflect seasonal changes in benthic community composition. Constant $\alpha$ for a given prey spectes indicates that fish feeding mirrors changes in prey abundance; varlable $\alpha$ implies that prey suitability or avallability changed during the year.

As a first step in calculating selection indices, I calculated $\alpha_{1}$ on the basis of prey species only, disregarding the size-frequency data. I did this to compare selectivity among those prey species not measured. Spectes in sets $P$ and $R$ (pelagic and rare benthic) enter into the calculation of $r_{1}$ in Eq. 2.15, but $\alpha_{1}$ is undefined for these species because $p_{1}$ is zero. Species in groups $D$ and $N$ (benthic species not eaten by fish) enter into the calculation of $p_{1}$, but $\alpha_{1}$ is zero for these species. The $\alpha$ value corresponding to neutral selection $181 / n$, where $\mathrm{n}$ is the number of prey species. I took $\mathrm{n}$ to be the size of set $\mathrm{C}$ : those species found both in the flsh stomachs and in the grab samples during at least one season. This gives a slightly higher neutral value than if $n$ were the size of set $B G$ : the total number of species in the benthic grab samples.

Seasonal $\alpha$ Indices for prey species dominating the diet at Stations 5, 10 and 13 are shown in Figs. 2-12, 2-13 and 2-14, respectively. Pelagic prey were important in the diet at Station 10 , but $\alpha$ is undefined for these specles. The dashed line in each subplot indicates the $\alpha$ value corresponding to neutral selection. This value is the same for all species and seasons at a given station but varies slightly among stations because the numbers of prey species are different. When examining these plots one must remember that $\alpha$ is based on proportions and the sum of for each season is unity. Therefore, an increase in $\alpha$ for one species results in a decrease for other species and it is impossible to determine 

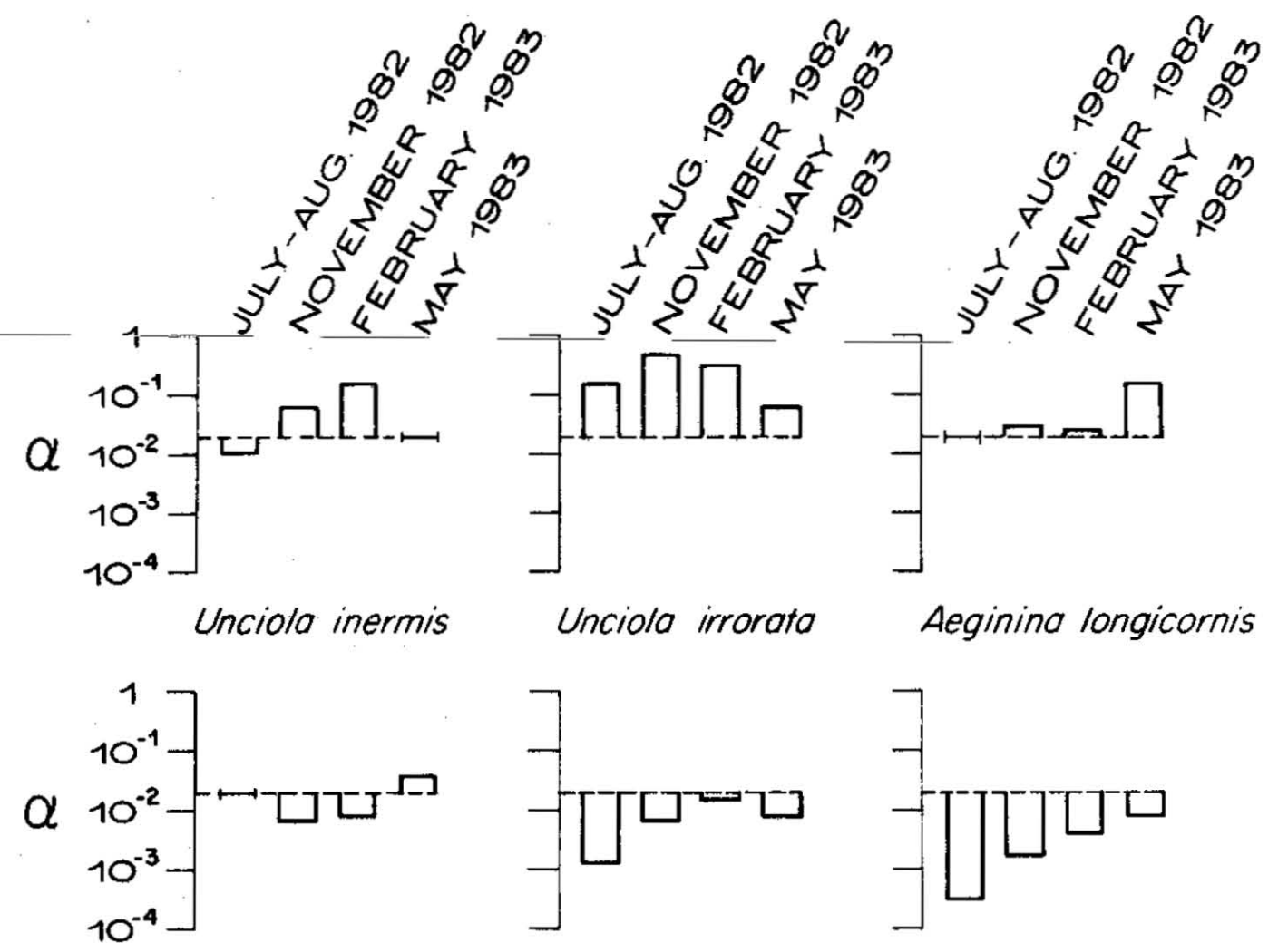

Unciola irrorata

Aeginina longicornis

Ericthonius fasciatus Stenopleustes inermis
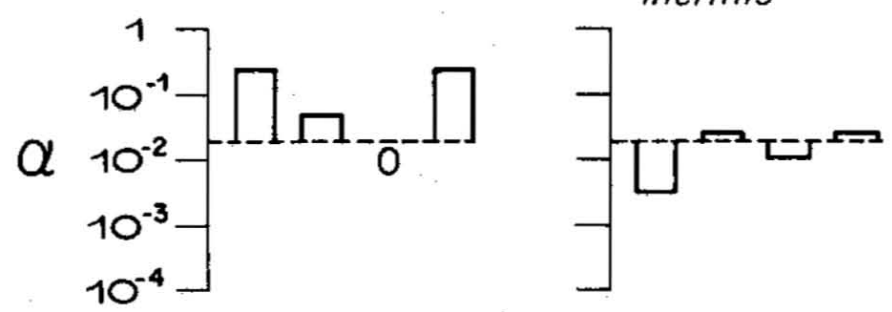

Chone infundibuliformis Chone duneri

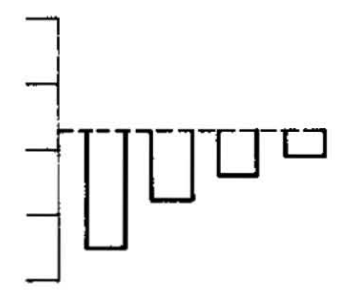

Amphipholis squamato

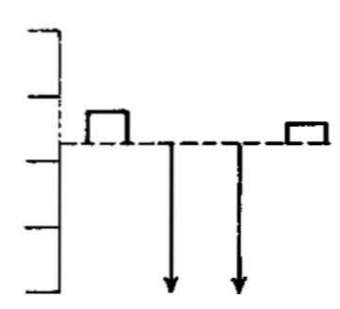

Lumbrineris frogilis
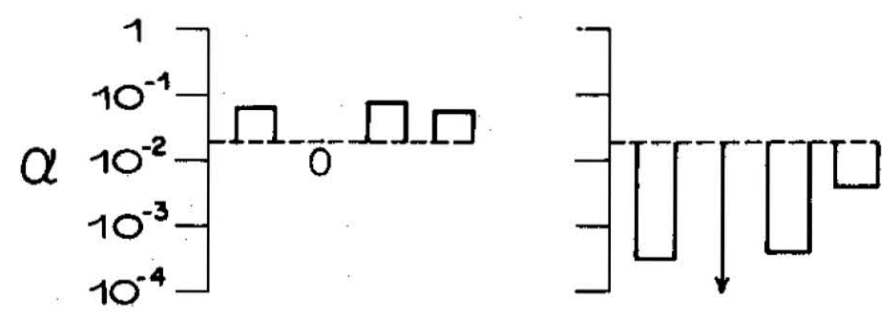

Clymenura polaris

Euclymene sp. A

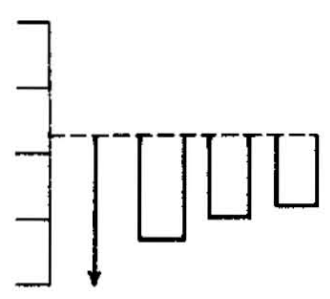

Agloophamus circinata

Figure 2-12. Yellowtall flounder selectivity for benthic prey at Station 5. The dashed line in each subplot is the value for neutral se1ection. Arrows indicate that the prey species was present in benthic grab samples but not eaten by flounder on that date; $\alpha$ is zero in this case. Zeros below the dashed line indicate that the prey specles was not found in benthic grab samples on that date; in this case $\alpha$ is undefined. 


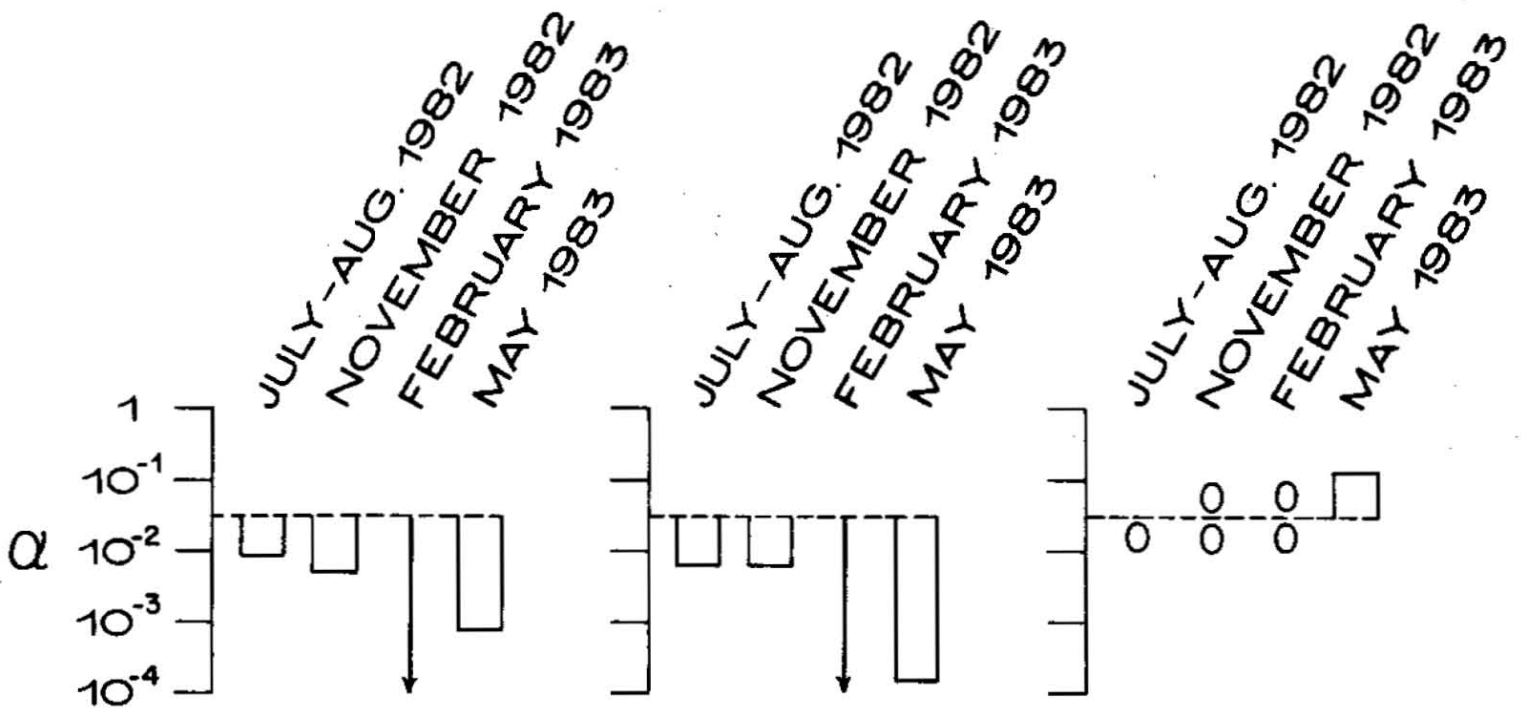

Rhepoxynius hudsoni Protohaustorius Aeginina longicornis

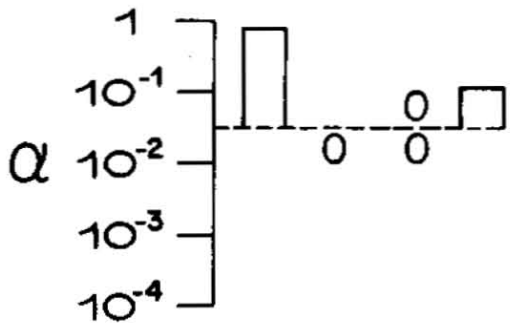

Pagurus spp (juv.)

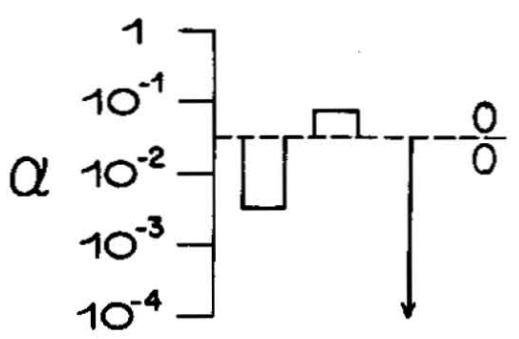

Nephtys bucera

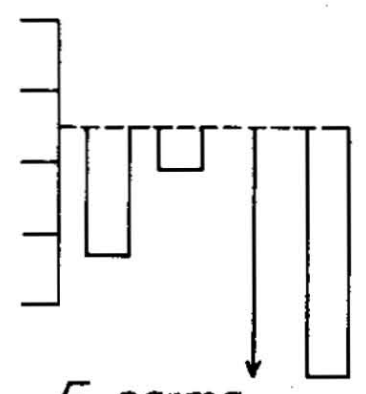

E. parma

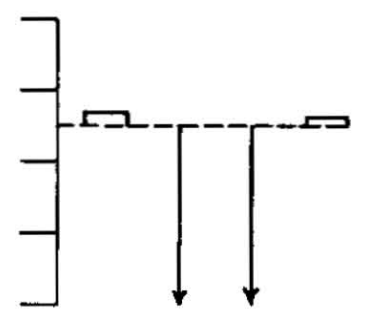

Sthenelais limicola

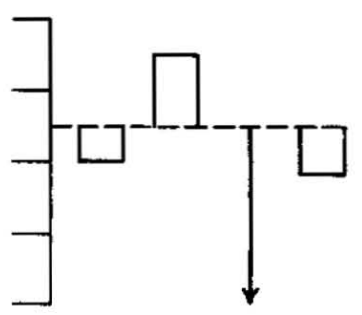

Cirolana polita

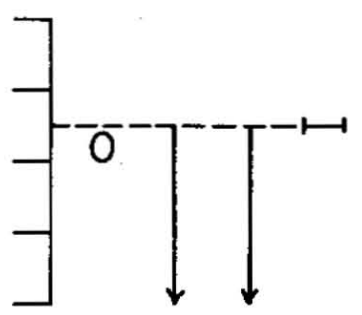

Lumbrineris fragilis

Figure 2-13. Yellowtail flounder selectivity for benthic prey at Station 10. The dashed line in each subplot is the value for neutral selection. Arrows indicate that the prey species was present in benthic grab samples but not eaten by flounder on that date; $\alpha$ is zero in this case. Zeros below the dashed line indicate that the prey species was not found in benthic grab samples on that date; a zero above the dashed line indicates that the prey species was not eaten on that date. 


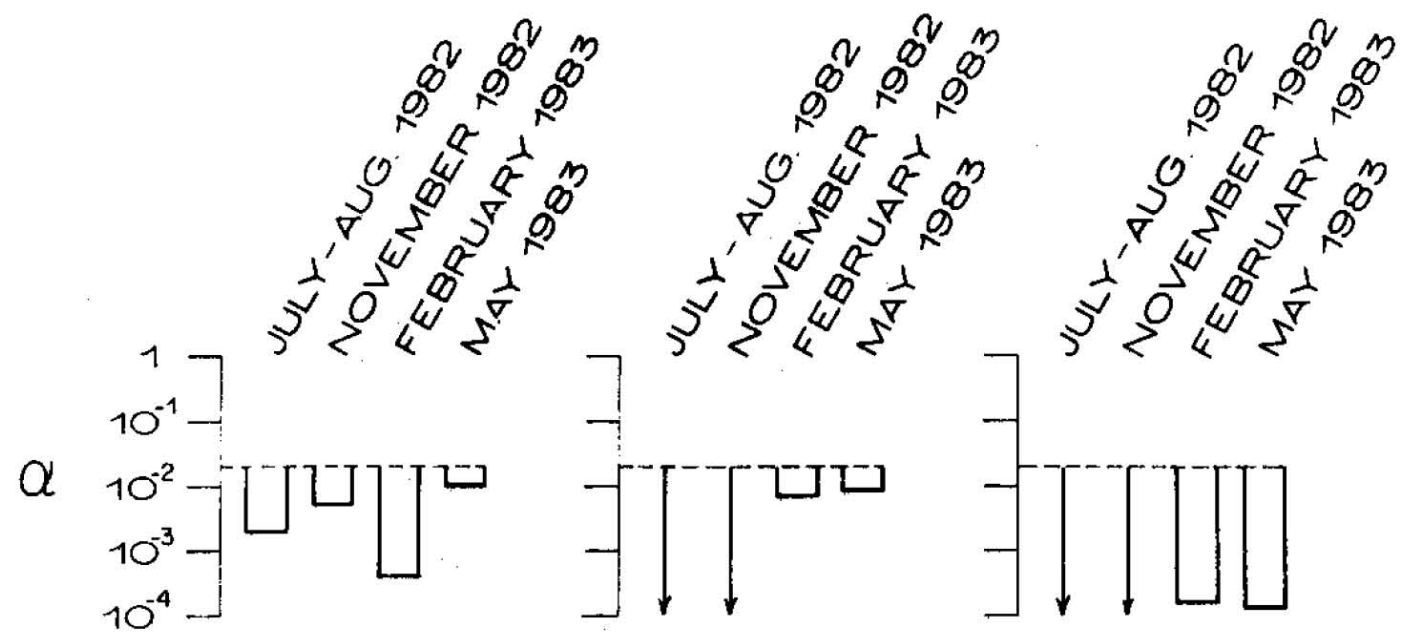

Ampelisca agassizi Ericthonius fasciatus Photis pollex

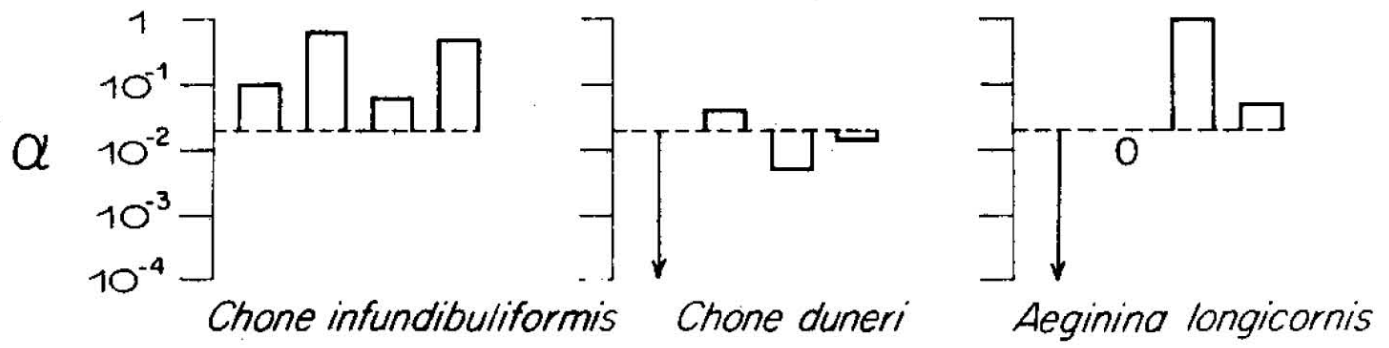

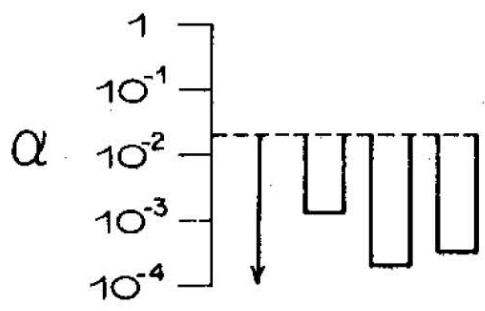

Nephtys incisa

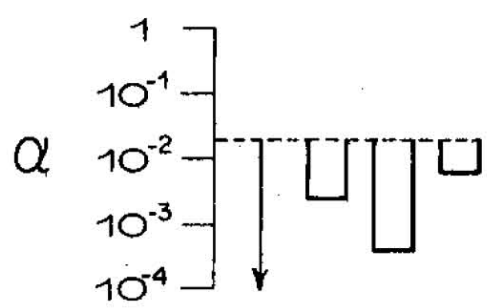

Ninoe nigripes

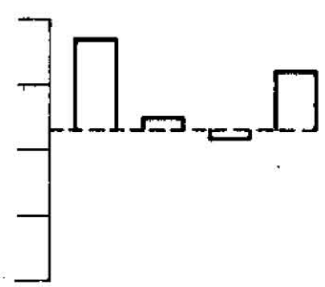

Pherusa cf. folcato
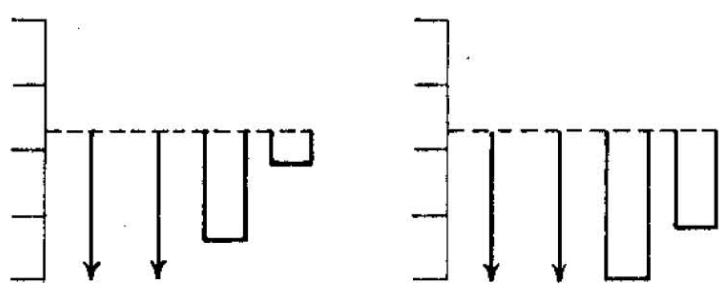

Figure 2-14. Yellowtail flounder selectivity for benthic prey at Station 13. The dashed line in each subplot is the value for neutral selection. Arrows indicate that the prey species was present in benthic grab samples but not eaten by flounder on that date; $\alpha$ is zero in this case. Zeros below the dashed line indicate that the prey species was not found in benthic grab samples on that date; in this case $\alpha$ is undefined. 
causality from the Index alone.

Of the three stations, seasonal $\alpha$ values were most consistent at Station 5, owing to the high degree of overlap between the contents of the fish stomachs and grab samples there. The $\alpha$ values were most variable at Station 10 , due to the predominance of pelagic and rare benthic specles in the flounder diet. In July, the high $\alpha$ for Pagurus, which was rare but present in the grab samples, resulted in low values for the remaining species. In May a similarly high a for Pontogenela Inermis (a mainly pelagic amphipod, not shown) diminished $\alpha$ for the remaining species. Seasonal $\alpha$ values were more consistent at Station 13 except in February when Aeginina longicornis dominated the diet but remained rare in the grab samples. The high $\alpha$ value for $\underline{A}$. longicornis depressed $\alpha$ for the remaining species.

The yellowtail flounder diet is plastic in that the dominant species vary from station to station. On the other hand selectivity values are consistent for those prey spectes when eaten at two or more stations. For example, A. 1ongicornis was positively selected at all three stations. Ericthonius fasciatus was almost neutrally selected at Station 5 and slightly negatively selected at Station 13. Chone infundibuliformis was positively selected at Stations 5 and 13 ; $\underline{\text { c. duneri was }}$ neutral to slightly negatively selected at the same stations. Finally, Lumbrineris fragilis was neutrally selected at Station 10 and slightly positively selected at Station 5 .

My second step in calculating selectivity indices was to use the size-frequency distributions of important prey species to partition the prey numbers into size classes. I created new flsh-stomach and grab-sample data files, each file consisting of an array of species, some of which are partitioned by size class. Using these new data flles, I 
Table 2-2. Relationships between length (L) in $\mathrm{mm}$ and wet weight (W) in mg for five species as fitted by linear regression to the equation $\log (W)=a+b \log (L)$. All weights are from live animals except for $C$. Infundibuliformis in which case only preserved worms were avallable.

\begin{tabular}{lcccc}
\hline \multicolumn{1}{c}{ Species } & n & a & b & r \\
\hline Ampelisca agassizi & 87 & 0.020 & 2.70 & 0.97 \\
Unciola Inermis & 39 & 0.050 & 2.48 & 0.97 \\
\hline Ericthonfus fasclatus & 86 & 0.025 & 2.48 & 0.98 \\
Chone Infundibuliformis & 48 & 0.019 & 2.59 & 0.87 \\
Echinarachn1us parma & 66 & 0.839 & 2.38 & 0.97 \\
\hline
\end{tabular}


calculated $\alpha_{1 j}$ values by Eq. 2-15. For the purpose of calculating $1 / \mathrm{n}$ (the value corresponding to neutral selection), $n$ is now the total number of prey categories. I converted the length classes, as shown in Figs. 2-6 to $2-10$, to welght classes using the length-weight regressions listed in Table 2-2.

In Fig. 2-15, I plotted $\alpha_{1 j}$ values of five prey species against prey weight on $\log -\log$ axes. This plot is a composite, not only of prey specles, but also of different stations. The Ericthonius fasciatus and Unciola inermis data are from Station 5, the Echinarachnius parma data, Station 10 and the Ampelisca agassizi and Chone infundibuliformis data, Station 13. Since selectivity values are consistent among stations, as explained above, this among-station comparison of $\alpha_{i j}$ should be valid. For most prey size classes, I could calculate $\alpha_{i j}$ values for all four seasons; Fig. 2-15 shows the mean and range (vertical lines) of $\alpha_{i j}$ values for each spectes. Again, the dashed line indicates the $\alpha_{i j}$ value corresponding to neutral selection.

Fig. 2-15 compares selectivity among different size classes of different species. Together, the five prey species describe a composite, dome-shaped, size-selection curve. Size selection for the three amphipod species (open symbols) was strongly negative for the smallest (juvenile) size classes and increased with prey size. All sizes of the polychaete, Chone infundibuliformis, were positively, and more or less equally selected. I calculated $\alpha_{i j}$ values for the Levinsenia gracilis size classes shown in Fig. 2-11, but, lacking a conversion from setiger number to wet weight, I could not plot this species' $\alpha_{i j}$ values in Fig. 2-15. All size classes of $L$. gracilis were negatively selected, as would be expected for such a small worm (mean weight $0.3 \mathrm{mg}$ ). 


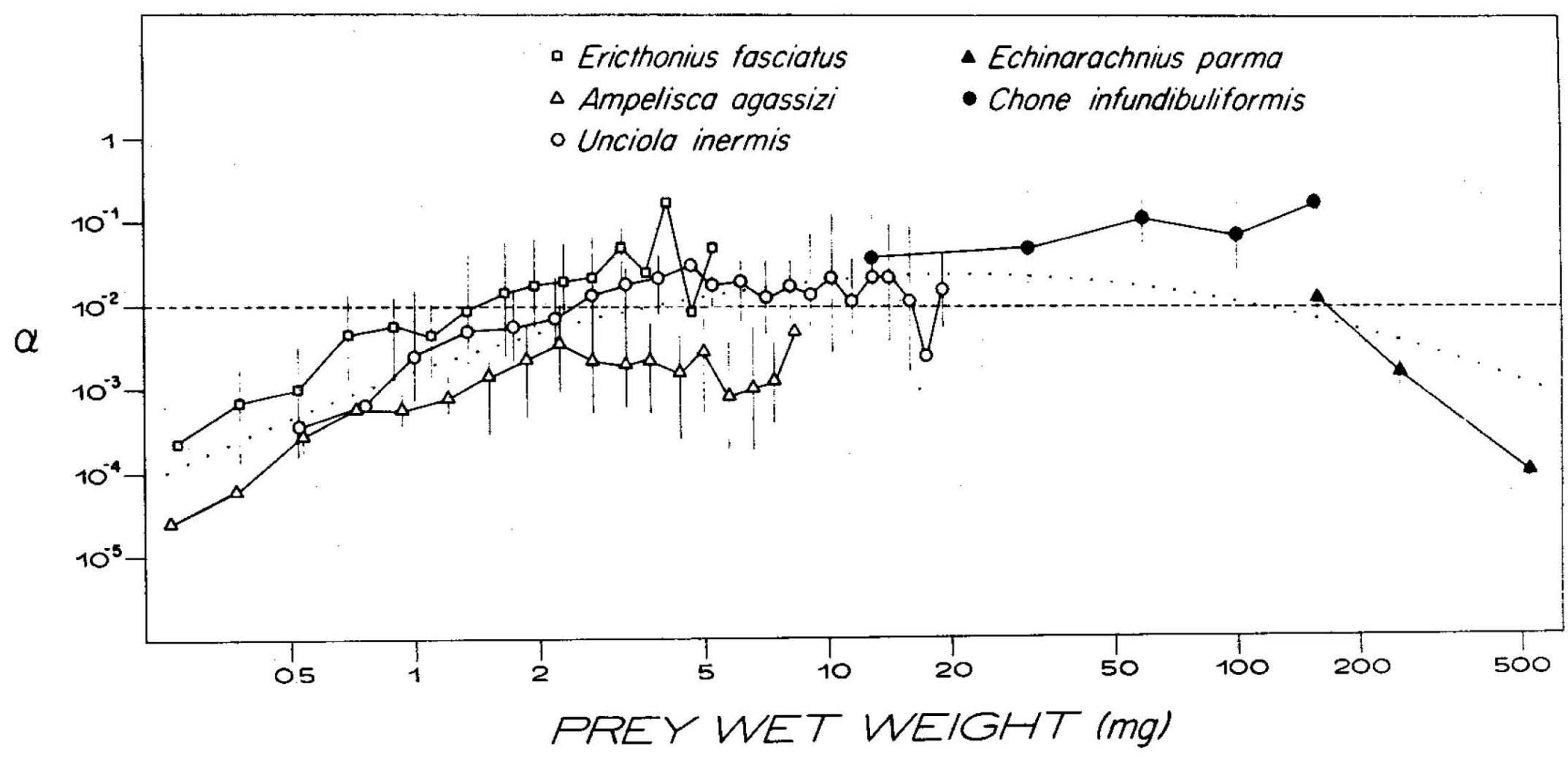

Figure 2-15. Yellowtail flounder size selectivity for five benthic prey species. The symbols indicate the means of four seasonal values and the vertical lines indicate the ranges between minimum and maximum $\alpha_{i j}$ values. The dashed line is the value for neutral selection. The dotted curve is the least-squares fit to Eq. 2-10. 
Only three of the Echinarachnius parma size classes plotted in F1g. 2-9 appeared both in the fish stomachs and grab samples; selectivity for all three decreased with prey size. Juvenile sand dollars, weighing approximate1y $0.5 \mathrm{mg}$ each, were numerous in the grab samples but never eaten by flounder. Intermediate-sized sand dollars, weighing about $40 \mathrm{mg}$ each, were eaten but did not appear in the grab samples. Sand dollars larger than $500 \mathrm{mg}$ each, although abundant at Station 10, were not eaten by flounder. E. parma, by itself, probably describes a dome-shaped size-selection curve but unfortunately, only three of these sizes can be plotted in Fig. 2-15.

In summary, these five prey species define the upper and lower size limits of food acceptable to yellowtall flounder. Prey items between about 2 and $200 \mathrm{mg}$ are positively selected by flounder. In fitting Eq. 2-10 to the observed $\alpha_{1 j}$ values, I ignored the species coefficient $\left(\rho_{1}\right)$ because the five prey species define a composite size-selection curve. The least-squares $\left(\mathrm{r}^{2}=0.53\right)$ fit to Eq. 2.10 is indicated by the dotted curve in Fig. 2-15 (a lognormal curve is parabolic when plotted on $\log -\log$ axes). According to this fit, the optimal prey welght is $21.0 \mathrm{mg}$ and the variance $\left(\sigma^{2}\right)$ of the lognormal size-selection function is 0.34 $\log$ (mg). 


\section{DISCUSSION}

Results of the fish stomach-contents analysis agree with published reports of yellowtail flounder food habits (Langton 1983, Bowman and Michaels 1984) In that arthropods and polychaetes were the major prey groups. Many of the Important prey specles were the same in my study as those found previously; these include polychaetes (Lumbrineris spp. and Nephtys spp.), amphipods (Unciola spp.), and decapods (Crangon septemspinosa). The two studies cited above were based on the stomach contents of flounder collected over wide geographical areas; not surprisingly, the stomach contents reflected the diversity of benthic communities on which the fish fed. In my study, f1sh were caught in relatively small areas in which each benthic communities is relatively uniform. Although the flounder diet varled among stations, at each station a few prey species dominated the diet.

Yellowtall flounder feed mainly during the daylight hours (Langton 1983 and Fig. 3-1), from which we infer they are visual predators. The main prey of yellowtail flounder are animals living on or near the sediment surface. The selectivity indices in Figures 2-12 to 2-14 can be interpreted in relation to where the prey species live, how they feed and what size they are. Prey sizes, given in parentheses in the following paragraphs, are mean welghts from all flsh stomachs at each station and were calculated by dividing the total weight of each species by the number of individuals. Although biased by partial digestion, these weights provide relative sizes for those species not individually measured.

Compared to the electivity indices presented in Collie and Curran (1985, Figs. 104 to 106), fewer specles are positively selected according 
to the $\alpha$ index. This is because $\alpha$ compares selectivity only among those species occurring both in the diet and in the benthos (set $\mathrm{C}$ ), while Ivlev's E applles to all species (FSUGS). As a result, E values tend to the positive and negative extremes, while $\alpha$ values tend to neutral selection.

The numerically dominant prey species at Station 5, Ericthonius $\underline{\text { fasciatus }}$ and Unciola inermis, are both tubicolous amphipods and were approximately neutrally selected (F1g. 2-12). U. irrorata, a1though much less abundant than $\underline{\mathrm{U}}$. $\underline{\text { inermis }}$ in the benthos, was more strongly selected for by flounder. U. Irrorata usually inhabits tubes constructed by other amphipods or polychaetes, but can bulld a tube of its own if no others are avallable (Bousfield 1973). Smith (1950) observed these amphipods swimming or roaming across the bottom, leaving their tubes for considerable lengths of time. U. Irrorata $(4.5 \mathrm{mg})$ is more strongly selected than $\underline{U}$. Inermis $(3.3 \mathrm{mg}$ ) perhaps because it is more epifaunal in habit or because it is larger.

The caprellid, Aeginina longicorn1s $(3.2 \mathrm{mg}$ ), has been collected from sea grass, macroalgae, hydro1ds and bryozoans (McCain 1968); this eplbenthic habit explains its positive selectivity by flounder. The amphipod Stenopleustes Inermis is also thought to live on hydroids because other species in its genus have been collected from hydroids (Lincoln 1979) and alcyonarians (Sars 1895). S. inermis is not as strongly selected for by flounder as are the other amphipod species, perhaps because of 1 ts smaller size $(1.7 \mathrm{mg})$. The brittle star, Amphlpholis squamata ( $2.7 \mathrm{mg}$ ), burrows superficlally in sandy substrata (Gosner 1971) and may therefore avold predation.

The sabellid polychaetes, Chone Infundibuliformis and $\underline{C}$. duneri feed with tentacles above the surface (Fauchauld and Jumars 1979), exposing 


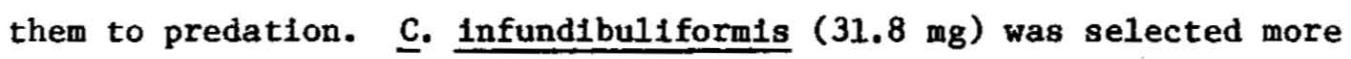
stongly than the smaller species, $\underline{c}$. duneri $(6.5 \mathrm{mg})$. Most lumbrinerid polychaetes are burrowers (Fauchald and Jumars 1979), which makes them less vulnerable to predation by flounders. Lumbrineris fragilis was positively selected by flounder probably because of 1ts large size (851.0 $\mathrm{mg}$ ). Most members of the family Maldanidae are tubicolous (Fauchald and Jumars 1979). Of the two maldanids included in Fig. 2-12, the larger, Clymenura polaris $(19.5 \mathrm{mg})$, was selected for and the smaller, Euclymene sp. A ( $3.3 \mathrm{mg})$, was selected against. All nephtyids are free-living burrowers (Fauchald and Jumars 1979); this probably explains why Aglaophamus c1rcinata was negatively selected despite 1ts large size $(51.4 \mathrm{mg})$.

At Station 10 (Fig. 2-13) there was less overlap between diet and benthos. Many of the important prey species were pelagic or otherwise rare in the grab samples. The two most abundant amphipod species there, Rhepoxynius hudson1 and Protohaustorius w1gley1, are both burrowers and both were selected against by flounder. The sand dollar, Echinarachnius parma, although it lives on the surface, was negatively selected. The large burrowing worms, Lumbrineris fragilis (180.6 mg) and Nephtys bucera $(295.0 \mathrm{mg})$, were more or less neutrally selected, as were Sthenela1s Iimicola $(45.5 \mathrm{mg})$ and C1rolana polita $(41.0 \mathrm{mg})$.

Station 13 (Fig. 2-14) had the greatest overlap between f1sh diet and macrobenthos. Ampelisca agassiz1, the dominant amphipod species there, builds its tubes verticaly into the substratum and may thus avoid predation. Another amphipod species, Photis pollex, was strongly selected against, probably because of 1 ts small size $(0.3 \mathrm{mg})$. The flabellegerld polychaetes, Pherusa cf. falcata (108.9 mg) and Brada villosa ( $51.2 \mathrm{mg}$ ), are surface-dwelling deposit-feeders (Fauchald and 
Jumars 1979); together with their large size, this probably explains their positive selection by flounder. The remaining polychaete species are all sub-surface burrowers and were all negatively selected.

Figures 2-6 to and 2-8 showed that predation on amphipods was size dependent. Selectivity indices calculated for each amphipod size class (F1g. 2-15) indicate that size selection was consistent among seasons and among prey species. In general, selectivity was strongly negative for juveniles, increased with prey size, and was more or less constant for adult (larger than $2 \mathrm{mg}$ ) amphipods. Several authors have noted that mature amphipods spend more time than do juveniles swimming in the water colum (see Chapter One). This could partly explain the higher selectivity values for the larger amphipods, as all three species mature at about $2 \mathrm{mg}$.

Even when selectivity is standardized for the effect of size, differences are apparent among the amphipod species. In other words, at a given prey weight, Ericthonius faciatus is most highly selected and Ampelisca agassizi the least selected. As I discussed in the Chapter One, this observation can be explained by the species' different life-history strategies. E. faclatus, the most eplfaunal in habit, is most vulnerable to predation; Unciola Inermis is intermediate in these traits; A. agassizi, the most sedentary, avoids predation by building its tubes into the substratum.

Yellowtall flounder predation on Echinarachnius parma (F1g. 2-9) was strongly size selective. Sand dollars 6 to $12 \mathrm{~mm}$ long were selected for while juveniles and individuals larger than $12 \mathrm{~mm}$ were selected against. Presumably, no 2 to $6 \mathrm{~mm}$ sand dollars were available in the benthos. Due to the relatively small mouth gape of yellowtail flounder, it probably cannot feed on sand dollars larger than $16 \mathrm{~mm}$, tentatively explaining the 
negative selectivity values obtained for E. parma In Fig. 2-13. Flounder selected sand dollars within a narrow size range, and most of the sand dollars at Station 10 were elther too big or too small. Predation by yellowta1l flounder and other fish on the intermedtate sizes of $\underline{E}$. parma spectes could explain the absence of such sand dollars in benthic grab samples and why juvenile E. parma did not appear to survive and grow.

There was a very close correspondance between avallable and ingested prey sizes of Chone Infundibuliformis (Fig. 2-10). Fig. 2-15 shows that all size classes were positively selected by flounder, suggesting that C. infundibuliformis is the optimum prey size. Yellowtall flounder appeared to select the smaller sizes of Levinsenia gracilis (Fig. 2-11). This is surprising because $\underline{L}$. gractils is a very small worm species -smaller than flounder generally choose. Rather than being selected by flounder, it seems probable that $\underline{L}$ gracilis was eaten incidentally since it is very numerous at Station 13.

To meaningfully compare size selection among prey species, a common unit of measurement is necessary. If flounder are gape limited, prey width determines what will fit through the mouth. Wet weight is important because it determines the amount of prey blomass eaten; ash-free dry weight is important because it determines the actual food value obtained. By converting prey sizes to wet weights I obtained the continuous size-selection curve given in Fig. 2-15; it suggests that biomass may be an important criterion of size selection.

Selection against juvenile amphipods and sand dollars and against the small worm, Levinsenla grac1lis, Indicates that there is a minimum suitable prey size. Two factors could define this minimum size threshold. A sensory limit may exist if flounder cannot detect prey below a certain size. Or, foraging for such small prey may be energetically 
Inefficient. Since sand dollars are hard and approximately round, the width of a sand dollar must be able to pass through the flounder mouth. Therefore the largest sand dollar eaten $(16 \mathrm{~mm})$ is probably a good measure of the maximum gape size.

The overall mean weight of yellowtall flounder caught in this study was $312 \mathrm{~g}$ (weighted mean calculated from Appendix B) and the optimal prey size was $21 \mathrm{mg}$. Thus, the predator (W) to prey (w) weight ratio is about $15,000: 1$ and the $\operatorname{logarithm}, \log (W / w)$, 1s 4.2. This ratio is equivalent to $\eta$ in Eq. 2.9 and is consistent with other authors' findings. Hahm and Langton (1984) calculated a mean $\log (\mathrm{W} / \mathrm{w})$ value of 4.2 for both yellowtall flounder and witch flounder. Arntz and Ursin (1981) calculated an array of $\eta$ values for various size classes of dab (Limanda limanda) feeding on nine prey species; the mean $n$ value was 3.6 .

Andersen (1982) proposed that size selection is a lognormal function of prey size (Eq. 2-9). According to this arguement, a prey item twice as large as the optimum size should be selected equally to a prey item one half the optimum size. This lognormal function has been successfully fit for whiting eating fish (Ursin and Arntz 1985a) and for dab feeding on f1sh (Ursin and Arntz 1985b). Hahm and Langton (1984) plotted frequency distributions of $\log (\mathrm{W} / \mathrm{w})$ for cod, silver hake and yellowtail flounder. Although these frequency distributions are jagged and skewed, it is easy to imagine them fit by normal curves.

In contrast, Zaret (1980) argued that gape-1imited predators should prefer the maximum prey size they can swallow, such that the pattern of selectivity should abruptly truncate at the maximum prey size set by morphology. Schmitt and Holbrook (1984b), testing this hypothesis, found that black surfperch and striped surfperch were not gape limited and that size-selection curves were roughly bell shaped. My composite, slze- 
selection curve (F1g. 2-15) was f1t reasonably well by a lognormal curve. Alpha falls off abruptly for large Echinarachnius parma, suggesting a truncated distribution, but the $\alpha$ values have too much scatter to draw a firm conclusion. The upper size limit, imposed by gape limitation, is certainly more rigid than the lower, more flexible size limit imposed by foraging constraints.

I return finally to the question of whether predation patterns are predictable if the abundance, 1ife history and size distributions of prey species are known. Most of the among-species differences in selectivity (Figs. 2-12 to 2-14) can be explained by prey life history and size. Size selection also may account for some of the among-season variability in selectivity. For example, selectivity for Unciola inermis (Fig. 2-12) was lower in the spring and summer when juveniles were abundant (Fig. 1-4) and higher in fall and winter when only the adult sizes, which are preferred by flounder, were present. Similarly, selectivity for Echinarachnius parma (Fig. 2-13) was lowest when the number of juveniles was highest (Collie and Curran 1985, Fig. 98). This explanation of among-season variability, however appealing, is not supported by the other two amphipod species I studied in detail.

Fig. 2-15 showed that size-selection is important but that amongspecies differences persist even when the data are standardized for size. There was considerable among-season variation in size selectivity for each species. This variation was not random, but rather, all values for a season were higher or lower than the mean. Some of this residual variation, not accounted for by the size-selection index, is due to the fact that the benthic grab did not adequately sample all the species in the fish diet (sets $P$ and $R$ ). This was especially true at Station 10 where high $\alpha$ values for Pagurus spp. and Pontogeneia inerm1s depressed 
the $\alpha$ values for the remalning spectes. Aeginina longicornis had a similar effect at Station 13 in February when it dominated the diet. A. longicornis, residing on hydroids, is very patchily distributed and therefore 1 ts abundance is not measured well by a small grab sample. An alternative explanation is that flounder feeding behavior switches in relation to prey abundance. Selectivity indices assume that prey species are eaten in proportion to their abundance in the environment. However, switching behavior has been observed in several fish species (Murdoch et al. 1975, Love and Ebeling 1978) and it is evident1y induced by threshold prey densities (Pyke 1979). My fleld study was not designed to detect this more complex behavior; a controlled, manfpulative experiment would be required to test this hy pothesis. 
CHAPTER THREE

RATE OF FOOD CONSUMPTION BY YELLOWTAIL FLOUNDER

\author{
INTRODUCT ION
}

In this chapter I estimate the rate of food consumption by yellowtail flounder. Chapter Two dealt with the composition of the flounder diet; Chapter Three is on the quantity of food eaten. My main reason for estimating consumption 18 to be able to compare the rates of food consumption by flounder to production rates of 1mportant prey spectes. From this comparison, one can infer the effect of flounder predation on benthic prey populations. Chapter Three is a synthesis of results presented in Chapters One and Two, new stomach-content data and information from other studies.

To estimate food consumption by fish in the sea, one must know the consumption rate per fish and the density of fish in the sea; each of these is a non-trivial problem in 1tself. By maintaining fish in aquaria, one can be measure consumption rate directly, but such data may bear little relation to natural feeding rates. Food consumption in the sea must be estimated indirectly, by bioenergetic calculations or from stomach contents. Both approaches have been used to estimate food consumption rates for several important Northwest Atlantic fish species. According to the bioenergetic approach, consumption is the amount of food a fish requires to satisfy its total metabolic requirements. Grosslein et al. (1980) used this method to estimate annual consumption by six fish species on Georges Bank. Consumption (C), in units of weight, was calculated as: 


$$
C=(G+S+Q) / a,
$$

where growth (G), reproduction (S) and respiration (Q) are all functions of weight. The assimilation coefficient (a) was assumed to be 0.8 . The consumption to biomass ratio $(\mathrm{C} / \mathrm{B})$ of yellowtail flounder ranged from 6.5 for age $1 \mathrm{fish}$ to 3.0 for age $10 \mathrm{flsh}$ the mean $\mathrm{C} / \mathrm{B}$ over all ages was 4.6 (Grosslein et al. 1980, Tables 16 and 21).

The stomach-content method of estimating consumption rate is based on the amount of food in the stomach and 1 ts rate of elimination. Durbin et al. (1983), in reviewing evacuation rate studies, concluded that an exponential model of gastric evacuation provides a good fit to most experimental data. If one assumes that the rate of food intake (F) is constant over some sampling interval and that the hourly rate of gastric evacuation ( $r$ ) is proportional to the weight of food in the stomach (S), the rate of change in stomach contents can be expressed by the differential equation,

$$
\mathrm{dS} / \mathrm{d} t=\mathrm{F}-\mathrm{rS}
$$

(E1liott and Persson 1978). The solution obtained by integrating Eq. 3.2 is,

$$
S_{t}=S_{0} \exp (-r t)+F(1-\exp (-r t) / r
$$

Given the above assumptions, $F$ is the consumption (C) during the interval 0 to $t$. Rearranging,

$$
c=r t\left(S_{t}-S_{0} \exp (-r t)\right) /(1-\exp (-r t))
$$


Eq. 3.4 is useful for estimating consumption from stomachs contents of fish sampled perlodically over a time-span of at least 24 hours. These consumption estimates may be biased if the feeding rate is not constant during the sampling interval; Eggers (1977) recommended an interval not longer than three hours.

Eggers (1979) pointed out that a correct solution to Eq. 3.2 is also:

$$
r t \bar{s}=c-\left(s_{t}-s_{0}\right)
$$

where $\bar{S}$ is the mean stomach-content weight from time 0 to $t$. For fish with daily feeding patterns, stomach-contents weight should be nearly equal at a given time on successive days. Dally consumption $\left(C_{24}\right)$ is then:

$$
C_{24}=24 r \bar{S}
$$

Pennington (1981) showed that Eq. 3.5 is an unblased estimator provided the samples are collected randomly over time. Furthermore, if $t$ is large, the difference, $\mathrm{s}_{t}-\mathrm{S}_{0}$, In Eq. 3.5 is Insignificant. Therefore, Eq. 3.6 holds for large $t$ even if feeding is apertodic.

It is evident from Eq. 3.6 that the food consumption estimate depends directly on the gastric evacuation rate $(r)$. This rate, $r$, has been determined for several species of marine fish but not for yellowtail flounder. Gastric evacuation rates are affected by temperature, food type, food particle size, meal size and feeding regime (Fange and Grove 1979); of these factors, temperature and food type are the most important. Durbin et al. (1983, Appendix 1) plotted gastric evacuation 
rates ( $r$ ), of marine and freshwater fish, as a function of temperature. The slopes of the relation between $\log (r)$ and temperature (T) were similar for different fish species, but the intercept depended on prey type. For several species of marine fish (cod, flounder, menhaden) fed small prey (1ess than $0.5 \mathrm{mg}$ ), the relationship between $r\left(\mathrm{hr}^{-1}\right.$ ) and $\mathrm{T}$ $\left({ }^{\circ} \mathrm{C}\right)$ was:

$$
r=0.0406 \exp (0.111 \mathrm{~T})
$$

Estimates of fish population abundance are required not only for ecological studies, such as this one, but as a basis for fisheries management. Herein is a short review of the large literature on enumerating fish populations, as it pertains to yellowtail flounder abundance on Georges Bank. There are several different methods of enumerating fish, each with strengths and weaknesses. The choice of method depends on the type of fish, its habitat and the eventual use for the data. For many management purposes, overall population size is the most important result; for ecological studies, such as this one, fish abundance per unit area is needed.

Uzman et a1. (1977) compared three direct methods for estimating the abundance of megafauna on Georges Bank: manned submersible, towed camera sled and standardized otter trawl. In all three methods, faunal density was calculated by dividing the number of animals in each taxonomic group by the area covered. The submersible and camera sled were more effective than the trawl in enumerating benthic specles; the otter trawl ylelded the highest estimates for pelagic fish and squid. The main drawbacks to submersible and camera surveys are that it is possible to cover only relatively small areas, and that it is often not possible to identify 
animals to the species level. The otter trawl provides specimens for direct examination, but is a relatively inefficient sampler.

Indirect methods of estimating fish abundance include catch-data analysis, tag-recapture studies and acoustic surveys. Time series of fisheries catch data can be used in several different ways (Cushing 1981, Chapter 5) to reconstruct fish population dynamics and thus to estimate population size. By definition, these methods apply only to exploited populations and perform better as the level of exploitation increases. The drawback to using such methods for estimating fish density per unit area is that the population estimates usually apply to a broad geographic region. One must assume that the fish population is uniformly distributed in a specific area and that there is no mixing between populations.

Collie and S1ssenwine (1983) developed a method of estimating population size based on commercial catch data and standardized, otter-trawl, survey data. In essence, this method uses commercial catch data to standardize the survey's relative abundance data. The method also accounts for the error inherent in measuring relative abundance. We estimated the abundance of yellowtail flounder on Georges Bank and in Southern New England as examples of how the method works.

Consumption rate per fish has been calculated for several North Atlantic fish species; these studies are summarized in Table 3-1. When the consumption rates are expressed as percent body weight per day, it is evident that smaller fish eat proportionately more than larger fish of the same species. The consumption rates vary from $0.8 \%$ for $60-\mathrm{cm}^{-1}$ ong cod to $3.2 \%$ for silver hake less than $20 \mathrm{~cm}$ long. The results agree remarkably well, despite the different methods used by different authors.

Grosslein et al. (1980) calculated consumption per unit area by multiplying their $\mathrm{C} / \mathrm{B}$ by the flsh population biomass (as estimated from 
Table 3-1. Consumption rates of seven North Atlantic fish species.

\begin{tabular}{|c|c|c|c|c|c|}
\hline Spectes & Length $(\mathrm{cm})$ & Location & Method & $\begin{array}{l}\text { nsumption Rate } \\
\text { body wt. day-1 }\end{array}$ & Reference \\
\hline Herring & all & Georges Bank & bioenergetics & 1.26 & Grosslein et al. (1980) \\
\hline Mackerel & all & Georges Bank & bioenergetics & 1.18 & Grosslein et al. (1980) \\
\hline Silver hake & $\begin{array}{l}\mathrm{all} \\
<20 \mathrm{~cm} \\
>20 \mathrm{~cm}\end{array}$ & $\begin{array}{l}\text { Georges Bank } \\
\text { Northwest Atlantic }\end{array}$ & $\begin{array}{l}\text { bioenergetics } \\
\text { stomach contents }\end{array}$ & $\begin{array}{l}1.34 \\
2.9-3.2 \\
0.8-2.2\end{array}$ & $\begin{array}{l}\text { Grosslein et al. (1980) } \\
\text { Durbin et al. }{ }^{(1983)}\end{array}$ \\
\hline $\operatorname{cod}$ & $\begin{array}{l}40 \mathrm{~cm} \\
60 \mathrm{~cm} \\
40 \mathrm{~cm} \\
" " ~ \\
60 \mathrm{~cm} \\
" " ~ " \\
\text { a11 } \\
>30 \mathrm{~cm}\end{array}$ & $\begin{array}{l}\text { North Sea } \\
" " \\
" \\
" \\
" \\
" \\
\text { Georges Bank } \\
\text { Northwest Atlantic }\end{array}$ & $\begin{array}{l}\text { stomach contents } \\
\text { " } \\
\text { bioenergetics } \\
\text { stomach contents } \\
\text { bioenergetics } \\
\text { stomach contents } \\
\text { bioenergetics } \\
\text { stomach contents }\end{array}$ & $\begin{array}{c}1.3 \\
0.8 \\
1.14 \\
1.3-1.7 \\
0.8-1.2 \\
1.4-1.9 \\
0.9 \\
0.9-1.5\end{array}$ & $\begin{array}{l}\text { Daan }(1973) \\
" \\
\text { Jones }(1978) \\
" \\
" \\
" \\
\text { Grosslein et al. (1980) } \\
\text { Durbin et al. (1982) }\end{array}$ \\
\hline Haddock & $\begin{array}{ll}50 & \mathrm{~cm} \\
" * \\
\mathrm{a} 11\end{array}$ & $\begin{array}{l}\text { North Sea } \\
\text { " } \\
\text { Georges Bank }\end{array}$ & $\begin{array}{l}\text { bloenergetics } \\
\text { stomach contents } \\
\text { bioenergetics }\end{array}$ & $\begin{array}{l}1.51 \\
1.19 \\
0.88\end{array}$ & $\begin{array}{l}\text { Jones }(1978) \\
" \text { " } \\
\text { Grosslein et al. (1980) }\end{array}$ \\
\hline $\begin{array}{l}\text { Yellowta1l } \\
\text { flounder }\end{array}$ & all & $\underset{" \text { Georges Bank }}{\|}$ & $\begin{array}{l}\text { bioenergetics } \\
\text { s tomach contents }\end{array}$ & $\begin{array}{c}1.26 \\
0.2-1.7\end{array}$ & $\begin{array}{l}\text { Grosslein et al. (1980) } \\
\text { This study }\end{array}$ \\
\hline $\begin{array}{l}\text { Winter } \\
\text { flounder }\end{array}$ & $\begin{array}{l}? \\
10-40 \mathrm{~cm} \\
50.5 \mathrm{~cm}\end{array}$ & $\begin{array}{l}\text { Laboratory } \\
\text { " } \\
\text { Georges Bank }\end{array}$ & $\begin{array}{l}\text { direct observation } \\
? \\
?\end{array}$ & $\begin{array}{l}2 \\
1.8-2.4 \\
1.3-1.5\end{array}$ & $\begin{array}{l}\text { Tyler and Dunn (1976) } \\
\text { Huebner and } \\
\text { Langton (1982) }\end{array}$ \\
\hline
\end{tabular}


catch data) and dividing the area inhabited by the population into the resultant total consumption. I converted their results from kilocalories to grams wet weight, assuming $1 \mathrm{kcal}$ is equivalent to $2 \mathrm{~g}$ (Crisp 1984). Therefore, consumption by yellowta1l flounder was $5.8 \mathrm{~g} \mathrm{~m}^{-2} \mathrm{yr}^{-1}$ from 1964 to 1966 and $4.4 \mathrm{~g} \mathrm{~m}^{-2} \mathrm{yr}^{-1}$ from 1973 to 1975 . Consumption by all fish species on Georges Bank, during the same periods, was 384.1 and $222.7 \mathrm{~g} \mathrm{~m}^{-2}$, respectively.

Peterson (1979) discussed the various methods used to determine whether predators regulate the abundance of benthic macrofauna. One way is to undertake manipulative experiments which usually involve excluding and/or including predators in mesh cages fixed to the sea bottom (e.g. Virnstein 1977). Such experiments, though they demonstrate that predation 11mits macrofaunal abundance, are subject to caging artifacts, especially in areas of high water flow.

A second method of determining the consequences of predation is to directly observe (or calculate from observations) the rate of prey consumption in the field. Pihl (1985), in a synthesis of studies performed on the Swedish west coast in 1977 and 1978, calculated the production and consumption of benthic invertebrates by five predators in two shallow (less than $1 \mathrm{~m}$ ) bays. The predators were juvenile plaice (Pleuronectes platessa), two sand goby specles (Pomatoschistus microps and $\underline{P}$. minutus), brown shrimp (Crangon crangon) and crab (Carcinus maenas). These mobile epibenthic predators are opportunistic carnivores that feed mainly on infauna they select on the basis of relative availability. In one area, Gullmarsik, total food consumption in 1978 was calculated to be $26 \mathrm{~g}^{\mathrm{AFDW} \mathrm{m}} \mathrm{m}^{-2} \mathrm{yr}^{-1}$ (this corresponds to roughly $350 \mathrm{~g}$ wet weight). All epibenthic predators selected the amphipod, Corophlum volutator, during most seasons. The predators consumed $98 \%$, 
$62 \%$ and $92 \%$ of the annual production of $\underline{\text { C. }}$ volutator, $\underline{\text { M. }}$ arenarla and C. edule, respectively.

In a similar study on the Swedish west coast, Evans (1984) reported that Pleuronectes platessa, Pomatoschistus minutus and Crangon crangon consumed 24 to $34 \%$ of total infaunal production. These eplfaunal predators consumed $67 \%, 60$ to $80 \%$, and $4 \%$ of the respective annual production of the important prey species, Corophium volutator, Crangon crangon and polychaete specles, respectively. PhIl's and Evans's studies Indicate that, at least in shallow bays, eplfaunal predators are major biotic regulators of the infaunal community.

A third method of inferring the consequences of predation is to correlate changes in the abundance of predator and prey populations over t1me. Persson (1981) established three lines of evidence suggesting that increased macrobenthic populations in the Baltic Sea resulted from thinning out of the flatfish stocks in the 1930s. Firstly, predator exclusion experiments in 1928 resulted in up to 60-fold increases in the density of preferred prey species. Secondly, surveys carried out following exploitation of the flatfish stocks indicated an increase in biomass of benthic macrofauna. Finally, the flatfish had increased growth rates, which Persson claimed to be a result of reduced competition for food.

Arntz (1980) analyzed eight years of data on the abundance of macrofauna and demersal fish in the Western Baltic Sea. Although fish preyed heavily on benthos, the abundance of one did not appear to depend on the abundance of the other. This does not necessarily mean that the abundances of $\mathrm{f1sh}$ and benthos are unrelated; it could be that they were not sampled closely enough in space and time, or that changes in population size were too small to show effects. 
METHODS

This chapter is based, in part, on the yellowtall flounder stomachcontent data presented in Chapter Two. Therein I described fish stomach collection and analysis; herein I add only those details pertaining to Chapter Three. In this chapter I use the data on stomach content welght (S) and percent composition of the diet by weight.

Fish stomach collection was standardized as much as possible given that the stomachs were collected by different people on a different ship each time. At each station, a No. 35 bottom trawl was towed every three hours, over a 24-hour period, in order to investigate diel feeding behavior. Tow duration ( $30 \mathrm{~min})$ and speed $(3.0$ to 3.5 knots $)$ were kept constant to enable comparison of the catch among stations and seasons. At each station and date, the temperature profile was measured by expendable bathythermograph and calibrated by a surface thermometer reading.

I estimated the consumption rate per fish by two methods: one based on bioenergetics, and the other on stomach contents. For the bioenergetic method, I used the consumption-to-biomass ratio (C/B) calculated for yellowtail flounder by Grossleln et al. (1980, Table 16). To get consumption per flsh, I multiplled C/B by the mean weight of yellowtail flounder collected at Stations 5, 10 and 13 (Appendix B).

There are two alternate forms of the stomach-content method, which are based on the two alternate solutions of Eq. 3-2. The method I call change in stomach-content weight is based on Eq. 3-4. I calculated the mean stomach-content weight $\left(\mathrm{s}_{t}\right)$ for all stomachs, including empty ones, collected in each tow. Using Eq. 3-7 and the corresponding bottom temperature, I calculated the evacuation rate $(r)$. I then applied Eq. 
3-4 to each interval and summed over eight intervals to obtain the daily consumption rate.

In only two cases were enough fish stomachs collected to apply the change-in-stomach-content method; for the remaining stations and dates I relled on the mean-stomach-content method (Eq. 3-6). For each station and date, I calculated the mean stomach-content welght (S) from all stomachs, and the evacuation rate (r) by Eq. 3-7. The variance of consumption was calculated by propagating the variances of the mean stomach-content weights. I then interpolated the consumption rate between sampling dates and multiplied the mean consumption rate for each interval by the interval duration in days. Annual consumption is the sum of consumption during each quarterly sampling interval.

I estimated yellowtail flounder density by two different methods -one direct and one indirect. In the first, I calculated density by dividing the area the otter trawl covered into the number of flounder caught. I estimated the area a standard tow covered by multiplying the ship speed times tow duration times the width of the net opening. Although this method gives a direct measure of abundance, it is an underestimate because the otter trawl does not catch every fish in its path.

Each year, since 1963, the Northeast Fisheries Center (NEFC) has conducted groundfish surveys along the northeast US coast from Cape Hatteras to the Gulf of Maine. These standardized, bottom-traw1 surveys are done with NEFC research vessels in the fall -- and more recently, in the spring and sometimes summer -- of each year. Sampling is based on a stratified random design: the survey area has been stratified into zones based on depth and latitude (see Grosslein 1969, Fig. 2). Stations are allocated to each stratum in proportion to its area, and are located 
within a stratum on a random bas1s. At each station, a standard, " 36 Yankee" trawl is towed for $30 \mathrm{~min}$ at $6.5 \mathrm{~km} \mathrm{hr}^{-1}$.

I applied the Collie and Sissenwine (1983) method of estimating population size to yellowtall flounder groundfish-survey and commercial-catch data published in Clark et al. (1984, Tables 2, 4 and 5). This method estimates the number of fish in the area corresponding to the catch statistics. To get fish density per unit area, I divided population size by the area in which the population lives. I obtained the areas of the approprlate survey strata from Frank P. Almeida, NEFC (personal communication).

To calculate yellowtall flounder consumption per unit area, I multiplied the consumption rate per fish by yellowtall flounder density. The next step was to compare this food-consumption rate to the rates of prey production. In Chapter One, using the increment-summation method (Crisp 1984), I estimated the production of three dominant amphipod species. The species and the stations for which they were analyzed are: Ampelisca agassizi at Station 13 and Unciola inermis and Ericthonius fasclatus, both at Station 5-1 and at Station 5-28. M.C. Curran, also using the increment-summation method, estimated production of the sand dollar, EchInarachnius parma, at Stations 1, 4 and 10 (Collie and Curran 1985).

In this chapter I expand upon my previous production estimates by calculating the production of two polychaete species. As part of their life-history investigation, Blake and Baptiste (1985, Fig. 88) determined the size-frequency of Chone infundibuliformis in five quarterly samples taken at Staltion 13 from July 1982 to July 1983. Because cohorts are not apparent in their size-frequency distributions, it was not possible to estimate production by cohort-based methods. Therefore, I used the 
size-frequency (Hynes) method of estimating production, as modifled by Krueger and Martin (1980).

In the size-frequency method the size distribution of an "average" cohort is obtained by averaging the frequencies in each size class over the year. Production (P) 18 then calculated as the sum of biomass removed between successive size classes, according to:

$$
P=a\left[\quad\left(N_{j}-N_{j+1}\right)\left(w_{j} w_{j+1}\right)^{0.5}\right]
$$

where $N_{j}$ is the mean number in size class $j$ averaged over the sampling dates, $w_{j}$ is the mean weight per individual of size class $j$, and a is the number of size classes.

Krueger and Martin (1980) recommended that the geometric mean weight, $\left(w_{j} w_{j+1}\right)^{0.5}$, be used, because it is more accurate for logarithmic growth patterns. I used the length-weight regression for $\underline{C}$. infundibuliformis (Table 2-2) to convert length to welght. The size-frequency method, though it does not rely on being able to 1dentify cohorts in the size-frequency distributions, does assume that the average life-span is known. It also assumes that the growth rate 18 linear, that all individuals could grow to the maximum size and that the year-to-year population size is the same.

According to Wildish and Peer (1983), Chone Infundibuliformis is an annual species; this is consistent with the length-frequency data in Blake and Baptiste (1985), which suggested that recruitment occurs in spring and early summer. Having estimated production of $\underline{\mathrm{C}}$. infundibuliformis at Station 13, I used the production-to-biomass ratio (P/B) to estimate production of this species at Station 5, from which samples of C. Infundibuliformis were not measured. 
I used the same approach to estimate production of Nephtys Incisa at Station 13. This species was not measured in the GBMP, but N. Incisa production at two other locations on the East Coast has been estimated. For Long Island Sound, Sanders (1956) calculated a production rate of $9.35 \mathrm{~g}$ wet weight $\mathrm{m}^{2} \mathrm{yr}^{-1}$ and a P/B of 2.16. Off the Delaware coast, N. Incisa production was $0.17 \mathrm{~g}$ ash-free dry weight $\mathrm{m}^{2} \mathrm{yr}^{-1}$, and $\mathrm{P} / \mathrm{B}$ was found to be 2.23 (Howe and Leathem 1984). I applied these P/B values to the $\mathrm{N}$. Incisa mean biomass data from Station 13 .

The final step is to calculate yellowtail flounder consumption as a function of prey production. The importance of the various prey species in the flounder diet on a weight basis was shown in F1g. 2-5. I calculated a weighted mean percent of each prey species in the diet by summing the weight of each prey species found in flounder stomachs over four seasons and dividing by the total weight of stomach contents (S). Next, I applied these percentages to the overall food consumption rate, to calculate the consumption rate of individual prey species. Finally I divided the consumption rate for each species by the corresponding prey production rate. 
RESULTS

My first estimates of yellowtail flounder consumption rate were via the bioenergetic method. I used the $C / B$ value of $4.6 \mathrm{yr}^{-1}$ (Grosslein et a1. 1980), which is a geometric mean for all ages during the years 1963 to 1972 . The mean welghts of yellowtall flounder, averaged over the year, caught at Stations 5, 10 and 13 were $348.1,298.1$ and $333.0 \mathrm{~g}$, respectively (Appendix B). Multiplying by $4.6 \mathrm{yr}^{-1}$, I arrived at 1.60 ,

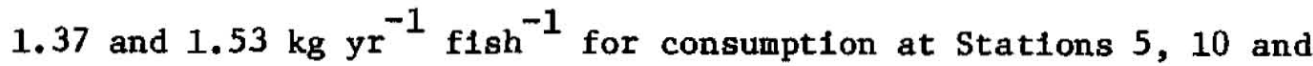
13, respectively.

The second method of estimating consumption is based on the weights of the stomach bolus, which along with bottom temperatures are listed in Table 3-2. These total stomach-content weights differ from those 1isted In Appendix B (which do not include the weights of unidentifiable prey). Typically, the standard deviation of stomach-content weight is as large as the mean. The number of empty stomachs ranged from 8.3 to $65.4 \%$ of the total number examined; thus, some of the variation in stomach-content weight is due to the percentage of empty stomachs. In other words, there is less variability in mean stomach-content weight, among dates and stations, if only those fish with non-empty stomachs are considered.

In on1y two cases (August 1982 and May 1983 at Station 10) were enough stomachs collected to apply the change-1n-stomach-content method. In Fig. 3-1 stomach-content weights $\left(S_{t}\right)$ and $95 \%$ confidence intervals are plotted against the corresponding time of day. The large confidence Intervals are due, in some cases (e.g. 8:40/August and 18:30/May) to small sample sizes ( $n=8$ and 7 , respectively). In general, the variance of stomach-content weight is high because not all fish feed at the same time and there are many empty stomachs at any time of day. 


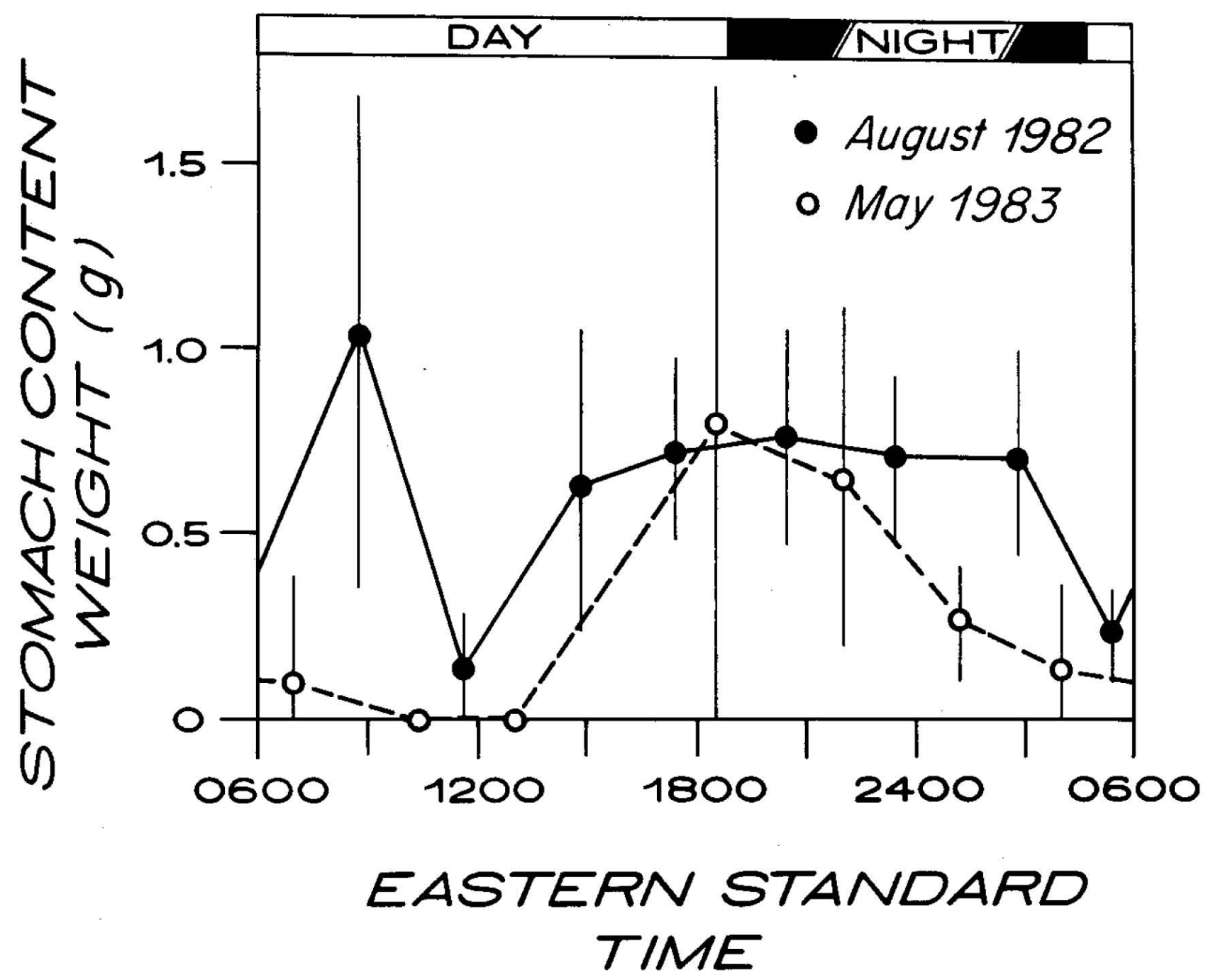

Figure 3-1. Change in yellowtail flounder stomach-content weight over 24 hours. The vertical lines are 95 percent confidence intervals. 
Despite the high varlance, there is a diel trend in stomach-content weight. If one 1gnores the anomalously high value for $8: 40$ /August, stomach-content weight is lowest in the morning (6:00 to 12:00) and highest in the evening (18:00 to 24:00). This diel trend is apparent on both sampling dates. Because the confldence intervals for the two dates overlap at most times, there is no statistical difference between the August 1982 and May 1983 stomach-content weights.

I used Eq. 3-4 to estimate consumption during each time interval. The evacuation rates, as calculated from Eq. 3-7 and the temperatures given in Table 3-2, were $0.142 \mathrm{hr}^{-1}$ and $0.097 \mathrm{hr}^{-1}$ for August 1982 and May 1983, respectively. The ingestion rate was highest from 12:00 to 18:00, then continued at a low level unt11 24:00. The sum of consumption over 24 hours was $2.062 \mathrm{~g} \mathrm{day}^{-1}$ and $0.760 \mathrm{~g} \mathrm{day}^{-1}$ in Aug. 1982 and May 1983 , respectively.

The mean-stomach-content method is applicable to the cases with smaller sample sizes. I estimated dally consumption using Eq. 3-4 and the mean stomach-content weights (S) given in Table 3-2. Evacuation rates $(r)$ were calculated using Eq. 3.7 and the bottom temperatues from Table 3-2. Daily consumption is plotted, in Fig. 3-2, against time of year. I calculated $95 \%$ confidence Intervals by propagating the variance of mean stomach-content weight. The large confidence intervals are due, in some cases, to small sample sizes, the diel feeding cycle (as illustrated in Fig. 3-1), and, more generally, to the variation in feeding behavior among fish. As expected, for August 1982 and May 1983 at Station 10, the consumption rates calculated by the change-instomach-content method are 1dentical to those calculated by the meanstomach-content method.

Annual consumption, obtained by interpolating between sampling dates, 


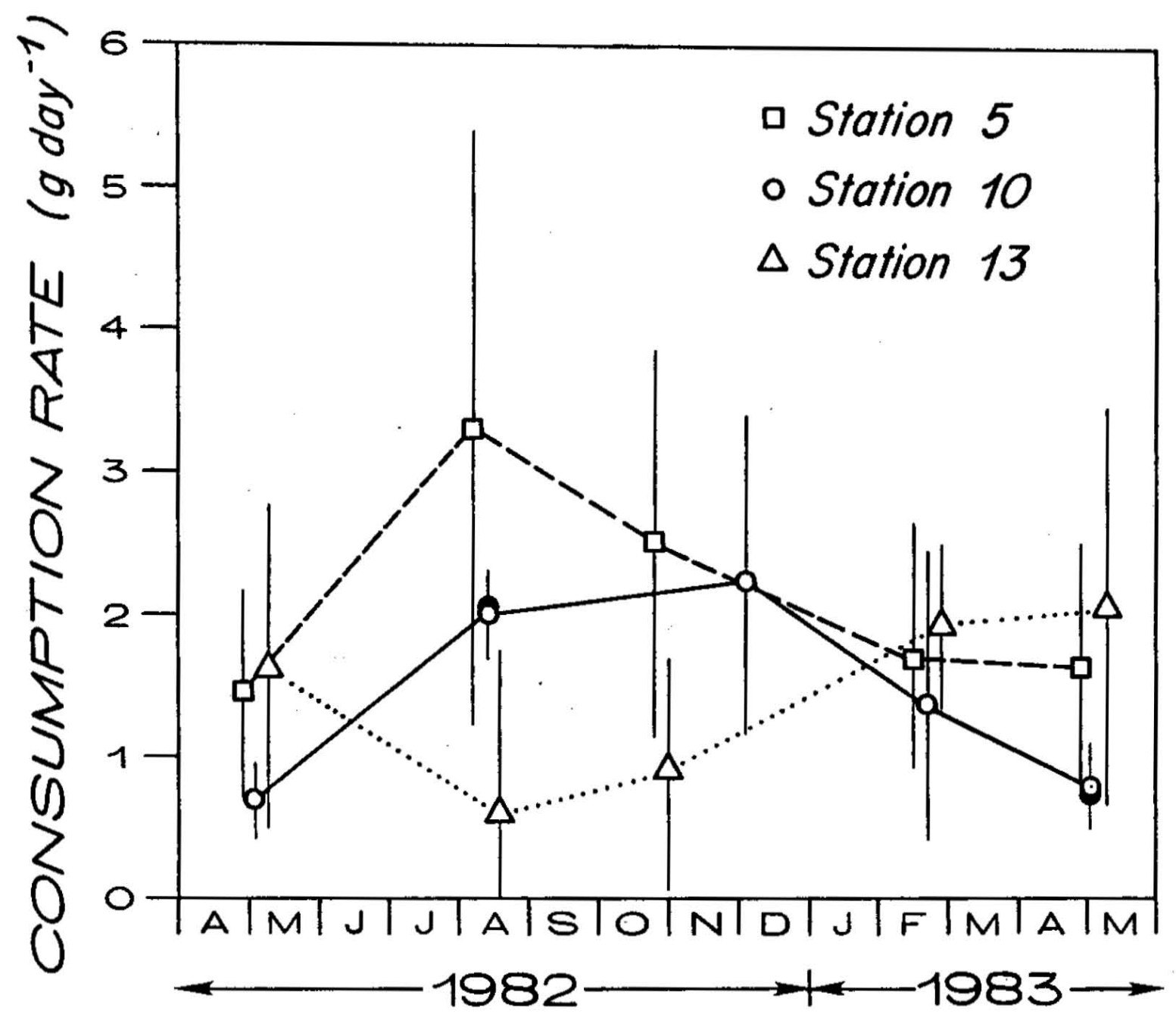

Figure 3-2. Rate of food consumption by yellowtail flounder estimated by the mean-stomach-content method. Units are grams wet weight per day. The vertical lines are 95 percent confidence intervals. The partially eclipsed solid dots represent consumption estimated by the change-in-stomach-content method. (See text for explanation of methods.) 
corresponds to the area under each line in Fig. 3-2. Annual consumption was $0.824,0.605$ and $0.477 \mathrm{~kg} \mathrm{fish}^{-1} \mathrm{yr}^{-1}$ at Stations 5,10 and 13 respectively. Because of the large varlance in dally consumption, these values are probably not statistically different from one another. They are, however, about half or less than half the consumption rates estimated by the bioenergetic method (Table 3-4).

I estimated yellowtail flounder density based on the area trawled and from catch statistics. The standard tow of $30 \mathrm{~min}$. at 3.0 knots covered a distance of $2.78 \mathrm{~km}$. The opening of the otter trawl, when fishing, is about $9.5 \mathrm{~m}$ (Frank P. Almeida, pers. comm.). Therefore, the area covered by a standard tow was $2.64 \times 10^{4} \mathrm{~m}^{2}$. To calculate flounder density I first divided the catch by the area of one standard tow and then by the number of standard tows made at that station and date. The density estimates (Table 3-3) are all quite low; there are no consistent trends among stations or dates. It should be remembered that these are minimum estimates because the trawl does not catch every fish in its path.

I also estimated flounder density based on the area trawled by the NEFC groundfish survey. Benthic Monitoring Stations 5 and 10 are in Survey Stratum 13; Monftoring Station 13 is in Stratum 10. I divided the minimum population estimates for these two strata (Margaret McBride, unpublished data) by the appropriate area, to obain the densities 1isted in Table 3-3. These values are still low but are higher than the densities obtained on the stomach-sampling cruises. In other words, the mean catch-per-tow from the survey strata was generally higher than the catch-per-tow from specific monitoring stations.

As an indirect method of estimating yellowtall flounder density, I applled the Collie and Sissenwine (1983) method to a 21-yr time series (1963-1983) of commercial-catch and research-survey data (Clark et al. 
Table 3-2. Yellowtall flounder stomach-content welghts.

\begin{tabular}{lrrrrrr}
\hline \multicolumn{1}{c}{ Date } & Station & $\begin{array}{c}\text { Content } \\
\text { Mean }\end{array}$ & $\begin{array}{c}\text { weight } \\
\text { S.D. }\end{array}$ & $(\mathrm{g})$ & $\begin{array}{c}\text { No. of stomachs } \\
\text { Total Non-empty }\end{array}$ & $\begin{array}{c}\text { Bottom } \\
\left.\text { Temp. ( }{ }^{\circ} \mathrm{C}\right)\end{array}$ \\
\hline August 1982 & 5 & 1.179 & 1.188 & 12 & 11 & 9.5 \\
& 10 & 0.592 & 0.711 & 244 & 176 & 11.3 \\
& 13 & 0.165 & 0.422 & 10 & 4 & 12.1 \\
October 1982 & 5 & 0.893 & 1.355 & 33 & 21 & 9.5 \\
December 1982 & 10 & 0.702 & 1.126 & 42 & 29 & 10.8 \\
October 1982 & 13 & 0.186 & 0.432 & 26 & 9 & 14.3 \\
& & & & & & \\
February 1983 & 5 & 0.852 & 0.876 & 17 & 11 & 6.6 \\
& 10 & 0.730 & 0.690 & 9 & 6 & 6.3 \\
& 13 & 0.993 & 0.945 & 42 & 37 & 6.2 \\
May 1983 & 5 & 0.816 & 1.101 & 30 & 24 & 6.5 \\
& 10 & 0.340 & 0.561 & 102 & 51 & 7.9 \\
& 13 & 0.912 & 1.576 & 27 & 21 & 7.5 \\
\hline
\end{tabular}

Table 3-3. Yellowtail flounder density (fish hectare ${ }^{-1}$ )*

\begin{tabular}{|c|c|c|c|c|}
\hline Method & Date & 5 & $\begin{array}{c}\text { Station } \\
10\end{array}$ & 13 \\
\hline $\begin{array}{l}\text { Area trawled } \\
\text { (stomach- } \\
\text { collection } \\
\text { cruises) }\end{array}$ & $\begin{array}{l}\text { August } 1982 \\
\text { Oct., Dec. } 1982 \\
\text { February } 1983 \\
\text { May } 1983\end{array}$ & $\begin{array}{l}0.42 \\
0.97 \\
1.20 \\
0.87\end{array}$ & $\begin{array}{r}11.74 \\
1.99 \\
0.43 \\
2.66\end{array}$ & $\begin{array}{l}0.27 \\
0.75 \\
2.48 \\
2.05\end{array}$ \\
\hline $\begin{array}{l}\text { Area trawled } \\
\text { (research survey) }\end{array}$ & Fall 1982 & 5.30 & 5.30 & 1.90 \\
\hline Catch data & Fa11 1982 & 20.07 & 20.01 & 41.34 \\
\hline
\end{tabular}

* 1 hectare $=10^{4} \mathrm{~m}^{2}$ ) 
1984). The research-survey data come from the fall groundfish survey and are expressed as mean number per standardized tow; the commerclal-catch data are simply numbers landed. There are five major yellowtall flounder fishing grounds: Gulf of Maine, Cape Cod, Georges Bank, Southern New England and Mid Atlantic. These populations are more or less discrete and their catch statistics are compiled separately. Stations 5 and 10 are on Georges Bank and Station 13 is in the area inhabited by the Southern New England population. Therefore, I estimated the size of both these populations.

This method smooths the relative abundance index and estimates a catchability coefflcient relating the mean catch-per-tow to total population size. Observed and estimated catches per-tow-are plotted, for the Georges Bank and Southern New England populations, in Figs. 3-3 and 3-4, respectively. Population size is obtained by dividing the estimated relative-abundance index by the catchability coefficient. The population estimates, for fall 1982, are: 64.9 million flsh for Georges Bank and 117.0 million f1sh for Southern New England.

These population estimates apply to the area from which the commercial catch was taken. This area is bounded by the 100-m isobath because yellowtall flounder are rarely caught below this depth (Lux and Livingston 1982). I summed the areas of the approprlate survey strata for each of the two flounder populations. The survey strata corresponding to the Georges Bank population are numbers 13, 16, and 19 to 21 , with a total area of $32,329 \mathrm{~km}^{2}$. Yellowtail flounder density on Georges Bank in fall 1982 was thus $20.07 \mathrm{flsh}$ hectare ${ }^{-1}$. For the Southern New England population, the corresponding survey strata are numbers 5,6,9 and 10 with a total area of $28,294 \mathrm{~m}^{2}$. This gives a 1982 yellowtail flounder density of 41.34 fish hectare ${ }^{-1}$. 


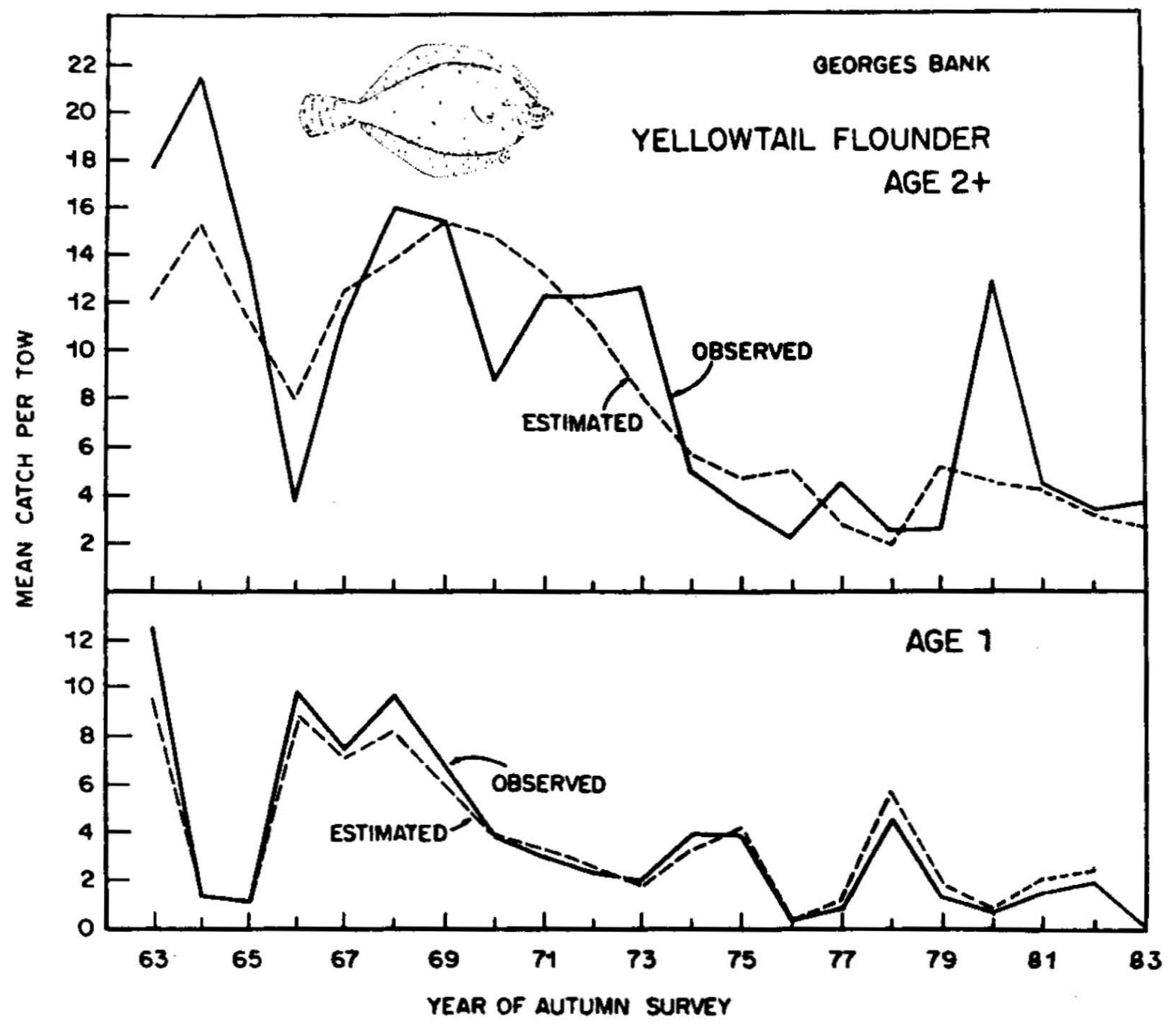

Figure 3-3. Relative abundance of Georges Bank yellowtail flounder in the NEFC groundfish survey. Redrawn from Collie and Sissenwine (1983). 


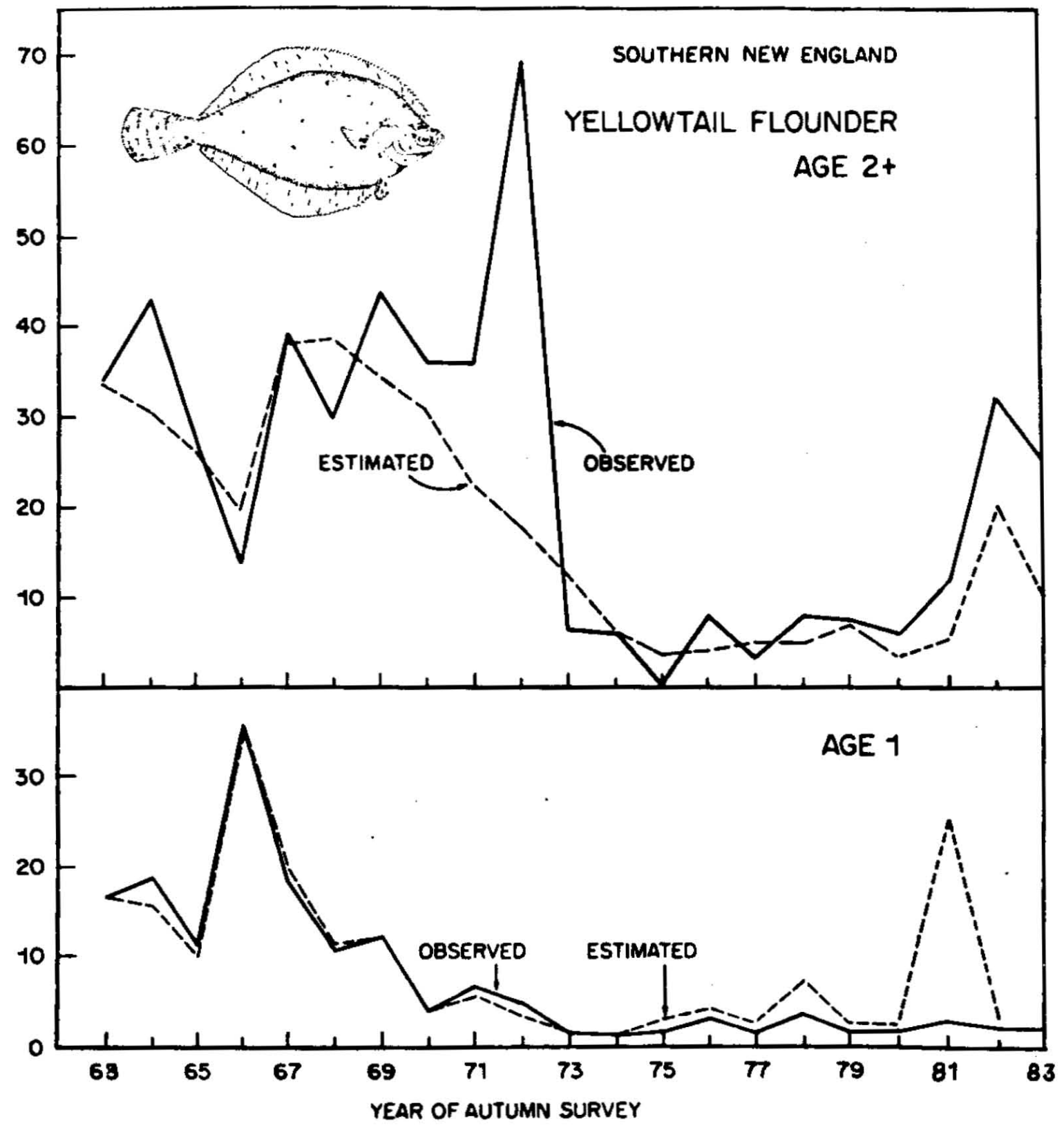

Figure 3-4. Relative abundance of Southern New England yellowtail flounder in the NEFC groundfish survey. Redrawn from Collie and Sissinwine (1983). 
Yellowtail flounder density as estimated by the Collie and Sissenwine method is substantially higher than those estlmates based on area trawled (Table 3-3). This is not surprising because the latter method is known to underestimate true density. I have used the catch-data estimates in subsequent calculations. To calculate consumption rate per unit area, I multiplied these density estimates by the consumption rate per fish. I used the estimates based on stomach contents as lower ranges of consumption and the estimates based on bioenergetics as upper ranges. This, in turn, gives a range for consumption per unit area (Table 3-4). Annual production rates of six important prey species are listed in Table 3-5. The amphipod production rates, in wet-weight units, are from Appendix A. I used the mean of production at Stations 5-1 and 5-28 for Unciola inermis and Ericthonius fasciatus. Data for the sand dollar, Echinarachnius parma, are listed in Collie and Curran (1985). I took the E. parma annual production rate from Table 20 and converted it to grams wet weight using the composition data in Table 19.

Pooled size-frequency data for Chone infundibuliformis at Station 13 are plotted in Fig. 2-10. I standardized the frequencles from the benthic grab samples to number per $\mathrm{m}^{2}$ before applying the sizefrequency method (Eq. 3-8) to estimate production. The production and biomass calculations are given in full in Appendix C; production was 6.60 $g$ wet weight (ww) $\mathrm{m}^{-2} \mathrm{yr}^{-1}$ and $\mathrm{P} / \mathrm{B}$ was $2.83 \mathrm{yr}^{-1}$.

I used this $\mathrm{P} / \mathrm{B}$ value to estimate $\underline{\mathrm{C}}$. infundibuliformis production at Station 5 (from where size measurements were not made). Mean $\underline{C}$. Infundibuliformis biomass at Stations $5-1$ and 5-28 was $0.468 \mathrm{gww} \mathrm{m}^{-2}$. I multiplied this figure by 1.15 to account for weight loss due to preservation of the worms in alcohol, and multiplied the corrected biomass by $\mathrm{P} / \mathrm{B}$ to get the production estimate of $1.52 \mathrm{gww} \mathrm{m}^{-2} \mathrm{yr}^{-1}$. 
Table 3-4. Yellowtall flounder consumption rates (wet welght).

\begin{tabular}{lccc}
\hline & 5 & $\begin{array}{c}\text { Station } \\
10\end{array}$ & 13 \\
\hline $\begin{array}{c}\left.\text { Consumption per fish (kg yr }{ }^{-1}\right) \\
\text { Bioenergetic method } \\
\text { Stomach-content method }\end{array}$ & 1.60 & 1.37 & $\begin{array}{l}1.53 \\
\text { Yellowtail flounder density } \\
\text { (fish m }\end{array}$ \\
$\begin{array}{c}\text { Consumption per unit area } \\
\left(\mathrm{g} \mathrm{m}^{-2} \mathrm{yr}^{-1}\right)\end{array}$ & $2.01 \times 10^{-3}$ & $2.01 \times 10^{-3}$ & $4.13 \times 10^{-3}$ \\
\hline
\end{tabular}

Table 3-5. Yellowtall flounder consumption as a percentage of prey production. ( $g w w=$ grams wet welght)

\begin{tabular}{|c|c|c|c|c|}
\hline Prey species & Station & $\begin{array}{l}\text { Production } \\
\left(\text { gww } \mathrm{m}^{-2} \mathrm{yr}^{-1}\right) \\
\text { Jul } 82-\mathrm{Jul} 83\end{array}$ & $\begin{array}{l}\text { Percent of } \\
\text { flounder diet } \\
\text { (by weight) }\end{array}$ & $\frac{\text { Consumption }}{\text { Production }}$ \\
\hline Unciola inermis & 5 & 8.93 & 31.8 & $5.88-11.50$ \\
\hline Ericthonius fasciatus & 5 & 13.08 & 18.8 & $2.37-4.64$ \\
\hline$\frac{\text { Chone }}{\text { infundibuliformis }}$ & 5 & 1.52 & 9.8 & $10.64-20.83$ \\
\hline C. Infundibuliformis & 13 & 6.60 & 35.4 & $10.62-33.90$ \\
\hline Nephtys Incisa & 13 & 6.02 & 20.1 & $6.61-21.10$ \\
\hline Ampelisca agassizi & 13 & 11.58 & 5.2 & $0.89-2.84$ \\
\hline Echinarachnius parma & 10 & 97.14 & 2.6 & $0.03-0.07$ \\
\hline
\end{tabular}


I used the same approach to estimate production of Nephtys incisa at Station 13. Again, I multiplied the mean biomass of $2.285 \mathrm{gww} \mathrm{m}^{-2}$ $\mathrm{yr}^{-1}$ by 1.15 before applying the $\mathrm{P} / \mathrm{B}$ values of 2.16 (Sanders 1956) and 2.23 (Howe and Leathem 1984). The resulting production estimate ranges from 5.92 to $6.12 \mathrm{gww} \mathrm{m}^{-2} \mathrm{yr}^{-1}$; I used the mean value (Table 3-5) in subsequent calculations.

F1g. 2-5 shows the mean biomass per flounder stomach of the five most important prey species at each station. These data, converted to percent of total stomach-content weight, are listed in Table 3-5. I applied these percentages to consumption per unit area as listed for each station in Table 3-4. Finally, I divided the consumption rates for each species by the corresponding prey production rates to obtain the final colum of Table 3-5. Consumption as a percent of prey poduction was highest for the two polychaete spectes, intermediate for the three amphipod species, and insignificantly low for the sand dollar. 
DISCUSSION

The diel pattern in stomach-content weight (Fig. 3-1) is consistent with that reported in two prevlous studies of yellowtail flounder food habits. Bowman (1980) studied the feeding chronology of demersal fish at a site on southern Georges Bank situated about midway between Stations 5 and 10. Yellowtall flounder stomachs were fullest between 18:00 and 21:00 hours; stomach-content weight decreased from 21:00 to 3:00 hours (Bowman 1980, Fig. 5). Surprisingly, smaller flounder (mean $23 \mathrm{~cm}$ ) had more food in their stomachs than larger (mean $36 \mathrm{~cm}$ ) flounder. Langton (1983) studied the food habits of yellowtall flounder collected during NEFC groundfish surveys from 1973 to 1976. Stomach-content weight was highest from 15:00 to 21:00 hours and lowest from 3:00 to 12:00 hours (Langton 1983, Fig, 1).

These two studies and my results indicate that yellowtail flounder are daytime feeders with peak food consumption in the afternoon to early evening hours. Some flounder probably feed at a slower rate throughout the day and night. In the evening, stomach contents accumulate faster than they are digested, resulting in the stomach-content weight maximum. Bowman (1980) suggested that yellowtail flounder are visual feeders that also use olfaction to locate their prey.

Catchability of yellowtall flounder is higher at night than during the day (Bowman 1980). My results confirm this pattern in that catches were higher at night than day. It is unclear whether increased catchability at night is due to increased activity or to decreased avoidance.

The change-in-stomach-content method of estimating consumption is equivalent to the mean-stomach-content method provided that stomach- 
content weight is roughly the same at the beginning and end of the feeding cycle. In my study, the assumption of a diel feeding pattern was fulfilled and the two methods produced simllar results in the two cases to which they both were applied. This justifled the use of the meanstomach-content method in cases with small sample sizes.

Langton (1983) found that yellowta1l flounder, mean stomach-content weight was higher in the spring, prior to spawning, than in the fall and that mean weight per stomach was higher on Georges Bank than in the Southern New England area. Efanov and Vinogradov (1973) also noted that yellowtall flounder feed more intensively on Georges Bank than they do in Southern New England. My consumption-rate estimates, based on stomach contents (Table 3-4), are consistent with the two previous studies. Consumption at Station 13 (Southern New England) was lower than consumption at Stations 5 and 10 (Georges Bank).

Consumption, as estimated by Eq. 3-6, is the product of mean stomachcontent weight and evacuation rate. At Station 13, mean stomach-content weight was higher in the spring, prior to spawning, but this trend was not apparent at the other two stations. Because the evacuation rate is a function of temperature, it is higher in summer and fall than in winter and spring. No clear seasonal trend in consumption rate is apparent in Fig. 3-2. Consumption at Stations 5 and 10 was highest in summer and fall owing to the warm temperatures, while consumption at Station 13 was lowest in summer and fall because of low stomach-content weights.

Jones (1978) calculated annual consumption of cod and haddock based on energy requirements and on stomach-content weights. Both methods gave results of the same order of magnitude, and there was no systematic difference between the two. For haddock, the bloenergetic method gave a higher consumption estimate than the stomach-content method; for cod, the 
reverse was true. In my study consumption estimates based on bioenergetics were at least twice as high as estimates based on stomach contents. The main uncertainty in the bloenergetic method is in estimating the amount of respiration due to activity. Grossiein et al. (1980) assumed that active metabolism requires twice the energy of resting metabolism.

Compared to the other consumption rates in Table $3-1$, especially those for winter flounder, the bloenergetic estimate for yellowtall flounder does not seem too high. It is more 11kely that the stomach-content estimates are too 1ow. The fish stomachs were fixed in formalin and transferred to alcohol before the contents were weighed; one explanation for the low estimates is that the preservatives could result in a weight loss of $15 \%$ or more (Mills et al. 1982).

The population-density estimates based on area trawled, though not useful in calculating consumption per unit area, Indicate the efficiency of the otter trawl and the relative catchability of flounder at different seasons and sites. Comparing the minimum population estimates from the fal1 1982 survey to those based on catch data, I calculated that the otter trawl was 10 to $25 \%$ efficient in catching yellowtall flounder. Flounder catch-per-tow on the stomach-collection cruises was usually lower than catch-per-tow in the same stratum on the groundfish survey. This observation highlights out the difficulty in obtaining repeated catches of a mobile, migratory predator from fixed locations.

The population abundances based on catch statistics cannot be gross overestimates because there must have been at least as many yellowtail flounder as the number caught commerclally. The main weakness in this approach is that the estimates of flounder density apply to several survey strata that may not equally represent the benthic monitoring 
stations. Although catch per tow is tabulated stratum by stratum, there is no obvious way of welghting the Collie and Sissenwine (1983) method in order to estimate fish abundance in one particular stratum.

A potential source of error in the Chone infundibuliformis data is

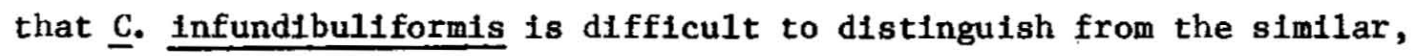
but smaller, congeneric species, $\underline{\text {. }}$ duneri. Juvenile $\underline{C}$. Infundibuliformis may have been misidentified or not identified to species (Blake and Baptiste 1985). This identification problem does not invalidate the C. Infundibuliformis results in this thesis, provided that Chone in the fish stomachs were identifled by the same criteria as those in the grab samples. If I assume, for sake of arguement, that all large Chone were called $\underline{C}$. Infundibuliformis and all small ones were called $\underline{C}$. duneri, it would be the same as having two size groups of one species. If juveniles were misidentified, the estimate of $\underline{c}$. Infundibuliformis production may be two low, but it still applies to the size range eaten by flounder. The $\mathrm{P} / \mathrm{B}$ value of $2.83 \mathrm{yr}^{-1}$ is as high as the $\mathrm{P} / \mathrm{B}$ values of other annual species, so this potential underestimate may not be important.

The results in Table 3-5 imply that food consumption by yellowtail flounder is not 1imited by prey production because there is excess prey production not utilized by flounder. Figs. 3-3 and 3-4 show that yellowtail flounder population size was much lower from 1981 to 1983 compared to the earlier period, 1963 to 1965. The flounder population is especially reduced on Georges Bank; in the Southern New England area, flounder abundance has increased thanks to the strong 1980 year class. According to Grosslein et al. (1980), yellowtall flounder consumption per unit area on Georges Bank was $5.8 \mathrm{~g} \mathrm{~m}^{-2} \mathrm{yr}^{-1}$ from 1964 to 1966 and $4.4 \mathrm{~g} \mathrm{~m}^{-2} \mathrm{yr}^{-1}$ from 1973 to 1975 . 
Using my population estimates I calculated consumption by flounder as 6.0 to $11.7 \mathrm{~g} \mathrm{~m}^{-2} \mathrm{yr}^{-1}$ in 1963. My estimates are higher than those of Grosslein et al. (1980) because, in calculating flounder density, I used the area of strata where yellowtall flounder are caught instead of the entire area of Georges Bank. At the 1963 population level, if consumption rate per fish and prey-production rates equalled 1982 levels, the consumption rates in Table 3-5 would be increased by a factor of 3.6. Given these assumptions, yellowta11 flounder would consume 21.2 to $41.4 \%, 8.5$ to $16.7 \%$ and 38.3 to $75.0 \%$ of the annual production of Unciola Inermis, Erlcthonius fasclatus and Chone infundibuliformis, respective1y. At these consumption levels, prey production could limit feeding. If yellowtall flounder feeding were limited by prey production, one would expect that the hypotheses Persson (1981) proposed for the Baltic Sea would apply to Georges Bank. These hypotheses state that as flounder abundance decreases, individual growth rates should increase because of decreased competition for food, and the biomass of benthic macrofauna should increase. To test the growth-rate hypothesis, I plotted mean length at age of yellowtall flounder caught during the fall groundfish survey from 1963 to 1983 (Fig. 3-5). I plotted mean lengths for ages 1, 2 and 3 only, because the sample sizes of older ages are too sma11. On the average, mean lengths-at-age were higher from 1974 to 1983 when flounder were less abundant, and lower from 1963 to 1973 when flounder were more abundant. However, there is a good deal of year-to-year variability not explained by the density-dependent growth rate hypothesis. Although several Georges Bank surveys have measured benthlc biomass (e.g. Wigley 1968, Michael et a1. 1983, Battelle and WHOI 1984), a direct comparison of the results is hampered by the fact that different stations were sampled and different methods were used on each survey. One problem 


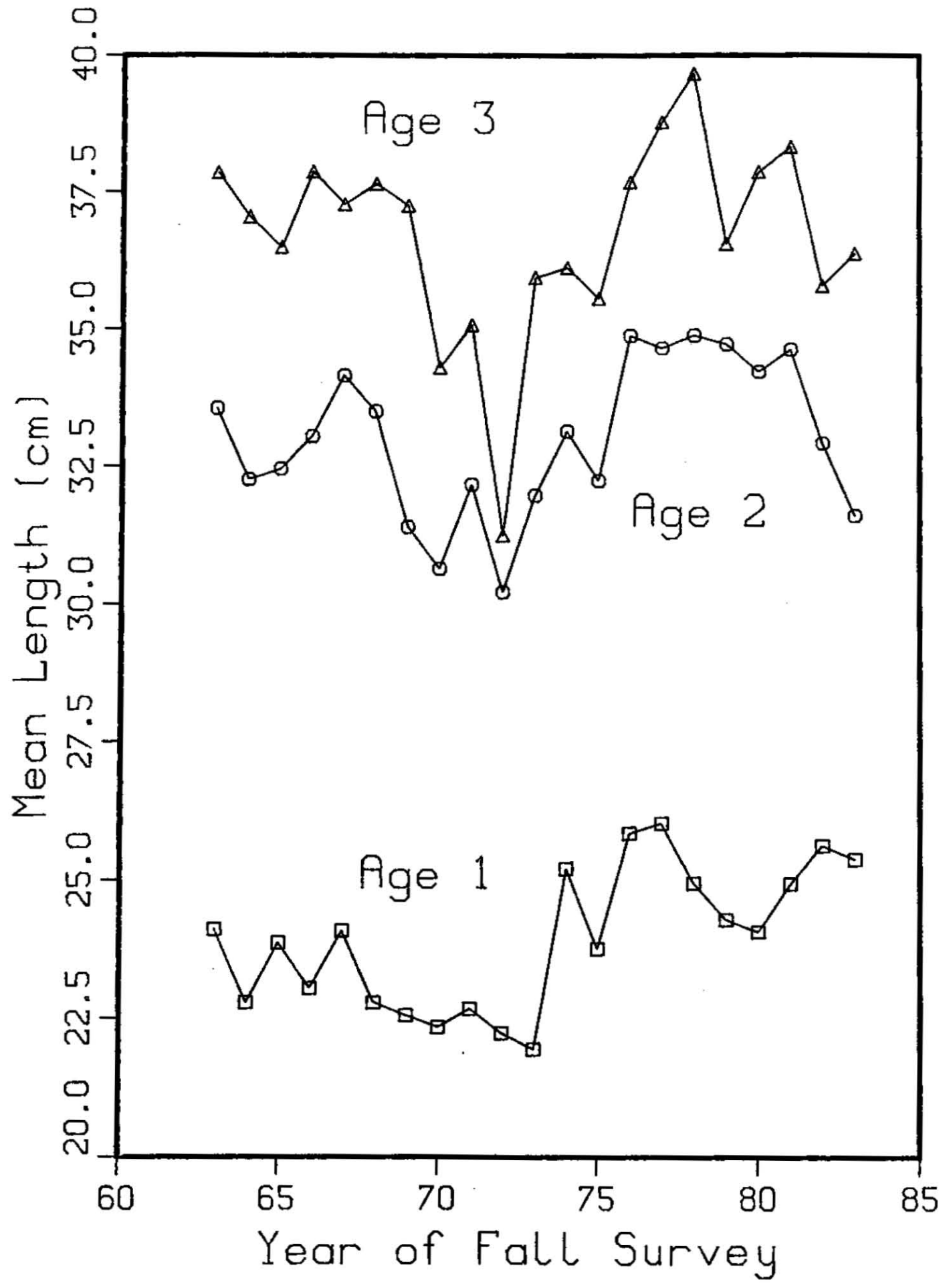

Figure 3-5. Mean length-at-age of Georges Bank yellowtail flounder in the NEFC groundfish survey. These data were provided courtesy of Margaret McBride, NEFC. 
with wet-welght biomass data is that a few large species with hard parts, such as Arctica islandica and Echinarachnius parma, completely dominate the blomass. Only juventles of these species are small enough for flounder to eat. Even if the weights of these large species are excluded, methodological differences preclude a valid comparison among benthic surveys. On more recent surveys, increasingly finer sieves, which retain more animals, have been used. Thus, biomass may appear to Increase regardless of real changes in the benthos.

The results in Table 3-5 show that yellowtail flounder consume a significant proportion (up to $33 \%$ ) of the production of 1mportant prey species. To some extent, flounder may thus regulate the abundance of benthic macrofauna. What is the fate of the remaining portion of prey production, not consumed by flounder? Much of the production is probably consumed by other fish and by invertebrate species.

Following is a list of some benthivorous fish species and their diet compositions as analyzed by Bowman and Michaels (1984). The numbers in parentheses are percentages by weight of different food types in the predator's diet. Amphipod feeders include 1ittle skate (14.0\%), haddock (7.5\%), red hake (5.0\%) and scup (7.2\%). Ampelisca 8pp., Unctola spp. and Ericthonius spp. were among the most numerous prey of these fish. Additionally, the juveniles of some flsh, such as cod and silver hake, feed on amphipods, switching to larger prey as adults.

Polychaete feeders include Ifttle skate (10.7\%), haddock (18.1\%), scup $(39.1 \%)$, butterfish $(12.8 \%)$ and witch flounder $(62.1 \%)$. Worms of the families Sabellidae, Nephtyidae and Lumbrineridae were Important prey for these fish. Two fish specles that specialize in eating the sand dollar, Echinarachnius parma, are ocean pout (82.5\%) and American plalce $(66.2 \%)$. 
Although the diets of these fish specles are well documented, consumption rates and abundances can be calculated only for a few of them. The combined predation by this guild of benthic-feeding fish may be substantlally more than that of yellowtall flounder alone. Together, these predators could regulate the abundance of their benthic prey. 
$-130-$ 
CONCLUS IONS

Results of the life-history analysis aided in interpreting changes in species abundance observed during the Georges Bank Benthic Infauna Monitoring Program. Much of the variation in amphipod abundance was explained on the basis of recruitment and subsequent mortality, although adult migration may be important in explaining population changes in . Ericthonius fasciatus. Production of benthic amphipods at the stations investigated was as high ( 1.3 to $\left.3.2 \mathrm{gdw} \mathrm{m}^{-2} \mathrm{yr}^{-1}\right)$ as production by related near-shore species with similar life-spans. The seasonal variation in amphipod growth rates (Fig. 1-8) can be fit remarkably well by a sine curve (not shown) that is in phase with the annual primary production cycle on Georges Bank ( $0^{\prime}$ Reilly et al., in press). The high production rates and coupling of amphipod growth to primary production indicate that phytodetritus reaches the bottom and is utilized by amphipods.

Stomach-content analysis confirmed the importance of benthic macrofauna in the diet of yellowtail flounder on Georges Bank. Although the flounder diet is broad, feeding is by no means random. Yellowtail flounder select suitably sized prey that live on or near the sediment surface. The composite size-selection curve (Fig, 2-15) is consistent with Andersen's (1982) hypothesis of a log-normal selection function. Different prey species dominated the yellowtail founder diet at different dates and stations. The selectivity indices showed that, in general, diet composition changed seasonally in relation to variations in benthic species abundance. This means that predation patterns are predictable on the basis of prey species and prey size. There was, however, residual variation in diet composition not explained by 
selection indices. Pelagic prey were eaten in the absence of suitable benthic prey.

I estimated yellowtail flounder consumption rates with two different methods. The method based on bioenergetics gave consistently higher results ( 1.4 to $1.6 \mathrm{~kg} \mathrm{fish}^{-1} \mathrm{yr}^{-1}$ ) than the method based on stomachcontent weight $\left(0.5\right.$ to $\left.0.8 \mathrm{~kg} \mathrm{fish}{ }^{-1} \mathrm{yr}^{-1}\right)$. Using estimates of yellowtall flounder density (Table 3-4), I converted these consumption rates to consumption per unit area. At 1982 population densities, prey production did not appear to limit flounder feeding (Table 3-5) although yellowtail flounder may compete for prey with other benthic feeders. Prey production may have limited feeding in the 1960s when yellowtail flounder were more abundant than at present (Figs, 3-3 and 3-4). There is slight evidence that flounder growth rates have increased in response to lower population densities (F1g. 3-5). Predation by yellowta11 flounder is a small but significant source of mortality on the prey populations (Table 3-5). Consumption by all benthic-feeding fish species could account for most of the prey production.

Together, the three chapters present a consistent picture of the prey species' 11 fe-history strategies. Chapter Two showed that predation on amphipods was highly size selective. Yellowtail flounder selected adult aphipods and neglected the juveniles. The mortality rates of adult amphipods (Figs. 1-3 to 1-5) appear to be higher than the mortality rates of juveniles. This observation is consistent with the size-selective pattern of flounder predation.

Of the three amphipod species, Ampelisca agassizi lives longest, grows slowest, and has the 1owest $P / B$ (Table 1-7). The tubes of A. agassizi extend vertically into the substratum, providing a refuge from predation. Compared to the other amphipod species, A. agassizi is 
selected against at all sizes (Fig. 2-15) and only a small proportion of 1ts annual production is consumed by yellowtall flounder (Table 3-5). In contrast, Ericthonius fasclatus has the shortest 11 fe-span, fastest growth rate and highest $P / B$. E. fasclatus is an epifaunal tube builder and is thus more vulnerable to predation. Compared to the other two amphipod species, E. fasciatus is selected for at all lengths. However, E. fasclatus does not grow as big as the other species and much of its production occurs in the small size classes not preferred by flounder.

Unciola inermis is intermediate in these 1ife-history traits. Its tubes are usually built into the substratum and are thus less exposed to predation. $\underline{U}$. Inermis grows to a larger maximum weight than the other amphipods and therefore, more of 1 ts production is in the size classes preferred by flounder. In summary, the trade-off between growth rate and life-span seems to be mediated by predation.

Yellowtall flounder, eating intermediate sizes of Echinarachnius parma (Fig. 2-9), accounted for an insignificant proportion of annual sand dollar production (Table 3-5). Most E. parma are too large for flounder to eat. Fish predation on intermediate-sized sand dollars could account for the absence of those sizes in the benthos and thus for the perlodic recruitment pattern exhibited by $\underline{E}$. parma.

The polychaete, Chone Infundibuliformis, appears to be the optimal prey size -- all its size classes were positively selected by yellowtail flounder (Fig. 2-15). Of the six prey specles in listed Table 3-5, c. 㕶fundibuliformis had the highest proportion of its production consumed by flounder. Thus, the selection Index, as calculated in Chapter Two, is consistent with the Impact of predation, as calculated in Chapter Three. 


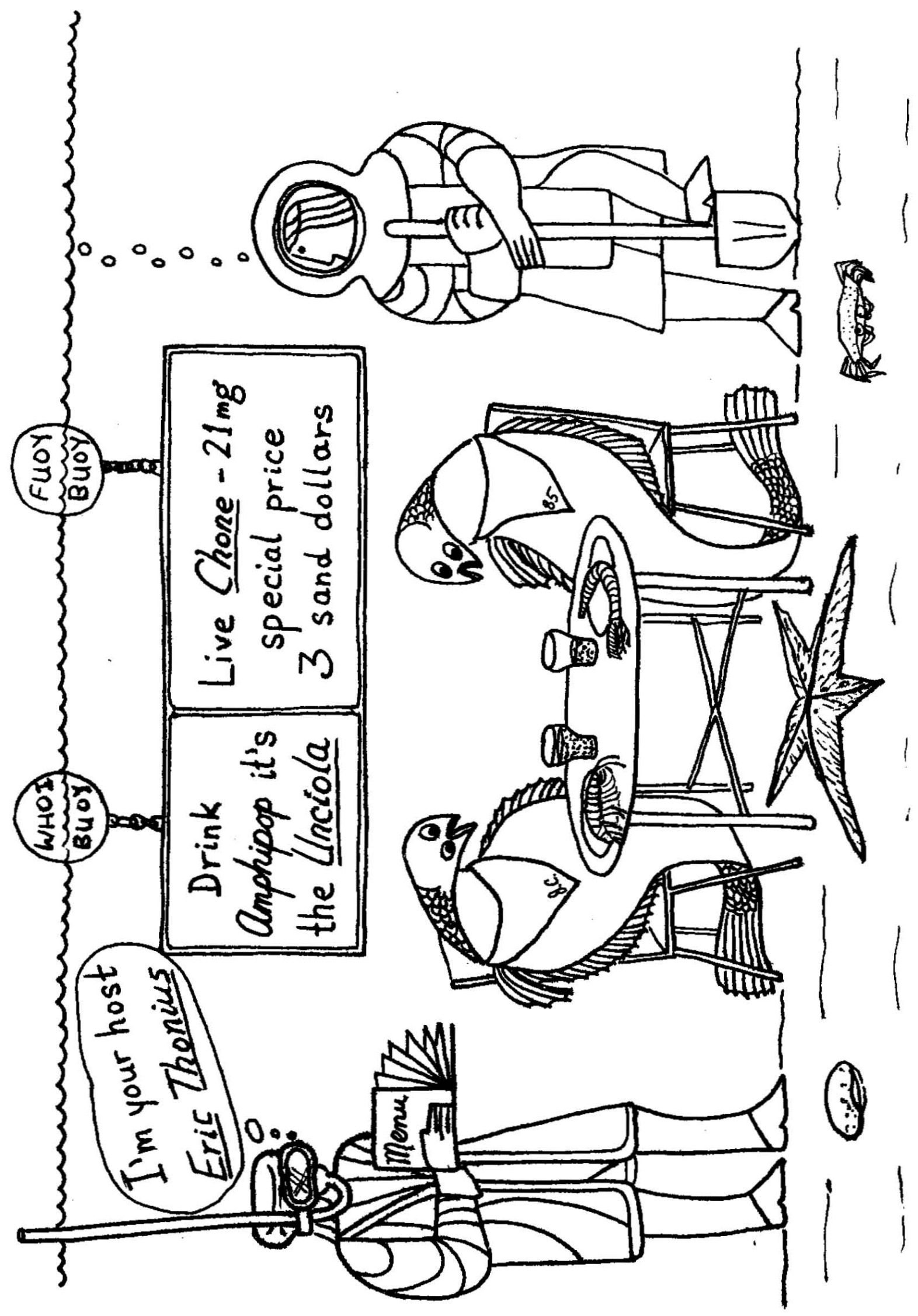




\section{REFERENCES}

Albright, R. and D. Armstrong. 1982. Population dynamics and production of the amphtpod Corophium salmonis in Grays Harbor, Washington. Tech. Rep. to Washington Game Dept. and U.S. Army Corps of Engineers.

Andersen, K.P. 1982. An interpretation of the stomach contents of fish in relation to prey abundance. Dana 2: 1-50.

Arntz, W. E. 1980. Predation by demersal fish and its impact on the dynamics of macrobenthos. In: K.R. Tenore and B.C. Coull (eds.), Marine Benthic Dynamics. University of South Carolina Press, Columbia. pp. 121-150.

Arntz, W.E. and E. Ursin. 1981. Estimates of food consumption parameters for dab Limanda limanda utilizing information on food concentrations. An application of Andersen's stomach analysis model. ICES CM 1981/L: 41 .

Backus, R.H. (ed.) In press. Georges Bank. MIT Press, Cambridge, Mass.

Battelle and WHOI. 1984. Georges Bank Benthic Infauna Monitoring Program. Final Report, Year Two. To USDI, Mineral Management Service, Washington D.C. Battelle and Woods Hole Oceanographic Institution.

Battelle and WHOI. 1985. Georges Bank Benthic Infauna Monitoring Program. Final Report, Year Three. To USDI, Minerals Management Service, Washington, D.C. Battelle and Woods Hole Oceanographic Institution.

Beyer, J. and P. Sparre. 1983. Modelling exploited fish stocks. In: S.E. Jorgensen (ed.), Application of Ecological Modelling in Environmental Management. Developments in, Environmental Modelling Ser.: Vol 4A. Elsevier, Amsterdam.

Bigelow, H. B. and W.C. Schroeder. 1953. Flshes of the Gulf of MaIne. U.S. Fish wild1. Serv., Fish. Bull. 53, 577 pp.

Birklund, J. 1977. Biomass, growth and production of the amphipod Corophium Insidiosum (Crawford) and preliminary notes on Corophium volutator (Pallas). Ophella 16: 187-203.

Blake, J.A. and E.M. Baptiste. 1985. Life history studies on dominant polychaete species from Georges Bank. In: Battelle and WHOI, Georges Bank Benthic Infauna Monitoring Program, Final Report, Year Three, to USDI, Minerals Management Service, Washington, D.C. Battelle and Woods Hole Oceanographic Institution. pp. 140-178.

Bousfleld, E.L. 1973. Shallow water Gammaridean Amphipoda of New England. Cornell University Press, Ithica, N.Y. 312 pp.

Bowman, R.E. 1980. Diurnal perlodicity in the feeding and catchability of some marine fish and squid. Nat. Mar. F1sh. Serv., Woods Hole Lab. Ref. Doc. No. 80-17, 26pp. 
Bowman, R.E., and W.L. Michaels. 1984. Food of seventeen species of Northwest Atlantic fish. NOAA Tech. Mem. NMFS-F/NEC-28.

Bradford, J.M. 1975. New parasitic Chonlostomatidae (Copepoda) mainly from Antarctic and Subantarctic Ostracoda. New Zealand Oceanographic Institute Memoir No. 67.

Carrasco, F.D. and D.F. Arcos. 1984. Life history and production of a cold temperate population of the sublittoral amphipod Ampelisca araucana. Mar. Ecol. Prog. Ser. 14: 245-252.

Casabianca, M.L. de. 1975. Methode de calcul de la production par estimation de la mortalite. Application a une population a structure complex du crustace Corophium insidiosum Crawford (Lagune de Biguglia, Corse). c. r. Lebd. Seances Acad. Sc1. 280D : 1134-1142.

Cederwa11, H. 1977. Annual macrofauna production of a soft bottom in the northern Baltic proper. In: B.F. Keegan, P. O Celdigh and P.J.S. Boaden (eds.), Biology of Benthic Organisms. Pergamon Press, London. pp. 155-164.

Chesson, J. 1978. Measuring preference in selective predation. Ecology 59: 211-215.

Clark, S.H., M.M. Mcbride and B. Wells. 1984. Yellowtail flounder assessment update--1984. Nat. Mar. Fish. Serv., Woods Hole Lab. Ref. Doc. No. 84-39, 30pp.

Collie, J.S. 1985. Life history and production of three amphipod species on Georges Bank. Mar. Ecol. Prog. Ser. 22: 229-238.

Collie, J.S. and M.C. Curran. 1985. Benthic production and fish feeding. In: Battelle and WHOI, Georges Bank Benthic Infauna Monitoring Program, Final Report, Year Three, to USDI, Minerals Management Service, Washington, D.C. Battelle and Woods Hole Oceanographic Institution. pp. 179-228.

Collie, J.S. and M.P. Sissenwine. 1983. Estimating population size from relative abundance data measured with error. Can. J. Fish. Aquat. Sc1. 40: 1871-1879.

Crisp, D. J. (1984), Energy flow measurements. In: Holm, N.A., and McIntyre, A.D. (eds.) Methods for the Study of Marine Benthos, 2nd Edition. IBP Handbook No. 16, Blackwel1, Oxford. pp. 284-372

Cushing, D.H. 1981. Fisheries Biology. The University of Wisconsin Pess, Madison. 295 pp.

Daan, N. 1973. A quantitative analysis of the food intake of North Sea Cod, Gadus morhua. Neth. J. Sea Res. 6: 479-517.

Dauvin, J.C. 1979. Recherches quantatives sur le peuplement des sables fins de la Plerre Nolre et sur sa perturbation par les hydrocarbares de 1 'Amoco Cadiz. These Doct. Beme Cycle, Univ. P. \& M. Curle, Paris, $251 \mathrm{pp}$. 
Dauvin, J.C. 1984. Dynamique d'ecosystemes macrobenthiques des fonds sedimentaires de la baie de Morlalx et leur perturbation par les hydrocarbures de 1'Amoco Cadiz. These Doct. d'Etat Es-sciences Nat., Univ. P. \& M. Curie, Paris, 468 pp.

Dekker, W. 1983. An application of the Andersen consumption model in estimating prey size preference in North Sea cod. ICES CM 1983/G: 63.

Dickinson, J.J. and Roland L. Wigley. 1981. Distribution of Gammaridean Amphipoda (Crustacea) on Georges Bank. U.S. Dept. Commerce. NOAA Tech. Rep. NMFS SSRF-746, 25 pp.

Dickinson, J.J., R.L. Wigley, R.D. Brodeur and S. Brown-Leger. 1980. Distribution of Gammaridean amphipoda (Crustacea) in the Middle Atlantic Bight Region. U.S. Dept. Commer. NOAA Tech. Rep. NMFS SSRF-741, $46 \mathrm{pp}$.

Donn, T.E. and R.A. Croker. 1983. Production ecology of Haustorius canadensis in southern Maine. In: A. McLachlan and T. Erasmus (eds.), Sandy Beaches as Ecosystems. W. Junk Publishers, Boston. pp. 661-667.

Durbin, E.G., A.G. Durbin, R.W. Langton and R.E. Bowman. 1983. Stomach contents of silver hake, Merluccius bilinearis, and Atlantic cod, Gadus morhua, and estimation of their dally rations. Fish. Bull. U.S. 81: $437-454$.

Efanov, V.N. and V.I. Vinogradov. 1973. Feeding patterns of yellowta1l of two New England stocks. Int. Comm. Northwest At1. Fish., Redb. Part III, pp. 75-77.

Eggers, D. M. 1977. Factors in interpreting data obtained by diel sampling of fish stomachs. J. Fish. Res. Board Can. 34: 290-294.

Eggers, D.M. 1979. Comment on some recent methods for estimating food consumption by fish. J. Fish Res. Board Can. 36: 1018-1019.

E1liot, J.M. and L. Persson. 1978. The estimation of dally rates of food consumption for fish. J. Anim. Eco1. 47: 977-991.

Evans, Sverker. 1984. Energy budgets and predation Impact of dominant epibenthic carnivores on a shallow soft-bottom community on the Swedish west coast. Estuar. Coast. Shelf. Sc1. 18: 651-672.

Fange, R. and D. Grove. 1979. Digestion. In: W.S. Hoar, D.J. Randall and J.R. Brett (eds.), Fish Physiology Vol. VIII: Bioenergetics and Growth. Academic Press, New York. pp. 162-280.

Fauchald, K. and P. Jumars 1979. The diet of worms: a study of polychaete feeding gullds. Oceanogr. Mar. Biol. Ann. Rev. 17: 193-284.

Frame, D.W. 1974. Feeding habits of young winter flounder (Pseudopleuronectes americanus): prey availability and diversity. Trans. Am. Fish. Soc. 103: 261-269.

Gabriel, W.L. and W.G. Pearcy. 1981. Feeding selectivity of Dover sole, Microstomus pacificus, off Oregon. Fish. Bull. U.S. 79(4): 749-763. 
Gillespie, D.M. and A.C. Benke. 1979. Methods of calculating cohort production from field data--some relationships. Limnol. Oceanogr. 24 : $171-176$.

Glemarec, M. and A. Menesguen. 1980. Functioning of a muddy sand ecosystem: seasonal fluctuations of different trophic levels of the dominant macrofauna specles. In: K.R. Tenore and B.C. Coull (eds.), Marine Benthic Dynamics. University of South Carolina Press, Columb1a. pp. 49-68.

Gosner, K.L. 1971. Guide to Indentification of Marine and Estuarine Invertebrates. Wiley-Interscience, New York. 693 pp.

Grosslein M.D. 1969. Groundfish survey program of BCF Woods Hole. Commer. Fish. Rev., 31(8-9): 22-35.

Grosslein, M.D., R.W. Langton and M.P. Sissenwine. 1980. Recent fluctuations in pelagic fish stocks of the Northwest Atlantic, Georges Bank region in relation to species interactions. Rapp. P.-v. Reun. Cons. Int. Explor. Mer 177: 374-404.

Hahm, W. and R. Langton. 1984. Prey selection based on predator/prey weight ratios for some northwest Atlantic fish. Mar. Ecol. Prog. Ser. 19: $1-5$.

Harding, J.P. 1949. The use of probability paper for the graphical analysis of polymodal frequency distributions. J. Mar. Biol. Asso. U.K. 28: 141-153.

Hasselblad, V. 1966. Estimation of parameters for a mixture of normal distributions. Technometrics 8: 431-444.

Hastings, M.H. 1981a. The life cycle and productivity of an intertidal population of the amphipod Ampelisca brevicornis. Est. Coast. Shelf. Sci. 12: $665-677$.

Hastings, M.H. 1981b. Intersex specimens of the amphipod Ampelisca brev1cornis (Costa). Crustaceana 41: 199-205.

Howe, S. and W. Leathem. 1984. Secondary production of benthic macrofauna at three stations of Delaware Bay and coastal Delaware. NOAA Tech. Mem. NMFS-F/NEC-32. $62 \mathrm{pp}$.

Huebner, J.D. and R.W. Langton. 1982. Rate of gastric evacuation for winter flounder, Pseudopleuronectes americanus. Can. J. Fish. Aquat. Sci. 39: 356-360.

Ivlev, V.S. 1961. Experimental Ecology of the Feeding of Fish. Yale University Press, New Haven.

Jensen, P. B. 1919. Valuation of the Limfiord, 1909-1917, its quantity, variation, and annual production. Rep. Danish Biol. Sta. 26: 3-44.

Jones, R. 1978. Estimates of food consumption of haddock (Melanogrammus aeglefinus) and cod (Gadus morhua). J. Cons. Int. Explor. Mer. 38: 18-27. 
Kanneworff, Ebbe. 1965. Life cycle, food, and growth of the amphipod Ampelisca macrocephala (Iil jeborg) from the Oresund. Ophella 2: 305-318.

Kemp, P.F., F.A. Cole and R.C. Swartz. In press. Life history and productivity of the Phoxocephalid amphipod Rhepoxynius abronis (Barnard). J. Crust. Biol.

Kendall, W.C. 1898. Notes on the food of four species of the cod family. Report U.S. Comm. Fish and Fisheries, 1896. pp. 177-186.

Klein, G., E. Rachor and S.A. Gerlach. 1975. Dynamics and productivity of two populations of the benthic tube-dwelling amphipod Ampelisca brevicornis (Costa) in Helgoland B1ght. Ophella 14: 139-159.

Krueger, C.C. and F.B. Martin. 1980. Computation of confidence intervals for the size-frequency (Hynes) method of estimating secondary production. LAmol. Oceanogr. 25: 773-777.

Langton, R.W. 1983. Food habits of yellowtall flounder, Limanda ferruginea (Storer), from off the northeastern United States. Fish. Bull. U.S. $81: 15-22$.

Langton, R.W. and R.E. Bowman. 1981. Food of elght northwestern Atlantic Pleuronectiform fishes. NOAA Tec. Rep. NMFS SSRF-749.

Lechowicz, M.J. 1982. The sampling characteristics of electivity indices. 0ecologia 52: 22-30.

Levings, C.D. 1974. Seasonal changes in feeding and particle selection by winter flounder. Trans. Am. F1sh. Soc. 103: 828-832.

Libey, G.S. and C.F. Cole. 1979. Food habits of yellowtail flounder, Limanda ferruginea (Storer). J. Fish. Biol. 15: 371-374.

Lincoln, R.J. 1979. British Marine Amphipoda: Gammaridea. British Museum (Natural History).

Love, M.S. and A.W. Ebeling. 1978. Food and habitat of three switchfeeding fishes in the kelp forests off Santa Barbara, California. Fish. Bu11. U.S. 76: 257-271.

Lux, F.E. and R. Livingston, Jr. 1982. Yellowta1l flounder Limanda ferruginea, In: M.D. Grosslein and T.R. Azarovitz (eds.), Fish Distribution. MESA New York Bight Atlas Monograph 15. pp. 117-119.

MacDonald, J.S. 1982. Food Resource Partitioning by Five Species of Benthic Feeding Fish in Passamaquoddy Bay N.B. Ph. D. Thesis, University of Western Ontario, London, Canada.

McCain, J.C. 1968. The Caprellidae (Crustacea: Amph1poda) of the Western North Atlantic. U.S. National Museum Bulletin 278.

McNew, R.W. and R.C. Summerfelt. 1978. Evaluation of a maximum-11kelihood estimator for analysis of length-frequency distributions. Trans. Am. Fish. Soc. 107(5): 730-736. 
Michael, A.D., C.D. Long, D. Maurer and R.A. McGrath. 1983. Georges Bank benthic infauna historical study. Final report to U.S. Dept.

Interior, Minerals Management Service, Washington, D.C. by Taxon

Inc., Salem, Mass.

Mills, E.L. 1963. A new species of Ampelisca (Crustacea: Amphipoda) from eastern North America, with notes on other species of the genus. Can. J. Zoo1. 14: 971-989.

Mills, E.L. 1967a. A reexamination of some species of Ampelisca (Crustacean: Amphipoda) from the East Coast of North America. Can. J. Zool. 45: 635-652.

Mi1ls, E.L. 1967b. The blology of an ampeliscid amphipod crustacean sibling species pair. J. Fish. Res. Bd. Can. 24: 305-355.

Mills, E.L. K. Pittman and B. Monroe. 1982. Effect of preservation on the weight of benthic marine invertebrates. Can. J. Fish. Aqaut. Sci. 39: 221-224.

Moller, P., R. Rosenberg. 1982. Production and abundance of the amphipod Corophlum volutator on the west coast of Sweden. Neth. J. Sea Res. 16: $127-140$

Murdoch, W.W., S. Avery and M.E.B. Smyth. 1975. Switching in predatory fish. Ecology 56: 1094-1105.

Myers, A.A. and D. McGrath. 1984. A revision of the north-east Atlantic species of Ericthonius (Crustacea: Amphipoda). J. Mar. Biol. Ass. U.K. $64: 379-400$.

O'Re1lly, J.E., C. Evans-Zetlin and D.A. Busch. In press. Chapter 21 in: R.H. Backus (ed.) Georges Bank, MIT Press, Cambridge, Mass.

Pennington, M. 1981. Estimating the average food consumption by fish in the fleld. ICES C.M. 1981/G: 69 .

Perrson, L. -E. 1981. Were macrobenthic changes induced by thinning out of flatfish stocks in the Baltic proper? Ophe11a 20: 137-152.

Peterson, C.M. 1979. Predation, competitive exclusion and diversity in soft-sediment benthic communities of estuaries and lagoons. In: R.J. Livingston (ed.), Ecological Processes in Coastal and Marine Systems. Plenum Press, New York. pp. 233-264.

Plenaar, L.V. and W.E. Ricker. 1968. Estimating mean welght from length statistics. J. Fish. Res. Bd. Can. 25: 2743-2747.

P1h1, L. 1985. Food selection and consumption of mobile epibenthic fauna in shallow marine areas. Mar. Ecol. Prog. Ser. 22: 169-179.

P1tt, T.K. 1976. Food of yellotall flounder on the Grand Bank and a comparison with American plaice. Int. Comm. Northwest At1. Fish. Res. Bul1. 12: 23-27. 
Pyke, G.H. 1979. Optimal foraging in fish. In: R.M. Stroud and H. Clepper (eds.), Predator-Prey Systems in Flsherles Management. Sport Fishing Institute, ?? pp. 199-202.

Rudde11, C. 1977. Histopathologicxal studies. In: B. Laird (report coordinator), Middle Atlantic Outer Continental Shelf Environmental Studies, Vol. IIB: Chemical and Biological Benchmark Studies. Va. Inst. Mar. Sc1., Gloucester Point. Chap. 10, pp. 1-47.

Sanders, H.L. 1956. Oceanography of Long Island Sound 1952-1954. X: The biology of marine bottom communities. Bull. Bingham Oceanogr. Coll., Peabody Museum of Natural History, Yale University, New Haven, Conn.

Sars, G.0. 1895. Vol. 1 of An Account of the Crustacea of Norway: Amph1poda. Christiana and Copenhagen. 711pp.

Schmitt, R.J. and S.J. Holbrook. 1984a. Ontogeny of prey selection by black surfperch Emblotoca facksoni (P1sces: Emblotocidae): the roles of fish morphology, foraging behavior, and patch selection. Mar. Ecol. Prog. Ser. 18: 225-239.

Schmitt, R.J. and S.J. Holbrook. 1984b. Gape-limitation, foraging tactics and prey size selectivity of two microcarnivorous specles of fish. 0ecologia 63: 6-12.

Sedberry, G.R. III. 1980. Food hablts, prey selectivity, and food resource partitioning of a community of fishes on the outer continental shelf. Ph.D. Thesis, The College of William and Mary, Virginia. 179 pp.

Sheader, M. 1977. Production and population dynamics of Ampelisca tenuicornis (Amphipoda) with notes on the blology of Its parasite Sphaerone11a long1pes (Copepoda). J. mar. biol. Ass. U.K. 57: 955-968

Shoemaker, C.R. 1945. The amphipod genus Unclola on the east coast of America. Amer. Midl. Nat. 34: 446-465

Sissenwine, M.P., E. B. Cohen and M.D. Grosslein. 1982. Structure of the Georges Bank Ecosystem. In: Symposium on Blological Productivity of Continental Shelves in the Temperate Zone of the North Atlantic. No. 31, ICES.

Smith, F. 1950. The benthos of Block Island Sound. 1. The invertebrates, their quantities and their relation to the fishes. Ph.D. Thesis, Yale University, New Haven, Conn. 213pp.

Smith, S. and 0. Harger. 1874. Report on the dredgings in the region of St. Georges Banks, in 1872. Trans. Conn. Acad. Arts Sc1. 3: 1-57.

Steimle, F. (In press) Benthic production on Georges Bank. In: Backus, R.H. (ed.) Georges Bank. MIT Press, Cambridge, Mass.

Tomlinson, P.K. (1971). NORMSEP: Normal distribution separation. In: Abramson, N.J. (ed.) Computer programs for fish stock assessment. FAO Fish. Tech. Pap. 101 (FIRD/T101) FAO, Rome. 
Tyler, A.V. and R.S. Dunn. 1976. Ration, growth, and measure of somatic and organ condition in relation to meal frequency in winter flounder, Pseudopleuronectes americanus, with hypotheses regarding population homeostasis. J. Fish. Res. Bd. Can. 33: 63-75.

Ursin, E. 1981. On K.P. Andersen's interpretation of the stomach contents of a fish. pp. 56-57 in: G.M. Caillet and C.A. Simenstad (eds.), Gutshop ' 81 , Fish Food Habits Studies, Proceedings of the third Pactfic workshop, Pacific Grove, Californta.

Ursin, E. and W.E. Arntz. 1985a. On prey size preference and s1zeindiscriminate feeding of whiting (Merlanglus merlangus). ICES CM 1985.

Ursin, E. and W.E. Arntz. 1985b. The stomach contents of dabs (Limanda limanda) in the Baltic as indicators of different feeding strategles. ICES CM 1985.

Uzmann, J.R., R.A. Cooper, R.B. Theroux and R.L. Wigley. 1977. Synoptic comparison of three sampling techniques for estimating abundance and distribution of selected magafauna: submersible vs. camera sled vs. otter traw1. Mar. Fish. Rev. 39(2): 11-19.

Venables, B.J. 1981. Aspects of the population biology of a Venezuelan beach amphipod, Talorchestia margaritae ( Talitridae), including estimates of biomass and daily production, and respiration rates. Crustaceana $41(3)$ : 271-285.

Verril1, A.E. 1871. On the food and habits of some of our marine fishes. Am. Natur. 5: 397-400.

Virnstein, R.W. 1977. The importance of predation by crabs and fish on benthic infauna in Chesapeake Bay. Ecology 58: 1199-1217.

Walsh, J.J. 1981. Shelf-sea ecosystems. In: A.R. Longhurst (ed.) The Analysis of Marine Ecosystems. Academic Press. pp. 159-196.

Wigley, R.L. 1968. Benthic invertebrates of the New England fishing banks. Bul1. Am. Litt. Soc. 5: 8-13.

Wildish, D.J. 1984. Secondary production of four sublittoral, softsediment amphipod populations in the Bay of Fundy. Can. J. Zool. 62: 1027-1033.

Wildish, D.J. and D. Peer. 1981. Methods for estimating secondary production in marine amphipoda. Can. J. Fish. Aquat. Sci. 38: $1019-1026$.

Wildish, D.J. and D. Peer. 1983. Tidal current speed and production of benthic macrofauna in the lower Bay of Fundy. Can. J. Fish. Aquat. Sc1. 40 (Supp1. 1): 309-321.

Zaret, T.M. 1980. Predation and Freshwater Communities. Yale University Press, New Haven, Conn. 
Appendix A. Ampelisca agassizi production (wet weight) at Station 13 from July 1981 to July 1982.

\begin{tabular}{|c|c|c|c|c|c|c|c|c|c|}
\hline Cohort & Month & $\begin{array}{l}\text { No. in } \\
\text { cohort } \\
\quad N\end{array}$ & $\begin{array}{l}\text { Mean } \\
\text { length } \\
\overline{\mathbf{L}}(\mathrm{mm})\end{array}$ & $\begin{array}{c}\text { Standard } \\
\text { deviation } \\
8_{L}\end{array}$ & $\begin{array}{l}\text { Mean } \\
\text { welght } \\
\bar{w}(\mathrm{mg})\end{array}$ & $\begin{array}{l}\text { Biomass } \\
N \bar{w}(m g)\end{array}$ & $\begin{array}{l}\text { Weight } \\
\text { increment } \\
\Delta \bar{w}(\mathrm{mg})\end{array}$ & $\begin{array}{l}\text { Mean } \\
\text { number } \\
\overline{\mathrm{N}}\end{array}$ & $\begin{array}{l}\text { Production } \\
\text { increment } \\
\overline{\mathrm{N}} \Delta \overline{\mathrm{w}}(\mathrm{mg})\end{array}$ \\
\hline $80 \mathrm{~A}$ & $\begin{array}{l}\text { Ju1 } \\
\text { Nov } \\
\text { Feb } \\
\text { May } \\
\text { Jul }\end{array}$ & $\begin{array}{r}154.2 \\
114.4 \\
164.6 \\
12.1 \\
31.1\end{array}$ & $\begin{array}{l}6.95 \\
7.19 \\
7.64 \\
9.28 \\
9.43\end{array}$ & $\begin{array}{l}0.70 \\
0.68 \\
0.34 \\
0.20 \\
0.49\end{array}$ & $\begin{array}{l}3.76 \\
4.11 \\
4.77 \\
5.91 \\
8.44\end{array}$ & $\begin{array}{r}579.8 \\
470.2 \\
785.1 \\
71.5 \\
262.5\end{array}$ & $\begin{array}{l}- \\
0.35 \\
0.66 \\
1.14 \\
2.53\end{array}$ & $\begin{array}{r}13 \overline{4} .3 \\
139.5 \\
88.4 \\
21.6\end{array}$ & $\begin{array}{r}- \\
47.0 \\
92.1 \\
100.7 \\
54.6\end{array}$ \\
\hline $80 \mathrm{~B}$ & $\begin{array}{l}\text { Jul } \\
\text { Nov } \\
\text { Feb } \\
\text { May } \\
\text { Jul }\end{array}$ & $\begin{array}{r}44.8 \\
77.5 \\
1760 \\
7.8 \\
27.8\end{array}$ & $\begin{array}{l}4.34 \\
6.21 \\
6.26 \\
7.49 \\
8.60\end{array}$ & $\begin{array}{l}0.60 \\
0.48 \\
1.10 \\
0.25 \\
0.18\end{array}$ & $\begin{array}{l}1.08 \\
2.83 \\
2.97 \\
4.51 \\
6.54\end{array}$ & $\begin{array}{r}48.4 \\
219.3 \\
522.7 \\
35.2 \\
181.8\end{array}$ & $\begin{array}{l}- \\
1.75 \\
0.14 \\
1.54 \\
2.03\end{array}$ & $\begin{array}{r}- \\
61.2 \\
126.8 \\
91.9 \\
17.8\end{array}$ & $\begin{array}{r}- \\
107.0 \\
17.7 \\
141.5 \\
36.1\end{array}$ \\
\hline 814 & $\begin{array}{l}\text { Nov } \\
\text { Feb } \\
\text { May } \\
\text { JuI }\end{array}$ & $\begin{array}{r}181.3 \\
298.6 \\
46.9 \\
278.4\end{array}$ & $\begin{array}{l}2.42 \\
3.52 \\
4.99 \\
6.35\end{array}$ & $\begin{array}{l}0.56 \\
0.80 \\
1.14 \\
0.81\end{array}$ & $\begin{array}{l}0.24 \\
0.66 \\
1.68 \\
2.99\end{array}$ & $\begin{array}{r}43.5 \\
197.1 \\
78.8 \\
832.4\end{array}$ & $\begin{array}{l}- \\
0.42 \\
1.02 \\
1.31\end{array}$ & $\begin{array}{l}24 \overline{0} .0 \\
172.8 \\
162.7\end{array}$ & $\begin{array}{l}- \\
100.8 \\
176.2 \\
231.1\end{array}$ \\
\hline $81 B$ & $\begin{array}{l}\text { Feb } \\
\text { May } \\
\text { Jul }\end{array}$ & $\begin{array}{r}215.9 \\
84.3 \\
238.8\end{array}$ & $\begin{array}{l}2.40 \\
2.91 \\
4.68\end{array}$ & $\begin{array}{l}0.32 \\
0.58 \\
0.67\end{array}$ & $\begin{array}{l}0.22 \\
0.38 \\
1.32\end{array}$ & $\begin{array}{r}47.5 \\
32.0 \\
315.2\end{array}$ & $\begin{array}{l}- \\
0.16 \\
0.94\end{array}$ & $\begin{array}{l}\overline{-} \\
150.1 \\
161.6\end{array}$ & $\begin{array}{r}-\overline{0} \\
151.9\end{array}$ \\
\hline $\begin{array}{l}\text { Total } \\
\text { Total } \\
\text { Mean } b \\
\text { Produc }\end{array}$ & $\begin{array}{l}\text { roduct } \\
\text { iomass: } \\
\text { omass: } \\
\text { ion/mea }\end{array}$ & In bioms & $\begin{array}{l}1.2 \\
4.7 \\
0.9\end{array}$ & $\begin{array}{llll}6 & \mathrm{~g} & 0.24 & \mathrm{n} \\
2 & \mathrm{~g} & 0.24 & \\
5 & \mathrm{~g} & 0.24 & \end{array}$ & $\begin{array}{l}\mathrm{m}^{-2} \mathrm{yr}^{-1} \\
\mathrm{~m}^{-2} \\
\mathrm{~m}^{-2}\end{array}$ & \multicolumn{4}{|c|}{$\begin{array}{rl}5.26 & \mathrm{~g} \mathrm{~m}^{-2} \mathrm{yr}^{-1} \\
19.68 & \mathrm{~g} \mathrm{~m}^{-2} \\
3.93 & \mathrm{~g} \mathrm{~m}^{-2} \\
1.34 \mathrm{~g} \mathrm{yr}^{-1}\end{array}$} \\
\hline
\end{tabular}


Appendix A. Ampelisca agassizi production (wet weight)

at Station 13 from July 1982 to July 1983.

\begin{tabular}{|c|c|c|c|c|c|c|c|c|c|}
\hline Cohort & Month & $\begin{array}{l}\text { No. in } \\
\text { cohort } \\
N\end{array}$ & $\begin{array}{c}\text { Mean } \\
\text { length } \\
\overline{\mathrm{L}}(\mathrm{mm})\end{array}$ & $\begin{array}{l}\text { Standard } \\
\text { deviation } \\
\text { sL }_{\text {L }}\end{array}$ & $\begin{array}{l}\text { Mean } \\
\text { weight } \\
\bar{w}(\mathrm{mg})\end{array}$ & $\begin{array}{l}\text { Biomass } \\
\sqrt{\mathrm{w}}(\mathrm{mg})\end{array}$ & $\begin{array}{l}\text { Weight } \\
\text { increment } \\
\Delta \overline{\mathbf{w}}(\mathrm{mg})\end{array}$ & $\begin{array}{l}\text { Mean } \\
\text { number } \\
\overline{\bar{N}}\end{array}$ & $\begin{array}{l}\text { Production } \\
\text { Increment } \\
\bar{N} \Delta \bar{w} \text { (mg) }\end{array}$ \\
\hline $80 \mathrm{~A}$ & Jul & 31.1 & 9.43 & 0.49 & 8.44 & 26.2 & - & - & - \\
\hline $80 \mathrm{~B}$ & $\mathrm{Jul}$ & 27.8 & 8.61 & 0.18 & 6.56 & 182.4 & - & - & - \\
\hline $81 \mathrm{~A}$ & $\begin{array}{l}\text { Jul } \\
\text { Nov } \\
\text { Feb }\end{array}$ & $\begin{array}{l}278.4 \\
190.0 \\
122.7\end{array}$ & $\begin{array}{l}6.35 \\
7.46 \\
7.94\end{array}$ & $\begin{array}{l}0.81 \\
0.43 \\
0.74\end{array}$ & $\begin{array}{l}2.99 \\
4.49 \\
5.37\end{array}$ & $\begin{array}{l}832.4 \\
404.1 \\
658.9\end{array}$ & $\begin{array}{l}- \\
1.50 \\
0.88\end{array}$ & $\begin{array}{l}184.2 \\
106.4\end{array}$ & $\begin{array}{r}276.3 \\
93.6\end{array}$ \\
\hline $81 B$ & $\begin{array}{l}\text { Jul } \\
\text { Nov } \\
\text { Feb } \\
\text { May } \\
\text { Jul }\end{array}$ & $\begin{array}{l}238.8 \\
199.9 \\
239.3 \\
148.1 \\
148.8\end{array}$ & $\begin{array}{l}4.68 \\
6.47 \\
6.94 \\
8.00 \\
8.12\end{array}$ & $\begin{array}{l}0.67 \\
0.47 \\
0.55 \\
0.78 \\
0.57\end{array}$ & $\begin{array}{l}1.32 \\
3.07 \\
3.72 \\
5.49 \\
5.66\end{array}$ & $\begin{array}{l}315.2 \\
613.7 \\
890.2 \\
813.1 \\
842.2\end{array}$ & $\begin{array}{l}- \\
1.75 \\
0.65 \\
1.77 \\
0.17\end{array}$ & $\begin{array}{r}- \\
219.4 \\
219.6 \\
193.7 \\
148.5\end{array}$ & $\begin{array}{r}- \\
383.9 \\
142.7 \\
342.8 \\
25.2\end{array}$ \\
\hline $82 \mathrm{~A}$ & $\begin{array}{l}\text { Nov } \\
\text { Feb } \\
\text { May } \\
\text { Jul }\end{array}$ & $\begin{array}{l}356.9 \\
574.1 \\
403.1 \\
115.0\end{array}$ & $\begin{array}{l}4.09 \\
5.11 \\
6.92 \\
6.95\end{array}$ & $\begin{array}{l}0.50 \\
0.63 \\
1.00 \\
0.32\end{array}$ & $\begin{array}{l}0.91 \\
1.66 \\
3.81 \\
3.70\end{array}$ & $\begin{array}{r}324.8 \\
953.0 \\
1535.8 \\
424.5\end{array}$ & $\begin{array}{l}- \\
0.75 \\
1.15 \\
0.11\end{array}$ & $\begin{array}{l}- \\
465.5 \\
488.6 \\
259.1\end{array}$ & $\begin{array}{c}- \\
349.1 \\
561.9 \\
-28.5\end{array}$ \\
\hline $82 B$ & $\begin{array}{l}\text { Nov } \\
\text { Feb } \\
\text { May } \\
\text { Jul }\end{array}$ & $\begin{array}{l}295.7 \\
544.2 \\
458.0 \\
298.5\end{array}$ & $\begin{array}{l}2.34 \\
2.55 \\
3.97 \\
5.11\end{array}$ & $\begin{array}{l}0.34 \\
0.44 \\
0.67 \\
0.68\end{array}$ & $\begin{array}{l}0.20 \\
0.26 \\
0.86 \\
1.67\end{array}$ & $\begin{array}{r}59.1 \\
141.5 \\
393.9 \\
498.5\end{array}$ & $\begin{array}{l}- \\
0.06 \\
0.60 \\
0.81\end{array}$ & $\begin{array}{c}- \\
420.0 \\
501.1 \\
378.3\end{array}$ & $\begin{array}{r}- \\
25.2 \\
300.7 \\
306.4\end{array}$ \\
\hline $\begin{array}{l}\text { Total } \\
\text { Total } \\
\text { Mean bi } \\
\text { Product }\end{array}$ & $\begin{array}{l}\text { omass: } \\
\text { Ion/mea }\end{array}$ & & $\begin{array}{l}2.7 \\
9.9 \\
1.9\end{array}$ & $\begin{array}{llll}8 & g & 0.24 & m \\
1 & g & 0.24 & m \\
8 & g & 0.24 & m\end{array}$ & $\begin{array}{l}-2 \\
-2 \\
y^{-1}\end{array}$ & \multicolumn{3}{|c|}{$\begin{array}{rl}11.58 & \mathrm{~g} \mathrm{~m}^{-2} \mathrm{yr}^{-1} \\
41.29 \mathrm{~g} \mathrm{~m}^{-2} & \\
8.26 \mathrm{~g} \mathrm{~m}^{-2} \\
1.40 \mathrm{~g} \mathrm{y}^{-1}\end{array}$} & \\
\hline
\end{tabular}


Appendix A. Unciola inermis production (wet weight) at Station 5-1 from July 1981 to July 1982.

\begin{tabular}{|c|c|c|c|c|c|c|c|c|c|}
\hline Cohort & Month & $\begin{array}{l}\text { No. in } \\
\text { cohort } \\
\text { N }\end{array}$ & $\begin{array}{c}\text { Mean } \\
\text { length } \\
\overline{\mathrm{L}}(\mathrm{mm})\end{array}$ & $\begin{array}{l}\text { Standard } \\
\text { deviation } \\
s_{\mathrm{L}}\end{array}$ & $\begin{array}{c}\text { Mean } \\
\text { weight } \\
\text { w(mg) }\end{array}$ & $\begin{array}{l}\text { Biomass } \\
\overline{N w}(\mathrm{mg})\end{array}$ & $\begin{array}{l}\text { Weight } \\
\text { Increment } \\
\Delta \bar{w}(\mathrm{mg})\end{array}$ & $\begin{array}{c}\text { Mean } \\
\text { number } \\
\overline{\mathrm{N}}\end{array}$ & $\begin{array}{l}\text { Production } \\
\text { increment } \\
\overline{\mathrm{N}} \Delta \overline{\mathrm{w}}(\mathrm{mg})\end{array}$ \\
\hline $80 \mathrm{~A}$ & Jul & 9.8 & 8.80 & 0.21 & 10.92 & 107.0 & - & - & - \\
\hline $80 B$ & $\begin{array}{l}\text { Jul } \\
\text { Nov }\end{array}$ & $\begin{array}{r}122.3 \\
13.8\end{array}$ & $\begin{array}{l}7.23 \\
9.59\end{array}$ & $\begin{array}{l}0.43 \\
0.31\end{array}$ & $\begin{array}{r}6.75 \\
13.53\end{array}$ & $\begin{array}{l}325.5 \\
186.7\end{array}$ & $\overline{6.78}$ & 68.1 & $46 \overline{1.7}$ \\
\hline $81 \mathrm{~A}$ & $\begin{array}{l}\text { Jul } \\
\text { Nov } \\
\text { Feb } \\
\text { May } \\
\text { Jul }\end{array}$ & $\begin{array}{r}230.6 \\
55.0 \\
8.4 \\
29.2 \\
51.6\end{array}$ & $\begin{array}{l}4.03 \\
7.07 \\
7.57 \\
9.29 \\
3.92\end{array}$ & $\begin{array}{l}0.78 \\
1.17 \\
0.37 \\
0.77 \\
0.75\end{array}$ & $\begin{array}{r}1.68 \\
6.66 \\
7.54 \\
12.64 \\
11.43\end{array}$ & $\begin{array}{r}387.4 \\
366.3 \\
63.3 \\
369.1 \\
589.8\end{array}$ & $\begin{array}{r}- \\
4.98 \\
0.88 \\
5.10 \\
-1.21\end{array}$ & $\begin{array}{r}- \\
142.8 \\
63.4 \\
18.8 \\
40.4\end{array}$ & $\begin{array}{r}711.1 \\
55.8 \\
95.9 \\
-48.9\end{array}$ \\
\hline $81 B$ & $\begin{array}{l}\text { Jul } \\
\text { Nov } \\
\text { Feb } \\
\text { May } \\
\text { Jul }\end{array}$ & $\begin{array}{r}265.2 \\
227.1 \\
226.9 \\
117.9 \\
59.8\end{array}$ & $\begin{array}{l}2.32 \\
4.48 \\
3.94 \\
7.19 \\
7.45\end{array}$ & $\begin{array}{l}0.53 \\
0.92 \\
0.66 \\
0.73 \\
0.42\end{array}$ & $\begin{array}{l}0.44 \\
2.21 \\
1.56 \\
6.74 \\
7.26\end{array}$ & $\begin{array}{l}116.7 \\
501.9 \\
354.0 \\
794.6 \\
434.1\end{array}$ & $\begin{array}{r}- \\
1.77 \\
-0.65 \\
5.18 \\
0.52\end{array}$ & $\begin{array}{r}246.2 \\
227.0 \\
172.4 \\
88.9\end{array}$ & $\begin{array}{r}- \\
435.8 \\
-147.6 \\
893.0 \\
46.2\end{array}$ \\
\hline $82 \mathrm{~A}$ & $\begin{array}{l}\text { May } \\
\text { Jul }\end{array}$ & $\begin{array}{l}49.7 \\
11.1\end{array}$ & $\begin{array}{l}2.88 \\
5.91\end{array}$ & $\begin{array}{l}0.59 \\
0.19\end{array}$ & $\begin{array}{l}0.74 \\
4.07\end{array}$ & $\begin{array}{l}36.8 \\
45.2\end{array}$ & $\overline{3.33}$ & $30 . \overline{4}$ & $10 \overline{-} .2$ \\
\hline $82 B$ & $\begin{array}{l}\text { May } \\
\text { Jul }\end{array}$ & $\begin{array}{l}335.3 \\
297.2\end{array}$ & $\begin{array}{l}1.49 \\
3.73\end{array}$ & $\begin{array}{l}0.18 \\
0.82\end{array}$ & $\begin{array}{l}0.14 \\
1.41\end{array}$ & $\begin{array}{r}46.9 \\
419.1\end{array}$ & $\overline{1.27}$ & $316^{-} 3$ & 401.7 \\
\hline $\begin{array}{l}\text { Total } \\
\text { Total } \\
\text { Mean b } \\
\text { Produc }\end{array}$ & $\begin{array}{l}\text { Omass: } \\
\text { Ion/mea }\end{array}$ & & $\begin{array}{l}3.0 \\
5.6 \\
1.1\end{array}$ & $\begin{array}{lll}1 & g & 0.24 \\
4 & g & 0.24 \\
3 & g & 0.24\end{array}$ & $\begin{array}{ll}\mathrm{m}^{-2} & \mathrm{yr}^{-1} \\
\mathrm{~m}^{-2} & \mathrm{yr}^{-1} \\
\mathrm{~m}^{-2} & \mathrm{yr}^{-1}\end{array}$ & \multicolumn{3}{|c|}{$\begin{array}{rl}12.52 & \mathrm{~g} \mathrm{~m}^{-2} \mathrm{yr}^{-1} \\
23.52 & \mathrm{~g} \mathrm{~m}^{-2} \\
4.70 \mathrm{~g} \mathrm{~m}^{-2} \\
2.66 \mathrm{~g} \mathrm{yr}^{-1}\end{array}$} & \\
\hline
\end{tabular}


Appendix A. Unciola Inermis production (wet weight)

at Station 5-1 from July 1982 to July 1983.

\begin{tabular}{|c|c|c|c|c|c|c|c|c|c|}
\hline Cohort & Month & $\begin{array}{l}\text { No. in } \\
\text { cohort } \\
\mathrm{N}\end{array}$ & $\begin{array}{c}\text { Mean } \\
\text { length } \\
\overline{\mathrm{L}}(\mathrm{mm})\end{array}$ & $\begin{array}{c}\text { Standard } \\
\text { deviation } \\
s_{L}\end{array}$ & $\begin{array}{c}\text { Mean } \\
\text { welght } \\
\text { w(mg) }\end{array}$ & $\begin{array}{l}\text { Blomass } \\
\bar{N} \bar{w}(\mathrm{mg})\end{array}$ & $\begin{array}{l}\text { Welght } \\
\text { increment } \\
\Delta \overline{\mathrm{w}}(\mathrm{mg})\end{array}$ & $\begin{array}{c}\text { Mean } \\
\text { number } \\
\overline{\bar{N}}\end{array}$ & $\begin{array}{l}\text { Production } \\
\text { Increment } \\
\bar{N} \Delta \bar{w}(\mathrm{mg})\end{array}$ \\
\hline $81 \mathrm{~A}$ & $\begin{array}{l}\text { Jul } \\
\text { Nov }\end{array}$ & $\begin{array}{r}51.6 \\
1.4\end{array}$ & $\begin{array}{r}8.92 \\
11.00\end{array}$ & $\begin{array}{l}0.75 \\
0.10\end{array}$ & $\begin{array}{l}11.43 \\
18.98\end{array}$ & $\begin{array}{r}589.8 \\
26.6\end{array}$ & 7.55 & 26.5 & 200.1 \\
\hline $81 B$ & $\begin{array}{l}\text { Jul } \\
\text { Nov } \\
\text { Feb } \\
\text { May }\end{array}$ & $\begin{array}{r}59.8 \\
12.9 \\
1.7 \\
6.0\end{array}$ & $\begin{array}{r}7.45 \\
8.89 \\
9.62 \\
11.00\end{array}$ & $\begin{array}{l}0.42 \\
0.51 \\
0.20 \\
0.40\end{array}$ & $\begin{array}{r}7.26 \\
11.26 \\
13.62 \\
19.02\end{array}$ & $\begin{array}{r}434.1 \\
145.3 \\
23.2 \\
114.1\end{array}$ & $\begin{array}{l}- \\
4.00 \\
2.36 \\
5.40\end{array}$ & $\begin{array}{r}- \\
36.4 \\
7.3 \\
3.9\end{array}$ & $\begin{array}{r}- \\
145.4 \\
17.2 \\
20.8\end{array}$ \\
\hline $82 \mathrm{~A}$ & $\begin{array}{l}\text { Jul } \\
\text { Nov } \\
\text { Feb } \\
\text { May } \\
\text { Jul }\end{array}$ & $\begin{array}{r}11.1 \\
2.4 \\
18.8 \\
18.5 \\
32.4\end{array}$ & $\begin{array}{l}5.91 \\
7.80 \\
7.81 \\
8.90 \\
9.07\end{array}$ & $\begin{array}{l}0.19 \\
0.10 \\
0.68 \\
0.28 \\
0.63\end{array}$ & $\begin{array}{r}4.07 \\
3.09 \\
3.23 \\
11.24 \\
11.86\end{array}$ & $\begin{array}{r}45.2 \\
19.4 \\
154.7 \\
207.9 \\
384.3\end{array}$ & $\begin{array}{l}- \\
4.02 \\
0.14 \\
3.01 \\
0.62\end{array}$ & $\begin{array}{r}- \\
6.8 \\
10.6 \\
13.7 \\
25.5\end{array}$ & $\begin{array}{r}- \\
27.1 \\
1.5 \\
56.3 \\
15.8\end{array}$ \\
\hline 82B & $\begin{array}{l}\text { Jul } \\
\text { Nov } \\
\text { Feb } \\
\text { May } \\
\text { Ju1 }\end{array}$ & $\begin{array}{r}297.2 \\
103.7 \\
83.7 \\
89.0 \\
76.2\end{array}$ & $\begin{array}{l}3.73 \\
5.38 \\
5.24 \\
7.45 \\
7.61\end{array}$ & $\begin{array}{l}0.82 \\
0.75 \\
0.91 \\
0.76 \\
0.40\end{array}$ & $\begin{array}{l}1.41 \\
3.34 \\
3.19 \\
7.36 \\
7.65\end{array}$ & $\begin{array}{l}419.1 \\
346.4 \\
267.0 \\
665.0 \\
582.9\end{array}$ & $\begin{array}{r}- \\
1.93 \\
-0.15 \\
4.17 \\
0.29\end{array}$ & $\begin{array}{r}- \\
200.5 \\
93.7 \\
86.4 \\
82.6\end{array}$ & $\begin{array}{r}- \\
386.9 \\
-14.1 \\
360.1 \\
24.0\end{array}$ \\
\hline $82 \mathrm{Cl}$ & Nov & 21.0 & 1.77 & 0.31 & 0.22 & 4.6 & - & - & - \\
\hline $83 \mathrm{~A}$ & $\begin{array}{l}\text { May } \\
\text { Jul }\end{array}$ & $\begin{array}{r}267.1 \\
65.7\end{array}$ & $\begin{array}{l}3.08 \\
6.45\end{array}$ & $\begin{array}{l}0.74 \\
0.44\end{array}$ & $\begin{array}{l}0.89 \\
5.09\end{array}$ & $\begin{array}{l}237.7 \\
334.4\end{array}$ & $\overline{4.20}$ & $\overline{-}$ & 698.9 \\
\hline
\end{tabular}


Appendix A. Unciola inermis production (continued)

\begin{tabular}{|c|c|c|c|c|c|c|c|c|c|c|}
\hline Cohort & Month & $\begin{array}{l}\text { No. In } \\
\text { cohort } \\
N\end{array}$ & $\begin{array}{c}\text { Mean } \\
\text { length } \\
\overline{\mathrm{L}}(\mathrm{mm})\end{array}$ & $\begin{array}{l}\text { St } \\
\text { de }\end{array}$ & $\begin{array}{l}\text { ndard } \\
\text { lation } \\
\text { gL }\end{array}$ & $\begin{array}{c}\text { Mean } \\
\text { weight } \\
\frac{w}{w}(\mathrm{mg})\end{array}$ & $\begin{array}{l}\text { Biomass } \\
\bar{N} \bar{w}(\mathrm{mg})\end{array}$ & $\begin{array}{l}\text { Welght } \\
\text { Increment } \\
\Delta \bar{w}(\mathrm{mg})\end{array}$ & $\begin{array}{c}\text { Mean } \\
\text { number } \\
\bar{N}\end{array}$ & $\begin{array}{l}\text { Production } \\
\text { Increment } \\
\overline{\mathrm{N}} \Delta \overline{\mathrm{w}}(\mathrm{mg})\end{array}$ \\
\hline $83 \mathrm{~B}$ & $\begin{array}{l}\text { May } \\
\text { Jul }\end{array}$ & $\begin{array}{l}261.1 \\
337.2\end{array}$ & $\begin{array}{l}1.50 \\
3.87\end{array}$ & & $\begin{array}{l}.17 \\
.93\end{array}$ & $\begin{array}{l}0.14 \\
1.58\end{array}$ & $\begin{array}{r}36.6 \\
532.8\end{array}$ & 1.44 & $299^{-} .2$ & $430^{-} .8$ \\
\hline $\begin{array}{l}\text { Total } \\
\text { Total } \\
\text { Mean bs } \\
\text { Product }\end{array}$ & $\begin{array}{l}\text { roduct: } \\
\text { lomass } \\
\text { omass: } \\
\text { lon/mes }\end{array}$ & $\begin{array}{l}\text { on: } \\
\text { n biomas }\end{array}$ & $\begin{array}{l}2 . \\
5 . \\
1 .\end{array}$ & $\begin{array}{ll}7 & 8 \\
7 & 8 \\
1 & 8\end{array}$ & $\begin{array}{l}0.24 \\
0.24 \\
0.24\end{array}$ & $\begin{array}{l}-2 \\
-2 \\
-2\end{array}$ & & $\begin{array}{l}g \mathrm{~m}^{-2} \mathrm{yr}^{-1} \\
\mathrm{~g} \mathrm{~m}^{-2} \\
\mathrm{~g} \mathrm{~m}^{-2} \\
\mathrm{yr}^{-1}\end{array}$ & & \\
\hline
\end{tabular}


Appendix A. Unciola inermis production (wet weight)

at Station 5-28 from July 1982 to July 1983.

\begin{tabular}{|c|c|c|c|c|c|c|c|c|c|}
\hline Cohort & Month & $\begin{array}{l}\text { No. In } \\
\text { cohort } \\
\text { N }\end{array}$ & $\begin{array}{c}\text { Mean } \\
\text { length } \\
\bar{L}(\mathrm{~mm})\end{array}$ & $\begin{array}{c}\text { Standard } \\
\text { deviation } \\
\text { 8L }\end{array}$ & $\begin{array}{l}\text { Mean } \\
\text { weight } \\
\bar{w}(\mathrm{mg})\end{array}$ & $\begin{array}{l}\text { Biomass } \\
\overline{N w}(\mathrm{mg})\end{array}$ & $\begin{array}{l}\text { Weight } \\
\text { increment } \\
\Delta \bar{w}(\mathrm{mg})\end{array}$ & $\begin{array}{c}\text { Mean } \\
\text { number } \\
\frac{\mathrm{N}}{\mathrm{N}}\end{array}$ & $\begin{array}{l}\text { Production } \\
\text { increment } \\
\overline{\mathrm{N}} \Delta \overline{\mathrm{w}}(\mathrm{mg})\end{array}$ \\
\hline 81A & $\begin{array}{l}\text { Jul } \\
\text { Nov } \\
\text { Feb } \\
\text { May } \\
\text { Jul }\end{array}$ & $\begin{array}{r}123.4 \\
3.4 \\
2.2 \\
1.3 \\
2.0\end{array}$ & $\begin{array}{r}9.13 \\
9.86 \\
10.27 \\
11.30 \\
12.25\end{array}$ & $\begin{array}{l}0.97 \\
0.3 \\
0.03 \\
- \\
-\end{array}$ & $\begin{array}{l}12.20 \\
14.49 \\
16.00 \\
20.28 \\
24.78\end{array}$ & $\begin{array}{r}1505.5 \\
49.3 \\
22.6 \\
26.4 \\
49.6\end{array}$ & $\begin{array}{l}- \\
2.29 \\
1.51 \\
4.28 \\
4.50\end{array}$ & $\begin{array}{r}- \\
63.4 \\
2.8 \\
1.8 \\
1.7\end{array}$ & $\begin{array}{r}- \\
145.2 \\
3.8 \\
7.7 \\
7.7\end{array}$ \\
\hline 81B & $\begin{array}{l}\text { Jul } \\
\text { Nov } \\
\text { Feb } \\
\text { May } \\
\text { Jul }\end{array}$ & $\begin{array}{r}47.5 \\
36.5 \\
4.2 \\
5.2 \\
2.0\end{array}$ & $\begin{array}{r}6.69 \\
8.30 \\
9.00 \\
10.06 \\
11.10\end{array}$ & $\begin{array}{l}0.44 \\
0.48 \\
0.1 \\
0.25 \\
-\end{array}$ & $\begin{array}{r}5.57 \\
9.49 \\
11.54 \\
15.22 \\
19.40\end{array}$ & $\begin{array}{r}264.6 \\
346.4 \\
49.5 \\
79.1 \\
38.8\end{array}$ & $\begin{array}{l}- \\
3.92 \\
2.05 \\
3.68 \\
4.18\end{array}$ & $\begin{array}{r}- \\
42.0 \\
20.4 \\
4.7 \\
3.6\end{array}$ & $\begin{array}{r}- \\
164.6 \\
41.8 \\
17.3 \\
15.0\end{array}$ \\
\hline $82 \mathrm{~A}$ & $\begin{array}{l}\text { Jul } \\
\text { Nov } \\
\text { Feb } \\
\text { May } \\
\text { Jul }\end{array}$ & $\begin{array}{r}72.0 \\
105.0 \\
51.2 \\
14.8 \\
28.1\end{array}$ & $\begin{array}{l}5.65 \\
6.68 \\
6.87 \\
7.90 \\
8.66\end{array}$ & $\begin{array}{l}0.24 \\
0.55 \\
0.77 \\
0.61 \\
0.55\end{array}$ & $\begin{array}{r}3.65 \\
5.58 \\
6.04 \\
8.44 \\
10.56\end{array}$ & $\begin{array}{l}262.8 \\
585.9 \\
309.2 \\
124.9 \\
296.7\end{array}$ & $\begin{array}{l}- \\
1.83 \\
0.46 \\
2.40 \\
2.12\end{array}$ & $\begin{array}{c}- \\
88.5 \\
78.1 \\
33.0 \\
21.4\end{array}$ & $\begin{array}{r}- \\
162.0 \\
35.9 \\
79.2 \\
45.4\end{array}$ \\
\hline $82 B$ & $\begin{array}{l}\text { Jul } \\
\text { Nov } \\
\text { Feb } \\
\text { May } \\
\text { Jul }\end{array}$ & $\begin{array}{r}550.6 \\
230.8 \\
144.3 \\
127.0 \\
49.2\end{array}$ & $\begin{array}{l}3.81 \\
5.00 \\
4.91 \\
6.12 \\
7.16\end{array}$ & $\begin{array}{l}0.67 \\
0.82 \\
0.76 \\
0.62 \\
0.65\end{array}$ & $\begin{array}{l}1.45 \\
2.82 \\
2.68 \\
4.52 \\
6.64\end{array}$ & $\begin{array}{l}798.4 \\
650.9 \\
386.7 \\
574.0 \\
326.7\end{array}$ & $\begin{array}{r}- \\
1.37 \\
-0.14 \\
1.84 \\
2.12\end{array}$ & $\begin{array}{r}- \\
390.7 \\
187.1 \\
135.6 \\
88.1\end{array}$ & $\begin{array}{r}- \\
535.3 \\
-26.3 \\
249.5 \\
186.8\end{array}$ \\
\hline 83A & $\begin{array}{l}\text { Feb } \\
\text { May } \\
\text { Jul }\end{array}$ & $\begin{aligned} 4.34 \\
61.6 \\
180.8\end{aligned}$ & $\begin{array}{l}2.15 \\
3.02 \\
4.38\end{array}$ & $\begin{array}{l}0.32 \\
0.58 \\
0.54\end{array}$ & $\begin{array}{l}0.34 \\
0.82 \\
1.99\end{array}$ & $\begin{array}{r}1.5 \\
50.5 \\
359.8\end{array}$ & $\begin{array}{l}- \\
0.48 \\
1.17\end{array}$ & $\begin{array}{r}- \\
33.0 \\
121.2\end{array}$ & $\begin{array}{r}- \\
15.8 \\
141.8\end{array}$ \\
\hline
\end{tabular}


Appendix A. Unciola inermis production (continued)

\begin{tabular}{|c|c|c|c|c|c|c|c|c|c|}
\hline Cohort & Month & $\begin{array}{l}\text { No. In } \\
\text { cohort } \\
N\end{array}$ & $\begin{array}{c}\text { Mean } \\
\text { length } \\
\overline{\mathrm{L}}(\mathrm{mm})\end{array}$ & $\begin{array}{c}\text { Standard } \\
\text { deviation } \\
{ }^{{ }^{L}}\end{array}$ & $\begin{array}{c}\text { Mean } \\
\text { welght } \\
\text { w(mg) }\end{array}$ & $\begin{array}{l}\text { B1omas8 } \\
\overline{N w}(m g)\end{array}$ & $\begin{array}{l}\text { Welght } \\
\text { increment } \\
\Delta \bar{w}(\mathrm{mg})\end{array}$ & $\begin{array}{l}\text { Mean } \\
\text { number } \\
\frac{N}{n}\end{array}$ & $\begin{array}{l}\text { Production } \\
\text { Increment } \\
\bar{N} \Delta \bar{w}(\mathrm{mg})\end{array}$ \\
\hline $83 B$ & $\begin{array}{l}\text { May } \\
\text { Jul }\end{array}$ & $\begin{array}{r}189.7 \\
38.0\end{array}$ & $\begin{array}{l}1.52 \\
3.16\end{array}$ & $\begin{array}{l}0.18 \\
0.22\end{array}$ & $\begin{array}{l}0.14 \\
0.87\end{array}$ & $\begin{array}{l}26.6 \\
33.1\end{array}$ & $\overline{0.73}$ & 113.8 & 83.1 \\
\hline $83 c$ & Jul & 121.2 & 2.03 & 0.29 & 0.30 & 36.4 & - & - & - \\
\hline $\begin{array}{l}\text { Total p } \\
\text { Total b } \\
\text { Mean b1 } \\
\text { Product }\end{array}$ & $\begin{array}{l}\text { roducti } \\
\text { Lomass: } \\
\text { omass: } \\
\text { Ion/mea }\end{array}$ & $\begin{array}{l}\text { on: } \\
\text { n bioma }\end{array}$ & $\begin{array}{l}1 . \\
7 . \\
1 .\end{array}$ & $\begin{array}{llll}1 & 8 & 0.24 \\
5 & 8 & 0.24 \\
5 & g & 0.24\end{array}$ & $\begin{array}{l}-2 \\
a-2 \\
-2\end{array}$ & & $\begin{array}{l}\mathrm{m}^{-2} \mathrm{yr}^{-1} \\
\mathrm{~m}^{-2} \\
\mathrm{~m}^{-2} \\
\mathrm{r}^{-1}\end{array}$ & & \\
\hline
\end{tabular}


Append1x A. Ericthonius fasciatus production (wet weight) at Station 5-1 from July 1981 to July 1982.

\begin{tabular}{|c|c|c|c|c|c|c|c|c|c|}
\hline Cohort & Month & $\begin{array}{l}\text { No. in } \\
\text { cohort } \\
N\end{array}$ & $\begin{array}{c}\text { Mean } \\
\text { length } \\
\overline{\mathrm{L}}(\mathrm{mm})\end{array}$ & $\begin{array}{c}\text { Standard } \\
\text { deviation } \\
{ }^{8_{L}}\end{array}$ & $\begin{array}{c}\text { Mean } \\
\text { welght } \\
\bar{w}(\mathrm{mg})\end{array}$ & $\begin{array}{l}\text { Biomass } \\
\overline{N w}(\mathrm{mg})\end{array}$ & $\begin{array}{l}\text { We1ght } \\
\text { increment } \\
\Delta \bar{w}(\mathrm{mg})\end{array}$ & $\begin{array}{c}\text { Mean } \\
\text { number } \\
\overline{\mathrm{N}}\end{array}$ & $\begin{array}{l}\text { Production } \\
\text { Increment } \\
\overline{\mathrm{N}} \Delta \overline{\mathrm{w}}(\mathrm{mg})\end{array}$ \\
\hline F80 & Jul & 27.8 & 5.87 & 0.70 & 2.08 & 57.3 & - & - & - \\
\hline S81A & $\begin{array}{l}\text { Jul } \\
\text { Nov }\end{array}$ & $\begin{array}{r}316.2 \\
7.7\end{array}$ & $\begin{array}{l}3.77 \\
7.11\end{array}$ & $\begin{array}{l}0.73 \\
0.50\end{array}$ & $\begin{array}{l}0.72 \\
3.28\end{array}$ & $\begin{array}{r}227.7 \\
25.3\end{array}$ & 2.56 & 162.0 & $414^{-} .7$ \\
\hline S81B & $\begin{array}{l}\text { Jul } \\
\text { Nov }\end{array}$ & $\begin{array}{l}471.3 \\
102.9\end{array}$ & $\begin{array}{l}2.30 \\
5.36\end{array}$ & $\begin{array}{l}0.38 \\
0.54\end{array}$ & $\begin{array}{l}0.21 \\
1.64\end{array}$ & $\begin{array}{r}99.0 \\
168.8\end{array}$ & 1.43 & 287.1 & 410.6 \\
\hline F81A & $\begin{array}{l}\text { Nov } \\
\text { Feb } \\
\text { May } \\
\text { Jul }\end{array}$ & $\begin{array}{r}117.8 \\
1.0 \\
282.3 \\
33.7\end{array}$ & $\begin{array}{l}2.59 \\
3.40 \\
6.05 \\
7.59\end{array}$ & $\begin{array}{l}0.66 \\
- \\
0.82 \\
0.48\end{array}$ & $\begin{array}{l}0.30 \\
0.52 \\
2.25 \\
3.85\end{array}$ & $\begin{array}{r}35.3 \\
0.5 \\
635.2 \\
129.7\end{array}$ & $\begin{array}{l}- \\
0.22 \\
1.73 \\
1.60\end{array}$ & $\begin{array}{c}- \\
59.4 \\
141.6 \\
158.0\end{array}$ & $\begin{array}{c}- \\
13.1 \\
245.0 \\
252.8\end{array}$ \\
\hline F81B & $\begin{array}{l}\text { Nov } \\
\text { Feb } \\
\text { May } \\
\text { Jul }\end{array}$ & $\begin{array}{r}115.0 \\
1.0 \\
103.0 \\
69.5\end{array}$ & $\begin{array}{l}1.56 \\
1.60 \\
5.00 \\
5.88\end{array}$ & $\begin{array}{l}0.20 \\
- \\
1.00 \\
0.48\end{array}$ & $\begin{array}{l}0.08 \\
0.08 \\
1.46 \\
2.06\end{array}$ & $\begin{array}{r}9.2 \\
0.2 \\
150.4 \\
143.2\end{array}$ & $\begin{array}{c}- \\
- \\
1.38 \\
0.60\end{array}$ & $\begin{array}{r}- \\
58.5 \\
52.5 \\
86.3\end{array}$ & $\begin{array}{c}- \\
- \\
72.5 \\
51.8\end{array}$ \\
\hline S82A & $\begin{array}{l}\text { May } \\
\text { Jul }\end{array}$ & $\begin{array}{l}202.2 \\
760.5\end{array}$ & $\begin{array}{l}1.42 \\
3.90\end{array}$ & $\begin{array}{l}0.15 \\
0.70\end{array}$ & $\begin{array}{l}0.06 \\
0.78\end{array}$ & $\begin{array}{r}12.1 \\
593.2\end{array}$ & 0.72 & 481.4 & $346^{-}$ \\
\hline S82B & Jul & 403.9 & 1.96 & 0.47 & 0.15 & 60.6 & - & - & - \\
\hline $\begin{array}{l}\text { Total } \\
\text { Total b } \\
\text { Mean bi } \\
\text { Product }\end{array}$ & $\begin{array}{l}\text { roduct1 } \\
\text { Lomass: } \\
\text { omass: } \\
\text { Ion/mea }\end{array}$ & n bloma & $\begin{array}{l}1 . \\
2 . \\
0 .\end{array}$ & $\begin{array}{lll}1 & \mathrm{~g} & 0.24 \\
5 & \mathrm{~g} & 0.24 \\
7 & \mathrm{~g} & 0.24\end{array}$ & $\begin{array}{l}-2 \\
-2 \\
-2\end{array}$ & & $\begin{array}{l}\mathrm{g} \mathrm{m}^{-2} \mathrm{yr}^{-1} \\
\mathrm{~g} \mathrm{~m}^{-2} \\
\mathrm{~g} \mathrm{~m}^{-2} \\
\mathrm{yr}^{-1}\end{array}$ & & \\
\hline
\end{tabular}


Appendix A. Ericthonius fasciatus production (wet weight) at station 5-1 from July 1982 to July 1983.

\begin{tabular}{|c|c|c|c|c|c|c|c|c|c|}
\hline Cohort & Month & $\begin{array}{l}\text { No. in } \\
\text { cohort } \\
N\end{array}$ & $\begin{array}{c}\text { Mean } \\
\text { length } \\
\overline{\mathrm{L}}(\mathrm{mm})\end{array}$ & $\begin{array}{c}\text { Standard } \\
\text { deviation } \\
\mathbf{8}_{\mathrm{L}}\end{array}$ & $\begin{array}{c}\text { Mean } \\
\text { we1ght } \\
\text { w(mg) }\end{array}$ & $\begin{array}{l}\text { Biomass } \\
N \bar{w}(\mathrm{mg})\end{array}$ & $\begin{array}{l}\text { We1ght } \\
\text { Increment } \\
\Delta \bar{w}(\mathbf{m g})\end{array}$ & $\begin{array}{l}\text { Mean } \\
\text { number } \\
\bar{N}\end{array}$ & $\begin{array}{l}\text { Production } \\
\text { Increment } \\
\bar{N} \Delta \bar{w}(m g)\end{array}$ \\
\hline F81A & Jul & 33.7 & 7.59 & 0.48 & 3.85 & 129.7 & - & - & - \\
\hline F81B & Jul & 69.5 & 5.88 & 0.48 & 2.06 & 143.2 & - & - & - \\
\hline S82A & Jul & 760.5 & 3.90 & 0.70 & 0.78 & 593.2 & - & - & - \\
\hline S82B & $\begin{array}{l}\text { Jul } \\
\text { Nov }\end{array}$ & $\begin{array}{l}403.9 \\
181.1\end{array}$ & $\begin{array}{l}1.96 \\
6.05\end{array}$ & $\begin{array}{l}0.47 \\
0.48\end{array}$ & $\begin{array}{l}0.15 \\
2.21\end{array}$ & $\begin{array}{r}60.6 \\
400.2\end{array}$ & $\overline{2.06}$ & 292.5 & 602.6 \\
\hline F82A & $\begin{array}{l}\text { Nov } \\
\text { Feb } \\
\text { May } \\
\text { Jul }\end{array}$ & $\begin{array}{r}513.1 \\
1077.6 \\
18.7 \\
12.8\end{array}$ & $\begin{array}{l}2.90 \\
4.84 \\
7.26 \\
9.15\end{array}$ & $\begin{array}{l}0.80 \\
0.69 \\
0.75 \\
0.25\end{array}$ & $\begin{array}{l}0.40 \\
1.30 \\
3.49 \\
6.09\end{array}$ & $\begin{array}{r}205.2 \\
1400.9 \\
65.3 \\
78.0\end{array}$ & $\begin{array}{l}- \\
0.90 \\
2.19 \\
2.60\end{array}$ & $\begin{array}{r}795 . \overline{4} \\
548.2 \\
15.8\end{array}$ & $\begin{array}{r}715.9 \\
1200.6 \\
41.1\end{array}$ \\
\hline F82B & $\begin{array}{l}\text { Nov } \\
\text { Feb } \\
\text { May } \\
\text { Jul }\end{array}$ & $\begin{array}{r}524.4 \\
612.2 \\
50.4 \\
149.2\end{array}$ & $\begin{array}{l}1.74 \\
3.42 \\
4.80 \\
7.01\end{array}$ & $\begin{array}{l}0.34 \\
0.89 \\
1.00 \\
0.52\end{array}$ & $\begin{array}{l}0.11 \\
0.60 \\
1.33 \\
3.17\end{array}$ & $\begin{array}{r}57.7 \\
367.3 \\
67.0 \\
473.0\end{array}$ & $\begin{array}{l}- \\
0.49 \\
0.73 \\
1.84\end{array}$ & $\begin{array}{r}- \\
568.3 \\
331.3 \\
99.6\end{array}$ & $\begin{array}{r}- \\
278.5 \\
241.8 \\
183.3\end{array}$ \\
\hline S83A & $\begin{array}{l}\text { Feb } \\
\text { May } \\
\text { Jul }\end{array}$ & $\begin{array}{l}436.9 \\
547.9 \\
570.8\end{array}$ & $\begin{array}{l}1.58 \\
2.28 \\
4.65\end{array}$ & $\begin{array}{l}0.30 \\
0.40 \\
1.06\end{array}$ & $\begin{array}{l}0.08 \\
0.20 \\
1.24\end{array}$ & $\begin{array}{r}35.0 \\
109.6 \\
707.8\end{array}$ & $\begin{array}{l}- \\
0.12 \\
1.04\end{array}$ & $\begin{array}{c}- \\
492.4 \\
559.4\end{array}$ & $\begin{array}{r}- \\
59.1 \\
581.8\end{array}$ \\
\hline
\end{tabular}


Appendix A. Ericthonius fasciatus production (continued)

\begin{tabular}{|c|c|c|c|c|c|c|c|c|c|}
\hline Cohort & Month & $\begin{array}{l}\text { No. in } \\
\text { cohort } \\
\text { N }\end{array}$ & $\begin{array}{l}\text { Mean } \\
\text { length } \\
\overline{\mathrm{L}}(\mathrm{mm})\end{array}$ & $\begin{array}{c}\text { Standard } \\
\text { deviation } \\
\mathrm{S}_{\mathrm{L}}\end{array}$ & $\begin{array}{l}\text { Mean } \\
\text { weight } \\
\frac{w}{w}(\mathrm{mg})\end{array}$ & $\begin{array}{l}\text { Blomass } \\
\bar{N} \text { (mg) }\end{array}$ & $\begin{array}{l}\text { Weight } \\
\text { increment } \\
\Delta \bar{w}(\mathrm{mg})\end{array}$ & $\begin{array}{l}\text { Mean } \\
\text { number } \\
\overline{\mathbf{N}}\end{array}$ & $\begin{array}{l}\text { Production } \\
\text { increment } \\
\overline{\mathrm{N}} \Delta \overline{\mathrm{w}}(\mathrm{mg})\end{array}$ \\
\hline S83B & $\begin{array}{l}\text { May } \\
\text { Jul }\end{array}$ & $\begin{array}{l}439.0 \\
117.0\end{array}$ & $\begin{array}{l}1.63 \\
1.85\end{array}$ & $\begin{array}{l}0.19 \\
0.40\end{array}$ & $\begin{array}{l}0.09 \\
0.13\end{array}$ & $\begin{array}{l}39.5 \\
15.2\end{array}$ & 0.04 & 278.0 & 11.2 \\
\hline $\begin{array}{l}\text { Total } \\
\text { Total } \\
\text { Mean b } \\
\text { Produc }\end{array}$ & $\begin{array}{l}\text { roduct1 } \\
\text { lomass: } \\
\text { omass: } \\
\text { lon/mea }\end{array}$ & $\begin{array}{l}\text { on: } \\
\text { n blomas }\end{array}$ & $\begin{array}{l}3.9 \\
4.4 \\
0.9\end{array}$ & $\begin{array}{lll}2 & \mathrm{~g} & 0.24 \\
5 & \mathrm{~g} & 0.24 \\
9 & \mathrm{~g} & 0.24\end{array}$ & $\begin{array}{l}m^{-2} y^{-1} \\
m^{-2} \\
m^{-2}\end{array}$ & $\begin{array}{r}16 \\
20 \\
4 \\
3\end{array}$ & $\begin{array}{l}\mathrm{g} \mathrm{m}^{-2} \mathrm{yr}^{-1} \\
\mathrm{~g} \mathrm{~m}^{-2} \\
\mathrm{~g} \mathrm{\textrm {m } ^ { - 2 }} \\
\mathrm{yr}^{-1}\end{array}$ & & \\
\hline
\end{tabular}


Appendix A. Ericthonius fasciatus production (wet weight) at Station 5-28 from July 1982 to July 1983.

\begin{tabular}{|c|c|c|c|c|c|c|c|c|c|}
\hline Cohort & Month & $\begin{array}{l}\text { No. in } \\
\text { cohort } \\
\quad \mathrm{N}\end{array}$ & $\begin{array}{l}\text { Mean } \\
\text { length } \\
\overline{\mathrm{L}}(\mathrm{mm})\end{array}$ & $\begin{array}{c}\text { Standard } \\
\text { deviation } \\
\mathrm{S}_{\mathrm{L}}\end{array}$ & $\begin{array}{c}\text { Mean } \\
\text { welght } \\
\bar{w}(\mathrm{mg})\end{array}$ & $\begin{array}{l}\text { Biomass } \\
\overline{N w}(\mathrm{mg})\end{array}$ & $\begin{array}{l}\text { Weight } \\
\text { increment } \\
\overline{\Delta \mathrm{w}(\mathrm{mg})}\end{array}$ & $\begin{array}{l}\text { Mean } \\
\text { number } \\
\overline{\mathrm{N}}\end{array}$ & $\begin{array}{l}\text { Production } \\
\text { Increment } \\
\overline{\mathrm{N}} \Delta \overline{\mathrm{w}}(\mathrm{mg})\end{array}$ \\
\hline F81A & $\mathrm{Jul}$ & 280.2 & 5.47 & 1.1 & 1.83 & 512.8 & - & - & - \\
\hline F81B & $\mathbf{J u 1}$ & 133.7 & 3.88 & 1.1 & 0.83 & 111.0 & - & - & - \\
\hline F82A & $\begin{array}{l}\text { Jul } \\
\text { Nov }\end{array}$ & $\begin{array}{l}100.9 \\
486.1\end{array}$ & $\begin{array}{l}1.89 \\
5.87\end{array}$ & $\begin{array}{l}0.40 \\
0.96\end{array}$ & $\begin{array}{l}0.13 \\
2.21\end{array}$ & $\begin{array}{r}13.1 \\
1074.3\end{array}$ & 2.08 & 293.5 & $610^{-} .5$ \\
\hline S82B & $\begin{array}{l}\text { Jul } \\
\text { Nov } \\
\text { Feb } \\
\text { May } \\
\text { Jul }\end{array}$ & $\begin{array}{r}320.5 \\
640.2 \\
1.1 \\
30.8 \\
17.0\end{array}$ & $\begin{array}{l}1.44 \\
4.94 \\
5.57 \\
7.14 \\
8.74\end{array}$ & $\begin{array}{c}0.10 \\
0.55 \\
- \\
0.38 \\
0.23\end{array}$ & $\begin{array}{l}0.06 \\
1.35 \\
1.78 \\
3.30 \\
5.43\end{array}$ & $\begin{array}{r}19.2 \\
837.3 \\
2.0 \\
101.6 \\
92.3\end{array}$ & $\begin{array}{l}- \\
1.29 \\
0.43 \\
1.52 \\
2.13\end{array}$ & $\begin{array}{r}- \\
480.4 \\
320.6 \\
15.9 \\
23.9\end{array}$ & $\begin{array}{r}- \\
619.7 \\
137.9 \\
24.2 \\
50.9\end{array}$ \\
\hline F82A & $\begin{array}{l}\text { Nov } \\
\text { Feb } \\
\text { May } \\
\text { Ju1 }\end{array}$ & $\begin{array}{r}1739.8 \\
1.1 \\
21.8 \\
209.4\end{array}$ & $\begin{array}{l}2.53 \\
4.12 \\
6.06 \\
6.11\end{array}$ & $\begin{array}{c}0.60 \\
- \\
0.39 \\
0.74\end{array}$ & $\begin{array}{l}0.28 \\
0.84 \\
2.21 \\
2.29\end{array}$ & $\begin{array}{r}487.1 \\
0.9 \\
48.2 \\
479.5\end{array}$ & $\begin{array}{l}- \\
0.56 \\
1.37 \\
0.08\end{array}$ & $\begin{array}{r}- \\
870.4 \\
11.4 \\
115.6\end{array}$ & $\begin{array}{r}- \\
487.4 \\
15.6 \\
9.2\end{array}$ \\
\hline F82B & $\begin{array}{l}\text { Nov } \\
\text { Feb } \\
\text { May } \\
\text { Jul }\end{array}$ & $\begin{array}{r}1436.1 \\
1.1 \\
84.3 \\
156.9\end{array}$ & $\begin{array}{l}1.48 \\
3.32 \\
3.99 \\
4.58\end{array}$ & $\begin{array}{l}0.16 \\
- \\
0.72 \\
0.46\end{array}$ & $\begin{array}{l}0.07 \\
0.49 \\
0.82 \\
1.11\end{array}$ & $\begin{array}{r}100.5 \\
0.5 \\
69.1 \\
174.2\end{array}$ & $\begin{array}{c}- \\
0.42 \\
0.33 \\
0.29\end{array}$ & $\begin{array}{r}- \\
718.6 \\
42.7 \\
120.6\end{array}$ & $\begin{array}{r}- \\
301.8 \\
12.8 \\
35.0\end{array}$ \\
\hline S83A & $\begin{array}{l}\text { Feb } \\
\text { May } \\
\text { Jul }\end{array}$ & $\begin{array}{r}1.1 \\
178.7 \\
187.8\end{array}$ & $\begin{array}{l}1.16 \\
1.40 \\
2.84\end{array}$ & $\begin{array}{l}- \\
0.11 \\
0.51\end{array}$ & $\begin{array}{l}0.04 \\
0.06 \\
0.35\end{array}$ & $\begin{array}{c}- \\
10.7 \\
65.7\end{array}$ & $\begin{array}{l}- \\
0.02 \\
0.29\end{array}$ & $\begin{array}{r}- \\
89.9 \\
183.2\end{array}$ & $\begin{array}{r}- \\
1.8 \\
53.1\end{array}$ \\
\hline
\end{tabular}


Appendix A. Ericthonius fasciatus production (continued)

\begin{tabular}{|c|c|c|c|c|c|c|c|c|c|c|}
\hline Cohort & Month & $\begin{array}{l}\text { No. in } \\
\text { cohort } \\
N\end{array}$ & $\begin{array}{l}\text { Mean } \\
\text { length } \\
\bar{L}(\mathrm{~mm})\end{array}$ & \multicolumn{2}{|c|}{$\begin{array}{c}\text { Standard } \\
\text { deviation } \\
\mathrm{S}_{\mathrm{L}}\end{array}$} & $\begin{array}{l}\text { Mean } \\
\text { welght } \\
\text { w(mg) }\end{array}$ & $\begin{array}{l}\text { Biomass } \\
\overline{N \bar{w}}(\mathrm{mg})\end{array}$ & $\begin{array}{l}\text { Weight } \\
\text { increment } \\
\Delta \bar{w}(\mathrm{mg})\end{array}$ & $\begin{array}{l}\text { Mean } \\
\text { number } \\
\bar{N}\end{array}$ & $\begin{array}{l}\text { Production } \\
\text { increment } \\
\overline{\mathrm{N}} \Delta \overline{\mathrm{w}}(\mathrm{mg})\end{array}$ \\
\hline S83B & Jul & 130.8 & 1.43 & & 0.12 & 0.06 & 7.8 & - & - & - \\
\hline $\begin{array}{l}\text { Total } \\
\text { Total } \\
\text { Mean b: } \\
\text { Produc }\end{array}$ & $\begin{array}{l}\text { roduct: } \\
\text { Lomass: } \\
\text { omass: } \\
\text { lon/mea }\end{array}$ & n bioma & $\begin{array}{l}2.3 \\
4.2 \\
0.8\end{array}$ & $\begin{array}{ll}6 & g \\
1 & g \\
4 & g\end{array}$ & $\begin{array}{l}0.24 \\
0.24 \\
0.24\end{array}$ & $\begin{array}{l}m^{-2} \text { yr } r^{-1} \\
m^{-2} \\
m^{-2}\end{array}$ & & $\begin{array}{l}g \mathrm{~m}^{-2} \mathrm{yr}-1 \\
\mathrm{~g} \mathrm{~m}^{-2} \\
\mathrm{~g} \mathrm{~m} \mathrm{~m}^{-2} \\
\mathrm{yr} \mathrm{r}^{-1}\end{array}$ & & \\
\hline
\end{tabular}


APPENDIX B. Yellowta11 Flounder stomach Contents Data - station 5

\begin{tabular}{|c|c|c|c|c|c|c|c|c|}
\hline $\begin{array}{l}\text { CLASS } \\
\text { Order } \\
\quad \text { Spectes }\end{array}$ & $\begin{array}{r}\text { August } \\
\% \text { numbers }\end{array}$ & $\begin{array}{l}1982 \\
\% \text { we1ght }\end{array}$ & $\begin{array}{l}\text { Oct., Dec } \\
\text { \% numbers }\end{array}$ & $\begin{array}{l}1982 \\
\% \text { welght }\end{array}$ & $\begin{array}{l}\text { Feb.-Ma } \\
\text { \% numbers }\end{array}$ & $\begin{array}{l}\text { ch } 1983 \\
\text { \% weight }\end{array}$ & $\begin{array}{r}\text { May } \\
\text { \% numbers }\end{array}$ & $\begin{array}{l}1983 \\
\text { \% welght }\end{array}$ \\
\hline \multicolumn{9}{|l|}{ POLYCHAETA } \\
\hline Ampharete arctica & 1.55 & 3.11 & 0.08 & 0.27 & - & - & - & - \\
\hline Arabella вp. A (R) & - & - & - & - & - & - & 0.05 & 0.72 \\
\hline Notomas tus latericeus & - & - & 0.02 & 0.02 & 0.04 & 0.05 & - & - \\
\hline Caullerlella n. sp. B & - & - & - & - & 0.04 & $<0.01$ & - & - \\
\hline Tharyx annulosus & - & - & - & - & 0.07 & 0.01 & - & - \\
\hline Pherusa cf. falcata & - & - & 0.02 & 0.05 & - & - & - & - \\
\hline Glycera capitata & - & - & - & - & - & - & 0.09 & 0.25 \\
\hline Gonlade 1 la gracilis & - & - & - & - & - & - & 0.09 & 0.03 \\
\hline Lumbrinerides acuta & - & - & - & - & 0.04 & 0.03 & 0.42 & 0.21 \\
\hline Lumbrinerides fragilis & 0.11 & 24.19 & - & - & - & - & 0.28 & 33.51 \\
\hline Clymenura polaris & 0.11 & 0.24 & 0.38 & 2.31 & 0.11 & 0.22 & 0.37 & 1.81 \\
\hline Euclymene sp. A & 0.23 & 0.20 & - & $<0.01$ & 0.14 & 0.08 & 1.48 & 0.72 \\
\hline Aglaophamus circinata & - & 1.58 & 0.06 & 0.02 & 0.07 & 1.16 & 0.09 & 3.10 \\
\hline Ophelina acuminata & 0.11 & 0.35 & 0.02 & 0.54 & - & - & - & - \\
\hline Myriochele oculata (R) & - & - & 0.02 & $<0.01$ & - & - & - & - \\
\hline Aricidea catherinae & 0.34 & 0.02 & 0.04 & $<0.01$ & - & - & - & - \\
\hline Ar1c1dea $\frac{\text { cerrut1 }}{\text { cent }}$ & 0.06 & 0.00 & 0.02 & $<0.01$ & - & - & 0.23 & 0.01 \\
\hline Phyllodoce mucosa & 0.06 & 0.03 & 0.04 & 0.04 & 0.18 & 0.15 & - & - \\
\hline Polygordius 8p. A & - & - & - & - & 0.07 & 0.01 & - & - \\
\hline Chone duner 1 & 0.74 & 0.74 & 0.60 & 1.93 & 0.14 & 0.08 & 0.19 & 0.10 \\
\hline Chone infundibuliformis & 3.09 & 32.19 & 0.19 & 0.20 & 0.07 & 0.25 & 3.85 & 16.44 \\
\hline Megalomma bioculata (R) & - & - & 0.02 & 0.20 & - & - & - & - \\
\hline Scalibregma Inflatum & 0.06 & 0.91 & - & - & 0.18 & 1.35 & 0.23 & 0.64 \\
\hline Pholoe minuta (R) & - & - & - & - & 0.04 & $<0.01$ & - & - \\
\hline Sthenela1s l1micola (R) & - & - & - & - & 0.04 & 2.07 & 0.05 & 0.70 \\
\hline$\frac{\text { Splophanes }}{\text { bombyx }}$ & - & - & - & - & 0.22 & 0.04 & 0.05 & - \\
\hline Polydora concharum. & - & - & - & - & - & 0.03 & - & - \\
\hline Exogone hebes & - & - & - & - & - & - & 0.05 & $<0.01$ \\
\hline Exogone verugera & - & - & 0.04 & $<0.01$ & 0.07 & 0.01 & 0.09 & $<0.01$ \\
\hline Parapionosyllis longlcirrata & - & - & - & - & 0.04 & $<0.01$ & - & - \\
\hline Polycirrus sp. D (R) & - & - & - & - & 0.04 & - & - & - \\
\hline
\end{tabular}


APPENDIX B - Station 5 (continued)

\begin{tabular}{|c|c|c|c|c|c|c|c|c|}
\hline $\begin{array}{l}\text { CluASS } \\
\text { Order } \\
\quad \text { Specles }\end{array}$ & $\begin{array}{r}\text { August } \\
\% \text { numbers }\end{array}$ & $\begin{array}{l}1982 \\
\% \text { weight }\end{array}$ & $\begin{array}{l}\text { oct., De } \\
\text { \% numbers }\end{array}$ & $\begin{array}{l}\text { c. } 1982 \\
\% \text { we1ght }\end{array}$ & $\begin{array}{l}\text { Feb.-Mar } \\
\% \text { numbers }\end{array}$ & $\begin{array}{l}\text { ch } 1983 \\
\text { \% we1ght }\end{array}$ & $\begin{array}{r}\text { May } \\
\text { \% numbers }\end{array}$ & $\begin{array}{l}1983 \\
\text { \% weight }\end{array}$ \\
\hline $\begin{array}{l}\text { SIPUNCUIA } \\
\text { Phascolion strombi }\end{array}$ & - & - & - & _ & 0.04 & $<0.01$ & 0.05 & 0.02 \\
\hline $\begin{array}{l}\text { GASTROPODA } \\
\text { M1tre11a d1ssimilis }\end{array}$ & - & - & - & - & 0.04 & 0.17 & - & - \\
\hline $\begin{array}{l}\text { BIVALVIA } \\
\text { Crenella glandula } \\
\frac{\text { Arct1ca }}{\text { 1slandica }} \\
\text { Cerastoderma p1nnulatum } \\
\text { Enis directus (R) }\end{array}$ & $\begin{array}{l}- \\
- \\
-\end{array}$ & $\begin{array}{l}- \\
\overline{-} \\
-\end{array}$ & $\begin{array}{l}- \\
-\end{array}$ & $\begin{array}{l}- \\
- \\
-\end{array}$ & $\begin{array}{l}- \\
- \\
0.07\end{array}$ & $\begin{array}{l}- \\
- \\
0.27\end{array}$ & $\begin{array}{l}0.05 \\
0.05 \\
0.05 \\
-\end{array}$ & $\begin{array}{c}<0.01 \\
<0.01 \\
0.79 \\
-\end{array}$ \\
\hline $\begin{array}{l}\text { CRUSTACEA } \\
\text { Copepoda (P) }\end{array}$ & 0.11 & 0.06 & - & - & - & - & - & - \\
\hline $\begin{array}{l}\text { Cumacea } \\
\frac{\text { Diastylis }}{\text { D1astylis }} \frac{\text { quadrispinosa }}{\text { sculpta }} \\
\frac{\text { Lamprops quadr1plicata }}{\text { Petalosarsia declivis }}\end{array}$ & $\begin{array}{l}0.06 \\
0.06 \\
- \\
-\end{array}$ & $\begin{array}{l}0.03 \\
0.05 \\
- \\
-\end{array}$ & $\begin{array}{l}- \\
0.04 \\
0.02 \\
0.04\end{array}$ & $\begin{array}{r}- \\
0.04 \\
0.01 \\
<0.01\end{array}$ & $\begin{array}{l}- \\
0.04 \\
- \\
0.07\end{array}$ & $\begin{array}{c}- \\
\overline{0.01} \\
\overline{0.01}\end{array}$ & $\begin{array}{l}0.09 \\
- \\
-\end{array}$ & $\begin{array}{l}0.05 \\
- \\
-\end{array}$ \\
\hline $\begin{array}{l}\text { Isopoda } \\
\text { C1rolana polita }\end{array}$ & - & - & - & - & - & - & 0.14 & 1.91 \\
\hline 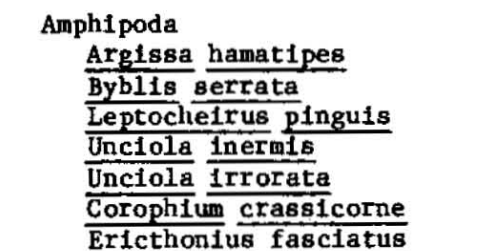 & $\begin{array}{c}- \\
- \\
- \\
17.92 \\
2.40 \\
- \\
71.38\end{array}$ & $\begin{array}{c}- \\
- \\
- \\
10.34 \\
1.47 \\
- \\
23.51\end{array}$ & $\begin{array}{r}0.02 \\
0.08 \\
0.02 \\
38.16 \\
12.43 \\
0.02 \\
45.00\end{array}$ & $\begin{array}{r}<0.01 \\
0.06 \\
0.01 \\
43.68 \\
21.19 \\
<\quad 0.01 \\
26.42\end{array}$ & $\begin{array}{r}0.04 \\
0.29 \\
0.04 \\
65.79 \\
5.76 \\
0.33 \\
23.57\end{array}$ & $\begin{array}{r}<0.01 \\
0.06 \\
0.01 \\
72.67 \\
9.56 \\
0.12 \\
8.80\end{array}$ & $\begin{array}{c}- \\
- \\
- \\
23.97 \\
0.74 \\
- \\
64.63\end{array}$ & $\begin{array}{c}- \\
- \\
17.85 \\
0.67 \\
- \\
19.46\end{array}$ \\
\hline
\end{tabular}




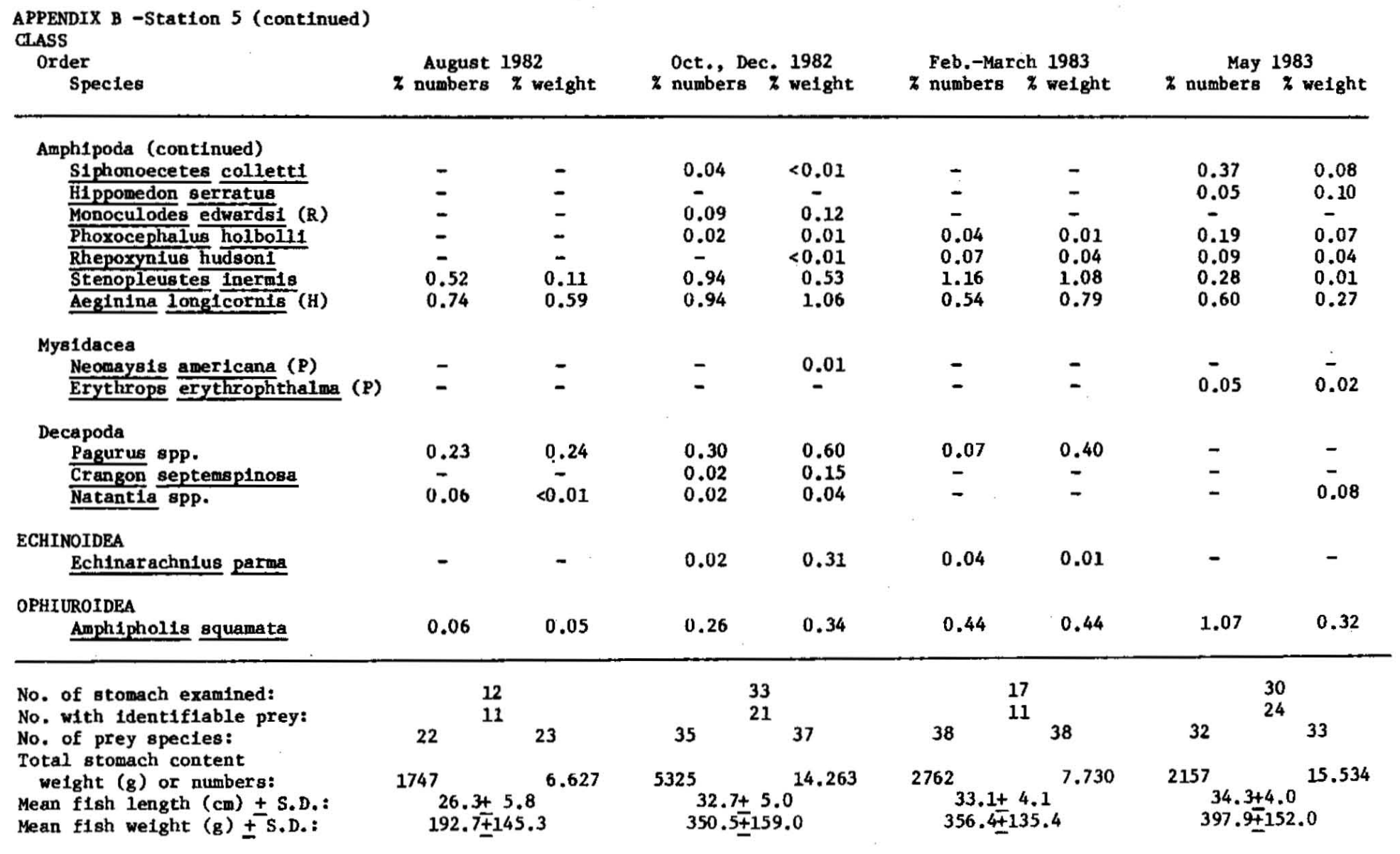


APPENDIX B. Yellowtail Flounder Stomach Contents Data - Station 10

\begin{tabular}{|c|c|c|c|c|c|c|c|c|}
\hline $\begin{array}{l}\text { Cl.ASS } \\
\text { Order } \\
\text { Specles }\end{array}$ & $\begin{array}{r}\text { August } \\
\% \text { numbers }\end{array}$ & $\begin{array}{l}1982 \\
\text { \% weight }\end{array}$ & \multicolumn{2}{|c|}{ Oct., Dec. 1982} & \multicolumn{2}{|c|}{ Feb.-March 1983} & \multicolumn{2}{|c|}{ May 1983} \\
\hline \multicolumn{9}{|l|}{ ANTHOZOA } \\
\hline Cerianthus borealig (R) & - & 0.02 & 6.95 & 71.03 & - & - & 0.81 & 30.30 \\
\hline \multicolumn{9}{|l|}{ POLYCHAETA } \\
\hline Ampharete arct1ca (R) & 4.03 & 0.56 & - & - & - & - & 0.10 & 0.07 \\
\hline Pherusa cf. falcata (R) & 0.08 & 0.01 & - & - & - & - & 0.20 & 0.38 \\
\hline Glycera dibranchiata & 0.23 & 0.51 & - & - & 1.14 & 1.42 & 0.10 & 1.00 \\
\hline Glycera $\frac{\text { n. sp. A }}{\text { n. }}$ & 0.08 & 0.02 & 0.53 & 0.02 & - & -42 & - & 1.00 \\
\hline Lumbrineris fragilis & 0.23 & 1.36 & - & - & - & - & 1.53 & 12.47 \\
\hline Nephtys bucera & 0.23 & 1.24 & 1.07 & 1.71 & - & - & 0.10 & 0.17 \\
\hline$\frac{\text { Nerels }}{\text { zonata }}(R)$ & - & - & 0.53 & 1.26 & - & - & $\simeq$ & - \\
\hline Ophelina acuminata & - & 0.14 & - & - & - & - & - & - \\
\hline Le1toscoloplos 8pp. juv. (R) & - & - & - & - & - & - & 0.10 & 0.65 \\
\hline Orbinia swant (R) & - & - & - & - & - & - & 0.20 & 2.65 \\
\hline Paraonis pygoenigmatica & 0.08 & $<0.01$ & - & - & - & - & - & - \\
\hline Polygord1us sp. A & 1.47 & $<0.01$ & - & - & - & - & - & - \\
\hline Chone Infundibuliformis (R) & 0.08 & 0.18 & - & - & - & - & - & - \\
\hline Scailbregma inflatum & 0.16 & 0.17 & - & - & 1.14 & 0.51 & - & - \\
\hline Sthene1a1s linicola & 1.09 & 0.59 & - & - & - & - & 2.03 & 6.11 \\
\hline Splophanes bombyx & 1.78 & 0.03 & - & - & - & - & - & - \\
\hline \multicolumn{9}{|l|}{ BIVALVIA } \\
\hline Arctica 1slandica & - & - & - & - & - & - & 0.10 & 0.14 \\
\hline Ens1s directus (R) & - & - & 1.60 & 0.87 & - & - & - & - \\
\hline Sp1sula solidissima & 1.01 & 0.21 & 1.07 & 0.58 & - & - & - & - \\
\hline$\frac{0 p}{\text { Tellina }} \frac{\text { tenella }}{\text { ten }}$ & 0.23 & 0.04 & - & - & - & - & - & - \\
\hline
\end{tabular}


APPENDIX B - Station 10 (continued)

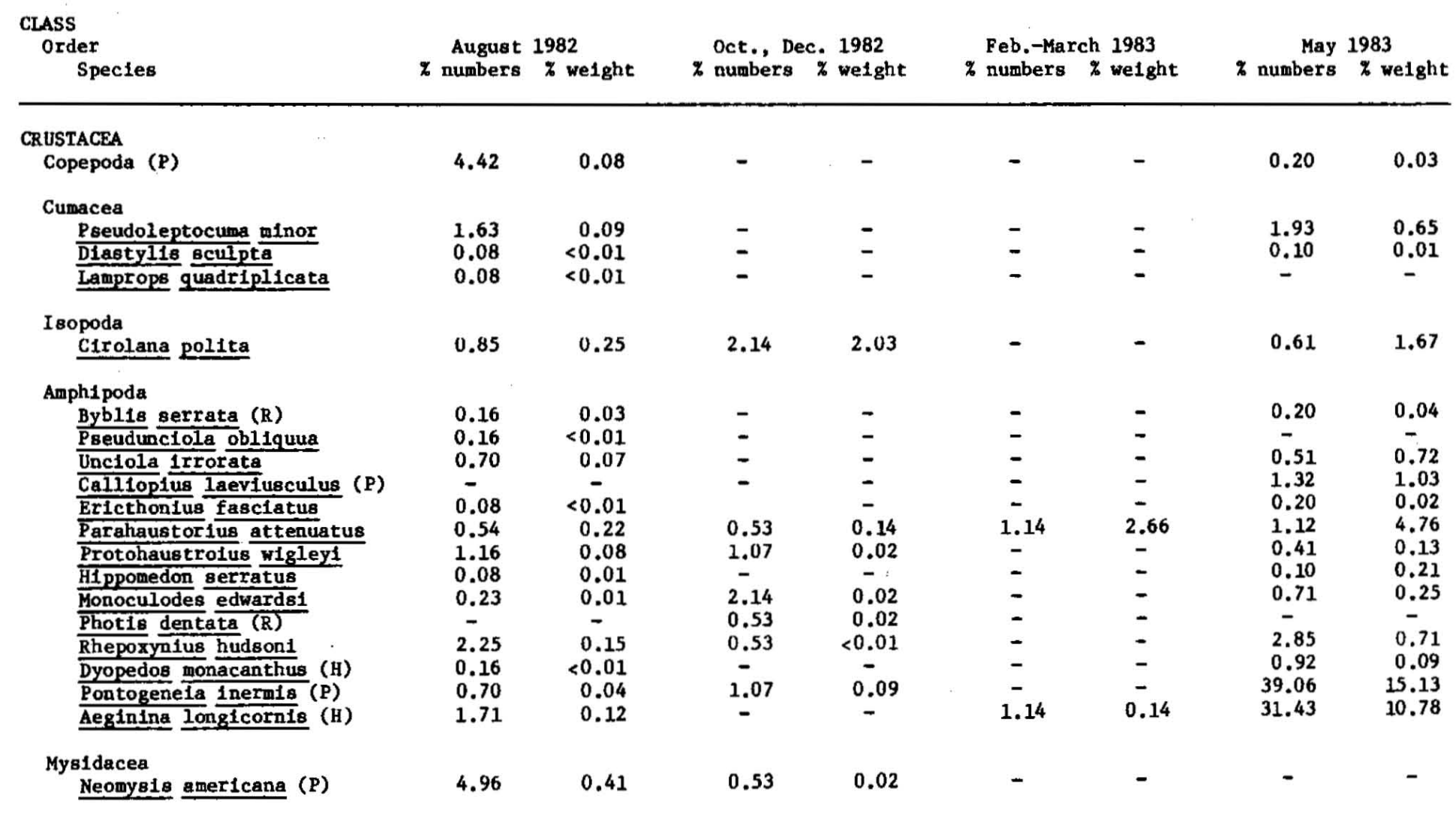


APPENDIX B - Station 10 (continued)

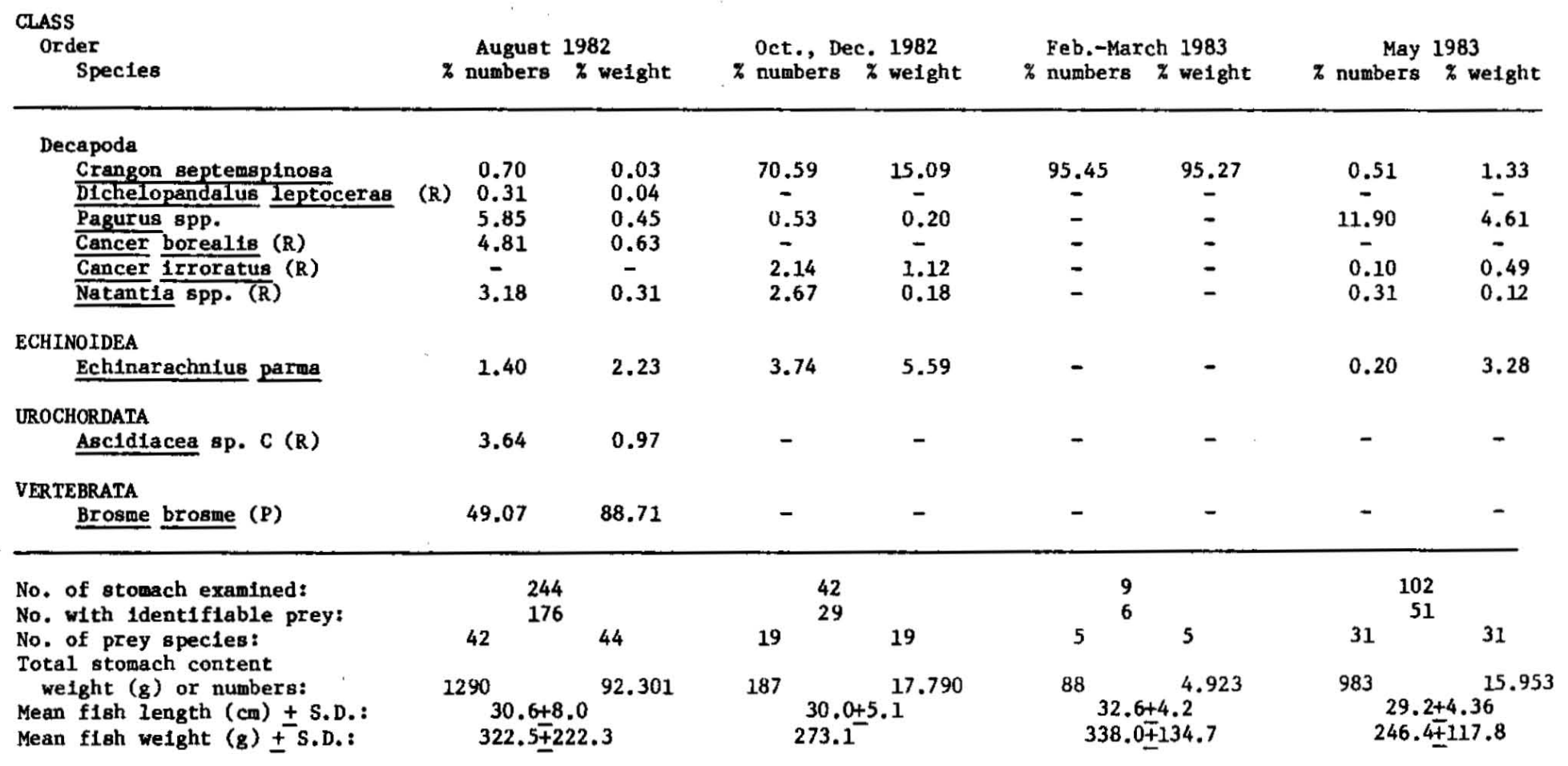


APPENDIX B. Yellowta1l Flounder Stomach Contents Data - Station 13 CLASS Order

August 1982

Oct., Dec. 1982

Feb.-March 1983

May 1983

Spectes

\% numbers \% weight

\% numbers \% weight

\% numbers \% we1ght

\% numbers \% weight

POLYCHAETA

Ampharete arctica

Anobothrus gracllis

Tharyx acutus

Tharyz annulosus

Tharyx dorsobranchialis

Tharyx marton1 (R)

Cossura 1ongocirrata

Brada villosa

Pherusa cf. falcata

G1ycera capitata (R)

Lumbrineris fraglils

Lumbriner1s impatiens

Lumbrineris $\mathbf{8 p . C}$

Nlnoe nigripes

Asych 15 biceps

hodine gractilior

glaophamus circinata (R)

Nephtys incisa (F)

Ophelina acuminata

Aricidea catherina

Aricidea longobranchiata

ArIc1dea neosuec1ca (R)

Aricidea quadrilobata

Aricidea suecica

Levinsenia gracilis

Eteone longa

Eucranta villosa

ermothoe extenuat

0riopsis sp. A. (R)

$\begin{array}{cccc}- & - & - & - \\ - & - & - & - \\ - & - & - & - \\ - & - & - & - \\ - & - & - & - \\ - & - & - & - \\ - & - & 1.90 & 4.88 \\ 9.09 & 26.28 & 0.95 & 11.10 \\ - & - & - & - \\ 18.18 & 2.44 & - & - \\ - & - & - & - \\ - & - & - & 2.63 \\ - & - & 13.33 & - \\ - & - & - & - \\ - & - & - & -95 \\ - & - & -.95 & 20.92 \\ 9.09 & 3.27 & - & - \\ - & - & - & - \\ - & - & - & - \\ - & - & - & - \\ - & - & - & -0.02 \\ - & - & -95 & - \\ - & - & - & - \\ - & - & - & - \\ - & - & - & - \\ - & - & - & - \\ & - & - & -\end{array}$

$\begin{array}{cccc}0.30 & 0.01 & 0.08 & 0.01 \\ 0.12 & 0.10 & 0.24 & 0.04 \\ 0.06 & 0.01 & 0.16 & 0.01 \\ 0.31 & 0.02 & - & - \\ 0.03 & <0.01 & 0.16 & <0.01 \\ 0.06 & <0.01 & - & - \\ 0.09 & <0.01 & 0.08 & <0.01 \\ 0.09 & 0.71 & 0.08 & 0.35 \\ 0.82 & 16.46 & 2.06 & 10.67 \\ 0.03 & <0.01 & - & - \\ & - & - & - \\ 2.44 & 0.60 & 4.91 & 0.81 \\ 0.03 & 0.01 & 0.16 & 0.02 \\ 5.31 & 2.35 & 12.59 & 5.40 \\ 0.03 & 0.11 & 0.08 & 0.38 \\ - & - & 0.32 & 0.36 \\ - & - & - & - \\ 1.07 & 29.52 & 0.16 & 12.50 \\ 0.03 & 0.10 & - & - \\ 0.40 & 0.03 & 1.03 & 0.02 \\ - & - & & \\ 0.03 & <0.01 & & <0.01 \\ - & - & 0.08 & <0.01 \\ 0.03 & <0.01 & 0.08 & 0.01 \\ 3.27 & 0.18 & 3.64 & 0.07 \\ 0.06 & 0.01 & - & - \\ - & - & 0.40 & 0.05 \\ - & - & 0.08 & <0.01 \\ - & - & 0.08 & <0.01\end{array}$


APPENDIX B - Station 13 (continued)

\begin{tabular}{|c|c|c|c|c|c|c|c|c|}
\hline $\begin{array}{l}\text { CL.ASS } \\
\text { Order } \\
\quad \text { Specles }\end{array}$ & $\begin{array}{r}\text { August } \\
\text { \% numbers }\end{array}$ & $\begin{array}{l}1982 \\
\text { \% weight }\end{array}$ & \multicolumn{2}{|c|}{$\begin{array}{l}\text { Oct., Dec, } 1982 \\
\text { \% numbers \% we1ght }\end{array}$} & \multicolumn{2}{|c|}{ Feb.-March 1983} & \multicolumn{2}{|c|}{ May 1983} \\
\hline \multicolumn{9}{|l|}{ POLYCHAETA (continued) } \\
\hline Chone duner 1 & - & - & 10.48 & 1.77 & 1.37 & 1.09 & 1.27 & 0.72 \\
\hline Chone Infundibuliformis & 27.27 & 9.90 & 21.90 & 43.39 & 4.37 & 29.50 & 23.75 & 57.90 \\
\hline Euchone Incolor & - & - & - & - & 0.03 & $<0.01$ & 0.08 & $<0.01$ \\
\hline Prionospio steenstrupl & - & - & - & - & - & - & 0.08 & 0.01 \\
\hline Sp1o 11m1cola & - & - & - & - & - & - & 0.08 & 0.04 \\
\hline Sternaspis scutate (R) & - & - & - & - & 0.03 & 0.87 & 0.08 & 0.24 \\
\hline Terebellides stroemi & - & - & - & - & 0.03 & 0.02 & 0.71 & 0.17 \\
\hline \multicolumn{9}{|l|}{ BIVALVIA } \\
\hline Nucula prox1ma & - & - & - & - & 0.21 & 0.06 & - & - \\
\hline \multicolumn{9}{|l|}{ CRUSTACEA } \\
\hline Copepoda (P) & - & $\boldsymbol{\top}$ & - & & 0.03 & 0.01 & 0.16 & 0.01 \\
\hline \multicolumn{9}{|l|}{ Cumacea } \\
\hline Diastylis sculpta & - & - & - & - & 0.06 & 0.04 & 0.16 & 0.04 \\
\hline Eudorella pusilla & - & - & - & - & 0.18 & 0.03 & 0.32 & 0.02 \\
\hline \multicolumn{9}{|l|}{ Isopoda } \\
\hline Edotea triloba & - & - & 0.95 & 0.75 & - & - & 0.16 & 0.04 \\
\hline \multicolumn{9}{|l|}{ Amphipoda } \\
\hline Arg1ssa hamatipes & - & - & - & - & 0.18 & 0.04 & 0.32 & 0.04 \\
\hline Ampe118ca agassiz & 18.18 & 0.46 & 40.95 & 5.95 & 13.62 & 4.15 & 41.81 & 8.92 \\
\hline Leptoche1rus p1nguis & - & - & - & - & 0.06 & 0.17 & 0.16 & 0.16 \\
\hline Unciola 1rrorata & - & - & - & - & - & - & 0.24 & 0.12 \\
\hline Erlchthonlus fasclatus & - & - & - & - & 0.15 & 0.04 & 0.32 & 0.05 \\
\hline Orchomene $8 \mathrm{p} . \mathrm{A}(\mathrm{R})$ & - & - & - & - & 0.06 & 0.02 & - & - \\
\hline Casco bigelowi & 9.09 & 6.09 & - & - & 0.03 & 0.21 & 0.08 & 0.16 \\
\hline Phot18 pollex & - & - & - & - & 0.31 & 0.01 & 0.08 & 0.01 \\
\hline
\end{tabular}


APPENDIX B - Station 13 (continued)

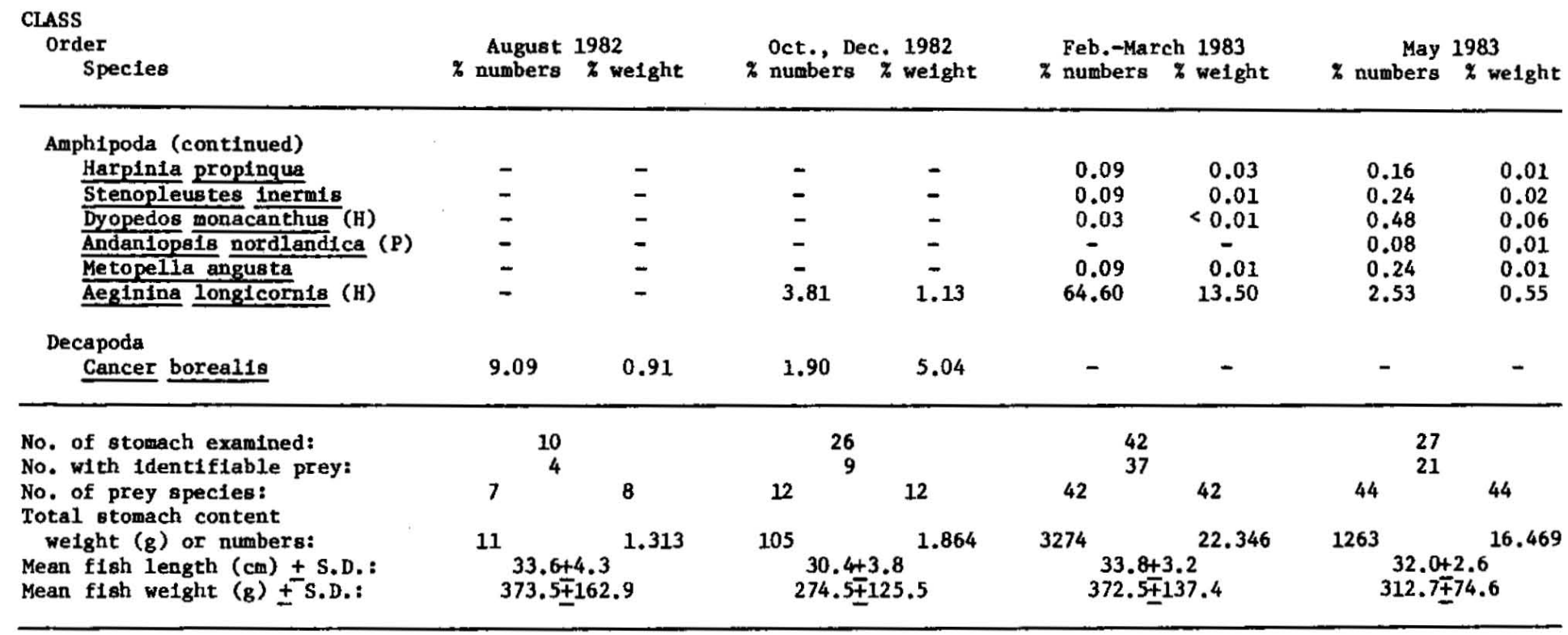

(F) - fragments

(H) - lives on hydroids and bryozoans

(P) - pelagic

(R) - absent from benthic samples at this station

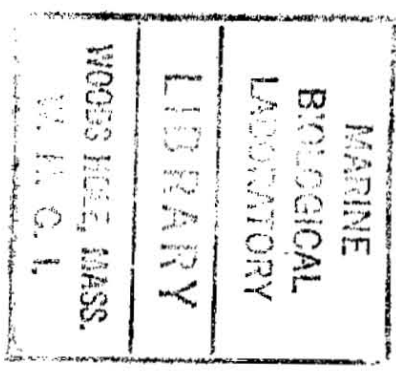


Append1x C. Chone 1nfundibuliformis production (wet weight) at Station 13 from July 1982 to July 1983.

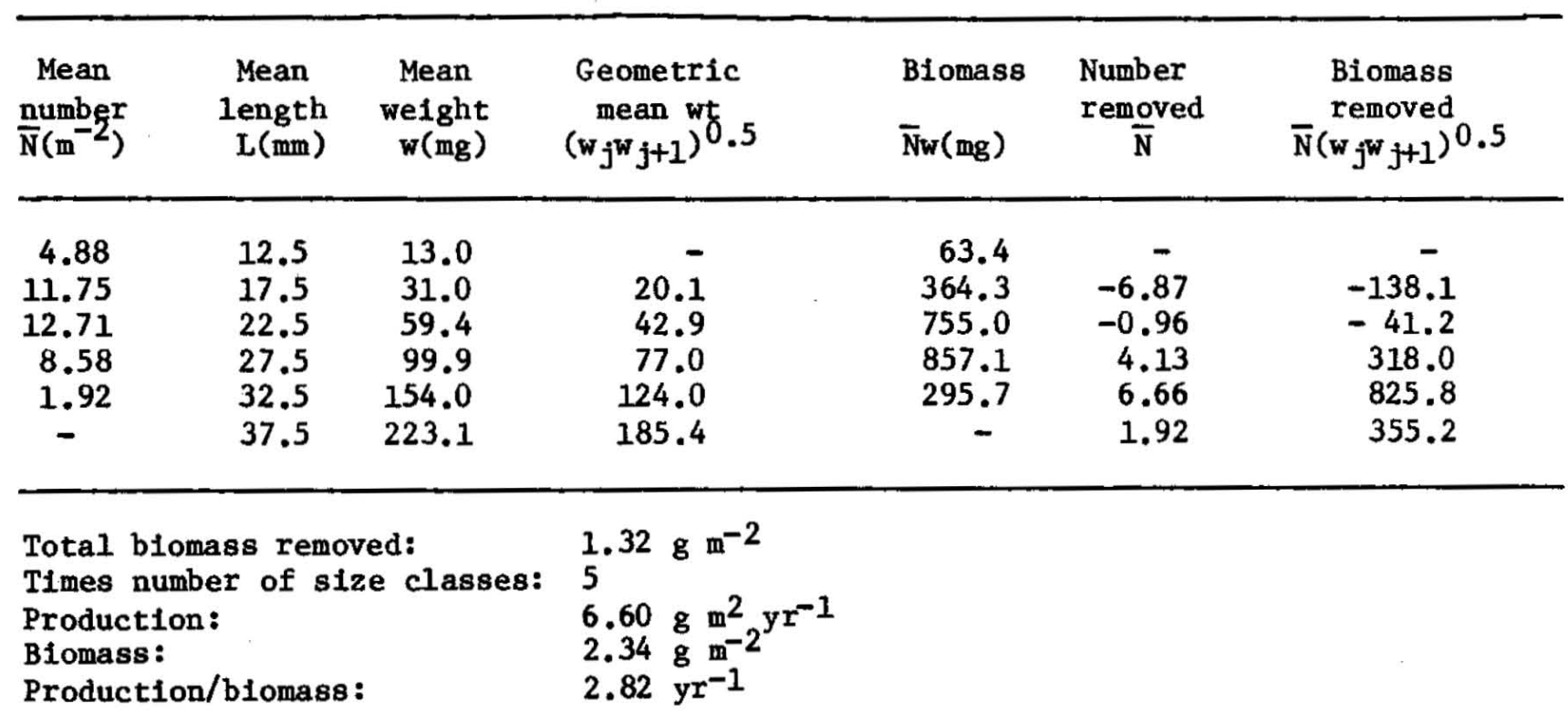


About the Author

Jeremy Steven Collle was born in a blizzard in Winnipeg, Manitoba, Canada, on 27 April 1958. When he was five years old his family moved to London, Ontario; in $1976 \mathrm{Mr}$. Collie graduated London Central High School. He attended one year at the University of Guelph, after which he was matriculated at the Unfversity of York, in York, England. In July $1980 \mathrm{Mr}$. Collie recelved a Bachelor of Science in Blology with First Class Honours from York.

In September 1980 Jeremy Collie entered the Massachusetts Institute of Technology / Woods Hole Oceanographic Institution Joint Program in oceanography. This thesis culminates Mr. Collie's doctoral work in biological oceanography.

Mr. Collie is married to a non-oceanographer who is so cute that she prefers to remain anonymous. They live in Vancouver, British Columbia, where since September 1985 Jeremy Collie has held a position at the University of British Columbia. He pursues his research interests and those of his employer at the Institute of Animal Resource Ecology. As well, Jeremy Collie continues with his lifelong favorite activities: skifing, salling, and other outdoor pursults, most especially running. 